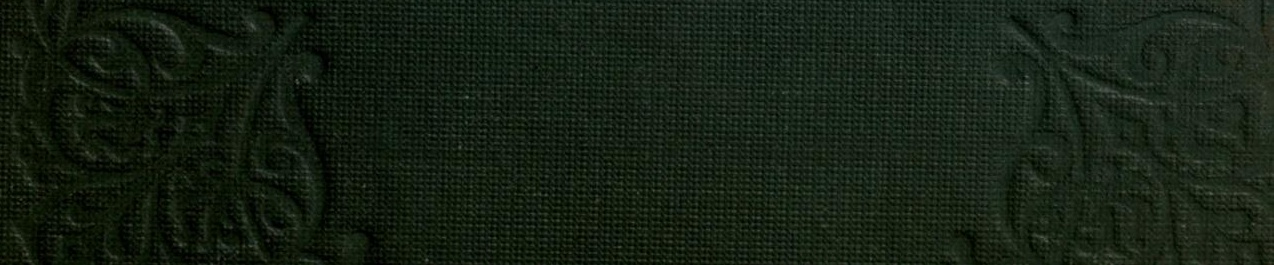



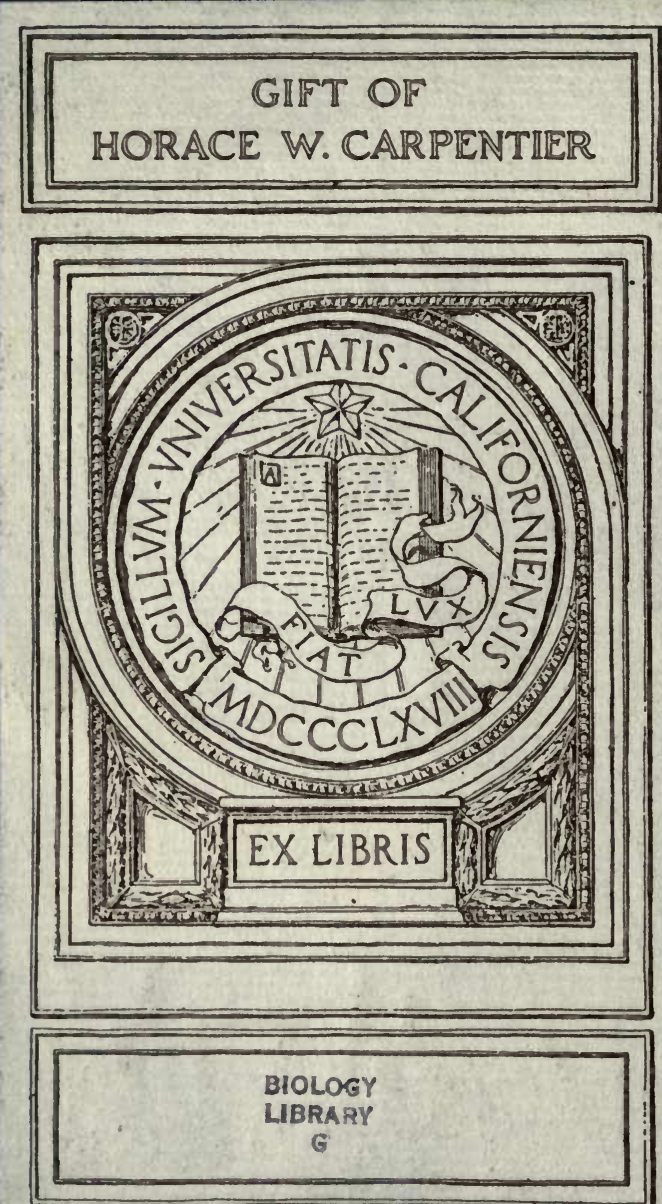

BHOLOGY G 



\section{BIRDS' NESTING}

wx

\section{N D I A.}

A CALENDAR OF THE BREEDING SEASONS, AND A POPULAR GUIDE TO THE HABITS AND HAUNTS OF BIRDS.

\section{ILLUSTRATED.}

By Captain G. F. L. MARShALL, R.E., F.z.S., AND MEMBER OF 7 HE BRITISH \& INDIAN ORNITHOLOGICAL UNIONS.

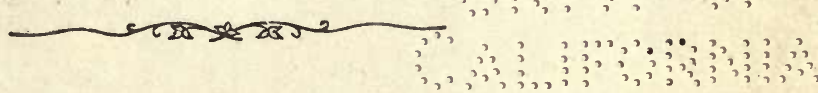

Ceralutta:

PUBLISHED BY THE CALCUTTA CENTRAL PRESS CO., 5, COUNCIL HOUSE STREET. 
CALCUTta :

CALCUTTA CENTRAL PRESS COMPANY, LIMITED,

5, COUNCIL HOUSE STREET.

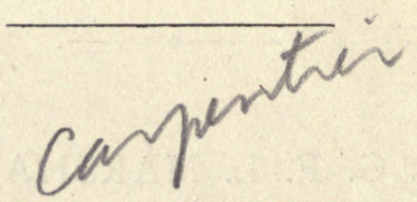

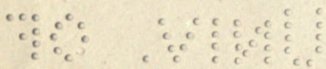

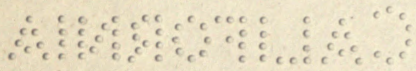




\section{CONTENTS.}

\section{PART I.}

Preface

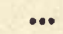

...

CHAPTER I.-Introductory, breeding seasons and hints on birds' nesting

CHAPTER II.-Habits and haunts of birds, with general description of types of eggs $\quad$.. $\quad \ldots \quad$... ${ }^{*} \quad \ldots$

\section{PART II.}

INDEX. - List of birds that are known to breed in India, with duration of breeding season for each species tabulated ...

\section{PART III.}

CALENDAR showing the birds of which the eggs may be looked for during each month of the year; with description of nest and the situation where usually placed

\begin{tabular}{|c|c|c|c|c|c|}
\hline$J_{A N U A R Y}$ & ... & ... & ... & $\ldots$ & ... \\
\hline Febrdary & $\ldots$ & ... & ... & ... & ... \\
\hline MARCH & $\ldots$ & ... & ... & ... & $\ldots$ \\
\hline APRIL & ... & ... & ... & ... & ... \\
\hline MAY & $\ldots$ & ... & ... & ... & ... \\
\hline JUNE & $\ldots$ & $\cdots$ & ... & $\ldots$ & $\ldots$ \\
\hline JULX & ... & $\ldots$ & $\cdots$ & $\ldots$ & $\ldots$ \\
\hline AUGUST & $\ldots$ & ... & $\ldots$ & $\ldots$ & $\ldots$ \\
\hline Septembei & & $\ldots$ & $\ldots$ & $\ldots$ & $\ldots$ \\
\hline ОстовеR & $\cdots$ & $\ldots$ & ... & $\ldots$ & $\ldots$ \\
\hline November & & $\ldots$ & ... & $\ldots$ & ... \\
\hline DeCEMBER & & ... & ... & $\ldots$ & $\ldots$ \\
\hline
\end{tabular}





\section{LIST OF ILLUSTRATIONS.}

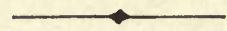

Page.

Taking the Broadbill's Nest

FRONTISPIECE.

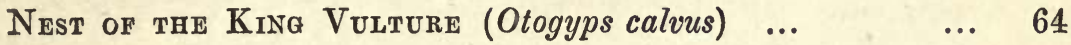

Nest of the thick-billed Flowerpecker (Piprisoma agile) ... 69

Nest of the Red-headed Tit (Egithaliscus erythrocephalus) 76

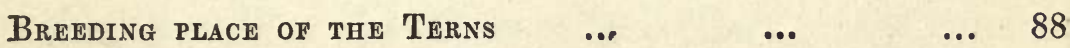

Nest of the white-throated Fantail (Leucocerca fuscoventris) 107

Nest of the White-browed W ARble? (Abrornis albosuperciliaris) 130

Nest of the yellow-throated Broadbill(Psarisomus dalhousia) 149

Nest of the Whistling Teal (Dendrocygna arcuata) _.. 161

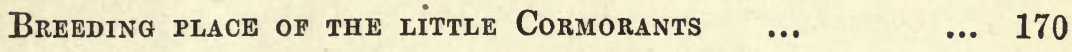

Nest of the YeLLOW-BELLIEd FANTAII (Chelidorhynx hypoxantha) 174

Nest of the bRown fish OWL (Ketupa ceylonensis) $\quad \ldots \quad 177$

Nest OF THe PURPLe HoNeysucKer (Arachnechthra asiatica) ... 180 


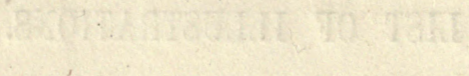

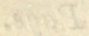

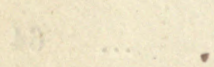

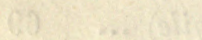

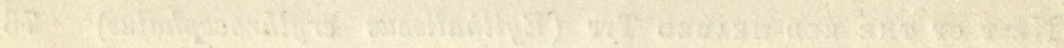

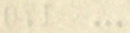

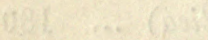

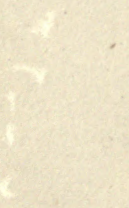




\section{PREFACE.}

TEN years ago when beginning to make a collection of birds' eggs in this country, I was struck by the diversity in the breeding seasons, and the want of any guide to assist the beginner in his researches. Since then I have kept a continuous record of my observations, and, with the intention of eventually publishing them, I have endeavoured to gather together, as far as possible, the recorded experiences of others; and this little book is the result. Many friends have kindly placed their collections at my disposal, and for a great deal of the information regarding the rarer birds, I am indebted to the courtesy of Mr. A. O. Hume, in permitting the use of extracts from a draft of his book on "Indian Birds' Nests and Eggs," which has as yet only been printed for private circulation : to this source are due the valuable observations from Sikkim by Mr. Gammie; from Hansi (Punjab), the Central Provinces, and Bundelkhund by Mr. Blewitt; from the Nilgiris by Miss Cockburn and Messrs. Davidson and Wait, and by many others from various parts of India, while the information from Bengal is chiefly due to Mr. Parker. Of private collections from which notes have been taken those of Captains Cock and C. H. T. Marshall, and of Mr. W. E. Brooks, were the most important, and to all these gentlemen my thanks are due.

The notes from upper India are comparatively full and complete, but as regards Eastern and Peninsular India they are as yet very meagre, more especially from the latter. A good deal of new information has been collected since the manuscript of this book was put in hand, and more is being accumulated month by month; but the knowledge already gained is valuable as far as it goes, and believing that it is better that what is known should be made at once available to the public, rather than that indefinite delay should be made for fuller detail, I offer no further apology for the incompleteness of the record.

This book will not in any way supplant the carefully detailed work which Mr. Hume is compiling on the nidification of. Indian birds, but it will supplement it by abstracting, in a convenient form, certain points 
of information, and so facilitate the direction of research into the proper channels. Mr. Hume's work, when published, and, it is to be hoped, it soon will be, should be in the hands of every lover of Natural History in this country.

No details are here given as to the materials and apparatus necessary in forming a collection and in preparing and preserving specimens : those who wish to commence collections of eggs or of skins of birds, will find all information as to details in Mr. Hume's "I NDIAN OrNithologicaL Collector's VADE-Mecum," a most useful little book published by the Calcutta Central Press Company (5, Council House Street, Calcutta), and priced one rupee: but with reference to collections of eggs, it is necessary to repeat here that eggs are scientifically worthless as specimens, unless the species of bird to which they belong has been accurately ascertained; and to do this effectually it is necessary for all except the most practised observers that the skin of the parent bird should be in all cases obtained and preserved.

If egg collectors, into whose hands this book may come, would kindly communicate to me any notes they may make from their orn experience in correction or extension of the information now recorded, it would confer a great obligation on me, and enable me, in case a second edition may be required, to render it more complete and satisfactory than I am able to do in the present case.

The list of birds in Part II serves as an index, the order of arrangement followed by Jerdon is adopted, and having ascertained from this list the months in which any particular bird breeds, the further details required will be found on reference to the lists for those months. 


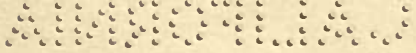

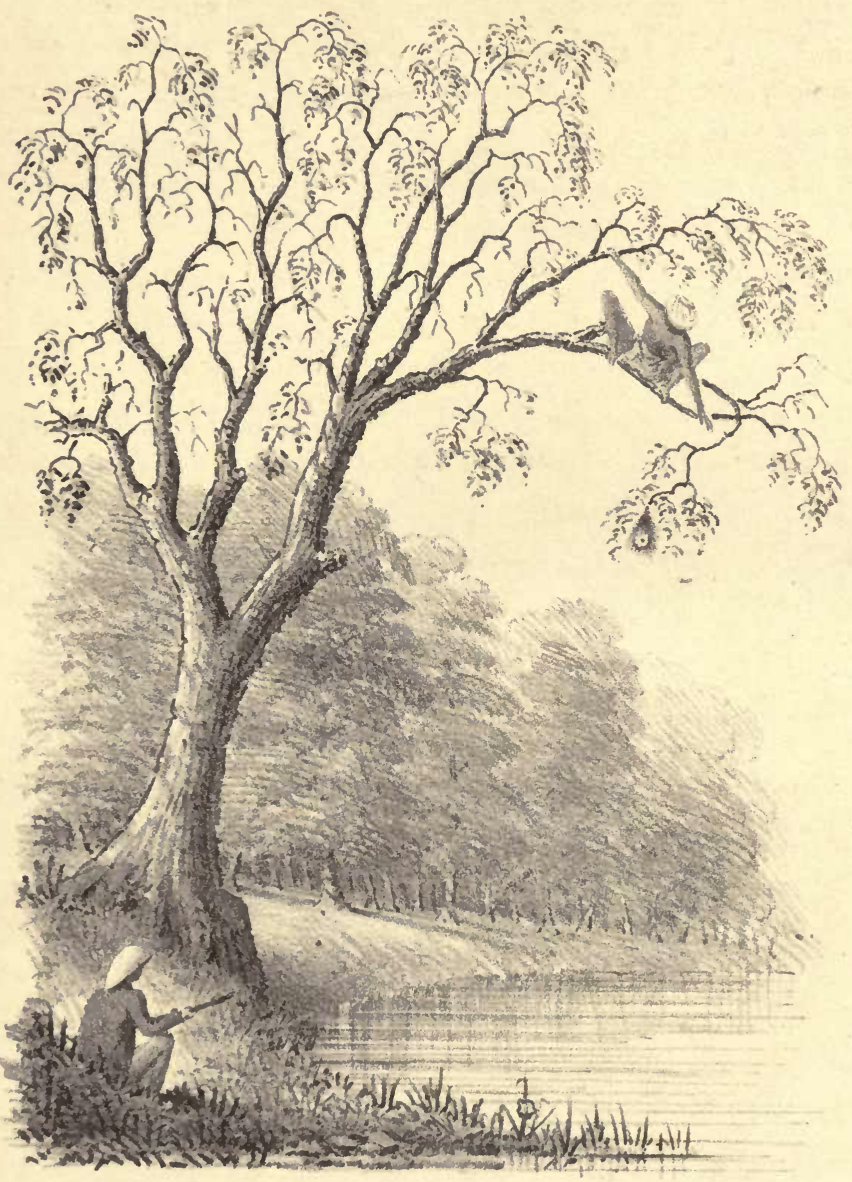

MAREMALL DEL.

TAKING THE BROADBILLS NEST, 


\section{BIRDS' NESTING IN INDIA.}

CH A P T E R I.

\section{INTRODUCTORY; BREEDING SEASONS AND HINTS ON BIRDS' NESTING.}

BIRDs' nesting has gained in civilised countries a very evil reputation, in many cases unfortunately only too well deserved, by the wanton cruelty with which it is attended; and it must be stated clearly to begin with, that the publication of this book is not intended in any way to encourage the idle and foolish destruction of birds, nor to countenance the wholesale robbing of young and eggs from nests, which has brought the very name of birds' nester into discredit, and has changed what should be, and is, if properly carried on, a healthy and instructive pursuit into a deserved reproach.

That the collecting of birds' eggs may be done without cruelty is not to be doubted by any one who has devoted time and thought to the question. Few birds attach any importance to fresh eggs, it is only as the process of incubation progresses, and the maternal instincts are developed, that any grave anxiety is shown by the parent birds when the eggs are approached; even at this stage many birds will forsale the nest at once if the eggs are touched; and when the eggs are quite fresh, the simple fact of the nest being touched, or even the detection by the parent bird that the nest has been discovered, is sometimes enough to lead to its desertion: in such cases the taking of the eggs is clearly not followed by any distress to the parent birds. Not many years ago I used to feel very much more strongly on this point than I do now; the pain at robbing a nest used quite to embitter the joy of discovering a prize; but it happened on one occasion, during a march through the Bolandshahr district, that 
I found a nest of a kind I had long sought in vain, the whistling teal (Dendrocygna arcuata). These curious little ducks perch in trees and lay their eggs in nests made of sticks and twigs in trees. The nest was in a babul tree, at the edge of a large swamp, about ten feet from the ground; and standing on a bank close by, I could see both parent birds seated side by side on the nest, with their little heads laid lovingly together, and their soft eyes watching me with no signs of dread. A severe mental struggle followed. My desire to get the eggs turned the scale, and I determined on shooting both the parent birds so as to leave no desolate mourner. I startled them from the nest, and as they flew off, fired right and left, killed the drake, but alas missed the duck. The deed was done, and there was nothing left but to take the egg which I did with a saddened heart and walked on to my camp three miles distant. All that day the memory of the poor little solitary duck haunted me. I could not get it out of my mind, and the next morning I determined to return to the spot, though it took me six miles out of my way, and put an end to the misery of the unhappy survivor by shooting her. On reaching the place, there I found her, seated on her empty nest, the scene of the previous day's calamity, seated indeed, but not alone, she was accompanied, and no doubt successfully cheered by another drake that had already aspired to the place in her affections vacated by her unfortunate partner only the day before. In this case the nest contained only a single egg which was quite fresh, the usual number laid for hatching being from seven to ten.

The behaviour is, lowever, very different when the little family arrangements are further developed. I once found the nest of a goldencrested wren, with eight eggs in it. The eggs were new to me at the time, and as I was anxious to find out accurately to what bird they belonged, I set a snare by the nest, and in a few minutes caught and killed the hen bird, and tinen taking the nest I sat down to pack it, and the eggs and the little bird to convey them safely away. While I was engaged on this, the cock bird appeared and soon perceived the disaster that had happened to his home, his plaintive chirping was most piteous to hear, and I hurriedly moved away, but there was no escaping, the poor little thing followed me incessantly, keeping pace with me and flitting from tree to tree, till passing out of the pine wood $I$ got into open-treeless ground, and there, unable to trust his frail little wings to the long flight, and fearing to alight on the open common, he fell back, and to my great relief his cries of woo were soon lost to hearing. The eggs were so hard set in this case that I was unable to preserve even one 
of them, and that day's work I have ever regretted. It cannot of course be known how long the little bird mourned his loss, or what his end was, but on the other hand no one can doubt that the sorrow for the time was real and deep.

When the eggs are hatched, and the helpless young lie in the nest dependant solely on the parent birds for food and life, the maternal instincts are of course quicker and more deep-seated, and many anecdotes could be told of the devotion of birds to their young, and of their courage and ingenuity in defending them. I will only mention one instance which occurred to a friend of mine. A nest of the golden oriole, often known as the mangp bird (Oriolus kundoo), had been found in the garden containing young, and was taken and brought into the house with the intention of rearing the young for the cage. The nest was placed by an open window, and there was discovered by the parent birds. They took charge of it as if nothing had happened, coming fearlessly into the verandah and feeding the young all day long. After a few days the nest was removed to another house more than half a mile distant, and still the parent birds followed it, tended it in the new situation, and eventually I believe reared up the young and carried them off as soon as they were able to fly. The golden oriole is a shy retiring bird, and for it to overcome so far its dread of man shows a very high order of parental affection.

One more instance, perhaps the most curious of all, I must give before passing on to resume my subject. The heroine this time being a kite (Milvus govinda). Kites are not attractive birds, except for the wonderful grace of their flight, and it is hard to imagine a tender heart beneath their fierce but treacherous and withal cowardly exteriors. In the month of January in lower Bengal when with the kites the breeding season is at its height, a solitary female, over whom the instincts of the season evidently had their sway, but who from some cause or other was unprovided with a nest or eggs, appropriated an empty pill-box that had been thrown on to the roof of a portice, and gathering some sticks and straws round it in the corner of the roof to serve as a nest, she commenced and carried on with admirable perseverance a forlorn attempt to hatch it. When approached and driven from her place she would return to defend the beloved treasure dashing fiercely at the intruder. How long it would have taken before her hopes of welcoming a young kite out of the pill-box would have been finally abandoned was not proved, for a beavy storm of rain reduced it to a pulp, and in its place the egg of a domestic fowl was put down, and on that the kite now joined 
by a male kite who keeps careful guard over her, is still sitting. The eggs will be hatched in a few days, and the life of the young chick, which will probably be short and adventurous, will commence.*

It is not essential to the pursuit of natural historythat collections of eggs or skins should be made; but the act of collecting is the simplest and readiest if not the only certain way of rendering the eye sufficiently familiar with the appearance of birds to enable any one to recoguise and distinguish at a distance the various kinds one from another, and for this reason the making of a collection is very advisable. The interest in the subject so far from ceasing would even increase when the collection was formed and the knowledge gained in the act of collecting remains. Experience proves that, after the acquisition of specimens is no longer desired, there is a pleasure in intelligently watching and noting the habits of birds and animals in life, the intensity of which grows in the minds of all true lovers of nature, just in proportion as its gratification is no longer encumbered with the necessity for taking the lives of harmless and beautiful creatures.

The duties of an Englishman in India frequently entail a great deal of out-of-door life, much of which is in many instances solitary. To such, the need of a pursuit to interest the mind and divert it in leisure hours from the groove of official routine is very great, and to this end the study of natural history is pre-eminently adapted. Few countries offer greater inducements or better opportunities for it than India does, and its pursuit not only affords occupation and in terest both in-doors and out-of-doors, but it is also accessible to all and necessitates no more costly apparatus than is within the means of every official Englishman. The habits of close observation which it fosters are especially useful ; and the careful record of personal observations supplies the much-needed data, without which general laws cannot be discussed or deduced. As to the healthy interest it developes in life, those who have experienced it will testify. A country which to others may seem a dreary waste is often to the naturalist a very mine of wealth, a ride across it, or a march through it, becomes replete with interest and enjoyment ; and it is earnestly hoped that, on perusing these pages, some of the many Englishmen scattered over India in solitary places may be induced to take up the study of ornithology, and find in it a new and growing interest which will while away many a pleasant hour.

* This curious instance of aberrant instinct was pointed out to me by Col. Tucker, R.E., on whose house the event occurred and indeed is still occurring. 
A knowledge of the habits and seasons of birds is especially useful to sportsmen who seldom have the time for ascertaining the breeding seasons of game birds by personal observation, and in consequence of the want of this information many of our Indian game birds are slaughtered while they have eggs or young chicks, even by men who would be the first to condemn the deed if it were done wittingly. In England long experience has rendered every one familiar with such things, but in this country the seasons are known only to a few. At present no means exist for others of readily ascertaining them, and sportsmen are helpless in the matter. A case in point quite recently came under my observation. A large bag of the likh florikin (Sypheotides auritus) had been made in the very height of the breeding season, but no idea that such was the case had ever entered the head of the man (a true sportsman) who had shot them, and he was quite ignorant of the extent of the damage unconsciously inflicted. I feel sure that the publication of any facts that will aid in preventing this misdirection of sport will be welcomed by all, and if each will supplement the existing knowledge of the subject by carefully recording his own personal experiences, we should in a few years have sufficient materials accumulated for a complete record of the breeding seasons, and the way wonld be paved at all events for an unwritten law, known and honoured by all sportsmen for the observation of close seasons, and then, but not till then, India will become, as it ought to be, equal to the best country in the world for a day's small game shooting. The occasional holiday with a gun, so looked forward to by many, would no longer result in a weary trudge with a nearly empty bag at the end, as is now not unfrequently the case; and partridge-shooting would then afford as good sport as snipeshooting does at present, but which is in the latter case entirely owing to the fact that the snipe by removing themselves en masse to other countries inaccessible to sportsmen, when the breeding season comes round, are able to carry on their domestic arrangements in peace and security.

But to return to the birds' nesting, the real reason why the difficulties arise out here, is the irregularity in season of breeding in tropical climates as compared with temperate climates. In the latter, breeding among birds is almost universally confined to the spring and early summer months. On coming out to India, people naturally assume that the rule holds good out here, which is only very partially the case, and the first difficulty that besets a beginner in collecting birds' eggs in this 
country is the absence of any information on this point. At first, search for nests is only made in the spring and summer months, but in the course of time eggs are found incidentally in other months, both earlier and later, and it gradually becomes evident that hours of fruitless search and watching of birds, to trace from their movements where their nests are concealed have been thrown away, which a little experience would have saved by teaching that the breeding season were eitiner already over or had not yet begun, or in some instances even never would begin in that part of the country. It is to answer at all events partially this question, when do the birds breed? that these notes are published. The question is now being answered in full detail for each bird by Mr. Hume's book already referred to in the preface, and this little book will give a review of the year month by month, indicating the direction in which search can at any given time be profitably carried on.

In dealing with a limited area, either tropical or temperate, it would be comparatively easy to furnish a complete guide on this point in a small compass; but with a large country like India, including every variety of climate from the eternal snows of the alpine Himalayas to the unvarying round of heat in the southern peninsular on the one hand, and from the arid deserts of Sind to the humid forests of Assam on the other hand. It is a task of much difficulty to afford full details in a single book. The area dealt with is bounded by the main ridge of the Himalayas on the north; the Suliman range and the Arabian sea on the west; by the Indian ocean on the south; and by the bay of Bengal and Assam on the east. Climate has by far the largest influence in determining the breeding period with birds, and thus over so large an area it is clear that great variations must occur at different points. Speaking generally, it may be assumed that the colder the climate, the more uniformly will the breeding season be confined to the warmer months; and the hotter and less variable the climate, the more irregularly will the breeding season be spread throughout the year. Among hot climates the drier the climate, the more the breeding season inclines to the summer and monsoon months; while in damp tropical climates the winter months are more prolific in proportion; but in India, excluding the Himalayas, there is no place where eggs of some species may not be obtained in every mouth of the year.

The fewest number of kinds of birds known to breed in this country 
in any one month is twenty-eight, and that month is November; and further research will probably show that this number is under the mark. In May four hundred kinds of birds are known to breed, and the number is probably little short of five hundred. Of the twelve hundred or so species found in this country, the breeding of about six hundred has already been ascertained, of the remainder many are migratory and do not breed in this country at all, but there still remains a wide field for discovery, the great bar to further progress being the deadly character of some parts of the country at certain seasons of the year. The great majority of the birds, the breeding of which is yet unknown, frequent swamps or dense forests, and probably breed at seasons of the year when exploration is not only attended with extreme discomfort, but with serious risk of life. Some few kinds, such as hawk owls (Ninox) and some of the goat suckers (Caprimulgide) and others, though they breed in accessible and healthy localities, escape observation by their shy and retiring habits.

In every part of India the vultures and many of the large eagles breed during the cold season, the most notable exception is the breeding of the Indian tawny eagle ( $A$. vindhyana), the spotted eagle $(A$. navia), and the long-legged eagle ( $A$. hastata) in the height of the hot weather in moist localities, such as Saharunpoor, the Terais, and Calcutta, but in other parts these species too conform to the general rule. Many of the owls, especially the large ones, breed in the winter, and almost all the others breed in the early spring. The water birds breed during the rainy season. In July and August, in the country affected by the southwest monsoon, and in December in those parts of the south-east coast which are under the influence of the north-east monsoon. In some places the herons are known to breed in the spring, this has been ascertained in Oudh and also at Saugor, but it is unusual. The small warblers also of all kinds breed chiefly, though not without exception, during the rainy season. For the rest the season varies with locality.

In the Himalayas the chief season is April, May, and June, but many eggs may be found in February and March; and also in July. All the finches breed late, chiefly in July in the higher ranges. From August to November birds' nesting does not repay the labor and fatigue of walking in the hills, few, if any, eggs are to be found, and only definite search after particular kinds, which there may be good reason to believe are then breeding, should be made. In December and January the big vultures and eagles have eggs, and their eyries should be sought for. 
The seasons for any particular kinds that may be spread throughout the whole range of the Himalayas are usually somewhat earlier in the eastern, and later in the western portion.

In the hills of south India the season is much the same as in the Himalayas, but it begins earlier, and ends later. There too a second or autumn brood is frequently hatshed, while in the Himalayas, with birds that have two broods, the first is usually in March, and the second in June. In the southern hills, the ranges being less lofty and easily accessible to and from the plains, birds' nesting may be carried on with more or less success over a much longer period by extending the rambles to the forests at the foot of the hills from time to time.

In the plains, where the tropical extremes of temperature occur, the season never ends, every month of the year yields a fair harvest. Some individual species breed all the year round, and where some leave off, others begin, so that the birds' nester may be always fully employed. In the dry parts of the plains, more especially towards the north and west, the autumn months are comparatively barren seasons, the end of the cold weather, and throughout the hot weather and rains being the most prolific periods.

In searching for birds' nests the great secret of success after all is patience and perseverance, and when this is backed by keen eyesight and a knowledge of the habits of birds, success is certain. When the time of breeding is known, the way is cleared to a great extent; but when the time for any particular species is only to be found out by observation, search may be guided by noting the breeding times of closely allied kinds of birds. If the breeding of one species is known, it may generally be inferred, though it is not always the case, that other species of that genus will breed about the same time in that locality. An exception to this is found among the crows, the common crow (Corvus impudicus) breeding in the upper provinces in June, while the raven ( $C$. corax) and the corby ( $C$. culmenatus) both breed in those parts during the winter. Other exceptions will occur to all who have collected eggs in this country, but the rule generally offers a fair guide.

When this method leads to no results, the simplest way with common species is to shoot a specimen from time to time and ascertain by dissection whether breeding is in progress or not. Of course, if the birds are rare, this method cannot be carried out; for it defeats its own object, and watching must be resorted to. With birds in which the sexes differ in plumage, the disappearance of the hen birds, while the 
cocks are still to be seen about, leads to the inference that the former are in all probability sitting on eggs somerwhere close by, and if watched, the male bird may be seen to carry food to the female, and thus lead to the discovery of the nest. Some birds put on handsome plumes or tufts of feathers as the breeding season approaches, which indicates when search for the eggs should be made. If watched closely, many kinds of birds may be detected pairing; or, in the case of such as build nests, they may be seen carrying bits of stick or straw, or wool or feathers in their bills to the tree or hole where they are preparing their little home. This latter of course leads not only to the knowledge of the breeding season, but also what is more to the point to the discovery of the nest. Some birds that are widely spread over the country breed in one locality or another nearly throughout the year. Some again breed nearly throughout the year in the same locality. Among these latter may be mentioned the striated bush babbler (Chattarhoea caudata), the pin-tailed munia (Munia malabarica), the blackbellied finch lark (Pyrrhalauda grisea), the common sandgrouse (Pterocles exustus), and all the commonest doves in the plains.

To ensure success in discovering nests to any extent, it must be repeated that close and persevering search is necessary, many nests and sometimes those of the rarest birds are found accidentally, but even in these cases the finding generally results from a habit of keeping a watch on the morements of birds, and without labor and perseverance no great results can be looked for in this or in any other pursuit. With birds that sit close the nest itself must be searched for; and likely spots must be beaten, or otherwise disturbed, to cause the bird to fly off; but in many cases this is not necessary, as birds often quit their nests on the first signs of the approach of man. In forest country if the trees are too numerous, or the underwood is too thick to allow of complete search, it is best to keep a sharp look-out some thirty yards ahead of where you are walking to catch sight of the birds as they rapidly and often silently flit from the nest and reveal its situation. In this manuer $I$ found in one morning nests of the small billed mountain thrush (Oreocincla dauma), the dusky bush thrush (Geocichla unicolor), the black-throated jay (Garrulus lanceolatus), and several others in the course of a quick ride through a secluded forest. It is sometimes advantageous to sit quite still for a time and watch, but as a rule moving about gives the best chance. One morning in the hot weather I had sat down to light my pipe at the foot of a tall clump 
of surkerry grass, when a little wren warbler (Prinia stewarti) flew up with a straw in its mouth, suddenly caught sight of me and alighting on a twig close by, looked at me in evident astonishment without moving for two or three seconds, then opening its bill and dropping the straw it gave a most melancholy chee-e-ep. I looked round, and just at my back, fortunately uninjured, was the nest neatly woven in among the stalks of the grass about a foot above the ground; it was unfinished, and I left it in peace and moved away. Tapping the trunks of trees with a stick in passing is a good plan, as it will generally put a bird up off a nest that would otherwise sit close and escape observation; but even with those species that lay in deep holes in trees, a sound of approaching footsteps is often enough to rouse the bird. I once found the nest of a speckled piculet (Vivia innominata), in this way, seating myself on a bank to rest for a few moments under a tree, and looking up among the branches, a head of a little bird protruded from a tiny hole caught my eye. The bird had been roused by the sound of my approaching footsteps, and was looking out to see the cause. The hole which was pierced in the wood of an old trunk at some distance from the ground was so small that I could only put one finger into the entrance, and was almost invisible until the eye was guided to it. To find nests of this description, such as woodpeckers and barbets, the easiest way is by listening carefully in the woods in the early part of the breeding season when the tapping noise made by the birds in digging out the holes with their bills guides the eye to their position.

To find nests in bushes and trees when the birds are close sitters, it is sometimes a good plan to disturb the birds by beating the foliage; but by far the best way is to select the most likely localities where birds are most numerous and carefully search every bush. In open country, with scanty jungle and few trees, every bush and tree should be searched, especially where birds are abundant. Large isolated trees which are so marked a feature in the plains are very favorite resorts, and most of them are more or less tenanted in the season. If the country is quite open, or if the jungle is like the common "beri" thorn jungle, too low and thick to search systematically, better results will be got on horseback than on foot, and in such situations many nests may be found while cantering about on a sure-footed pony. When the country is quite bare of vegetation, as in some plains and fallow lands, or even low stubble, a look-out should be kept well ahead for plovers or sandgrouse and other birds which creep quietly away from their eggs 
long before you can get near them. If little bushes or tufts of grass are scattered about here and there, the pony should be guided to pass close by them; and if a lark or pipit or other bird of similar habits should happen to have a nest under the shelter of one of them, the bird will rise sometimes almost at the horse's feet. For thick low jungle where the riding plan fails, the place should be beaten or dragged with a rope, which latter will make even quail, which are exceedingly close sitters, rise from their eggs. The object of the rapid approach on horseback is to startle the bird and make it rise hurriedly, as otherwise it would creep quietly away unobserved to the other side of the bush.

With gregarious birds the matter is more simple, the breeding haunts may easily be found in most cases, except when the powers of flight are very great as with the spinetails and swiftlets, by noting where they tend to congregate when the proper season arrives. When once the breeding ground is known, it is easy to find the individual nests.

A plan tried by Captain Cock of nailing up a sheepskin to a tree, and watching with binoculars the birds that came to take the wool, was found very successful with tits and some small birds, but experience is the best guide in all cases; and with these general remarks I must have the reader to arrange his own course of action in each case. 


\section{H A P T E R I I.}

\section{HABITS AND HAUNTS OF BIRDS, WITH GENERAL DESCRIPTION OF TYPES OF EGGS.}

Vultures, (Ologyps, Gyps, Percnopteron, Gypaetus).-Build a

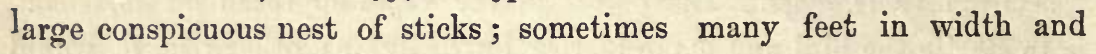
depth ; generally a huge solitary tree is chosen for the purpose, and the nest is difficult to reach, indeed often nearly inaccessible. The usual number of eggs laid in each nest is one; two is the greatest number ever laid, and that only by a few species; so that a good collection of the eggs of these birds requires a great deal of difficult climbing and perseverance. Some kinds, the king vulture and the "roc," lay pure white eggs. Of other kinds the eggs are more or less spotted, those of the "scavenger" and bearded vulture being often very richly coloured. The great brown vulture (Vultur monachus) only occurs here in the cold weather, all the other vultures are permanent residents, some breeding wherever they are found, others congregating at particular spots when the time for nest building arrives.

Falcons, (Falco.)-Of the eight species of true falcons which are found in India, only three are known to breed here; the rest are cold weather visitants migrating to north and west in the summer. Of the three which remain, one, the laggar falcon ( $F$.juggur) is found in dry plains; the two others, the "shahin" ( $F$. perigrinator) and the black cap falcon ( $F$. atriceps) affect wooded and rugged country. The nest, though large, is generally well concealed. From three to six eggs are laid, which are always well marked, sometimes very richly coloured.

Hobbies, (Hypotriorchis).-Nothing is known of their breeding in this country. The European hobby: $(H$. subbuteo $)$ is a rather rare winter visitant. The Indian hobby (H. severus) is a permanent resident in the eastern Himalayas, where its nest will probably be found in high trees in forest tracts.

Merlins, (Lithofalco).-The merlin of Europe (L. esalon) is a rare cold weather visitant. The red-headed merlin ( $L$. chicquera) is very common, it is a permanent resident, and chiefly found in mango groves. The nests are well concealed in thick foliage, and the eggs are of the same type as those of the true falcons. 
Kestrils, (Tinnunculus, Erythropus.)-The common kestril ( $T$. alaudarius) is found all over the country in the cold weather, but retires to the mountain ranges to breed. Of the breeding of the other two kestrils ( $E$. cenchris and $E$. vespertinus) very little is known. The former is said to breed in the Nilgiris, and the latter may probably breed in the Himalayas. The eggs are richly coloured.

Pigmy falcons, (Hierax).-O Of these beautiful little birds very little is known. Only one kind is found in India, in the extreme northeast. They feed on insects and frequent forests. They do not appear to be migratory.

Hawks, (Astur, Lophospiza, Micronisus, Accipiter).-The six species known in India are all permanent residents, though in the cold weather some of them wander far from their breeding haunts. Of the besra sparrow hawk (A. virgatus), nothing is known as to its breeding. They affect wooded localities and often fly high. The eggs of Astur and Micronisus are pale blue or grey unspotted. The sparrow hawks lay boldly blotched eggs. One only ( $M$. badius) breeds in the plains; the others all breed in mountain ranges and temperate climates.

Eagles, (Aquila, Neopus).-The golden eagle (A. chrysaetus) is said to breed in the alpine Himalayas, making its nest on cliffs; but no eggs have been taken as yet. The black eagle ( $N$. malaiensis) also breeds on cliffs; the other resident eagles breed on trees. All the true eagles are more or less migratory. The great tawny eagle ( $A$. fulvescens vera or $A$. ncevioides) and the barred imperial eagle (A. bifasciata) leave the country altogether in the breeding season. Eagles frequent open or wooded places, perching on high trees and soaring in search of prey. The nests are conspicuous, and they lay two or sometimes one egg; white with a few spots or blotches.

Hawk eagles, (Nisaetus, Limnaetus, Spizaetus).-Bonelli's eagle (N. bonellii) frequents open plains as well as wooded hills. The other hawk eagles are confined to forest tracts, and from the unhealthiness of the woods at the breeding time, but few of their nests are taken. They perch in trees with thick foliage and keep a good deal out of sight. They have a loud rather musical call which often leads to their detection. Their eggs generally two in number are sparingly spotted or streaked. They are partially migratory, but probably all breed within Indian limits.

Serpent eagles, (Circaetus, Spilornis).-The short-toed eagle ( $C$. gallicus) is a permanent resident and frequents dry open plains, perch- 
ing on isolated trees. It lays a single white egg. The crested serpent eagles (Spilornis) are found in forests and well-watered tracts. S. cheela breeds in the warm sub-Himalayan valleys. The nest is placed about half way up a tree near water, and the eggs two in number are slightly spotted. They migrate to the well-watered plains in the cold weather. The others are probably permanent residents were found.

Fishing eagles, (Pandion, Polioctus, Halicetus).-These are always found in the neighbourhood of water. They build enormous nests of sticks on high trees. The osprey ( $P$. halicetus) probably breeds in this country, but the eggs have not as yet been taken. They are very handsomely blotched. The other fishing eagles are permanent residents where they occur, and lay unspotted white eggs.

Buzzards, (Buteo, Archibuteo, Poliornis).-Of the true buzzards (Buteo) only one, the long-legged buzzard (B. canescens) is known to breed in India. It breeds in the far north-west. The others are confined to the mountains of India and affect well-wooded slopes. Their eggs are boldly.blotched. Of the genus Archibuteo nothing is known. The two species that occur in India (A. hemiptolopus and A. strophiatus) are sorne of the rarest birds in collections. The white-eyed buzzard ( $P$. teesa), the only representative of the genus Poliornis in India proper, is very common throughout the plains, and a permanent resident everywhere. Its eggs, three in number, are unspotted as a rule.

Harriers, (Circus).-Are cold weather visitants to India, retiring north and west to breed. One the marsh harrier (Coeruginosus) may prossibly breed in a few localities, but the majority of them leave the country. They breed on the ground in marshy tracts and lay bluish unspotted eggss.

Kites, (Haliastur, Milvus, Baza, Elanus).-The brahminy kite (H. indus) is found in all well-watered districts, and is a permanent resident where found. Of the breeding of the crested kite (Baza lophotes) nothing is known. It is wide spread in its distribution, but rare everywhere. The black-winged kite, ( $E$. melanopterus) is common in well-wooded districts. All the kites, except the larger Indian kite (M. major) which migrates to the plains in the cold weather, appear to be stationary in their habits. They all build on trees and lay handsomely blotched eggs.

Owls, (Strix, Scelostrix, Phodilus, Bulacca, Otus, Ascalaphia, IInhua, Bubo, Nyctea, Ketupa, Ephialtes, Athene, Heteroglaux, 
Glaucidium.)-A great number of owls are found in India, most of them are permanent residents. The short-eared owls (Olus) are the only truly migratory ones. They all lay pure white eggs of a rounded shape. The grass owl (Scelostrix candida) lays on the ground in grass. The rock-horned owl (Ascalaphia bengalensis) lays on shady ledges of banks. Some of the wood owls (Bulacca) lay occasionally on ledges of rocks. The screech owl (Strix indica) and the spotted owlet (Athene brama) lay sometimes in buildings or deserted wells, but the place par excellence for finding owls' eggs is in natural hollows in decayed trees. Some of the larger owls which would find holes in any ordinary tree rather tight quarters lay in hollows at the bifurcations of the trunks of large trees. Owls are seldom seen, owing to their nocturnal habits, but some species or other is to be found in every part of India. Some of them live in houses inhabited by man, but the great bulk of them frequent wellwooded districts away from human habitations.

Hawk owls, (Ninox). - Nothing is known of the nidification of these curious birds. They affect wooded localties, and are more widely spread than is usually thought. They appear at twilight, perching on conspicuous dead boughs.

Swallows, (Hirundo).-Are very widely spread. They are often gregarious and generally found near water over the surface of which they feed. They occur throughout India, and breed much near human habitations. Their nests, of whatever shape, are all made of pellets of clay, fixed against a building or rock generally with a soft lining. The eggs are pure white in some, but spotted in others. The common swallow (H. rustica) is migratory. A few pairs only remain to breed in the Himalayas. All the others are permanent residents where found, except perhaps $H$. daurica which breeds in the Himalayas only, but is found in the plains in winter.

Martins, (Cotyle, Chelidon).-Are very locally spread through India. the sand martins (Cotyle) are found near large rivers. The crag martins (Cotyle) and the house martins (Chelidon) chiefly affect rocky country, and of the breeding of these latter very little is known. They are all more or less gregarious. The crag martins lay spotted eggs. The sand martins lay pure white eggs. They are partially migratory.

Spine tails, (Acanthylis).-Of the breeding of the spine tails nothing is known, their amazing powers of flight, and the great distances they traverse in a day, render cbservation of their habits almost 
impossible. They probably breed in company against precipitous rocks.

Swifts, (Cypselus.)-The breeding of the larger swifts is difficult to ascertain from the same reason as in the case of the spine tails. They fly with great ease and swiftness, and though not, as far as is known, migratory; in the true sense of the word, they wander far and come and go irregularly. The palm swifts are much more local and do not wander far from their breeding haunts. The eggs of all swifts are pure white and very elongated. They are all more or less gregarious breeders.

Swiftlets, (Collocalia.)-Three kinds of swiftlets breed in India. They are gregarious, with great powers of flight, and wander far. They breed on rocks. Some of the species make the "edible nests" so highly valued by the Chinese. Their eggs like those of the swifts are pure white and very elongated.

Tree swifts, (Dendrocheledon).-Only one species is found in India, and that confined to forests and very local. The egr (only one is laid) is pure white and elongated.

Frogmouths, (Otothrix, Batrachostomus).-Are confined to forests and very local, little is known of them. They probably breed in holes or on stumps and lay white eggs.

Goatsuckers, (Caprimulgus.)-These birds are widely spread, but each species is comparatively local. They are crepuscular in their habits, and frequent wooded or waste jungly land. They are permanent residents wherever found, and lay two elongated eggs, beautifully marked with pink or brown and salmon colour, on the bare ground or on a few dead leaves. They lie exceedingly close, not rising till they catch your eye. The beds of shady nullahs, ravines, at roots of trees, or in dense underwood, are the spots where they usually deposit their egris, but they are sometimes laid by a sprig in an open field; and to find them careful and persevering search is necessary. Of $C$. macrourus and C. mahrattensis, the eggs have not yet been found. Though not gregarious, one or two nests may sometimes be found very near each other.

Trogons, (Harpactes).-Are not migratory. They frequent dense forests and lay pure white eggs in holes in decayed trees. Only two kinds are found in India, and they are very local.

Beeeaters, (Merops, Nyctiornis).-Are found all over India. 
Some frequent forests, and some open plains, but as a rule they are seldom found far from water, except the common bee eater (M. viridis), which is found everywhere in the plains. They make no nest, and lay very round pure white eggs in deep holes in banks or in level ground. Sometimes old rat holes are used, but often they excavate for themselves. They are permanent residents, and the breeding of all, except the blue-ruffed bee eater ( $N$. athertoni), is well known. They are generally, though not always, gregarious and breed in colonies.

Rollers, (Coracias, Eurystomus).-Lay round white eggs in holes in decayed trees. They are not migratory as a rule, though they sometimes wander in the cold season far from their breeding haunts. The common roller ( $C$. indica), the "jay" of Englishmen in India, often breeds about houses. It is a well-known and conspicuous bird.

Kingfishers, (Pelargopsis, Halcyon, Ceyx, Todirnmphus, Alcedo, Ceryle).-Are essentially non-migratory. Wherever they are found they breed. They lay round white eggs in deep holes in banks, making no nest. Many species are found in India, but most of them are very local; and partly owing to their rarity, partly owing to the unhealthiness of the localities, they affect during the breeding season. The nests of only a few species have as yet been discovered in this country. The kingfishers in India all belong to genera, which keep near water and breed in holes in banks. Some genera belonging to other countries inhabit forests, and lay their eggs in holes in decayed trees. Here, though banks of rivers or canals are by far the most approved localities, instances have occurred of eggrs being found in holes in the sides of wells, in banks of ponds, and even in mud walls in a village.

Broadbills, (Psarisomus, Serilophus.)-The nidification of these birds is little known. They appear generally to build a globular or pear-shaped nest, ${ }^{*}$ hanging from the tips of boughs, and lay white eggs. Only two species occur ( $P$. dalhousice and $C$. rubropygia), both confined to the Eastern Himalayas, and both rather rare, though permanent residents. They affect oak forests and keep to the tops of trees.

Hornbills, (Homraius, Rhyticeros, Hydrocissa, Meniceros, Tockus, Aceros).- These are the "toucans" of Englishmen in India. They inhabit forests or wooded. conntry; and where they occur are permanent residents. They all nestle in holes in decayed trees gecerally at a considerable height from the ground. The entrance to the hole is

* See frontispiece. 
more or less plastered up after the female has entered, and the eggrs are white.

Parrots, (Palcoornis, Loriculus).-These occur throughout India some local, some widely spread, but all where they occur are permanent residents. They lay pure white eggs in holes in trees, generally they use a natural hollow, but sometimes they cut the entrance bole themselves, always choosing a tree decayed internally. The nest holes are often at a considerable height from the ground. They are gregarious when not breeding, and often a number of nests may be found in the same tree. They affect cultivation and open wooded country.

Woodpeckers, (Picus, Hypopicus, Yungipicus, Hemicircus, Chrysocolaptes, Muelleripicus, Gecinus, Chrysophlegma, Venilia, Gecinulus, Micropternus, Brachypternus, Chrysonotus).-There are a great number of species in India. Only two species are widely spread, the yellow-fronted woodpecker (Picus mahrattensis) and the common gold-back woodpecker (Brachypternus aurantius). The rest are local and confined to particular parts of India. They are as a rule only found in well-wooded districts. They all lay pure white eggs, and deposit them in holes in trees which they cut for themselves with a neat circular orifice.* The nest holes are always on the under-sides of boughs, or in perpendicular trunks to keep out rainwater. Woodpeckers are not migratory. They breed wherever they are found.

Piculets, (Vivia, Sacia).-Only two species occur in India, and these are confined to the Himalayas. In habits they exactly resemble woodpeckers, and lay white eggs in artificial holes in trees. They are not migatory.

Wrynecks, (Yunx).-One species, the common wryneck (Y.torquila) is common in the plains in the cold weather, but it migrates in the spring. It is said to breed in Kashmir, but no details are recorded. They nestle in holes in decayed trees and lay pure white eggs.

Honey guides, (Indicator).-One species is found though extremely rarely, and nothing is known of its habits.

Barbets, (Megalcema, Xantholoema).-Many species occur in India. They closely resemble woodpeckers in their habits, but they feed on fruit. They are non-migratory, breeding wherever they are found. They usually inhabit forests or weli-wooded country, lay pure white eggs, and de-

* Mr. Gammie has recently discovered that in Sikkim the bay woodpeckers (Micropternus) muke their nest holes in black ants' nests attached to trees, a most remarkable fact. 
posit them in holes which they cut fort hemselves in trees. They usually select a decayed tree, and the circular orifice pierced, they occupy the natural cavity in the centre of the trunk or bough.

Cuckoos, (Cuculus, Hierococcyx, Polyphasia, Surniculus, Chrysococcyx, Coocystes, Eudynamis).-All these birds are migratory more or less, and parasitic in their habits. They appear for breeding purposes in the spring in the hills, and in the rains in the plains, and lay their eggs in other birds' nests, selecting, according to circumstances, the bird most likely to prove useful in rearing their young for them. One of the hawk cuckoos ( $H$. sparverioides) is said to build its own nest in the Nilgiris, but this requires confirmation.

Ground cuckoos, (Zanclostomus, Centropus, Taccocua).-These birds are somewhat locally distributed; they chiefly inhabit dense jungle and thickets, and where they occur are permanent residents. They build massive stick nests often domed over, in thick cover, and lay white eggs, rather chalky in texture.

Spider-hunters, (Arachnothera).-These are a Malayan form, only two species extending to India. The nest of the big spider-hunter (A. magna) is a very neat massive deep cup, sewn to a leaf of the plantain tree, and the eggs are deep greyish brown.

Honeysuckers, (OEthopyga, Leptocoma, Arachnechthra.)-One species, the purple honeysucker ( $A$. asiatica), is spread throughout India. The other species, and there are many, are very local. The greater number confined to the Himalayas. They build a beautiful little pearshaped hanging nest, with a side entrance, overhung by a fringe, and lay two much speckled eggs. They are partially migratory and frequent warm valleys and jungles.

Flower-peckers, (Dicaum, Piprisoma, Myzanthe, Pachyglossa). - These birds are generally local and are not migratory. The nest is a beautiful little purse-shaped structure of a delicate felt-like substance hung not by a point but by an edge from a bough. The eggs are white in some species and spotted in others. They affect well-wooded localities, and often keep to the tops of high trees for feeding; though the nests are as often as not quite low down. The last two genera are only found in the eastern Himalayas.

Tree-creepers, (Certhia; Salpornis.)-The true tree-creepers (Certhia) are confined to the Himalayas where they are permanent residents. The nests are high up in trees behind crevices in bark and 
exceedingly difficult to find. The eggs are spotted. Of the spotted grey creeper (Salpornis spilonota) nothing is known. It is found in many localities, but nowhere common.

Wall-creepers, (Tichodroma).-Only one species occurs in India. It breeds in the Himalayas at 3,000 to 5,000 feet altitude, descending to the foot of the hills in the cold weather. The nest is slight, placed in a crevice in a rock.

Nuthatches, (Sitta, Dendrophila.)-These are all permanent residents where they occur. They are found in forests or well-wooded tracts. They make their nests in hollows in decayed trees, lining the hole with feathers, wool, or moss, and closing up the entrance with a stiff gummy substance, till only a tiny circular orifice is left. The holes are often near the ground, but sometimes very high up in large trees. The eggs are spotted rather boldly.

Hoopoes, (Upupa.)-The common hoopoe (U. epops) migrates to the plains in the cold weather, but breeds only in the north-west Himalayas. The Indian hoopoe ( $U$.nigripennis) is a permanent resident throughout the country. They nestle in holes in trees or buildings, lining the hole with a few feathers and leaves. They are domestic in their habits, often breeding about human dwellings. The eggs are greenish or brownish grey.

Shrikes, (Lanius).-Butcher birds or shrikes are permanent residents where they occur. They usually place their nest in the fork of a thick bush, but sometimes they wedge it up against the trunk of a tree, or even place it on a dead stump. The eggs are typically whitish, with a thick ring of spots near the larger end; but sometimes the whole egg is more or less spotted. Shrikes generally frequent open country and avoid forests. The brown shrikes are migratory and leave upper India in the spring.

Wood shrikes, (Tephrodornis).-The nests of the woodshrikes are small and very neatly made, usually placed in forks high up in trees and difficult to detect. The birds are not migratory, but the breeding of only one species, the common woodshrike ( $T$. ponticeriana), is known. Its eggs are very much like miniatures of the true shrikes.

Pied shrikes, (Hemipus.)-These birds are local and frequent hilly country. Very little is known as to their habits.

Cuckoo shrikes, (Volvocivora, Graucalus.)-These, like the woodshrikes, are permanent residents where they occur; but the nests 
are very difficult to find. They are small, neatly made, placed high up, and the outside is assimilated in appearance to the bark of the tree they are on. The eggs are boldly streaked and very handsome.

Minivets, (Pericrocotus).-Are almost always found in forests or well-wooded districts. They are gregarious during the cold weather, and some of them are migratory, but all the kinds that occur in India breed in this country. The nest is beautifully built, almost like a tumbler, with perpendicular sides, and placed on a horizontal branch high up. They are very difficult to find. The eggs are well spotted.

Drongo shrikes, (Dicrurus, Buchanga, Chaptia, Bhringa, Edolius, Dissemurus, Chibia).-Are almost entirely confined to forest tracts, with the exception of the common drongo shrike or "king crow" (D. albirictus), which is found every where. They are not migratory, though some of the hills species ascend to higher elevations as the weather gets warmer; and the white-bellied king crow (D. ccerulescens) seem to disappear from the plains in the breeding season, but of its habits very little is known. They all make a loose basket work saucer-shaped nest of roots wedged into a horizontal fork at the end of a bough often at a considerable height from the ground. The common king crow (D. albirictus) sometimes lays pure white eggs, but the typical colour in this family is white, with a few claret or brown spots.

Swallow shrikes, (Artamus).-Are very local and little is known of their habits. They are generally found in clearings in forests, and are probably permanent residents.

Flycatchers, (Tchitria, Myiagra, Leucocerca, Chelidorhynx, Cryptolopha, Hemicheliuion, Alseonax, Ochromela, Eumyias, Cyornis, Muscicapula, Nitidula, Niltava, Anthipes, Siphia, Erythrosterna).-The habits of this group show many variations. As a rule, flycatchers are to be found in forests and retired glens; but they also sometimes frequent gardens and orchards. Probably, all the Indian species breed within the limits of this country. The only doubtful ones being the robin flycatchers (Erythrosterna). Most of the flycatchers migrate to the plains in greater or less numbers during the cold weather. Out in the open plains the white-browed fan-tail ( $L$. aureola) is the only widely distributed permanent resident. The paradise flycatcher (T. paradisii), the black-naped azure flycatcher ( $M$. azurea), and the white-throated fan-tail (L. fuscoventris) breed in some of the moister 
and better wooded districts. Some of the blue red-breasts (Cyornis) breed in the plains of south India. All the others breed in the bills, and the greatest number breed in the Himalayas. Their nests are all ingenious. Some of them most beautiful little structures, seldom at any great height from the ground, and often resting on it. The eggs are in all cases prettily marked and spotted.

Wrens, (Tesia, Pnoopyga, Troglodytes, Rimator).-Are only found in the Himalayas within the Indian limits. They frequent moist forests and live in thick undergrowth. They are not migratory. Very little is known of their breeding, but they probably all make domed nests in thick creepers against trunks of trees.

Shortwings, (Brachyptery'x, Callene, Hodgsonius).-Are found only in mountainous countries and like the wrens frequent dense underwood in forests. Very little is known of them, but they do not appear to be migratory.

Whistling thrushes, (Myiophonus).-Are hill birds, though they extend especially in the cold weather into the forests below. They are seldom found far from water or in open country, and they breed in retired places exclusively in the hills. The eggs are long, pointed, and freckled all over with minute spots.

Ground thrushes, (Hydrornis, Pitta).-Are birds of very retiring habits, keeping on or near the ground in tangled brushwood or dense eover. They appear to be very local in their distribution, and some of them migrate, but their shyness prevents much observation of their habits. The eggs are white, more or less spotted and streaked.

Water ouzels, (Hydrobata).-Are only found in the Himalayas frequenting streams of running water. The eggs are pure white.

Long-billed thrushes, (Zoothera).-Only one species is found in India. It is confined to the Himalayas, and frequents tangled brushwood by streams in dense forest. Nothing is known of its nidification or migrations. The eggs of Zoothera, as far as they are known, resemble those of Pitta.

Rock thrushes, (Petrocossyphus).-Are migratory birds frequenting rocky plains. They are only known to breed in India in the far north-west. The eggs are blue, slightly speckled.

Chat thrushes, (Orocotes).-Are found commonly on wooded hills. They breed only in the Himalayas, but in the winter descend to the warm valleys and even to the plains. They all build their nests on the 
ground; and their eggs are clouded somewhat similarly to the eggs of the English robin.

Bush thrushes, (Geocichla).-Are migratory, breeding only in the hills, but extending far into the plains in the cold weather. They frequent open forests and glades. The position and shape of nest and the colour of the eggs are exact miniatures of those of the blackbirds to which these birds are very closely allied.

Blackbirds, (Turdulus, Merula).-Breed only in the hills and wander less in. the cold weather than the bush thrushes or true thrushes. In habits and nidification, and also in the colour of their eggs, they closely resemble the English blackbird.

Thrushes, (Turdus, Planesticus, Oreocincla).-The true thrushes are rare in India. The Nilgiri thrush (O. nilgiriensis) is found in the bills of south India as a permanent resident. The black-throated thrush ( $P$. atrogularis) is a cold weather visitant to the plains of upper India. The small-billed mountain thrush (O. dauma), which breeds in the Himalayas, also visits the plains in the winter, but the remainder of the thrushes are only found in the Himalayas. Many of them being extremely rare. Of the breeding of the genus Planesticus, nothing is known in this country. The eggs of Oreocincla are like miniatures of the whistling thrushes; being long, pointed, and freckled all over with minute pale spots. The breeding of the genus Turdus out here is similar to that of the missel thrush at home.

Finch thrushes, (Paradoxornis, Heteromorpha).-Nothing is known of their nidification. They are shy birds and rare, frequenting thick cover. They are only found in the eastern Himalayas and Khasia hills, where they are probably permanent residents, at 3,000 to 10,000 feet above the sea.

Tit thrushes, (Chleuasicus, Suthora).-Are also rare and confined to the eastern Himalayas and Khasia hills. Of their nidification nothing is known. They frequent brushwood and grass jungle.

Jay thrushes, (Conostoma, Grammatoptila).-Are shy, forestloving birds, only found in the higher ranges of the eastern Himalayas. The red-billed jay thrush ( $C$. comodium) is only found near the snows. They do not appear to migrate. They build in thick brushwood or forest. The egg of Conostoma is white, with blotches and streaks. That of Grammatoptila is pale blue unspotted.

Shrike thrushes, (Thamnocataphus, Gampsorhynchus).-Are also 
confined to the eastern Himalayas, and their nidification is unknown. They occur at low elevations and frequent brushwood. Of one kind, the white-winged shrike thrush (T. picatus), only one specimen has ever been procured.

Tit babblers, (Pyctorhis, Trichastoma).-Only one of these, the yellow-eyed babbler ( $P$. sinensis) is common. The other species are only found in north-east India. They frequent low jungle and brushwood, and are not migratory, breeding wherever they are found. The egg of the only species of which the breeding is known is beautifully marked with spots, clouds, and streaks.

Quaker thrushes, (Alcippe).-Are small birds frequenting dense forests and chiefly hilly countries. They are not migratory nor gregarious to any extent. The eggs are profusely spotted, and sometimes lined or blotched.

Wren babblers, (Stachyris, Mixornis, Timalia, Dumetia, Pellorneum).-Are a Malayan family, and the greater number of the species are confined to the north-east corner of India. The genus Stachyris is confined to the Himalayas, and is a strictly arboreal genus. All the others frequent brushwood and low thick jungle, and are generally gregarious. Mixornis and Timalia are eastern Himalayan forms. Dumetia is found in all India, but not very common anywhere. Pellorneum has an equally wide distribution, but is more common in hilly than level countries. They do not migrate. They build on or near the ground in brushwood. The eggs of some are pure white, of others more or less thickly speckled, and in one case, that of the rufous-bellied wren babbler ( $D$. hyperythra), the eggs are streaked as well as spotted.

\section{Scimitar babblers, (Pomatorhinus, Xiphoramphus.)-This} is purely a hill genus. They are found at low elevations haunting under wood in open forest country. They do not migrate. One species is found in the Nilgiris. All the others are confined to the Himalayas and hill ranges of north-east India. They build on or very near the ground making a domed nest and laying very fragile elongated eggs. These are always, as far as is known, pure white, unspotted.

Laughing thrushes, (Garrulax, Trochalopteron.)-A group of richly-coloured, noisy, and generally gregarious birds which do not migrate and are confined to hilly countries. The nests are solitary, but the birds even in the breeding season keep usually in small parties. They are never found far from forests and love densely wooded tracts. 
One species of Garrulax and three species of Trochalopteron are found in the hills of south India. The rest are all from the northern mountains. The nests are always in small trees or bushes in thick woods, never in open country. The eggs of one or two species are pure white; but the general colour of eggs of the various kinds of Garrulax is unspotted blue, sometimes pale, sometimes a very deep rich shade. In Trochalopteron the eggs are blue, sometimes unspotted. In one case (T. phoniceum) they are scrawled and streaked; but the usual type is that of the English song thrush (T. musicus) blue, with a few conspicuous dark spots.

Bar wings, (Actinodura).-Are confined to the eastern Himalayas and Khasia hills. They frequent forests, and though they breed on the ground, they are very arboreal in their habits. They occur usually from 3,000 to 10,000 feet elevations, and do not migrate. Their eggs are very. little known.

Sibias, (Siöia).-Are only found in the Himalayas and Khasia hills. They are noisy, do not migrate, and are strictly arboreal in their habits. The eggs are clouded and somewhat streaked on an ashy ground.

Babblers, (Acanthoptila, Malacocercus, Layardia, Chattarhaa). -Are some of the commonest and most widely spread birds in India. The genus Acanthoptila is confined to the Himalayas and is very little known. The others are plains birds, only one ( $M$. malabaricus) being confined to the hilly portions of south India. They are to be found everywhere feeding chiefly on the ground and flitting about in brushwood in small parties, being of gregarious habits; though the nests are always solitary. They lay unspotted blue eggrs. One species (C. earlii) is almost a reed-babbler, and is seldom found far from water. It frequents reeds and long grass among which its nest is placed.

Reed babblers, (Megalurus, Chatornis, Schœnicola, Eurycercus). - Are very local; partly gregarious and only found in marshy tracts. Some of them appear to migrate, but their habits are not well known. The eggs are usually spotted on a white ground, but more information is required.

Bulbuls, (Hypsepetes, Hemixos, Alcurus, Criniger, Ixos, Kelaartia, Rubigula, Brachypodius, Otocompsa, Pycnonotus, Phyllornis, Iora).The Malayan region is the head-quarters of the bulbul family, but no less than twenty-seven different kinds are found in India. They are found everywhere, and where found are permanent residents. Some 
kinds occur in the plains only and some in the hills. They are arboreal in their habits. Most of them prefer forest country, more or less dense, but some are found in open slightly wooded country. They build small neat cup-shaped nests, often very slight in structure; generally fixed in forks where two or three shoots divide near the ends of boughs; but sometimes hung from a horizontal fork like a tiny basket. The eggs are typically pinkish white, thickly spotted, and blotched with claret or purple. Of the green bulbuls (Phyllornis), the eggss are white, with a few brownish marks, and in the genus Iora the ground colour is greyish white, and the markings are very curious, jagged irregular streaks of greyish, reddish, or purplish brown.

Blue birds, (Irena).-Only one species is found in India, and that only in the Malabar forests. They are strictly arboreal in their habits and do not migrate. They keep in small parties near the tops of high trees. The nest is rough and untidy, not the least like an oriole. The eggs are pale greenish, streaked and spotted with dusky.

Orioles, (Oriolus).-Are permanent residents in India, but they wander much in the cold weather. They are quite arboreal in their habits, and build in trees a beautitul neat basket-shaped nest. They are not gregarious. The eggs are glossy white, with a few dark spots. They are found all over India, both in hills and plains.

Robins, (Copsychus, Kittacincla, Myiomela, Grandala, Thamnobia).-This group comprises many widely differing forms. The magpie robin (Copsychus saularis) is found throughout India in wooded tracts and gardens. The shama (Kittacincla macroura) is very local, and inhabits only dense thickets in forests. The long-winged blue chat (Grandala coelicolor) is a most anomalous form, approaching in some points very near the starlings. It is only found near the snow in the alpine Himalayas. The white-tailed blue chat (Myiomela leucura) is also confined to the Himalayas, and is found at rather high altitudes. The true robins of India (Thamnobia) are found in the open plains throughout the country. All the robins build on or very near the ground often in banks or clefts of rocks. They do not migrate; are solitary, and lay spotted or more often clouded eggs.

Bush chats, (Pratincola, Oreiocola).-A group of small birds found throughout the plains, especially in dry open country in the cold weather, but retiring, as a rule, to the hills to breed. Only a very few nestle in the plains. Their habits are very much those of the robins, 
and their nests and eggs are also very similar. The genus Oreiocol ${ }^{\alpha}$ differs from Pratincola, in that the only species which occurs bere (O. Jerdoni) is a shy, retiring bird, frequenting dense thickets and long grass jungle. Its breeding habits are unknown.

Stone chats, (Saxicola).-Are only cold weather visitants to this country, and are found in dry open plains; feeding on the ground and perching on stones, rocks, and occasionally on bushes. None of them are known to breed in India ; but where they do breed, their nests are on the ground near shelter, and the eggs are blue, with a few faint spots.

Rock chats, (Cercomela).-Are very similar in their habits to stone chats, and are found in similar localities. One (C.fusca) is a permanent resident in India, and breeds where it is found. Of the other very little is known. It is extremely rare. Their eggs are like those of stone chats.

Redstarts, (Rutacilla, Chomorrornis).-The redstarts are all migratory, only one ( $R$. rufiventris) wanders throughout India in the cold weather, but many species are found in the Himalayas. They are generally to be met with by water - in open country. One species (C. leucocephala) breeds in the alpine Himalayas, and the plumbous water robin ( $R$. fuliginosa) breeds throughout the Himalayas. These two latter lay spotted eggrs. The others, as far as has been ascertained, lay unspotted blue eggs, rather elongated in shape; but they are not known to breed in this country.

Wood chats, (Larvivora, Ianthia, Tarsiger, Calliope, Cyanecula).-The wood chats are migratory birds. A few are found in the plains in the cold weather. A few breed in the hills, and others leave the country altogether for breeding purposes. They frequent open forests, perching low and feeding near the ground. The blue throat wood chat (Cyanecula suecica) is generally found near water, often in the weeds at margins of tanks. Their nasts are very little known, but the eggs appear to vary much in character. Of Larvivora the eggs are mottled and streaked. Of Ianthia they are faintly zoned. Of Tarsiger they are unspotted blue. Of C'alliope unspotted pale buff.

Reed warblers, (Acrocephalus, Arundinax, Dumeticola, Locustella, Tribura). - The reed warblers are generally migratory. The three species of Acrocephalus are found throughout India in the cold weather and retire to the Himalayas to breed. They lay white eggs thickly spotted. The other genera are very little known. They inhabit 
dense swamps and marshy tracts, and are very difficult to flush, and consequently rare in collections. None of them are known to breed in the plains.

Hill warblers, (Horornis, Horeites.) - A group of small plain coloured birds found at high elevations in the eastern Himalayas, and some on the Khasia hills. They frequent brush-wood and thick grass and shun observation. The eggs vary a good deal, but typically appear to be richly coloured, chocolate brown, or dull purple. The nests are near the ground in thick brush-wood.

Tailor birds, (Orthotomus).-Are found throughout India, shunning the dry open plains, and creeping about in trees or brush-wood. They are non-migratory, and the eggs are spotted.

Wren warblers, (Prinia, Drymoipus, Burnesia, Franklinia).A large group of tiny birds which are spread throughout India, not however ascending the Himalayas to any height. They affect open plains or gardens creeping about in grass or bushes. They make purselike nests, deep with an opening near the top, or a little cup sewn in leaves like a tailor bird's nest. They do not migrate, but breed wherever they are found. The eggs of the Prinias, with ten tail feathers, are brick red. Those of the Prinias, with twelve tail feathers, are blue, with small spots. The smaller species of Drymoipus lay blue eggs, richly streaked and blotched, while the larger species lay dull-coloured clouded eggs. Of Burnesia and Franklinia the eggs are profusely speckled.

Grass warblers, (Cisticola, Gramminicola).-Are spread locally throughout the plains in marshy spots, frequenting thick grass and shunning observation. The eggs are spotted.

Scrub warblers, (Drymoeca).--One species only is found, and that in the trans-Indus hills in low scrub jungle, where it is a permanent resident. The eggs are profusely spotted.

Tailed hill warblers, (Suya).-These birds are found only in the Himalayas where they take the place of the Drymoipi, which they much resemble in appearance and habits. They are not migratory in the true sense of the word, but descend to the warm valleys in the winter. The eggs are zoned.

Tree warblers, (Neornis, Hyppolais, Phylloscopus, Reguloides, Culicepeta, Abrornis, Tickellia).- A large group of very small birds, many of which are brightly coloured. They are migratory as a rule. Only one (Hyppolais rama) is known to breed in the plains, and that very 
raiely, the majority migrating north and west. The genus Neornis build cup-shaped nests, and lay deep dull purple red eggs, with a tendency to a zone at the large end. They are permanent residents in the eastern Himalayas. Of the breeding of the Phylloscopi very little is known, but some of them certainly breed in the Himalayas. The Reguloides, Culicepeta, and Abrornis also breed in the Himalayas to a great extent; typically they make domed nests on the ground in mossy or grassy banks; but some build high up in trees (as $R$. proregulus), and others (as $R$. occipitalis) breed often in holes in decayed trees. The eggs of Culicepeta, Abrornis, and at least one of the Reguloides (R. occipitalis) are pure white, with some of the Reguloides, they are spotted, but the breeding of these birds is comparatively little known. Of Tickellia the breeding is unknown, but it appears to be a permanent resident in the Himalayas.

\section{Golden-crested wrens, (Regulus).-Only one species is} known, and that is a permanent resident in the Himalayas at high elevations. In habits it closely resembles the English golden-crested wren, and its nest is similar, but the eggs have not as yet been taken.

Whitethroats, (Sylvia).-Are migratory birds, appearing in the plains of India in the cold weather. One species only ( $S^{:}$affinis) is known to breed in the north-west Himalayas, and this in its habits is identical with the English whitethroat.

Fork tails, (Henicurus). - Are an Indo-Malayan family of birds. They occur in India only in the Himalayas, and are not migratory. They are always found near water, generally running water. The nest is a shallow compact structure of mosses and roots and fibres placed on banks or rocks, and the eggrs are speckled in all the species of which the breeding is known.

Wagtails, (Budytes, Motacilla, Nemoricola).-Are very migratory birds. Only two appear to be permanent residents in the plains of India: one the Indian pied wagtail ( $M$. maderaspatana), the other a very anomalous form, the black-breasted wagtail (Nemoricola indica), which is rare every where, and of which the nest has never been taken. Of the remainder, three species ( $M$. luzionensis, $M$. melanope, and $B$. calcaratus) are known to breed in the Himalayas. The rest probably migrate still further north; breeding in Turkistan. In habits they are all alike keeping to plains near water or moist fields, building a shallow nest of roots and hair on the ground and laying speckled eggs. 
Pipits, (Pipastes, Anthus, Corydalla, Agrodroma, Heterura).-Are as a rule migratory, though many of them are permanent residents in some parts of India. One of the tree pipits (P. montanus) appears to be confined to the Nilgiris. The others are cold weather visitants to the plains, retiring to the alpine Himalayas to breed. So also with the true pipits (Anthus as restricted), which are known to breed on this side of the snows. Of the titlarks (Corydalla), one (. . rufula) is a very common permanent resident throughout the plains. The others are only cold weather migrants. Of the stone pipits (Agrodroma), one ( $A$. griseorufescens) is a cold weather visitant to the plains, but breeds in the north-western Himalayas; another (A. campestris) is abundant in the cold weather, and is said to breed in the plains, but this requires confirmation; the third (4. cinnamomea) is confined to the Nilgiris, where it is a permanent resident. The genus Heterura, of which there is only one species in India, is confined to the Himalayas, where it is a permanent resident. All the pipits make their nest on the ground, sheltered by grass, on open plains or hill sides, and lay richly blotched or spotted eggs.

Thrush tits, (Cochoa).-Are a very remarkable group of birds. They are confined to the eastern Himalayas, frequent forests at moderate elevations, and in their nidification and eggs much resemble blackbirds. There are only two species in India, both rare.

Shrike tits, (Pteruthius).-Are confined to the Himalayas. Of one kind ( $P$. rufiventer), the nest has never been found. Of the other (P. erythropterus), the egg is one of the rarest in collections. The shrike tits are arboreal in their habits, frequent well-wooded slopes at moderate elevations. They lay speckled eggs in a basket-shaped nest of moss and roots hung from a fork near the top of a tree.

Hill tits, (Allotrius, Cutia, Leioptila, Leiothrix, Siva, Minla, Proparus, Ixulus, Yuhina, Myzornis, Erpornis).-Are also confined to the Himalayas, and with few exceptions to the eastern Himalayas and such outlying ranges as the Khasia hills. They are very arboreal in their habits, frequent well-wooded tracts, and generally associate in small flocks. They usually make rather massive cup-shaped nests, about five to ten feet from the ground, and lay spotted eggs, in which the markings frequently form a zone at the large end. One species (Tukina nigrimentum) is known to lay pure white eggs, and another (Myzornis pyrrhoura) is believed to lay unspotted eggs also. As a rule these birds are not migratory, but breed wherever they are found. 
Tits, (Zosterops, sylviparus, Cephalopyrus, Egithaliscus, Lophophanes, Parus, Machlolophus, Melaniparus, Melanochlora).-Are as a rule confined to the Himalayas. One (Zosterops palpebrosus) is found throughout India as a permanent resident. One (Parus cinereus) is found in all wooded hills. Another (Parus nuchalis) is only found in central and south India. Another (Machlolophus jerdoni) is only found in the hills of south India. All the rest are confined to the Himalayas, and a great number of them are found in the eastern Himalayas only. They are not as a rule migratory, and are by no means shy, often associating in small flocks. The nest and eggs of Zosterops palpebrosus are quite aberrant (the eggs are pale unspotted blue). The nest of Sylviparus is unknown. So also are those of Melaniparus and Melanochlora. The nest of Egithaliscus is like that of the bottle tits in England, while all the others are typically "parine" in their nidification, building in holes, in walls, or decayed trees, and laying spotted eggs.

Hedge sparrows, (Accentor).-There are several kinds of hedge sparrows found in the upper regions of the Himalayas; but nowhere else in India. They are not migratory, and their nests and eggs as far as is known are similar to those of the hedge sparrow in England.

Ravens and crows, (Corvus).-Ravens are found only in the Himalayas and western continental India. They frequent open country, and do not appear to be entirely migratory, though they wander far in the cold weather. Crows are found all over India. Their nests and eggs are all of one general type, which is well known.

Jackdaws, (Colceus).-One species, the common jackdaw ( $\boldsymbol{C}$. monedula) is found in the north-west Himalayas, where it is a permanent resident. Its habits are well known. It migrates to the Punjab in the winter, but does not breed there.

Nutcrackers, (Nucifraga).-Are confined to the Himalayas, chiefly the western Himalayas. They keep to rather high elevations, frequent pine forests, and in habits closely resemble jays and magpies. They are not migratory.

Magpies, (Pica).-Two species occur in the alpine Himalayas, where they are permanent residents. Their habits are identical with those of the English magpie.

Jays, (Garrulus, Urocissa, Cissa).-Are found only in the Himalayas within the Indian limit. They keep to open forests, are not migra- 
tory, and feed partly on the ground. The eggs of all are profusely spot. ted, and the nest is generally a loose structure of twigs, with a slight inner casing of fine roots.

Tree pies, (Dendrocitta).-Are found throughout India in wooded country. Their habits and nests are very similar to those of the jays, and they do not migrate, but the eggs are less thickly spotted.

Choughs, (Fregilus, Pyrrhocorax).-Are permanent residents in the alpine Himalayas; but their breeding in this country has only very recently been ascertained. They nestle in holes, in rocks, and in buildings, and their eggs are similar to those of the European chough. A few migrate as far south as the Punjab in the cold weather.

Starlings, (Sturnus).-A Are cold weather visitants to the plains of India, migrating north and west to breed. One only ( $S$. nitens) breeds within our limits in Kashmir and the extreme north-west Punjab. They build in holes and lay unspotted blue eggs.

Mynahs, (Sturnopastor, Acridotheres, Temenuchus, Pastor, Saraglossa, Eulabes).-As a rule these birds are not migratory. The genus Pastor perhaps more properly belongs to the starlings. The only species of Pastor that occurs here ( $P$. roseus) is very migratory, and does not breed in this country. The true mynahs (Acridotheres, Temenuchus, Sturnopastor) are very domestic, and are found almost everywhere. The stare (Saraglossa) is confined to the Himalayas, and the grackles (Eulabes) to warm forest country. All build in holes, except the pied mynah ( $S$. contra) which makes a conspicuous nest like a truss of hay in the outer fork of a bare tree. The eggs of the rose-coloured pastor ( $P$. roseus) are not known. The true mynahs lay unspotted blue eggs. But the eggs of the stare and of the grackles are all spotted.

Weaver birds, (Ploceus).-Are highly gregarious, but not migratory. They are somewhat locally distributed, and prefer wooded country near long grass and water. They lay pure white eggs.

Munias, (Munia, Estrelda).--Are all permanent residents in some part of India. They wander a good deal in the cold weather, and frequent grass jungle near water or open glades in forests. They make large rough globular nests and lay pure white eggs.

Sparrows, (Passer).-Are widely distributed and do not as a rule migrate, though in the winter they associate in flocks. Their eggs are all profusely spotted.

Buntings, (Emberiza, Euspiza, Melophus).-Are usually migratory 
birds, found in this country chiefly in the cold weather. Two species (Emberiza striolata and Melophus melanicterus) are permanent residents and bieed in the plains. Two or three kinds of buntings breed in the Himalayas, but all the rest go further north or west to breed. They frequent open ground or rocks with scanty jungle. The corn buntings (Euspiza) are generally found in cultivated ground. They all nestle on or close to the ground, under shelter, and the eggs are spotted and often scrawled with fine hair-like lines.

Finches, (Hesperiphona, Mycerobas, Pyrrhula, Pyrrhoplectes, Loxia, Hamatospiza, Propyrrhula, Carpodacus, Propasser, Procarduelis, Pyrrhospiza, Callacanthis, Carduelis, Chrysomitris, Metoponia, Fringilla, Montifringilla, Fringillauda).-A few finches wander to the foot of the hills in the winter, but the common rose finch (Carpodacus erythrinus) is the only one found in the plains of India. All the others occur in the Himalayas only, chiefly at high elevations. They are all more or less migratory. Of arboreal habits, frequenting forests and wooded tracts, and of their breeding, very little is known. All the eggrs of this group that are known are prettily, some very handsomely, marked.

Bush larks, (Mirafra).-Are spread throughout the plains of India. They frequent open forests, grass jungle, and edges of cultivation, are not migratory, build on the ground in short grass, and lay profusely spotted eggs.

Finch larks, (Ammomanes, Pyrrhalauda).-Are also permanent residents of the plains of India frequenting drier and more open ground and avoiding cultivation. They are widely distributed. Their eggs are profusely speckled.

Larks, (Calandrella, Melanocorypha, Alaudala, Otocoris, Spizalauda, Alauda, Galerita, Certhilauda).-Are more or less migratory, associating in flocks in the cold weather, but many species breed in India. The short-toed larks (Calandrella), the calandra larks (Melanocorypha), the horned larks (Otocoris), and probably also the desert larks (Certhilauda) are merely cold weather visitants, and do not breed at all within our limits. The Himalayan sky lark ( $A$. dulcivox) breeds only in the Himalayas, while the others breed in suitable localities throughout the country. The sky larks (Alauda) affect damp grassy spots. The sand larks (Alaudala) frequent the sandy beds of large rivers. All the others are found in dry, open, or cultivated plains. They all build on the ground and lay spotted eggs. 
Pigeons, (Treron, Crocopus, Osmotreron, Sphenocercus, Carpophaga, Alsocomus, Palumbus, Palumbran, Columba). - There areseveral well-marked groups of pigeons. The green pigeons (Treron, Crocopus, Osmotreron, Sphenocercus) are forest-lovirg, fruit-eating birds, partly gregarious, and wandering a good deal during the winter, though all are permanent residents of the Indo-Malayan region, and the species that occur in India breed there too. The imperial pigeons (Carpophaga) are similar in their habits, but even more confined to dense forests. The wood pigeons (Alsocomus, Palumbus) are more migratory, more shy, and with one exception confined to mountain ranges. The stock pigeon (Palumboena) is strictly migratory, visiting India in the cold weather only, in vast flocks. The true pigeons (Columba) are gregarious, and are probably permanent residents where they occur, but this has only been ascertained in the case of the common blue pigeon ( $C$. intermedia). All pigeons lay either one or two pure white eggs on a small rough platform of sticks.

Doves, (Macropygia, Turtur, Chalcophaps).-Are less gregarious than pigeons. They all breed in India. Only one, Sykes' turtle dove (T. meena), appears to wander much from its breeding place. They feed almost entirely on the ground, and are very widespread in this country. They lay two pure white eggs on a tiny platform of sticks.

Sandgrouse, (Pterocles, Syrrhaptes).-Are usually only cold weather visitants to this country. They associate in large flocks, and frequent dry, open, or cultivated plains. The painted sandgrouse $(P$. fasciatus) affects rocky ground, and the Thibetan sandgrouse (Syrrhaptes tibetanus) is only found in the Himalayas at great elevations. Two only of the sandgrouse, the common and the painted, are known to breed with any regalarity in this country. Their eggs are richly coloured and blotched. In shape they are elongated and cylindrical. The eggs of a third kind P. lichtensteini have lately been taken in Sind.

Pheasants, (Pavo, Polyplectron, Lophophorus, Ceriornis, Euplocamus, Ithaginis, Pucrasia, Phasianus, Gallophasis).-With the exception of the peacock (Pavo cristatus), which is found in wooded tracts throughout India, the Phasianidoe are confined to the Himalayas. They are found at all elevations, but only in forest country, with dense undergrowth. They are all permanent residents, breeding on the mountains, and descending into the valleys in the winter to feed. The eggs of many of them are boldly blotched, while others approach closely to the eggs of domestic fowls. 
Jungle fowl, (Gallus).-Are more tropical birds, being found in dense thickets and forests throughout the country. They too are permanent residents, breeding where found. The eggs are like those of the Cochin-China fowls.

Spur fowl, (Galloperdix).-Are confined to rocky ridges and the dense jungles that fringe their bases in central and southern India where they breed. They are shy and wary, and conceal themselves in the densest cover. The eggs vary from creamy white to "cafe au lait."

Grouse, (Tetraogallus, Lerwa).-Are only found near the snow in the alpine Himalayas. They lay boldly blotched eggs as far as has been ascertained, and frequent grassy and rocky slopes near snow.

Partridges, (Perdix, Francolinus, Caccabis, Ammoperdix, Ortigornis, Arboricola).-Of the true partridges only one ( $P$. hodsonice) is found in India. It frequents the alpine Himalayas at great altitude. The black and painted partridges (Francolinus) frequent thick jungle and grass near water and cultivation. The rock partridges (Caccabis, Ammoperdix) frequent rocky hills and open grassy slopes. Of the grey partridges one ( $O$. gularis) is a swamp partridge found only in the Terais, the other is common where there is cover throughout the plains. Wood partridges (Arboricola) are only found in the Himalayas in dense under-wood in forests, and are difficult to flush. Partridges do not migrate and breed wherever found. The eggs of the chukor are spotted. All other partridges lay unspotted, buff, or cream coloured eggs.

Quails, (Perdicula, Coturnix, Excalfatoria, Turnix).-Some of the quails are migratory, but all that occur in India breed more or less in this country. The bush quails (Perdicula) frequent jungle and underwood, so does the blue-breasted quail ( $E$. chinensis). The other quails affect cultivation or grassy plains. The eggs of the bush quails are like miniature partridges' eggs. The eggs of the true quails (Coturnix) are boldly blotched; and those of the bustard quails and button quails are profusely spotted and speckled.

Bustards, (Eupodotis, Houbara, Sypheotides, Otis).-The great bustard ( $E$. edwardsii) is a permanent resident in the arid portions of continental India, frequenting low scrub and scanty grass jungle. The florikin ( $S$. bengalensis) is a permanent resident in the dense grass jungles of eastern upper India. The likh (S. auritus) is found throughout India in the cold weather in suitable localities, but as yet it has 
only been known to breed in the Deccan among tufts of grass on cotton soil. The houbara and the true bustards (Otis) are only found in the arid plains of the extreme north-west. All the bustards lay dark-coloured handsomely marked eggs.

Plovers, (C)ursorius, Rlinoptilus, Glareola, Squatarola, Charadrius, Egialites, Vanellus, Chettusia, Lobivanellus, Sarciophorus, Hoplopterus, Esacus, Edicnemus, Strepsilas, Dromas, Hamatopus).-Plovers are more or less gregarious and widely spread in India. They frequent open country, avoiding forests entirely as a rule, and feeding on the ground in ploughed or fallow fields. The grey plover (Squatarola helvetica), the golden plover (Charadrius longipes), all the ringed plovers (Egialites), except $\mathscr{E}$. curonicus, the crested lapwing ( $\nabla$ anellus cristatus), the true lapwings (Chettusia), and the oyster catcher (Hamatopus ostralegus), are migratory and only visit this country in the cold season. The remainder are either known or believed to breed in India. The courier plovers (Cursorius), the wattled lapwings (Lobivanellus, Sarciophorus), and the stone plover (EEdicnemus) breed in fields or plains away from water. Of the breeding of the genus Rhinoptilis nothing is known, but they frequent scanty jungle on rocky hills. The swallow plovers(Glareola), the ringed plovers (Egialites), the spur-winged plovers (Hoplopterus), and the great stone plover (Esacus) lay their eggs on the bare sand in the beds of great rivers. While the turnstone (Strepsilas interpres) and the crab plover (Dromas ardeola) lay on the sand on the sea-coast. The eggs of all plovers are dark-coloured and richly marked.

Cranes, (Grus, Anthropoides).-The only crane that permanently resides in India is the sarus (Grus antigone). It feeds in open plains and fields, but breeds on islands in swamps among rushes. All the other cranes are migratory visiting India in the winter in large flocks. The eggs are spotted or blotched.

Snipe, (Scalopax, Gallinago, Rhynchaa).-The painted snipe ( $R$. bengalensis) is the only permanent resident. It is somewhat local and affects thick weeds in marshy places. The woodcock ( $S$. rusticola) visits the lower Himalayas in the winter, also the hilly portions of the south of India. A few pairs at least breed in the alpine Himalayas. The true snipe (Gallinago) are all migratory coming in the cold weather. A few of the common snipe may breed in the northwest Himalayas, but, as a rule, all the snipe go beyond Indian limits to breed. The eggrs are handsomely marked. 
Godwits, (Macroramphus, Limosa, Terekia).-Are only winter visitants. None of them breed in this country.

Curlews, (Numenius, Ibidorhynchus).-Are cold weather visitants and breed beyond the border.

Stints, (Philomachus, Tringa, Eurinorhynchus, Calidris, Phalaropus).-Are merely cold weather visitants.

Sandpipers, (Actitis, Totanus, Himantopus, Recurvirostra).-Are all migratory. The stilt (H. candidus) congregates for breeding purposes in one or more localities in the plains. The common sandpiper ( $A$. hypoleucus) breeds in considerable numbers in the beds of rivers in Kashmir ; but all the other birds of this class go beyond the border to lay their eggs. The eggs are spotted or blotched on a buffy ground.

Jacanas, (Hydrophasianus, Metopidus).-The water pheasants are permanent residents, frequenting weedy marshes. In the cold weather they retire to the moister districts, but in the rains they wander wherever there are marshes. They lay deep bronze-coloured eggs. In one species unmarked, in the other scrawled all over with fine black lines.

Coots, (Porphyrio, Fulica, Gallicrex, Gallinula).-Are all permanent residents, frequenting marshes and ponds or dense thickets near water. They breed both in hills and plains. Their eggs are spotted.

Rails, (Porzana, Rallus).-Of these birds very little is known. They frequent dense weeds and thickets near water. They breed both in the hills and plains, but are flushed with difficulty, and it is not known whether they migrate. The eggs typically are spotted.

Storks, (Leptoptilus, Mycteria, Ciconia, Melanopelargus).-The true storks (Ciconia) are cold weather visitants, and do not breed in India. The adjutants (Leptoptilus) have special breeding places to which they resort. While the other storks (Mycteria and Melanopelargus) breed throughout India on high trees near water. Their eggs are dingy white unspotted.

Herons, (Ardea, Herodias, Demi-egretta, Buphus, Ardeola, Butorides).-Are permanent residents, breeding on trees near water in all parts of India. They all lay unspotted blue eggs.

Bitterns, (Ardetta, Botaurus).-It is not as yet ascertained whether the common bittern (Botaurus stellaris) is a permanent resident, but probably it, as well as all the other bitterns, breeds in India. They frequent thick reeds in swamps, are very difficult to flush, and lay unspotted greenish eggs. 
Night herons, (Nycticorax).-Are found near water. They are permanent residen is breeding on trees, and sometimes it is said in reeds. They lay pale green eggs.

Ibises, (Tantalus, Platalea, Anastomus, Threskiornis, Geronticus, Falcinellus).-The glossy ibis (Falcinellus igneus) is a cold weather visitant, coming in in large flocks, and leaving the country when the breeding season comes. All the others are permanent residents, and are as a rule gregarious breeders, making their nests on high trees near water. The eggs of the pelican ibis ( $T$. leucocephalus) are dull white; so also are those of the shell ibis ( $A$. oscitans). Those of the white ibis ( $T$. melanocephalus) are very pale green, and the spoonbill $(P$. leucorodia) and the king curlew (G. papillosus) lay spotted eggs.

Flamingoes, (Phoenicopterus).-Are cold weather visitants, and do not breed in this country.

Geese, (Anser, Sarkidiornis).-The black-backed goose ( $S$. melanotus) is found throughout the country in swampy parts and is a permanent resident. All the other geese leave India to breed elsewhere. The eggs are ivory white.

Ducks and Teal, (Nettapus, Dendrocygna, Casarca, Tadorna, Spatula, Anas, Chaulelasmus, Dafila, Mareca, Querquedula, Branta, Aythya, Fuligula, Clangula, Mergus).-Almost all the ducks are migratory coming to India for the winter months only. The cotton teal (Nettapus coromandelianus), the two whistling teal (Dendrocygna arcuata and D. major), the spotted-billed duck (A. pocilorhynchus), and the pink-headed duck (A. caryophyllacea) are permanent residents, and breed where they occur in the plains of India. The mallard (Anas boschas) and the white-eyed duck (Aythya nyroca) remain to breed in Kashmir. All the rest go farther north towards central Asia. The eggs are glossy white, buff or "cafe au lait."

Grebes, (Podiceps).-The little grebe ( $P$. philippinus) is found on tanks and ponds throughout India, and is a permanent resident. The crested grebe is a winter migrant in continental India, retiring to Kashmir to breed. The eggrs are dull white.

Gulls, (Larus, Xema); Petrels, (Thallassidroma, Pelicanoides); Puffins (Pufinus).-Are found at sea round the coast. Some of the gulls coming far inland at times. None of these birds breed within our limits, but they are believed to lay on the rocky islands of the Red sea.

Terns, (Sylochelidon, Gelochelidon, Hydrochelidon, Seena, Sterna, 
Sternula, Thallasseus, Onochoprion, Anous).-Terns are as a rule migratory, and congregate in flocks during the breeding season. The Caspian tern ( $S$. caspius) does not breed in this country; and the gull-billed tern ( $G$. anglicus) only breeds in the far north-west. The marsh terns (Hydrochelidon) breed here and there in India gregariously on weeds floating in swamps. The true terns (Gelochelidon; Sterna, Seena, Sternula) lay their eggs on the bare sand in the beds of large rivers. The sea terns (Thallasseus, Onochoprion, Anous) lay on bare rocky islands off the sea-coast. All the terns lay handsomely marked eggs.

Skimmers, (Rhynchops).-A Are permanent residents here, and are similar in their eggs, habits, and distribution to the true terns (Sterna).

Fishers, (Phaeton, Sula, Attagen).-Are all sea-birds which are found in Indian waters, but which are not known to breed on our coasts.

Pelicans, (Pelecanus).-Pelicans are widely spread throughout India in the cold weather, but of their breeding here nothing is known. They are said to build on trees.

Cormorants, (Graculus).-Are permanent residents in India, frequenting rivers and large tanks. They are gregarious and consequently local breeders. The breeding of the big cormorant (G. carbo) is not accurately known; and this bird is certainly to a great extent migratory. The eggs of cormorants are dull chalky white.

Snake Birds, (Plotus).-Are permanent residents in India, and are similar in their habits and eggs to the cormorants. 
, $\quad$ Cot 


\section{P A R T I I.}

I N D E X.

LIST OF BIRDS THAT ARE KNOWN TO BREED IN INDIA, SHOWING DURATION OF BREEDING SEASON.

THIs list only contains those birds of which the eggs have been taken : of course, many more birds do breed here, and further research would greatly extend the list.

Column I gives the number as in Jerdon's hand-book of the Birds of India. Where no number is given in this column, it indicates a species added to the list of birds of India, since Jerdon's book was published.

Column II gives the English name of each bird. In most cases the name as given by Jerdon is adhered to. In some cases where it seemed advisable the alterations introduced by $\mathrm{Mr}$. Hume in his more recent works have been adopted; and in a few cases alterations have been made which further knowledge has rendered desirable.

Column III gives the scientific name for each bird. In this column many deviations from the names as given by Jerdon, both generic and specific, will be found; but the revisions shown in Mr. Grav's hand-list have not been adopted in their entirety as they quite revolutionise the nomenclature heretofore in use, and with which we have become through Jerdon's book familiar; and though possibly Mr. Gray's list may be more scientifically correct, it is inexpedient to adopt it in this book which is written chiefly for beginners in this country, in whose hands Jerdon is the only text-book; for the disadvantage of a wholesale change, especially on merely arbitrary points, is obvious. Where it has been absolutely necessary for accuracy, I have entered the new names; and in case of a difference, the number (in Jerdon), which is quoted in Column I, will determine the bird referred to. 
The remaining columns require little explanation. The portion marked off opposite each bird's name indicates the season and duration of the period in which its eggs may be found.

The breeding season thus noted includes every month in which each bird is known to breed in any locality. Where the breeding of a bird is confined for any particular season to any particular locality, a letter signifying the locality is placed over the line denoting the breeding during that month. Where no distinguishing letter is placed over the line, it indicates that the bird in that month is breeding wherever it is found.

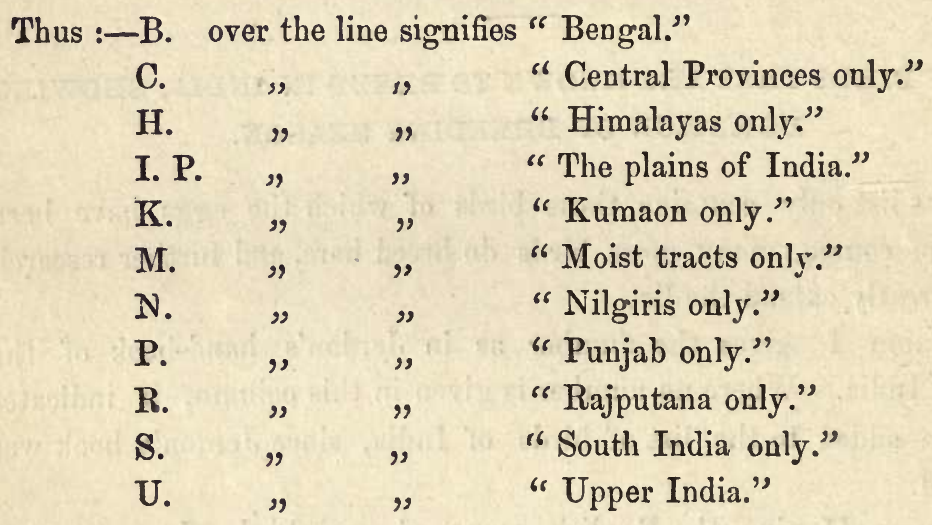


LIST OF BIRDS KNOWN TO BREED IN INDIA, SHOWING PERIOD AND DURATION OF BREEDING SEASON.

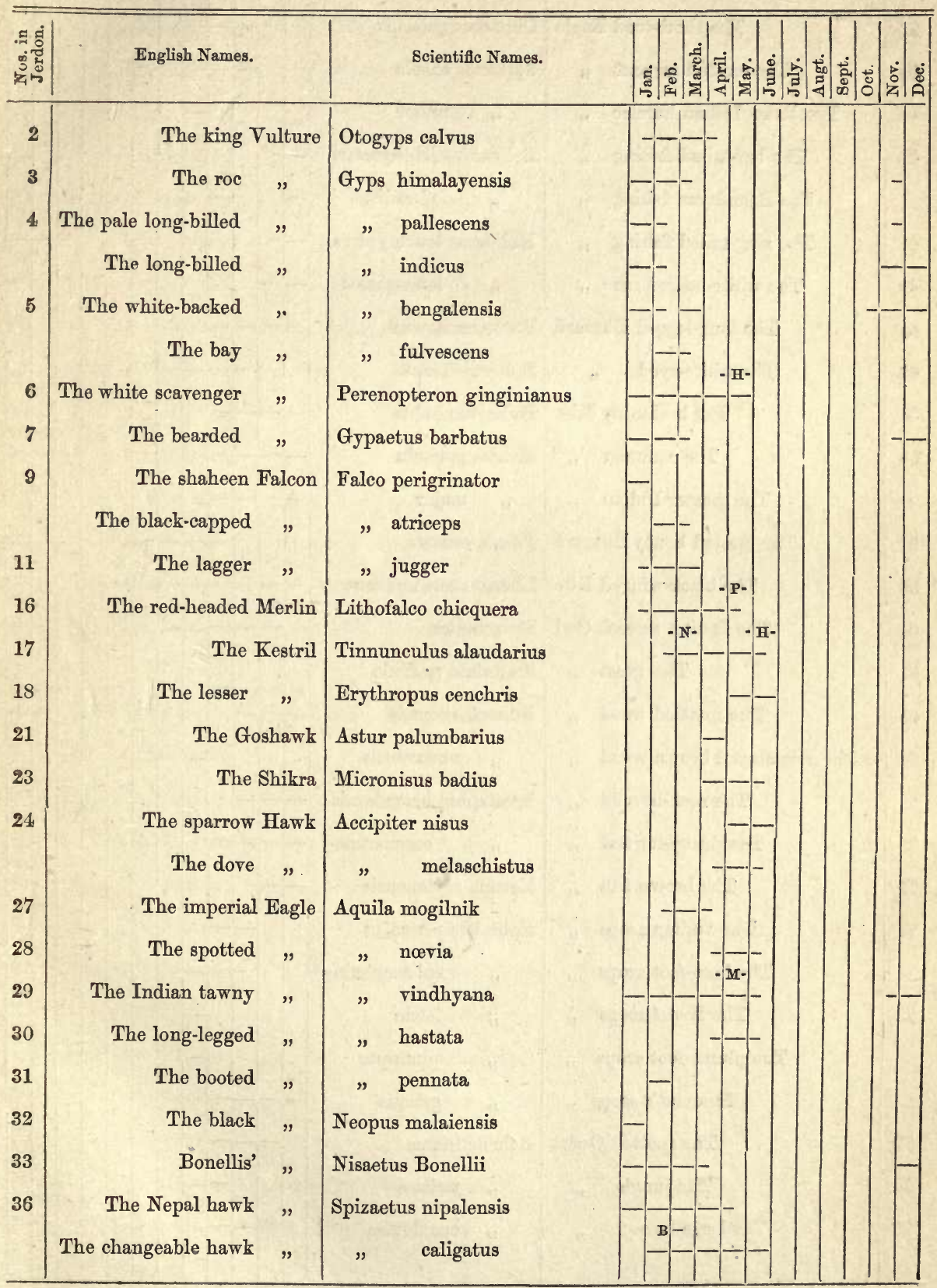




\begin{tabular}{|c|c|c|c|c|c|c|c|c|c|c|}
\hline 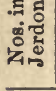 & English Names. & & Scientific Names. & 沾 & 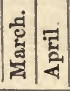 & $\mid$ & & $\begin{array}{ll}0 \\
\end{array}$ & के & \begin{tabular}{|c|}
$\dot{\dot{0}}$ \\
$\dot{2}$
\end{tabular} \\
\hline 38 & The short-toed Ea & agle & Circaetus gallicus & & & & & & & \\
\hline 39 & The crested serpent , & & Spilornis cheela & & & & & & & \\
\hline & The lesser Indian harrier, & & " minor & & & & & & & \\
\hline 41 & The bar-tailed fishing " & & Polioaetus ichthyaetus & $-?$ & & & & & & \\
\hline & The Himalayan fishing , & , & plumbeus & & & & & & & \\
\hline 42 & The ring-tailed fishing & " & Haliaetus leucoryphus & & & & & & & \\
\hline 43 & The white-bellied sea , & " & " leucogaster & & & & & & & - \\
\hline 45 & The long-legged Buzzs & $\operatorname{card}$ & Buteo canescens & & & & & & & \\
\hline 48 & The white-eyed & & Poliornis teesa & & & & & & & \\
\hline 55 & The brahminy $\mathrm{K}$ & Zite & Haliastur indus & & - & & & & & \\
\hline 56 & The common & " & Milvus govinda & & - & & & & & \\
\hline & The greater Indian & $"$ & " major & & & & & & & \\
\hline 57 & The crested honey Buzze & $\operatorname{ard}$ & Pernis cristata & & & & & & & \\
\hline 59 & The black-winged $\mathrm{K}$ & Kite & Elanus melanopterus & & & & & & & \\
\hline 60 & The Indian screech $\mathrm{O}$ & Owl & Strix indica & & & & & & & \\
\hline 61 & The grass & $"$ & Scelostrix caudida & & & & & & & \\
\hline 65 & The mottled wood, & " & Bulacca sinensis & & & & & & & \\
\hline 64 & The Himalayan brown wood, & " & " newarensis & & & & & & & \\
\hline 69 & The rock-horned, & " & Ascalaphia bengalensis & & & & & & & \\
\hline 70 & The dusky-horned, & ” & $" \quad$ coromanda & & & & & & & \\
\hline 72 & The brown fish, & ” & Ketupa ceylonensis & & & & & & & a- \\
\hline 74 & The Indian scops , & 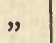 & Ephialtes pennatus & & & - & & & & \\
\hline & The bare-foot scops , & " & spilocephalus & & & & & & & \\
\hline 75 & The Nepal scops & $"$ & lettia & & & & & & & \\
\hline & The plume-foot scops & $"$ & " plumipes & & & & & & & \\
\hline & Pennant's scops & ” & " griseus & & & & & & & \\
\hline 76 & The spotted Ow & wlet & Athene brama & & & & & & & \\
\hline 77 & The jungle & , & $"$ radiata & & & & & & & \\
\hline 79 & The large barred & " & $"$ cuculoides & & & & & & & \\
\hline
\end{tabular}




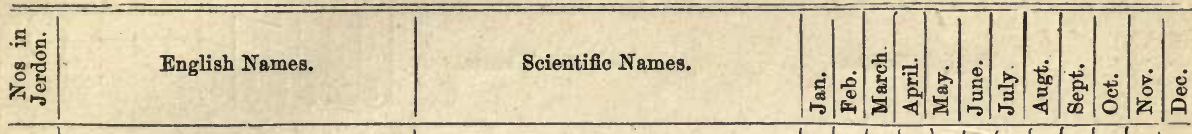

80

82

83

84

85

86

88

89

90

91

92
The collared pigmy Owlet

The common Swallow

The Nilgiri house "

The wire-tailed "

The great Indian mosque ,

The mosque "

The Indian cliff "

The dusky sand Martin

The common sand ,

The dusky crag "

The crag "

The house "

The Kashmir "

The common Indian Swift

The Palm roof "

The Palm "

The Southern hill Swiftlet

Horsfield's

The Indian crested Swift

The Sikkim Frogmouth

The jungle Nightjar

The Nilgiri

The large Bengal "

The Ghat "

The common Indian "

Franklin's "

Unwin's ,

Hodgson's Trogon

The common Bee eater
Glaucidium Brodiei

Hirundo rustica

, domicola

" ruficeps

" daurica

" erythropygia

Hirundo fluvicola

Cotyle subsoccata

"sinensis

„ concolor

" rupestris

Chelidon urbica

" cashmirensis

Cypselus abyssinicus

, infumatus

" batassiensis

Collocalia unicolor

, linchi

Dendrochelidon coronatus

Otothrix Hodgsoni

Caprimulgus indicus

$$
\begin{array}{cc}
" & \text { Kelaarti } \\
" & \text { albonotatus } \\
" & \text { atripennis } \\
" & \text { asiaticus } \\
" & \text { monticolus } \\
" & \text { Unwini } \\
\text { Harpactes Hodgsoni } \\
\text { Merops viridis }
\end{array}
$$

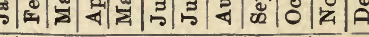




\begin{tabular}{|c|c|c|c|c|c|c|c|c|c|c|c|}
\hline 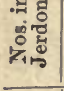 & English Names. & & Scientific Names. & ⿷ّ & 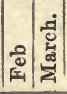 & & & 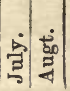 & & & $\stackrel{\square}{\square}$ \\
\hline 118 & The blue-tailed B & Bee eater & Merops philippensis & & & & & & & & \\
\hline 119 & The chestnut-headed & " & " quinticolor & & & & & & & & \\
\hline 120 & The Egyptian & " & " œgyptius & & & & & & & & \\
\hline 121 & The European & $"$ & $" \quad$ apiaster & & & & & & & & \\
\hline 122 & The blue-ruffed & ” & Nyctiornis Athertoni & & & & & & & & \\
\hline 123 & The common & n Roller & Coracias indica & & & & & & & & \\
\hline 125 & The European & n & " garrula & & & & & 1 & & & \\
\hline 126 & The broad-billed & $"$ & Eurystomus orientalis & & & & & - & & & \\
\hline 127 & The Indian stork-billed Ki & ingfisher & Pelargopsis gurial & & & & & & & & \\
\hline 129 & The white-breasted & $"$ & Halcyon smyrnensis & & & & & - & & & \\
\hline 134. & The little Indian & 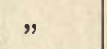 & Alcedo bengalensis & & & $1-1$ & - & & & & \\
\hline 136 & The pied & ” & Ceryle rudis & & & - & & & & & \\
\hline 138 & The yellow-throated B & roadbill & Psarisomus Dalhousiæ & & & & & & & & \\
\hline 140 & The great Indian $\mathrm{H}$ & Gornbill & Homraius bicornis & & & & - & & & & \\
\hline 144 & The Northern grey & " & Meniceros bicornis & & & -- & - & & & & \\
\hline 147 & The Northern rose-band $P$ & aroquet & Palooornis sivalensis & & & & & & & & \\
\hline 148 & The rose-ringed & 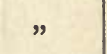 & $" \quad$ torquatus & & & - & & & & & \\
\hline 149 & The rose-headed & $"$ & " purpureus & & & - & & & & & \\
\hline 150 & The slaty-headed & $"$ & $" \quad$ schisticeps & & & - & & & & & \\
\hline 152 & The red-breasted & $"$ & $" \quad$ javanicus & & & - & & & & & \\
\hline 153 & The Indian I & Loriquet & Loriculus vernalis & & & - & & & & & \\
\hline 154 & The Himalayan pied Woo & dpecker & Picus himalayanus & & & - & - & & & & \\
\hline 156 & The lesser black & $"$ & " caphtharius & & & - & & & & & \\
\hline 157 & The Indian spotted & $"$ & " macei & & & - & & & & & \\
\hline 159 & The brown-fronted & $"$ & " brunneifrons & & & - & & & & & \\
\hline 160 & The yellow-fronted & $"$ & " mahrattensis & & & - & & & & & \\
\hline 161 & The rufous-bellied pied & ” & Hypopicus hyperythrus & & & - & & & & & \\
\hline 163 & The Himalayan pigmy & $"$ & Yungipicus pygmœus & & & - & & & & & \\
\hline 164 & The Southern pigmy & $"$ & " Hardwickii & & & & & & & & \\
\hline 167 & The Southern golden-backed & & Chrysocolaptes delesserti & & & & & & & & \\
\hline
\end{tabular}




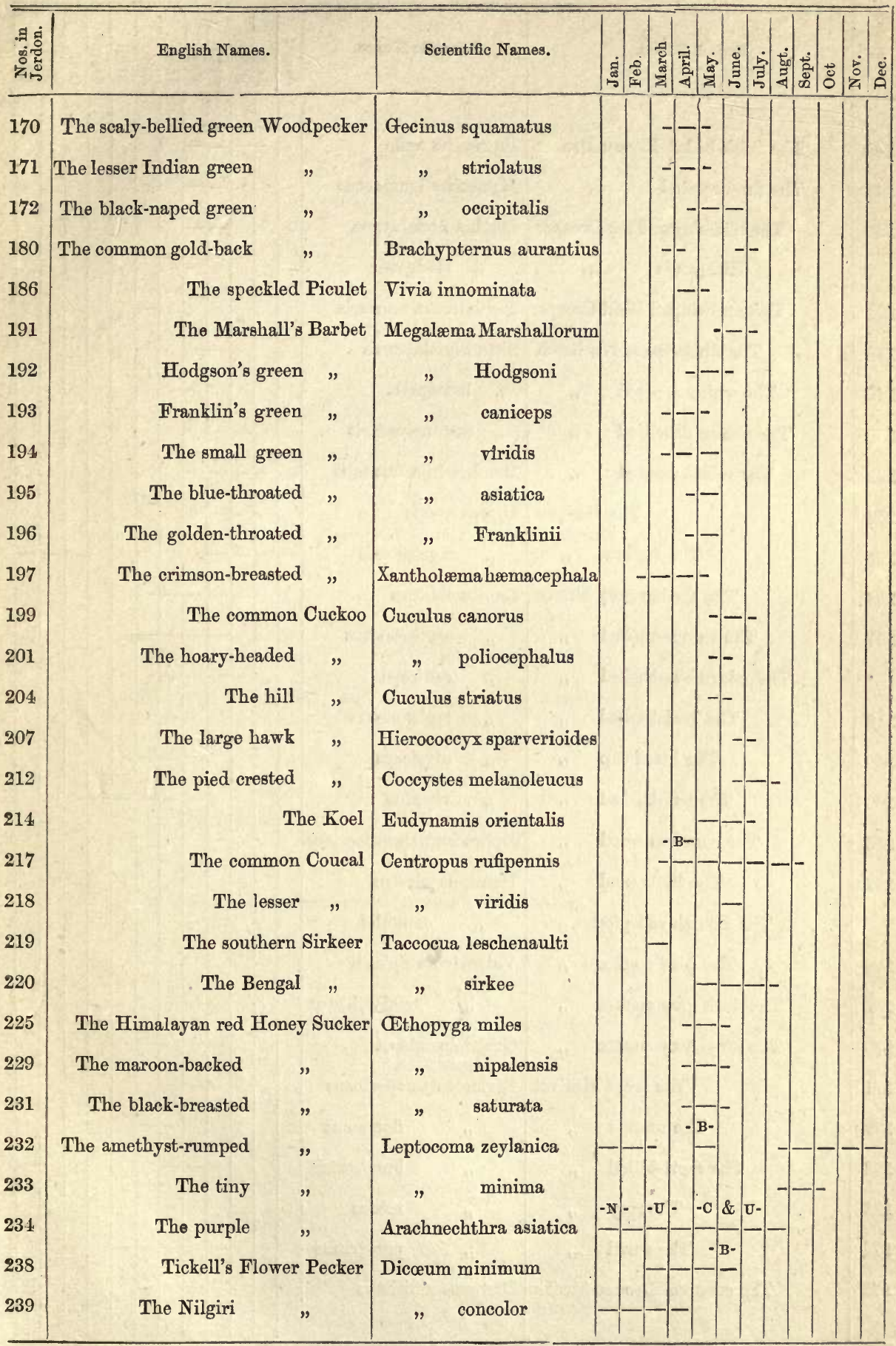




\begin{tabular}{|c|c|c|c|c|c|c|c|c|}
\hline | & English Names. & Scientific Names. & | & & 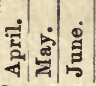 & 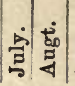 & \begin{tabular}{l|l}
$\dot{0}$ \\
$\dot{0}$ \\
$\dot{0}$
\end{tabular} & : \\
\hline
\end{tabular}

\section{The thick-billed Flower Pecker Piprisoma agile}

The fire-breasted " Myzanthe ignipectus The Himalayan Tree Creeper Hodgson's " " Hodgsoni The red-winged Wall Creeper Tichodroma muriaria The white-tailed Nuthatch The white-cheeked "

The chestnut-bellied " The velvet-fronted "

The Hoopoe The Indian "

The Indian grey Shrike

\section{The rufous-backed "}

Thepale rufous-backed "

The grey-backed "

The black cap "

The bay-backed "

The common wood "

The little pied "

The Himalayan pied "

The pied cuckoo "

The dark grey cuckoo "

The large grey cuckoo "

The large Minivet

The orange "

The short-billed "

The rosy "

The small . ,

The common Drongo Shrike
Sitta himalayensis

" leucopsis

, castaneiventris

Dendrophila frontalis

Upupa epops

" nigripennis

Lanius lahtora

" erythronotus

" caniceps

, tephronotus

" nigriceps

" vittatus

Tephrodornis ponticeriana

Hemipus picatus

" capitalis

Volrocivora Sykesii

" melaschistus

Graucalus macei

Pericrocotus speciosus

, flammeus

, brevirostris

, roseus

, peregrinus

Dicrurus albirictus

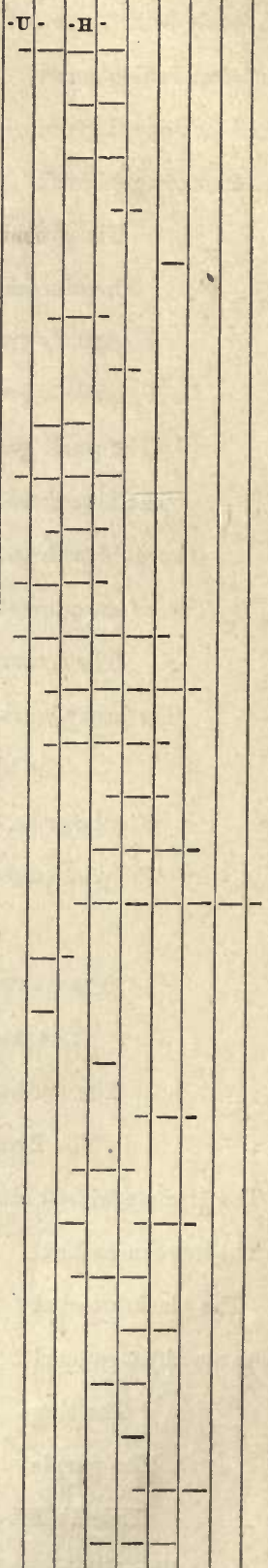




\begin{tabular}{|c|c|c|c|c|c|c|c|c|c|c|}
\hline 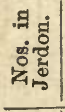 & English Names. & & Scientific Names. & 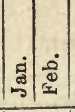 & 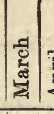 & & & & 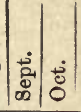 & 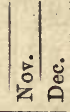 \\
\hline 280 & \multicolumn{2}{|c|}{ The long-tailed drongo Shrike } & Dicrurus longicaudatus & & & & & & & \\
\hline & Walden's & ” & " waldeni & & & & - & & & \\
\hline 281 & The white-bellied & $"$ & " cœrulescens & & & & - & & & \\
\hline 282 & The bronzed & " & Chaptia œnea & & & - & - & & & \\
\hline 283 & The oar-tailed & " & Bhringa remifer & & & t & - & & & \\
\hline $284^{\circ}$ & The Northern racket-tailed & $"$ & Edolius paradiseus & & & - & & & & \\
\hline 286 & The hair-crested & " & Chibia hottentota & & & - & - & & & \\
\hline 287 & \multicolumn{2}{|c|}{ The ashy swallow Shrike } & Artamus fuscus & & & - & & & & \\
\hline 288 & \multicolumn{2}{|c|}{ The paradise Flycatcher } & Tchitrea paradisei & & & & - & - & & \\
\hline 290 & The black-naped azure & ” & Myiagra azurea & & & & $-1-$ & - & & \\
\hline 291 & \multicolumn{2}{|c|}{ The white-throated Fantail } & Leucocerca fuscoventris & & & & - & - & & \\
\hline 292 & \multicolumn{2}{|l|}{ The white-browed } & " aureola & & & & - & - & & \\
\hline 293 & \multicolumn{2}{|l|}{ The white-spotted } & " pectoralis & & & - & $-1-$ & - & & \\
\hline 294 & \multicolumn{2}{|l|}{ The yellow-bellied } & Chelidorhynx hypoxanthus & & & - & - & & & \\
\hline 295 & \multicolumn{2}{|c|}{ The grey-headed Flycatcher } & Cryptolopha cinereocapilla & & & - & - & - & & \\
\hline 296 & The sooty & $"$ & Hemichelidon fuliginosa & & & & - & & & \\
\hline 300 & The black and orange & $"$ & Ochromela nigrorufa & & & - & . & & & \\
\hline 301 & The verditer & " & Eumyias melanops & & & - & - & & & \\
\hline 302 & The Nilgiri blue & ” & " albicaudata & & & & & & & \\
\hline 304 & \multicolumn{2}{|c|}{ The blue-throated Redbreast } & Cyornis rubeculoides & & & - & - & & & \\
\hline 305 & The southern blue & " & " banyumas & & & t & - & & & \\
\hline 306 & Tickell's blue & $"$ & " tickelliæ & & & - & - & & & \\
\hline 310 & \multicolumn{2}{|c|}{ The white-browed blue Flycatcher } & Muscicapula superciliaris & & & - & - & & & \\
\hline 314 & The fairy & $"$ & Niltava sundara & & & - & & & & \\
\hline 315 & McGregor's fairy & ” & " macgrigorico & & & - & - & & & \\
\hline 316 & The great fairy & $"$ & $" \quad$ grandis & & & - & - & & & \\
\hline 320 & The slaty & ” & Siphia leucomelanura & & & & - & & & \\
\hline 321 & The rufous-breasted & $"$ & " superciliaris & & & & - & & & \\
\hline & The grey robin & " & Erythrosterna parva & & & & - & & & \\
\hline 324 & white-tailed robin & $"$ & " hyperythra & & & - & - & & & \\
\hline
\end{tabular}




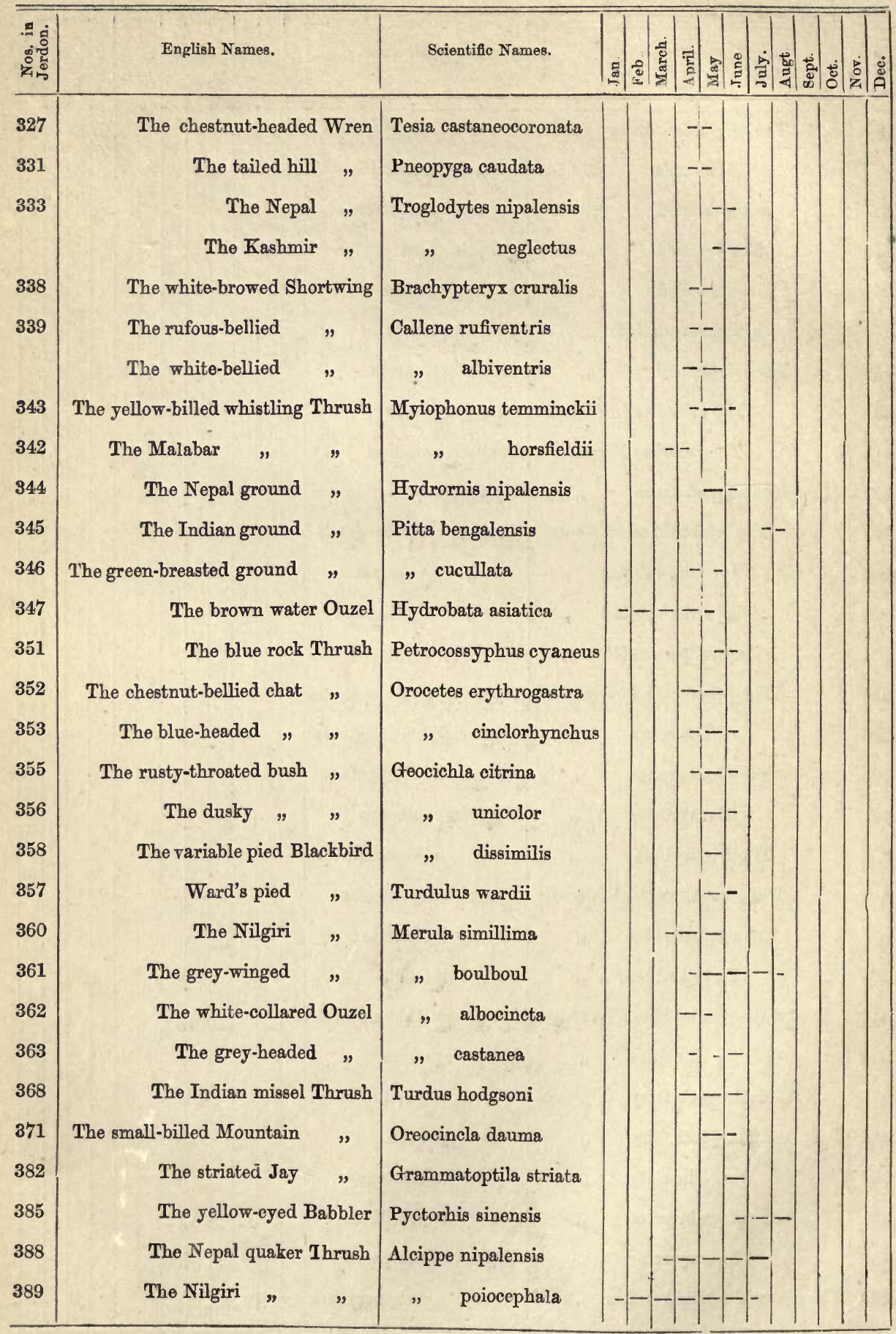




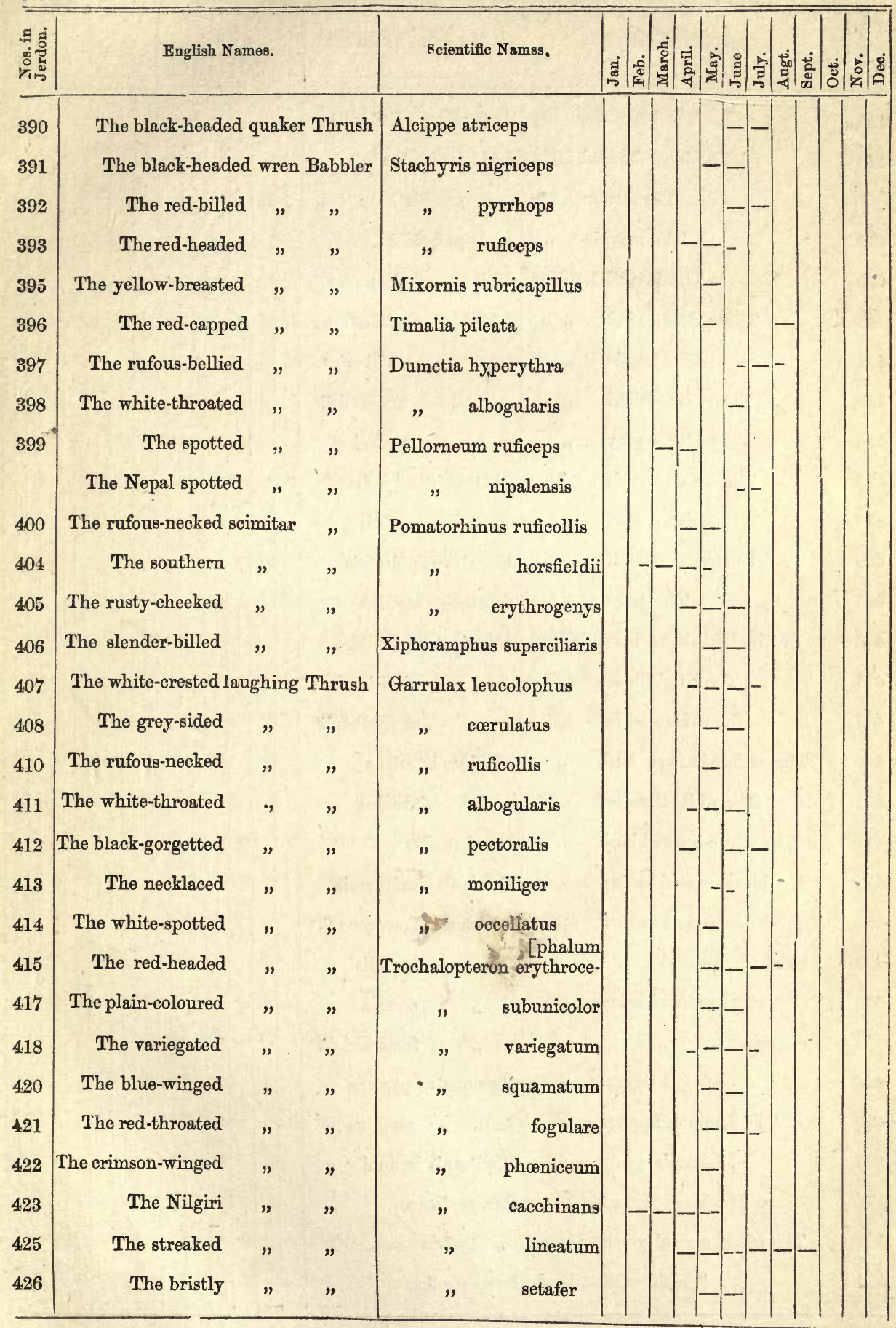


LIST OF BIRDS KNOWN TO BREED IN INDIA,

\begin{tabular}{|c|c|c|c|c|c|c|c|c|c|c|}
\hline 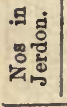 & English Names. & & Scientiffe Names. & 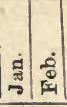 & & & & & 客 & 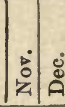 \\
\hline 428 & \multicolumn{2}{|c|}{ The hoary Barwing } & Actinodura nipalensis & & & & - & & & \\
\hline 429 & \multicolumn{2}{|c|}{ The black-headed Sibia } & Sibia eapistrata & & & & & & & \\
\hline & The Assam & $"$ & " gracilis & & & & & & & \\
\hline 430 & The magpio & $"$ & " picaoides & & & & & & & \\
\hline 432 & The Bengal B & Babbler & Malacocercus canorus & & & & & & & \\
\hline 433 & The white-headed & $"$ & $" \quad$ griseus & & & & 5 & & & \\
\hline 434 & The jungle & $"$ & " malabaricus & & & & & & & \\
\hline 435 & The rufous-tailed & $"$ & $" \quad$ somervillii & & & & -- & & & \\
\hline 436 & The large grey & $"$ & " malcolmi & & & & & & & \\
\hline 438 & The striated bush & $"$ & Chattarrhøea caudata & & & & & & & \\
\hline 439 & The striated reed & $"$ & " earlii & & & & & & & \\
\hline 440 & The striated marsh & " & Megalurus palustris & & & & & & & \\
\hline 441 & The grass & $"$ & Chætornis striatus & & & & & & & \\
\hline 444 & The Himalayan black I & Bulbul & Hypsipetes psaroides & & & & & & & \\
\hline 445 & The Nilgiri black & $"$ & . " nilgiriensis & & & & & & & \\
\hline 447 & The rufous-bellied & $"$ & " mcClellandi & & & & & & & \\
\hline 450 & The yellow-browed bush & $"$ & Criniger ictericus & & & & & & & \\
\hline 451 & The white-throated & $"$ & , flaveolus & & & & & & & \\
\hline 452 & The white-browed bush & " & Ixos luteolus & & & & & & & \\
\hline 456 & The black-crested yellow & $"$ & Rubigula flaviventris & & & & & & & \\
\hline 458 & The white-cheeked crested & $"$ & Otocompsaleucogenys & & & & & & & \\
\hline 459 & The white-eared " & $"$ & " leucotis & & & & & & & \\
\hline 460 & The red-whiskered & $"$ & $" \quad$ emeria & & & & & & & \\
\hline & The southern & $"$ & $" \quad$ fuscicaudata & & & & - & & & \\
\hline 461 & The common Bengal & $"$ & Pycnonotus pygœus & & & & & U. & & \\
\hline 462 & The common Madras & $"$ & $" \quad$ pusillus & & & B. & & $\mathrm{c}-$ & & \\
\hline 463 & Jerdon's green & $"$ & Phyllornis jerdoni & & & & & & & \\
\hline 467 & The black-backed & $”$ & Iora zeylanica & & & & & B- & & \\
\hline 468 & The white-winged green & $"$ & " typhia & & & & & & & \\
\hline 469 & The fairy Blue & Bird & Irena puella & & & & & & & \\
\hline
\end{tabular}




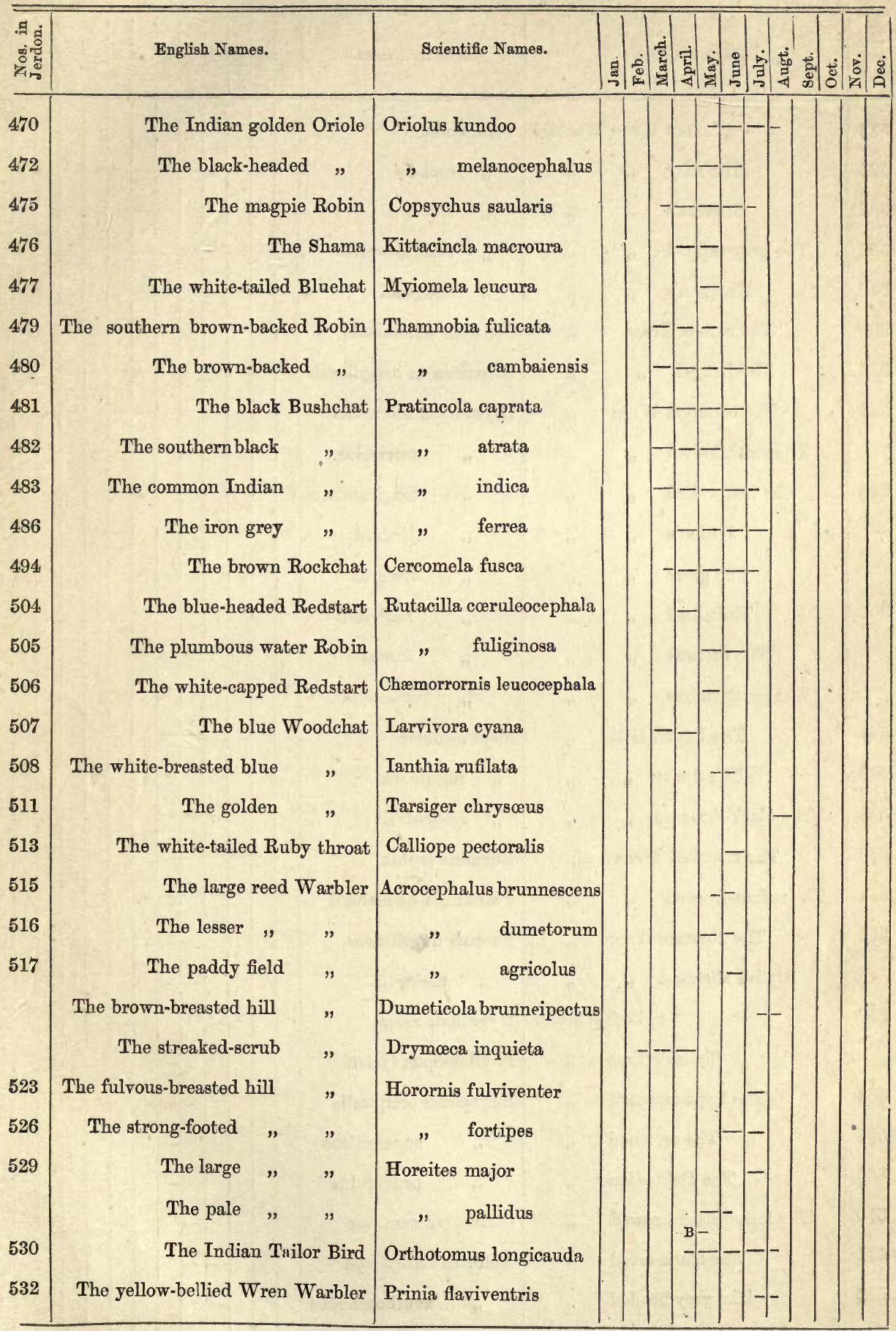




\begin{tabular}{|c|c|c|c|c|c|c|c|c|c|c|c|c|}
\hline ". & English Names. & & Scientiflc Names. & & 这 & & & & & & D. & 它 \\
\hline 533 & Adams's Wren & arbler & Prinia adamsi & & & & & & & & & \\
\hline 534 & The ashy " & $"$ & " socialis & & & & - & - & & - & & \\
\hline 535 & Stewart's " & $"$ & " stewarti & & & & & & & & & \\
\hline 537 & The grey-capped & $"$ & " cinereocapilla & & & & & & & & & \\
\hline 538 & Hodgson's & $\eta$ & " hodgsoni & & & & & & & & & \\
\hline 539 & The rufous Grass & $"$ & Cisticola schœnicola & & & & & - & & & - & \\
\hline 542 & The Bengal ", & " & Graminicola bengalensis & & & & & & & & & \\
\hline 543 & The common Wren & " & Drymoipus inornatus & & & & & & & & & \\
\hline & The earth brown " & $"$ & $" \quad$ terricolor & & & & & & & & & \\
\hline 544 & The long-tailed & " & " longicaudatus & & & & & & & & & \\
\hline & Jerdon's & 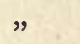 & $" \quad$ jerdoni & & & & & & & & & \\
\hline & The great & $"$ & " insignis & & & & & & & & & \\
\hline 546 & The allied & $"$ & neglectus & & & & & & & & & \\
\hline & The fuscous & $"$ & fuscus & & & & & & & & & \\
\hline & The great rufous & $"$ & $" \quad$ rufescens & & & & & & & & & \\
\hline 547 & The brown Hill & , & Suya criniger & & & & & & & & & \\
\hline 548 & The dusky ", & ” & $"$ fuliginosa & & & & & & & & & \\
\hline 549 & The black-throated , & , & " atrogularis & & & & & & & & & \\
\hline 550 & The streaked Wren & $"$ & Burnesia lepida & & & & & & & & & \\
\hline 551 & The rufous-fronted ", & ” & Franklinia buchanani & & & & & & & & & \\
\hline 552 & The aberrant Tree & , & Neornis flavolivacea & & & & - & & & & & \\
\hline & Blyth's aberrant " & $\eta$ & $" \quad$ assimilis & & & & & & & & & \\
\hline 553 & Sykes' & arbler & Hyppolais rama & & & & & & & & & \\
\hline & Tytler's Tree & $\eta$ & Phylloscopus tytleri & & & & & & & & & \\
\hline 563 & The large-crowned & 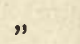 & Reguloides occipitalis & & & & & & & & & \\
\hline 565 & The crowned & $"$ & superciliosus & & & & & & & & & \\
\hline 566 & The Dalmatian & 川 & proregulus & & & & & - & & & & \\
\hline 570 & The lesser black-browed & $"$ & Culicepeta cantator & & & & - & & & & & \\
\hline 571 & The black-eared & " & Abrornis schisticeps & & & & - & & & & & \\
\hline 572 & The grey-headed & " & " xanthoschistus & & & _ & & & & & & \\
\hline
\end{tabular}




\begin{tabular}{|c|c|c|c|c|c|c|c|c|c|c|}
\hline 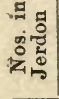 & English Names. & Scientific Names. & & & 㤩 & & 官 & 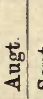 & \begin{tabular}{c|c}
0 \\
\\
$\infty$
\end{tabular} & \begin{tabular}{l|l}
$\dot{0}$ \\
$\vdots$ \\
\end{tabular} \\
\hline & The grey-faced Warbler & Abrornis chloronotus & & & & - & & & & \\
\hline 573 & The white-browed " & " albosuperciliaris & & & & - & & & & \\
\hline & The chestnut-headed & " castaneiceps & & & & - & & & & \\
\hline 580 & The Indian golden-crested Wren & Regulus himalayensis & & & & - & & & & \\
\hline 582 & The Indian Whitethroat & Sylvia affinis & & & & - & & & & \\
\hline 584 & The western-spotted Forktail & Henicurus maculatus & & & & - & & & & \\
\hline 586 & The slaty-backed " & $" \quad$ schistaceus & & & & & - & & & \\
\hline 587 & The little " & scouleri & & & & & & & & \\
\hline & The eastern-spotted & guttatus & & & & - & & & & \\
\hline 589 & The Indian pied Wagtail & Motacilla maderaspatana & & & & $1-$ & & & & - \\
\hline 590 & The white-faced & $" \quad$ luzionensis & & & & - & & & & \\
\hline 592 & The grey and yellow & $" \quad$ melanope & & 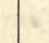 & & - & & & & \\
\hline & The black-backed yellow-headed ,, & Budytes calcaratus & & & & & & & & \\
\hline 596 & The Indian Pipit & Anthus arboreus & & & & - & & & & \\
\hline 597 & The Tree " & " maculatus & & & & - & & & & \\
\hline 598 & The Nilgiri " & „ montanus & & & & - & & & & \\
\hline 600 & The Indian Tit Lark & " rufulus & & & & & - & & & \\
\hline 605 & The ruddy Pipit & " rosaceus & & & & - & & & & \\
\hline 603 & The Nilgiri Tit Lark & Agrodroma cinnamomea & & & & & & & & \\
\hline 604 & The brown Rock Pipit & " griseorufescens & & & . & & - & & & \\
\hline 606 & The upland " & Heterura sylvana & & & & - & - & & & \\
\hline 607 & The purple Thrush Tit & Cochoa purpurea & & & & - & & & & \\
\hline 608 & The green & " viridis & & & & - & & & & \\
\hline 609 & The red-winged Shrike, & Pteruthius erythropterus & & & & - & & & & \\
\hline 614 & The red-billed Hill ,' & Leiothrix luteus & & & & & & & & \\
\hline 615 & The silver-eared " " & " argentarius & & & & - & & & & \\
\hline 616 & The stripe-throated ", , & Siva strigula & & & & - & & & & \\
\hline 617 & The blue-winged " " & „ cyanouroptera & & & & - & & & & \\
\hline 618 & The red-tailed ", " & Minla ignotincta & & & & 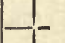 & & & & \\
\hline 619 & The chestnut-headed $"$, & " castaneiceps & & & & - & 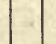 & & & \\
\hline
\end{tabular}




\begin{tabular}{|c|c|c|c|c|c|c|c|c|c|c|c|}
\hline | & English Names. & Scientific Names. & 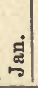 & & & & & & & & : \\
\hline 621 & The golden breasted Hill Tit & Proparus chrysœus & & & & & & & & & \\
\hline 623 & The yellow naped " " & Ixulus flavicollis & & & & & & & & & \\
\hline 624 & The rusty headed " " & " occipitalis & & & & & - & & & & \\
\hline 626 & The stripe throat crested " " & Yuhina gularis & & & & & - & & & & \\
\hline 628 & The black-chinned " " & " nigrimentum & & & & & - & & & & \\
\hline 629 & The fire-tailed " " & Myzornis pyrrhoura & & - & $0 \mathrm{~N}$ & & & & & & \\
\hline 631 & The Indian white-eyed ," & Zosterops palpebrosus & & & 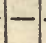 & & & & & & \\
\hline 633 & The firecap " & Cephalopyrus flammiceps & & & - & - & & & & & \\
\hline 634 & The red-capped , & Egithaliscus erythrocephalus & & - & - & & & & & & \\
\hline 638 & The crested-black , & Lophophanes melanolophus & & & - & & & & & & \\
\hline 644 & The mountain " & Parus monticolus & trot & & & & & & & & \\
\hline 645 & The Indian grey " & " cinereus & & & - & & & & & & \\
\hline 647 & The yellow-cheeked " & Machlolophus xanthogenys & & & & & & & & & \\
\hline 654 & The rufous-breasted Accentor & Accentor strophiatus & & & & & - & & & & \\
\hline & Jerdon's " & $"$, jerdoni & & & & & & & & & \\
\hline 657 & The Raven & Corvus corax & & & & & & & & & \\
\hline 659 & The Indian earrion Crow & $"$ corone & & & & & & & & & \\
\hline 660 & The bow-billed Corby & " culminatus & & & & & & & & & \\
\hline 661 & The Himalayan " & $"$ intermedius & & & & & & & & & \\
\hline 663 & The common " & " impudicus & & & & & & & & & \\
\hline 665 & The Jackdaw & " monedula & & & & & & & & & \\
\hline 666 & The Himalayan Nutcracker & Nucifraga hemispila & & & - & & & & & & \\
\hline 668 & The Himalayan Magpie & Pica bottanensis & & - & & & & & & & \\
\hline 669 & The Himalayan Jay & Garrulus bispecularis & & & & & & & & & \\
\hline 670 & The black-throated " & " lanceolatus & & & & & & & & & \\
\hline 671 & The red-billed blue , & Urocissa occipitalis & & & & & & & & & \\
\hline 672 & The yellow-billed blue " & " flavirostris & & & & & & & & & \\
\hline 673 & The green ," & Cissa venatoria & & & & & & & & & \\
\hline 674 & The Indian Treepie & Dendrocitta rufa & & & & & & & & & \\
\hline 676 & The Himalayan & " himalayanus & & & & & & & & & \\
\hline
\end{tabular}




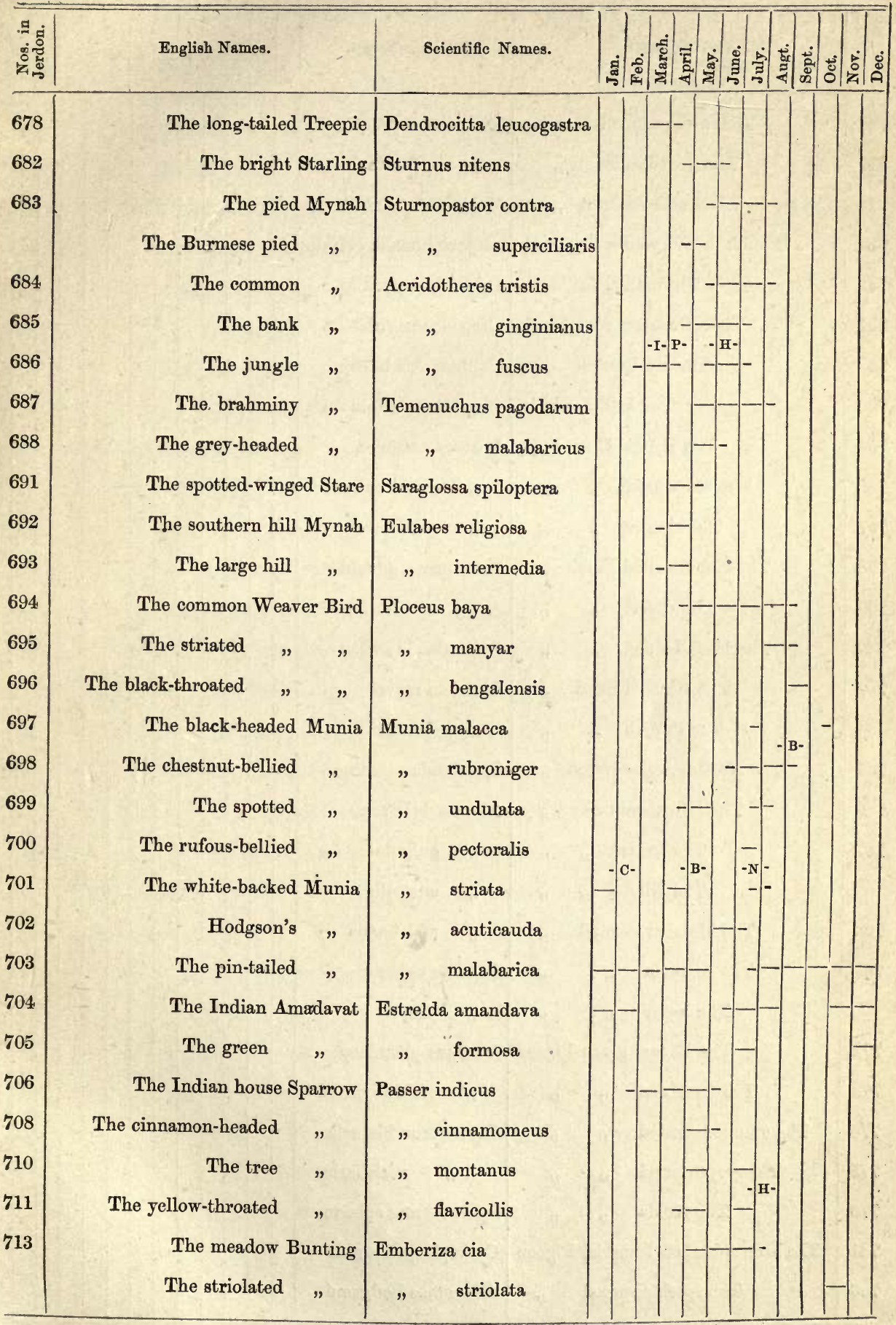




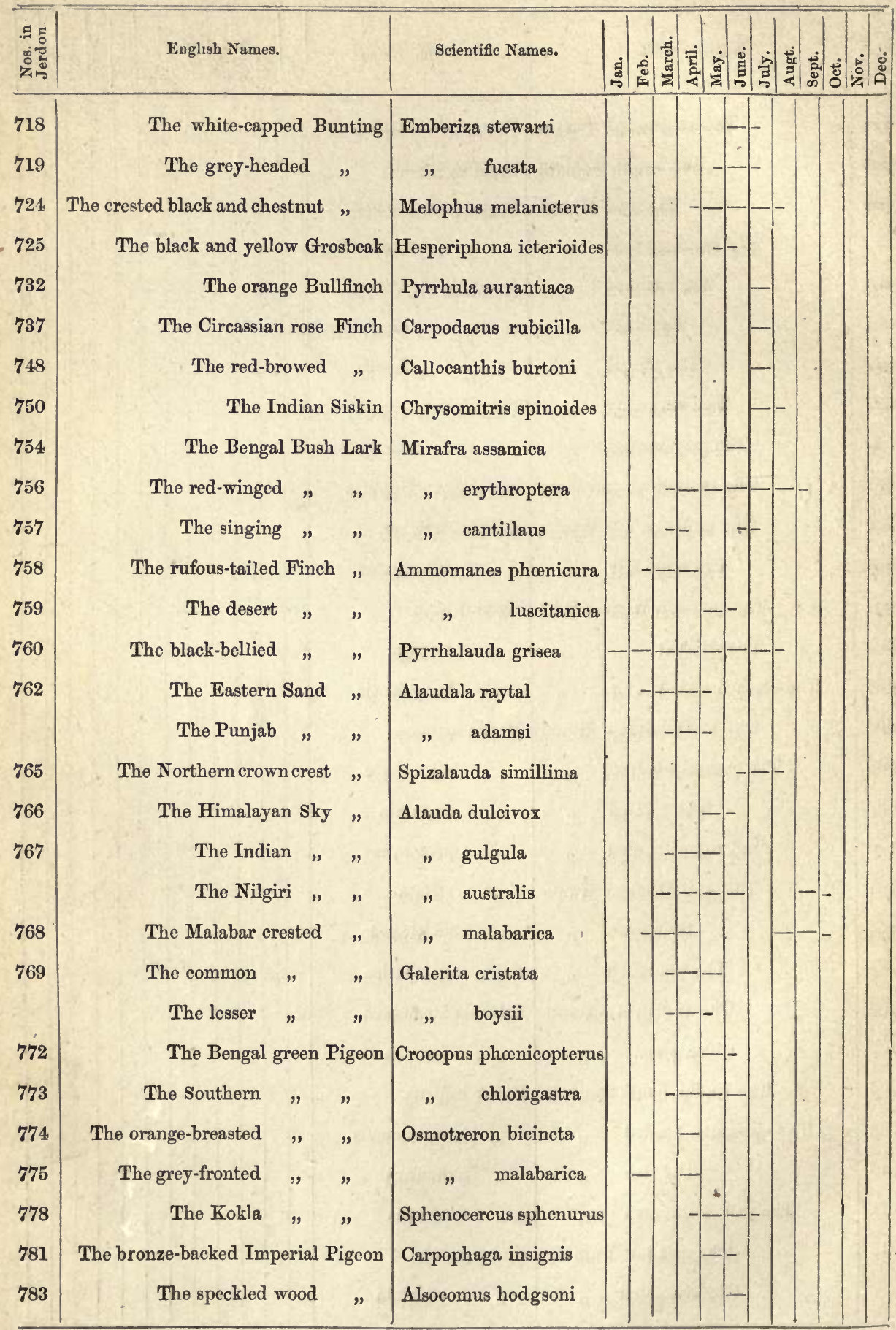




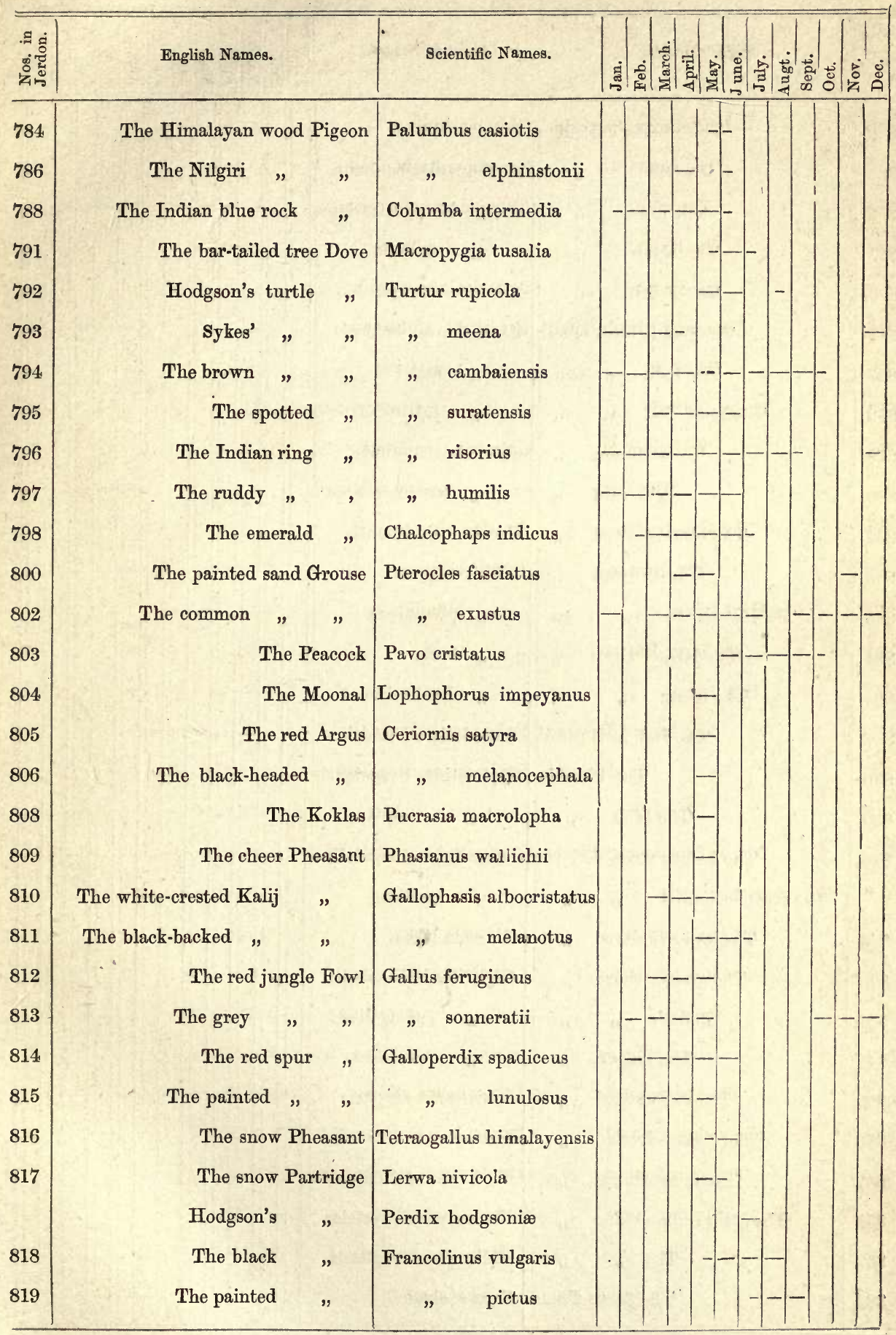




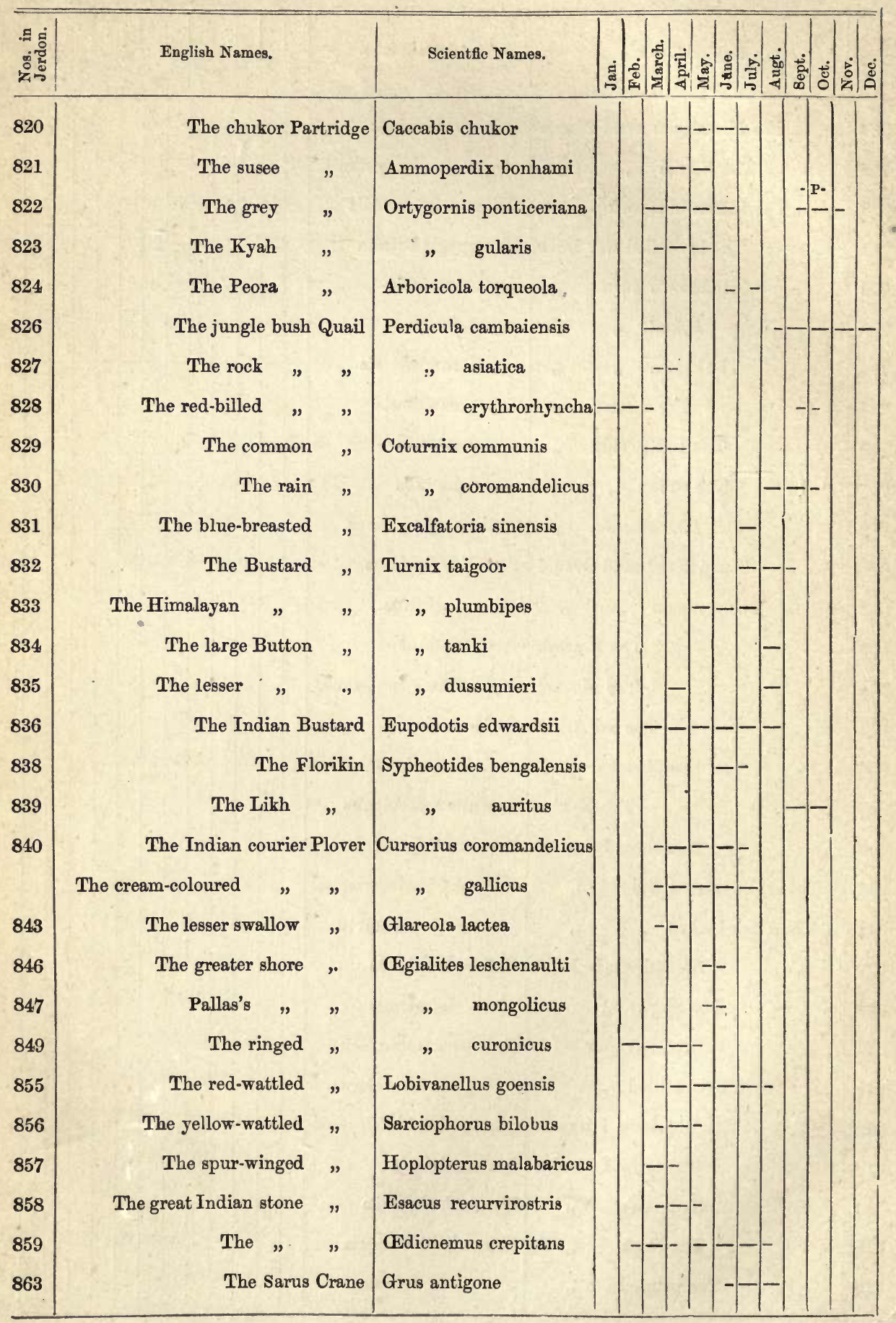




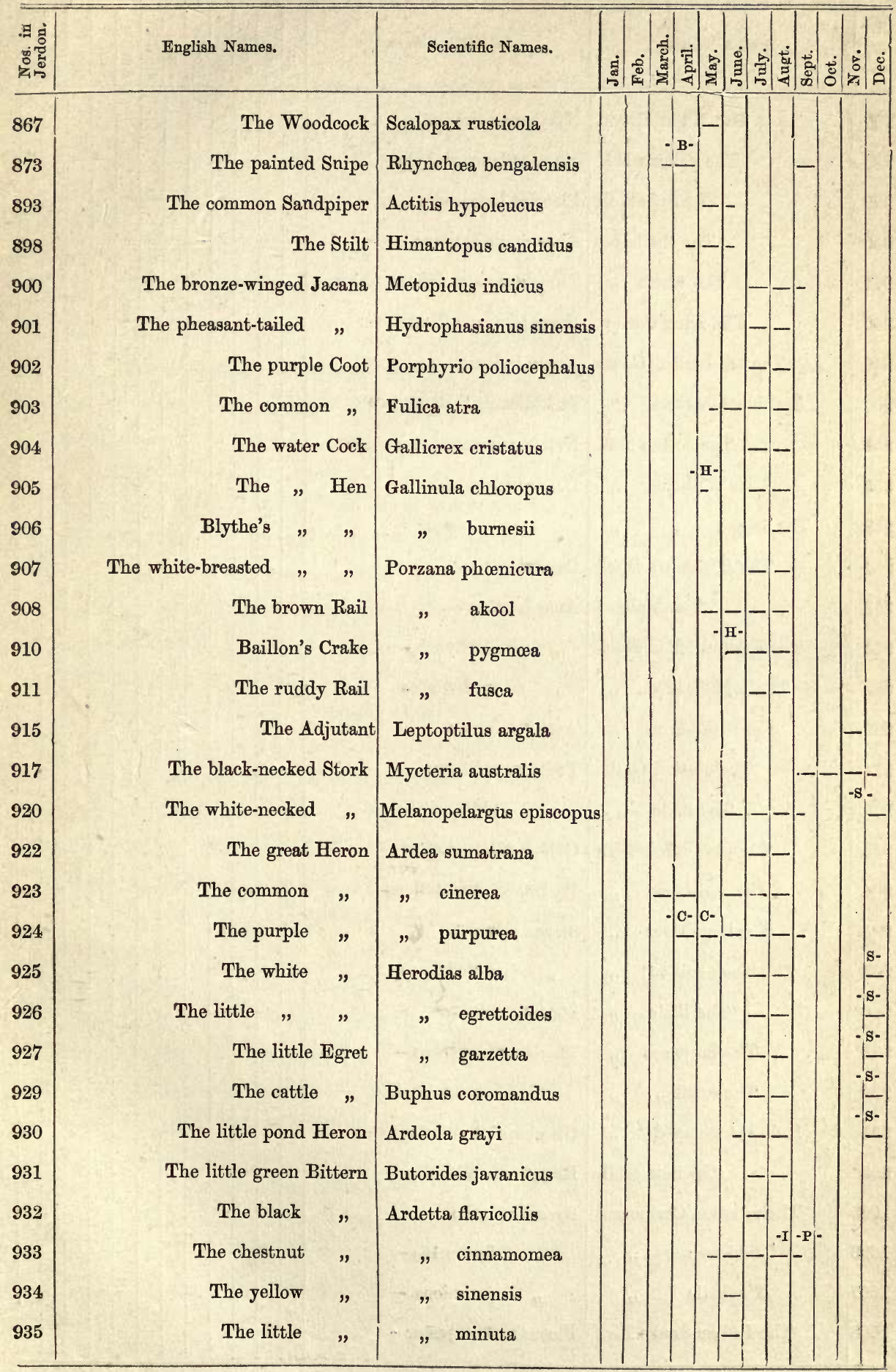


LIST OF BIRDS KNOWN TO BREED IN INDIA, \&C.

\begin{tabular}{|c|c|c|c|c|c|c|c|c|c|c|}
\hline 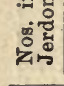 & English Names. & Scientific Names. & | & $\mid$ & 呅| & $\mid$ & & & $\dot{0}$ & 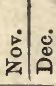 \\
\hline 937 & The Night Heron & Nycticorax griseus & & & - & & & & & \\
\hline 938 & The pelican Tbis & Tantalus leucocephalus & & & & & & & & \\
\hline 939 & The Spoonbill & Platalea leucorodia & & & & & & & & \\
\hline 940 & The shell Ibis & Anastomus oscitans & & & & & & & & \\
\hline 941 & The white " & Threskiornis melanocephalus & & & & & & & & \\
\hline 942 & The King Curlew & Geronticus papillosus & & & & & & - & & \\
\hline 949 & The bar-headed Goose & Anser indicus & & & - & & & & & \\
\hline 950 & The black-backed " & Sarkidiornis melanotus & & & & & - & & & \\
\hline 951 & The cotton Teal & Nettapus coromandelianus & & & & & & & & \\
\hline 952 & The Whistling " & Dendrocygna arcuata & & & & & & & & \\
\hline 953 & The large & . $" \quad$ major & & & & & & - & & \\
\hline 954 & The Brahminy Duck & Casarca rutila & & & - & & & & & \\
\hline 958 & The Mallard & Anas boschas & & & & & & & & \\
\hline 959 & The spotted-billed Duck & „, pœcilorhyncha & & & & & & - & & \\
\hline 960 & The pink-headed " & " caryophyllacea & & & & - & - & & & \\
\hline 969 & The white-eyed " & Aythya nyroca & & & & - & & & & \\
\hline 974 & The crested Grebe & Podiceps cristatus & & & 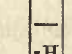 & & & & & \\
\hline 975 & The little " & „ philippensis & & & & & & & & \\
\hline 983 & The gull-billed Tern & Gelochelidon anglicus & & & & & & , & & \\
\hline 984 & The whiskered " & Hydrochelidon indicus & & & & & & & & \\
\hline 985 & The large river " & Sterna seena & & & & & & & & \\
\hline 987 & The black-bellied & " javanica & & - & - & & & & & \\
\hline 988 & The little & Sternula minuta & & & - & & & & & \\
\hline 989 & The large sea , & Thallaseus eristatus & & & & - & & & & \\
\hline 990 & The small , & " bengalensis & & & & - & & & & \\
\hline 991 & The little black-naped & Onochoprion melanauchen & & & & & & & & \\
\hline 995 & The Scissorbill & Rhynchops albicollis & & & & & & & & \\
\hline 1005 & The common Cormorant & Graculus carbo & & & & & & & & \\
\hline 1006 & The lesser & $"$ fuscicollis & & & & & & & & \\
\hline 1007 & The little & " javanicus & $\mid-8$ & & & & & & & \\
\hline 1008 & The Indian Snake Bird & Plotus melanogaster & & & & & & & & \\
\hline
\end{tabular}




\section{P A R T I I I.}

C ALENDAR.

THE columns of the accompanying calendar give the leading details for each month. The wording is necessarily brief, as the space is limited.

The first column gives the number in Jerdon's Hand-Book for reference. Where no number is given in this column, the bird has been added to the Indian list since Jerdon's book was published.

The next column gives the generally accepted English name. Jerdon's names have been adhered to in almost every case.

The third column is the scientific name. In this no alteration has been made, unless clearly proved to be necessary.

The next column "shape of nest."

And the one following " site of nest," need no comment.

The column headed "geographical range in breeding season" gives roughly the extent of country in which the bird is known to breed at one time or another, but it does not follow that it breeds throughout the whole of the range in that particular month.

The last column "particulars for the month" gives actual facts as ascertained by experience, leaving the reader to draw his own inference. Representative dates have been chosen so far as possible when more than one date was available ; for instance, if the season is beginning, the earliest date has been selected; and if the season is nearly over, the latest date has been taken. Similarly, in regard to localities, only one or two could be specified, and the same rule has been followed. Where the breeding is over a wide stretch of country, the two limits are given. Where any particular climate is more favorable, the typical place has been selected; of course, when only one nest has been found, the date of that is given, and there can be no selection, but the places and dates are records in every case of actual ascertained facts. 


\section{J A N UARY.}

JANUARY is in all parts of the country the month for the larger birds of prey. Of the fifty-six kinds of birds known to breed at this time, twenty-eight belong to this order (Raptores).

In the Himalayas, with the exception of a solitary instance of a nest of the brown water ouzel (Hydrobata asiatica), none but the nests of raptores have been found. Vultures, eagles, falcons, and kites are either building or laying, and as these birds are comparatively few in numbers, with great powers of fligbt, it is necessary to explore over a large extent of country to get many eggs; both birds and nests are conspicuous. Eyries can generally be marked down in the course of the morning's ride, and arrangements made afterwards for obtaining the eggs; a matter often of no small difficulty, as, whether the nest is on a ledge of the rock itself or in a tree, it is generally on the face of a precipice, which it requires both skill and nerve to surmount.

In the Punjab, besides the birds of prey, the raven, the striated bush babbler, and the dusky sand martin have eggs. Watch should be kept on all the large birds of prey, and every large solitary tree should be scanned, as it is on such trees that nests of eagles, vultures, \&c., will be found. These nests are conspicuous from a distance. I have often seen and noted them while passing along on a railway journey, returning when opportunity offered to examine the nest.

In the Nortin-West Provinces the Indian hoopoe, the sand martin, the pin-tailed munia, the blue rock pigeon, the common sand grouse, and the doves have eggs, as well as the vultures and eagles, and falcons and some of the owls.

In BENGAL, the sand martin is the only bird now breeding in any quantities, besides the birds of prey.

In Central India, the dusky crag martin, the munias and amadavats, and doves have eggs, besides the birds of prey which lay everywhere at this period.

In Sourn India, the large birds of prey are few in number, but the eggs of many other kinds may now be sought for. Some species of woodpeckers, martins, honey suckers, flower peckers, quaker thrushes, bulbuls, bluebirds, wagtails, finch larks, doves, quail, and water birds are already known to breed there at this season, and it is probable 


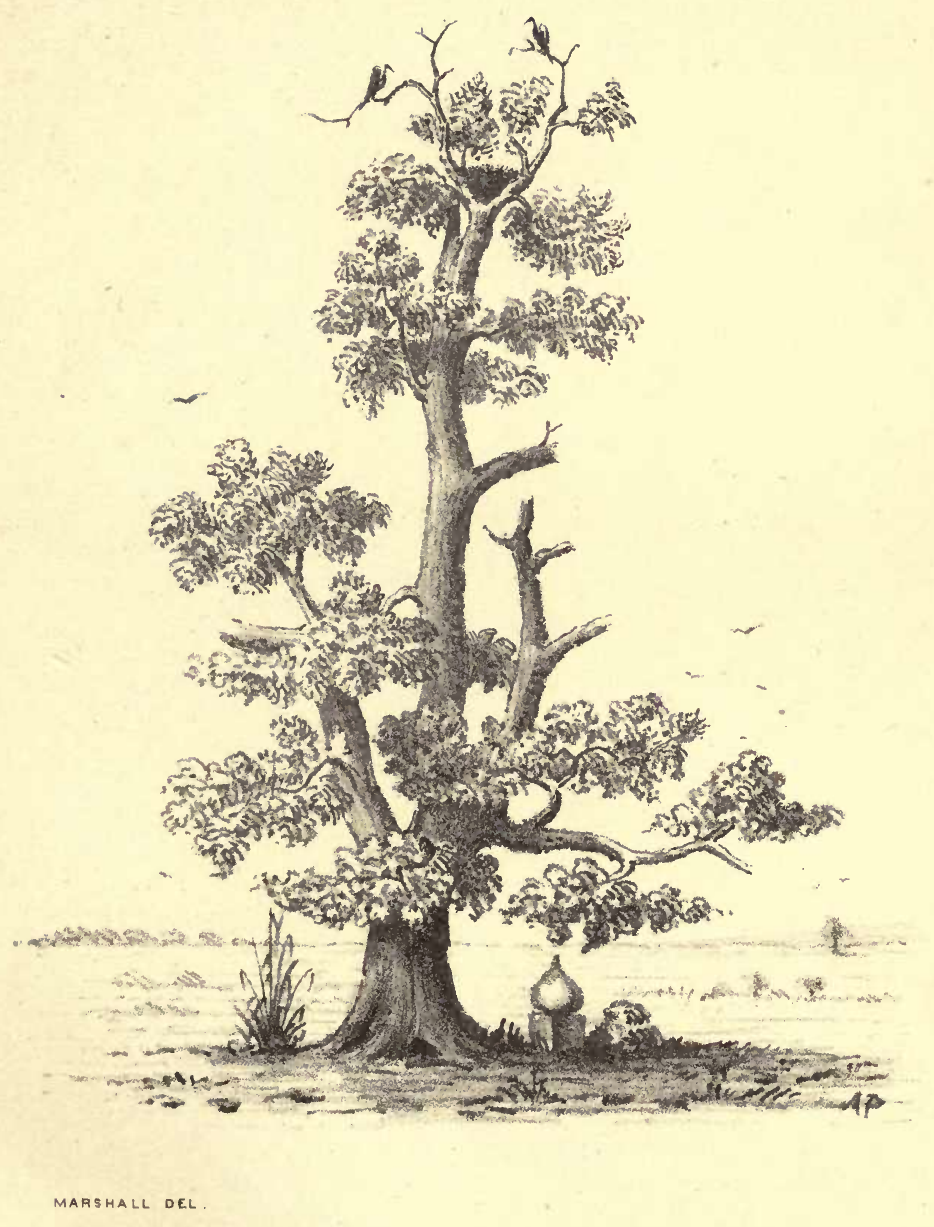

NEST OF THE KING VULTURE, 
a 
that further search will lead to the discovery of many others. Our knowledge of that part of India is comparatively very incomplete.

Besides the birds noted in the list, there are many that are known to lay early in February, and which may possibly sometimes lay in the end of January; at all events they will be building in the present month, and careful watch should be kept over their movements.

Among these may be noted in the Himalayas the black-capped falcon and the imperial eagle.

In the Punjab, the bay vulture and the imperial eagle, these are both rare birds, and few collections contain specimens of their eggs taken in India.

In the North-West Provinces, the spotted owlet begins to lay towards the end of the month, as also the little ringed plover, for which watch should be kept on the sands in the beds of big rivers, more especially on the flat sandy islands left by the receding floods.

In Central India, the bay vulture is building, and the grey partridge commences to pair.

In Southern India, the kestril commences building in the Nilgiris, also the red spur fowl, while in Travancore the booted eagle, the grey fronted green pigeon, and the grey jungle fowl are pairing and preparing their nests. 


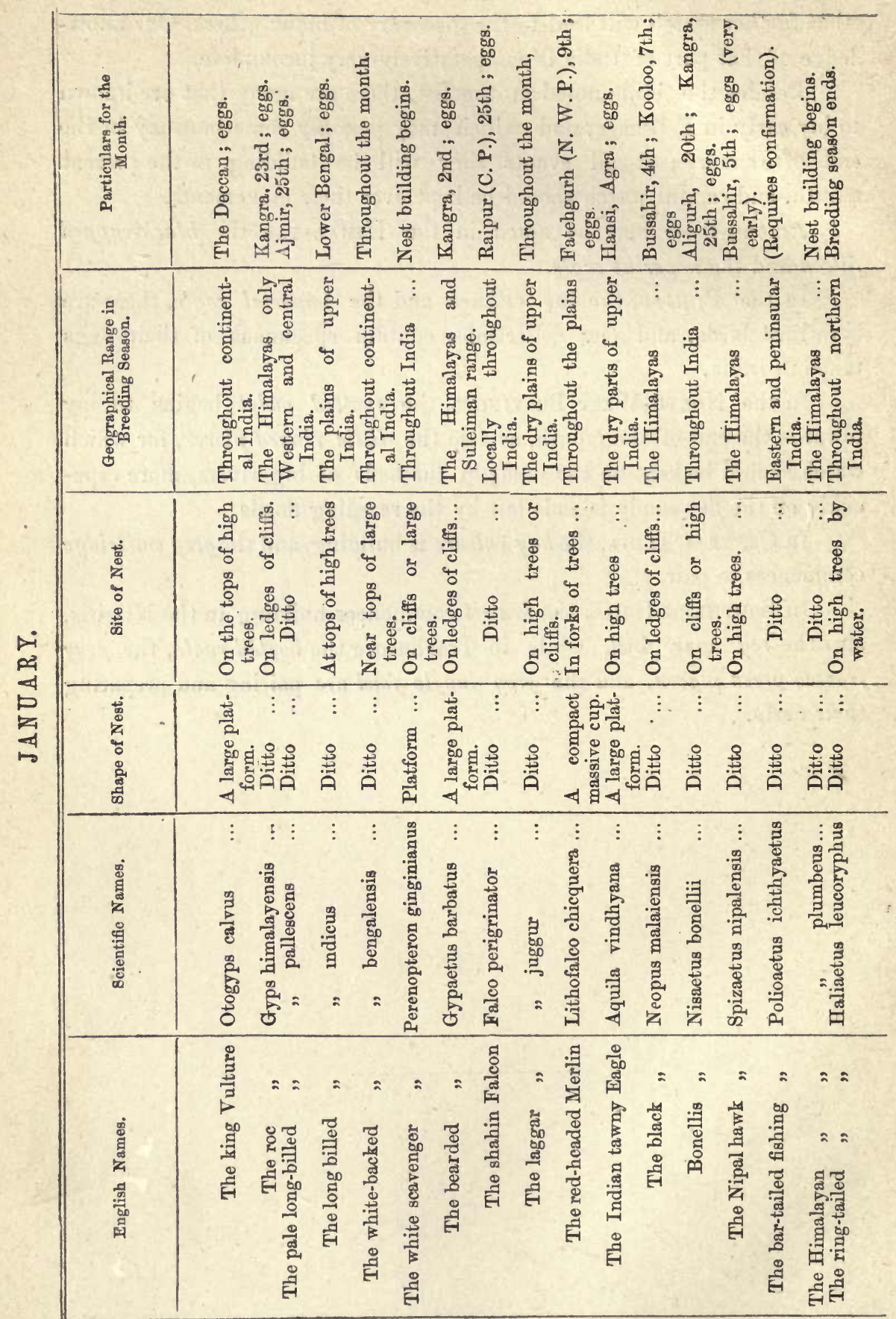

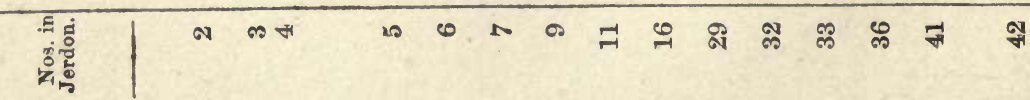




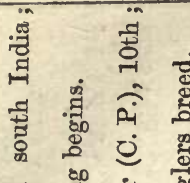

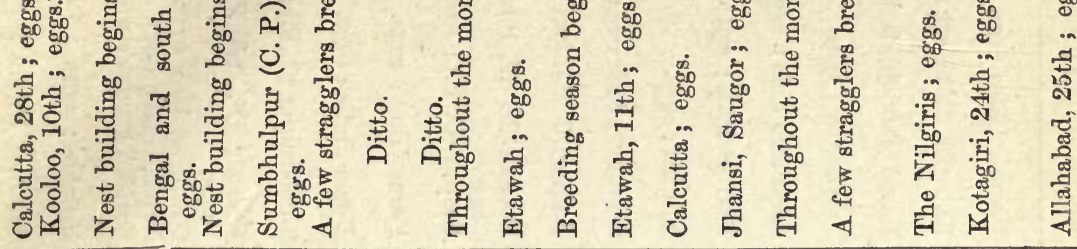

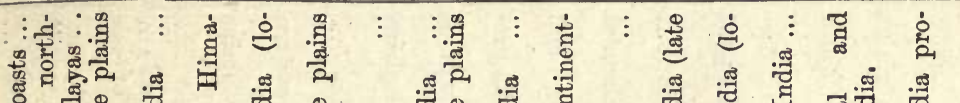

రొ

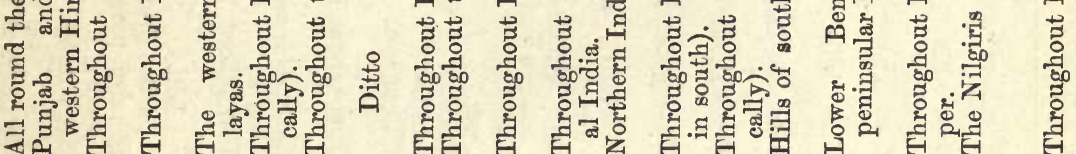

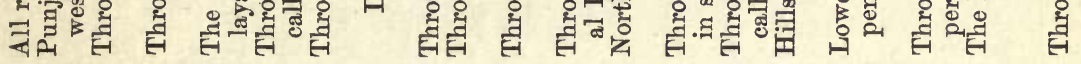

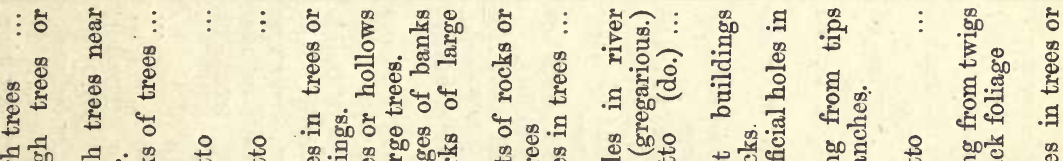

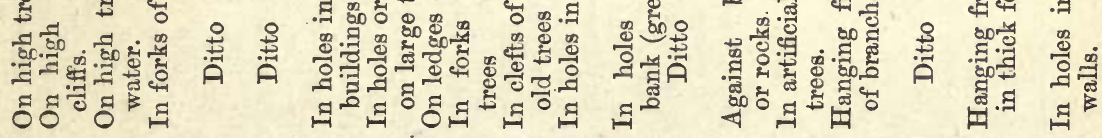

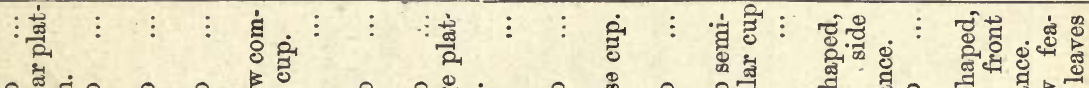

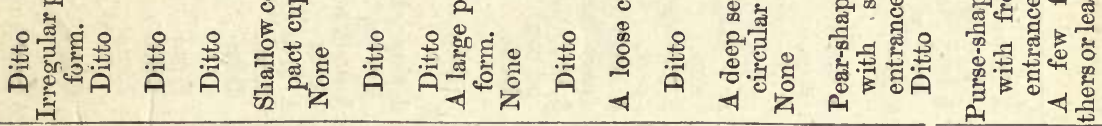

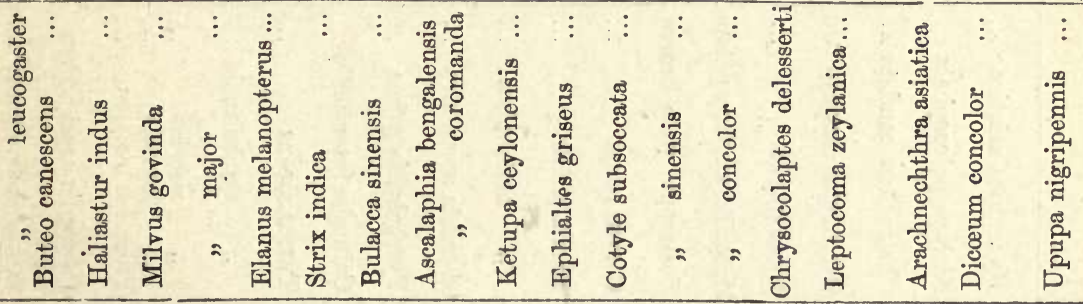

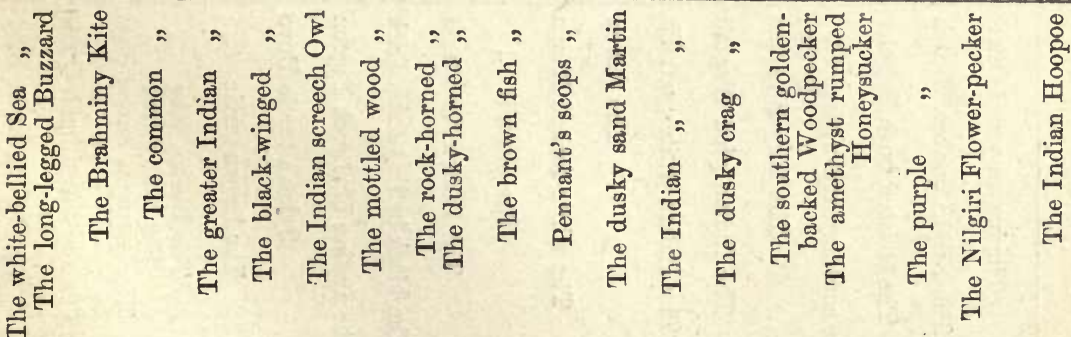

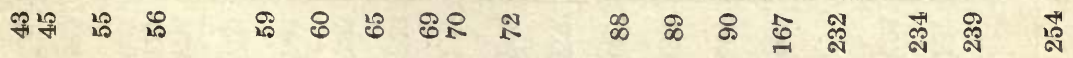




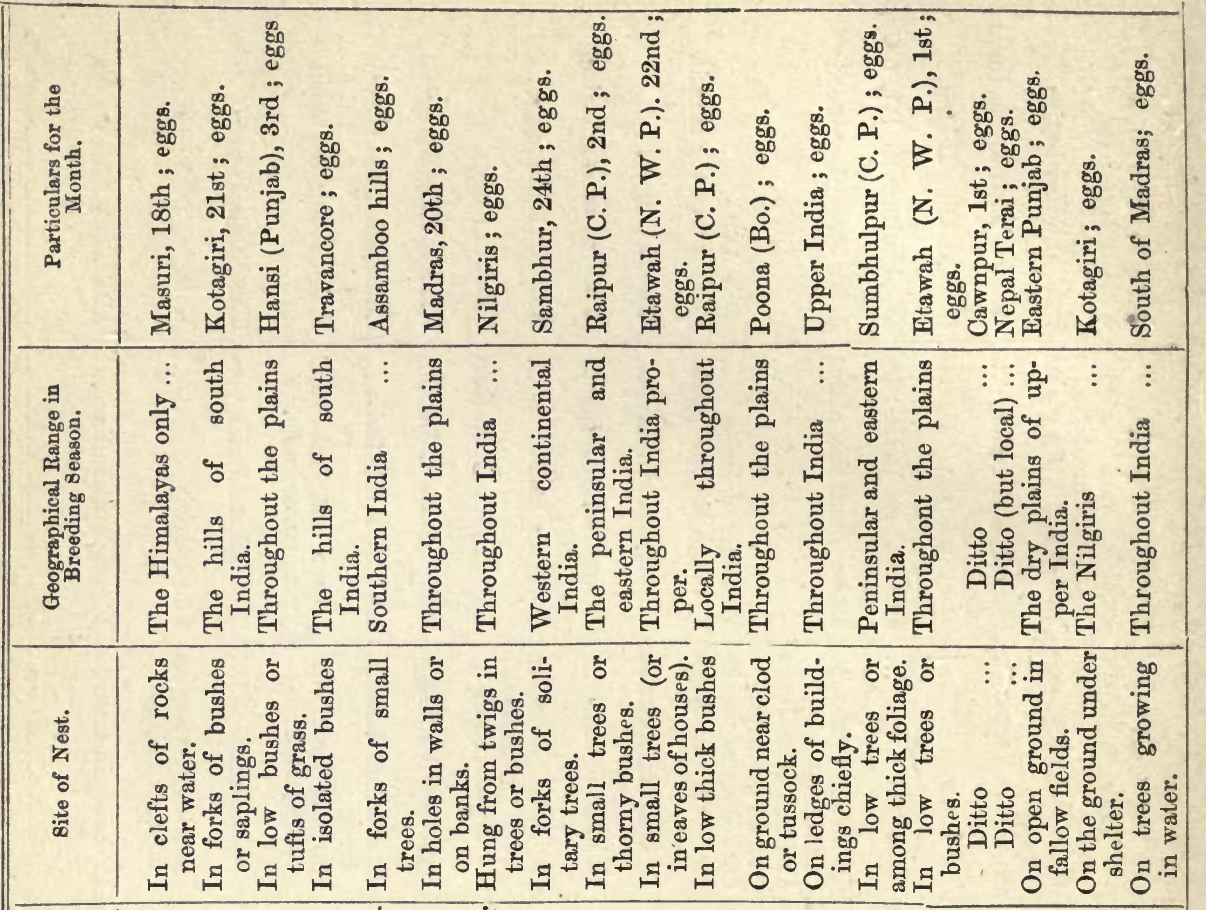

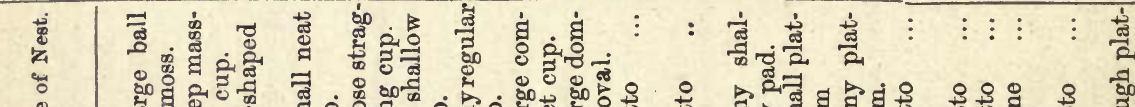

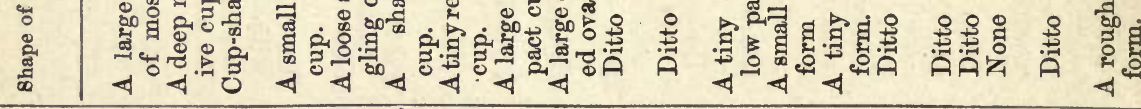

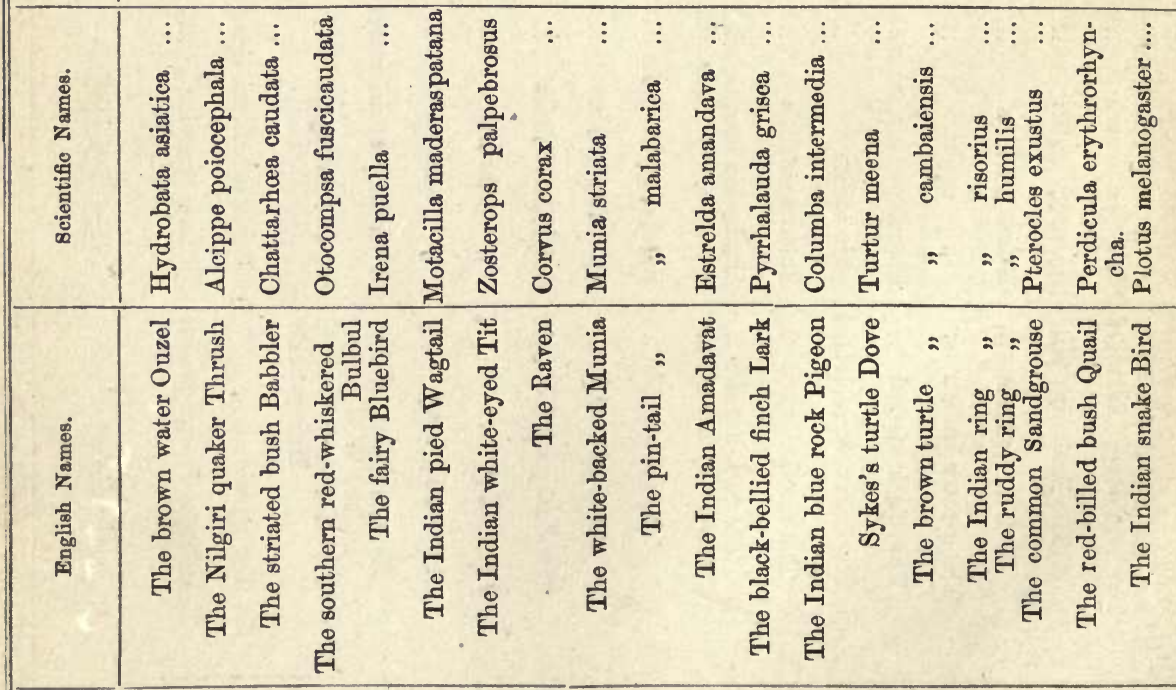

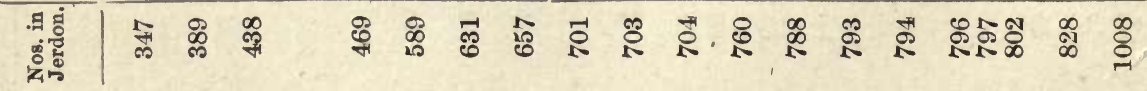





$$
\sigma
$$




\section{FEBRUARY.}

IN this month the birds of prey continue to lay, while other kinds commence. The eggs of several swallows and martins may now be found. Parrots, woodpeckers, and other climbing birds are pairing, and even commence excavating the holes for their nests. Several kinds of larks have eggs, others are pairing and building. Doves, of course, are breeding in this as in every other month. The spotted doves, which are more regular than the others, are commencing to build, and the jungle bush quail are pairing in all parts of the country.

In the Himalayas, the roc vulture, the lammergeyer, the blackcapped falcon, the hawk eagles, buzzards, kites, and water ouzels have eggs, while the large barred owlet and the common Indian bushchut are pairing and building throughout the range, and the redcapped tit and crested black tit begin to build in the eastern portions. The Himalayan magpie in all probability has eggs in this month.

In the Punjab, the vultures, falcons, eagles, Pennant's scops owls, the hoopoe, the grey shrike, the streaked scrub warbler, and the raven have eggs throughout the month, and the rufous grass warbler, the common quail, the big bustard, and in some places the common heron aro building their nests.

In the North-W EST Provinces, the laying season is fairly beginning. In addition to the vultures, falcons, eagles, \&c., no less than seven kinds of owls have eggs. Swallows and martins begin laying; so do also the parrots, the purple honey-sucker, the flower-peckers, the streaked wren warbler, the bow-billed corby, the house sparrow, the finch larks and sand larks, the emerald dove, the ringed plover and the stone plover : and besides these, the following kinds should be watched as they commence building their nests, and possibly laying also during this month:-the Indian scops owl, the palm swift, the rose-headed parroquet, the chestnut-bellied nuthatch, the common wcodshrike, the brown-backed rohin, the black bushchat, the common quail, and the spur-winged plover. The common heron too begins building in parts of Oudh, and the river terns and scissor bills are now congregating on the islands, where in the next month they will breed.

In BENGAL, the eggs of the long-billed vulture and white-bellied sea eagle and changeable hawk eagle, and brahminy kite may be taken. The common sand martin is still laying. The yellow-fronted wood- 
pecker has eggs, while the palm roof swift in the Garo hills, the redbreasted parroquet, the common woodshrike, and the red jungle fowl in the sub-Himalayan tracts are pairing off and preparing their nests. Here too the river terns and scissor bills are congregating.

In Central India, the vultures and the brahminy kite, probably also the owls, and whatever species of eagles are found there, have eggs still. The cliff swallow and dusky crag martin are hatching their first brood. The pied kingfisher, the crimson-breasted barbet, the amethyst rumped honey-sucker, the Indian amadavat, and the finch-larks have eggs throughout the month, while the painted spur forl, and probably also the flower-peckers, nuthatches, woodpeckers, parrots, larks, and some plovers are pairing. The river terns and scissor bills will alse probably congregate here too in this month.

In SoUtHerN INDIA, the breeding season is by this time further advanced than in the north. The kestril has eggs throughout the month in the Nilgiris. In the far south, eggs of the booted eagle may be taken, and also those of the common kite, the Nilgiri nightjar, the goldenbacked woodpecker, the Nilgiri flower-pecker, the velvet-fronted nuthatch, the quaker thrushes, babblers, laughing thrushes, bulbuls, and bluebirds throughout the peninsular. In the Nilgiris the eggs of the white-eyed hill tit may be found, and the Indian grey tit, the jungle mynah, the crested larks, green pigeons, doves, jungle forl, spur fowls, grey partridges, and bush quail are also sitting. In the extreme south the eggs of the snake bird, and possibly some other water birds, may still be found, but the season for them is virtually over. The following kinds are also commencing to pair and build their nests, and should be watched particularly towards the end of the month:The southern sirkeer, the little pied (flycatcher) shrike (Hemipus picatus), the spotted wren babbler, the black bulbul, the robins, bush chats, Nilgiri tit lark, long-tailed treepie, and Nilgiri sky lark. Of these latter the eggs have not as yet been taken before the beginuing of March. 


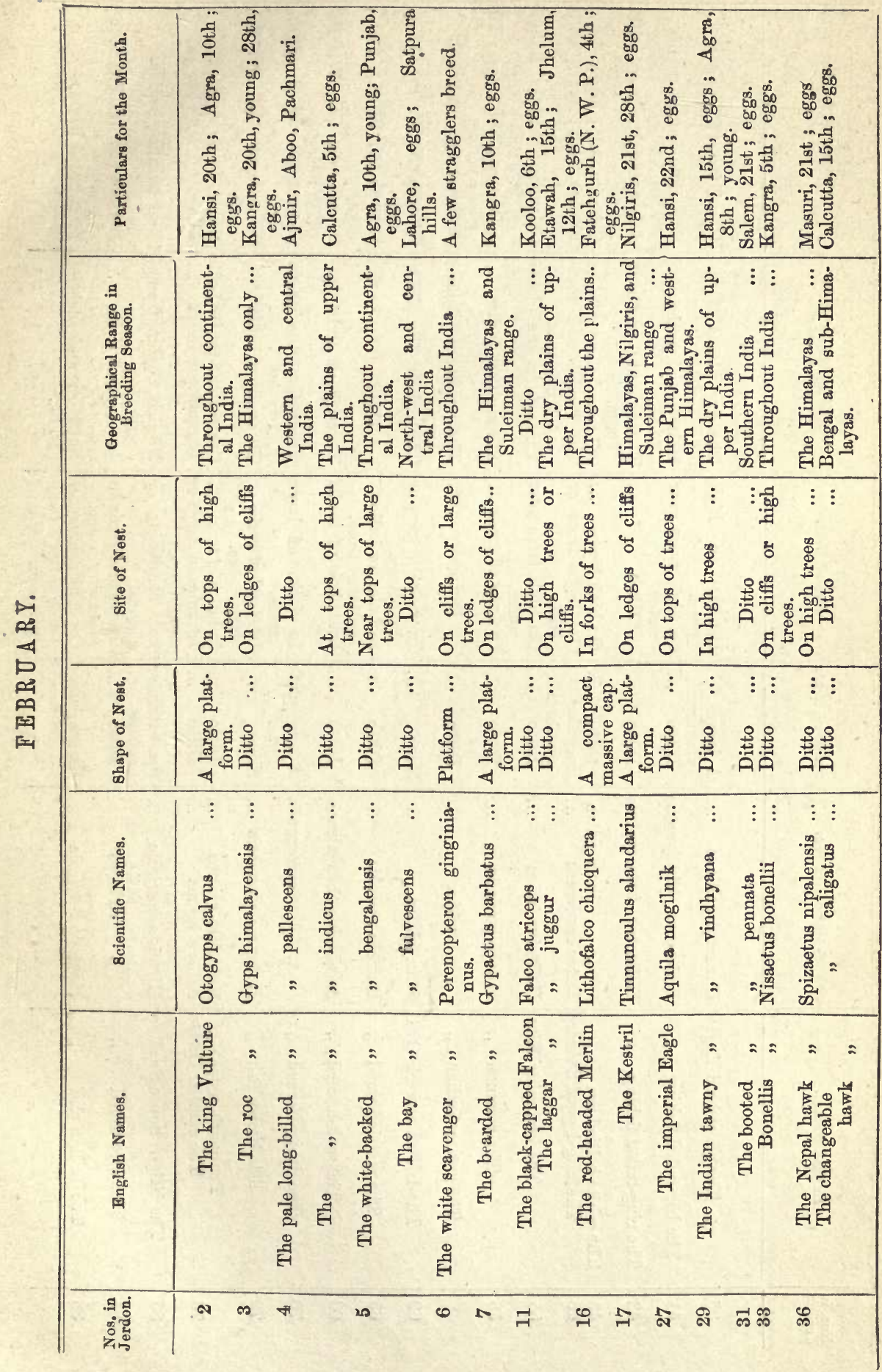




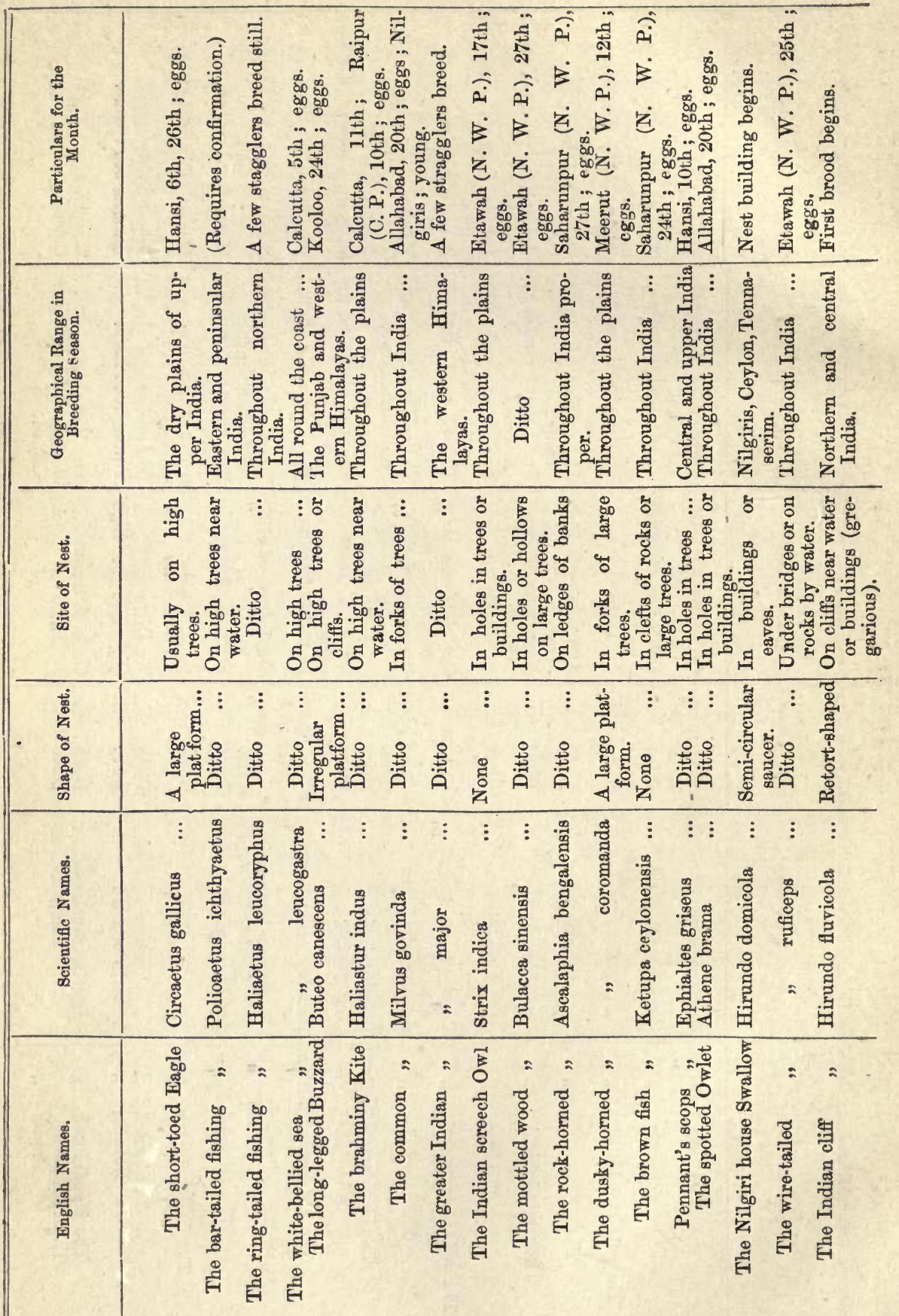




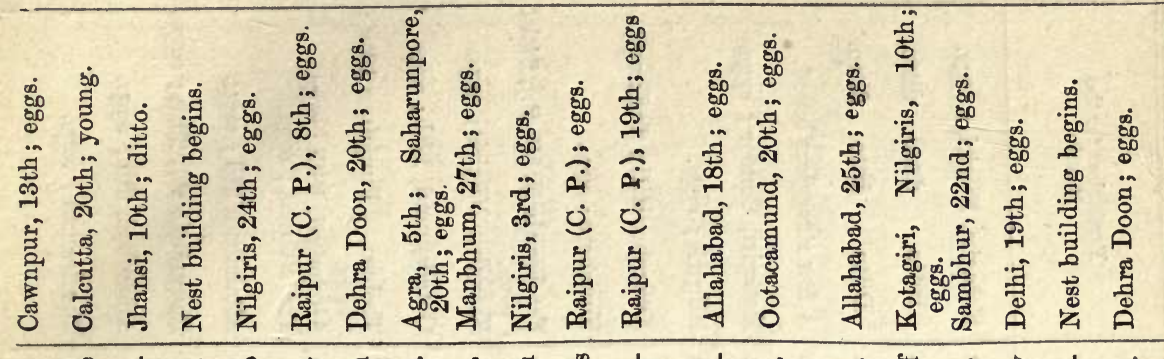

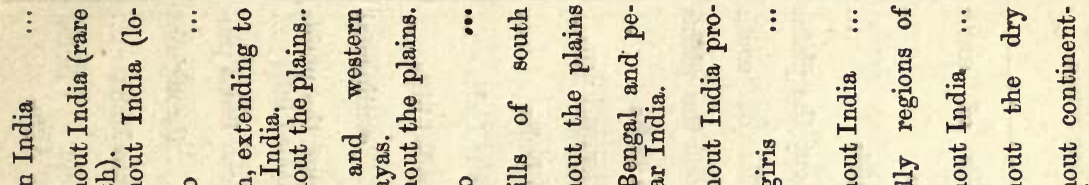

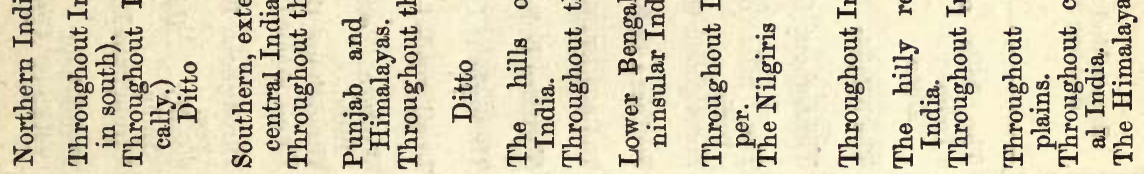

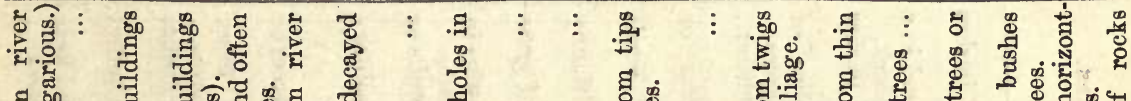
a

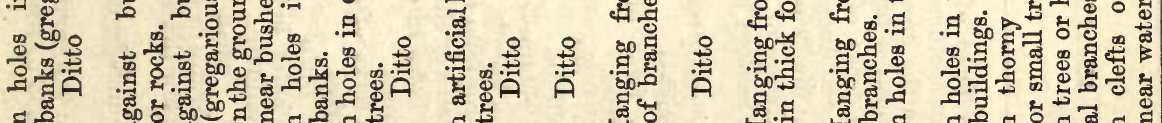
品

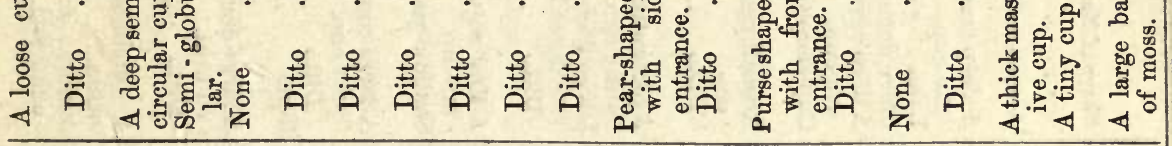

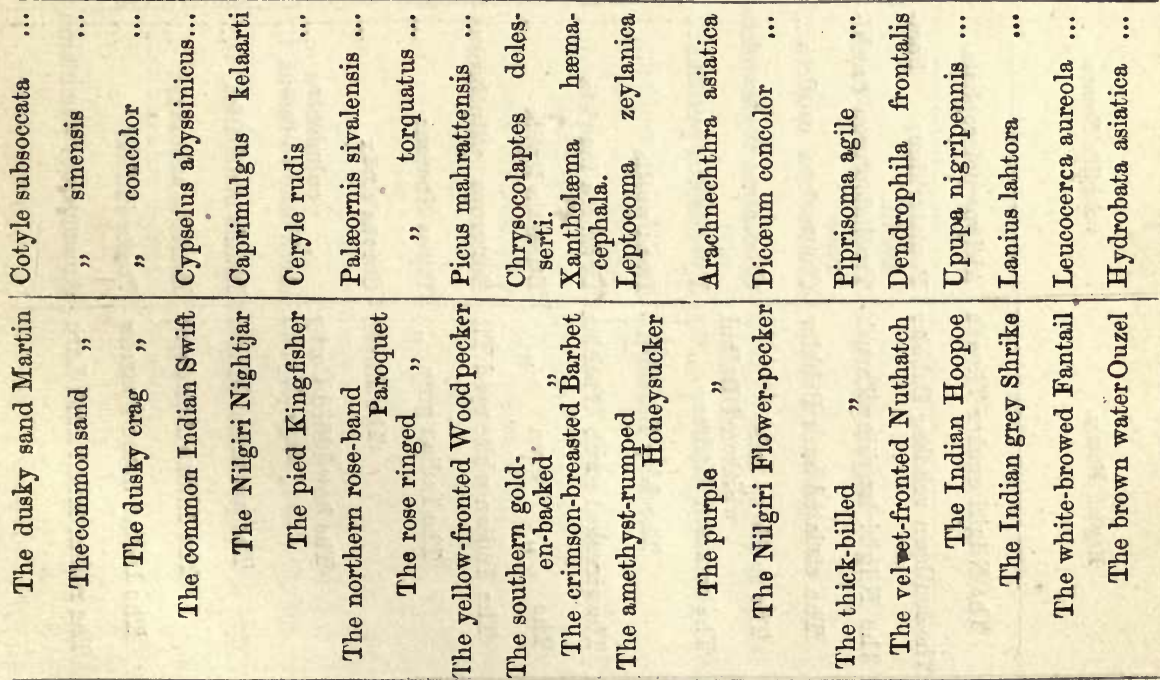

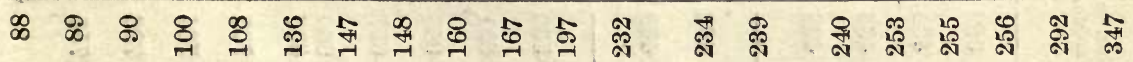


FEBRUARY.

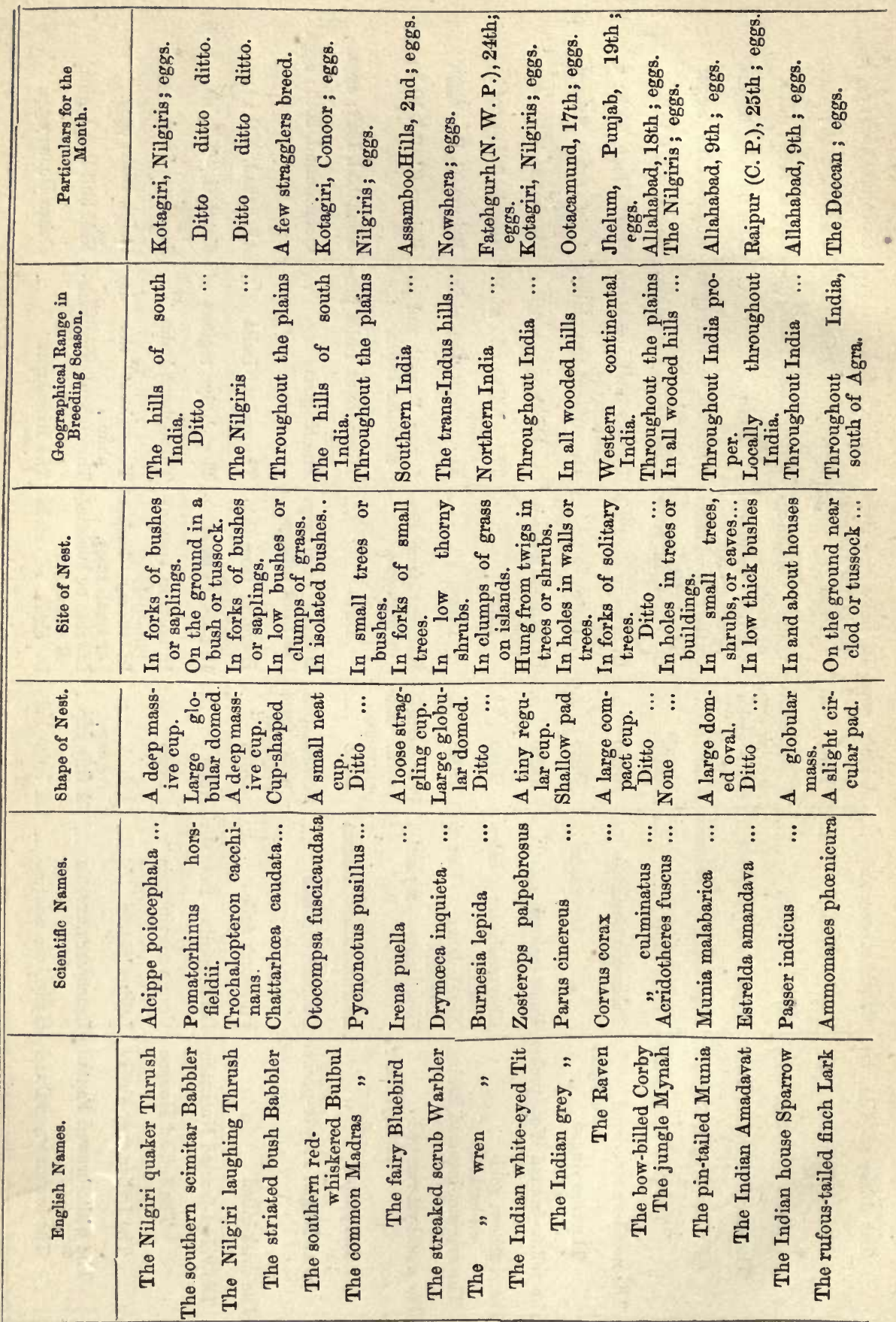

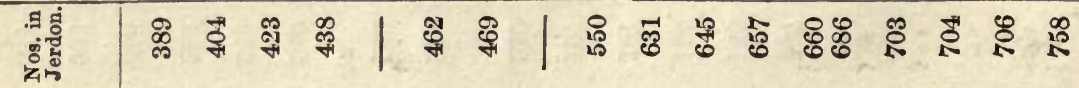




\section{A R C H.}

THE birds of prey are still in full season, and though many of the larger kinds have ceased to lay their places are filled by others, especially among the owls. Most of the bee eaters, kingfishers, parrots, woodpeckers, barbets, nuthatches, larks, plovers, and terns are either laying or building, and several species of swifts, goatsuckers, shrikes, flycatchers, thrushes, babblers, bulbuls, chats, warblers, titlarks, jays, mynahs, and game birds are beginning to lay.

In the Himalayas, the king vulture is still laying, also the bearded vulture (Lammergeyer), the black-capped falcon, and Bonelli's eagle. The crested serpent eagle, the long-legged buzzard and the greater Indian kite, and several of the owls are laying. The slatyheaded paroquet and the scaly-bellied green woodpecker have eggs. The white-tailed and velvet-fronted uuthatches, the boopoe, the bronzed drongo, the ashy swallow shrike, the verditer flycatcher, the Nepal quaker thrush, the white-browed warbler, the white-eyed tit, the red-capped, crested black, and mountain tits, the nutcracker, magpie and jay, the large hill mynah, the tree sparrow, and the white-crested king pheasant all begin laying; and the goshawk, Himalayan fishing eagle, collared pigmy owlet, common swallow, crag and Kashmir martins, Hodgson's trogon, roseband paroquet, woodpeckers, piculets, flower-peckers, tree-creepers, raquet-tailed drongos, chestnut-bellied chat thrush, white-collared ouzels, missel thrush, red-headed wren babbler, rufous-necked and rusty-cheeked scimitar babblers, black gorgetted laughing thrush, iron grey bushchat, blue-headed redstart, black-eared and grey-headed warblers, western spotted forktails, yellowcheeked tits, blue magpies, green jays, and spotted-winged stares are all pairing and building.

In the PunjaB, the vultures, hawks, falcons, and true eagles are still laying, also the short-toed eagle. The buzzards and several owls commence laying. The dusky crag martin, the pied kingfisher, the grey shrike, the babblers, the streaked scrub warbler, the streaked wren warbler, the raven, the larks, doves, the common sandgrouse, the common quail, the big bustard, most of the plovers, the common heron, the king curlew, most of the terns, and the scissor bill have eggs during the month; and the painted sandgrouse, the seesee partridge, the lesser button quail, and the gull-billed terns are pairing and making their nests.

In the North-West Provinces, the white scavenger vulture 


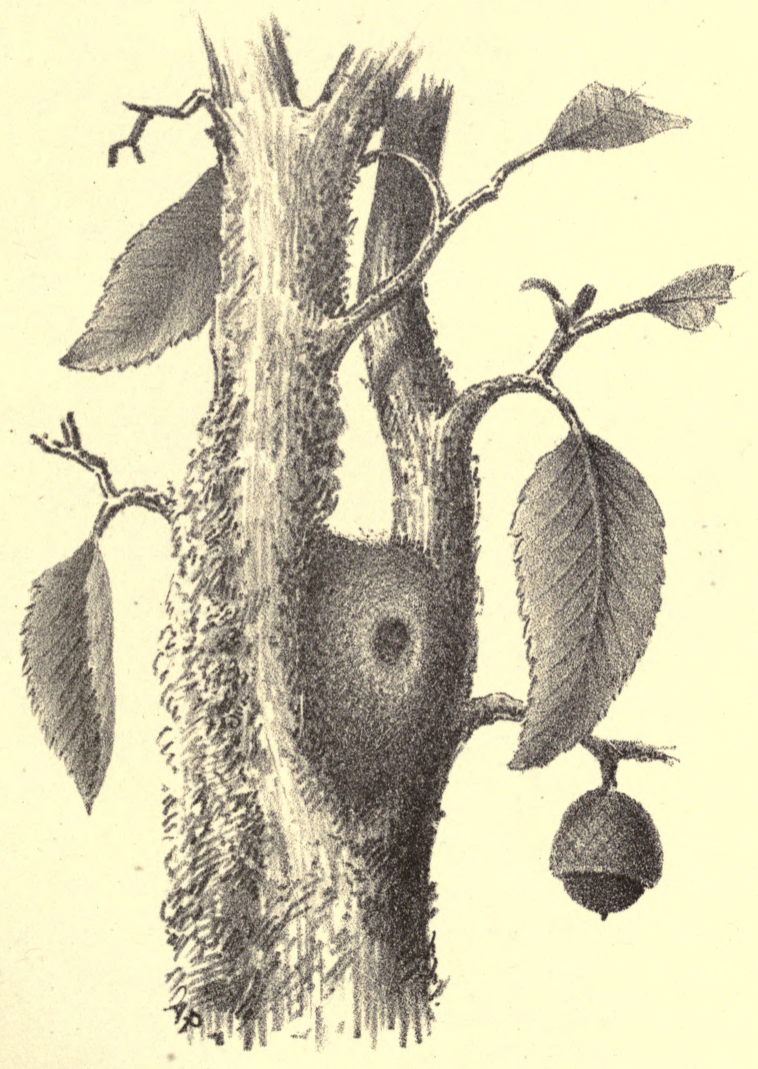

MARSHALL OEL.

NEST OF THE RED-HEADED TIT.

(Egithatiscus erythrocephatus.) 
and 
and a few of the king vultures are the only vultures with eggs at this season. The laggar falcon, the red-headed merlins, the changeable hawk eagles, buzzards, kites, and most of the owls, are still laying. All the swallows and martins, the blue-tailed bee eater, the roller, the parrots, woodpeckers and barbets, the flower-peckers, honey suckers, nuthatches, robins, chats, titlarks, carrion crows, larks of all kinds, green pigeons, emerald doves, grey partridges, bush quail, common quail, most of the plovers, the river terns, and the scissor bills have all got eggs. The following birds not included in the list that follows begin building during the month, and should be watched:-The shikra hawk, the jungle owlet, the blue-ruffed bee eater, the northern grey hornbill, the large grey cuckoo shrike, Sykes, warbler, and the common cormorant.

In Bengal, the palm roof swift in the Garn hills lays throughout the month. The large Bengal nightjar, the white-breasted kingfisher, the red-breasted paroquet, the Indian loriquet, the yellow-fronted woodpecker, Franklin's green barbet, the koel, honey suckers, flowerpeckers, the common wood shrike, the common babbler, the redwhiskered and white-winged green bulbul, the black-headed oriole, the black crow, Sykes' turtle dove, the red jungle fowl, the kyah partridge, plovers, river terns, and scissor bills all have eggs. The species that commence nest-building during the month are Jerdon's green bulbul, the shama robin, and the white-backed munia.

In Central India, the cliff swallows, crag martins, blue-tailed bee eater, little kingfisher, rock chat, rufous-tailed finch lark, painted spur fowl, and plovers are the characteristic species that lay during the month, but many of the species that breed at this time in northern, and particularly southern India, breed also now in central India. The species that begin building in this month are the jungle nightjar and the purple heron.

In Southern India, the kestril is still laying, and probably some of the owls. The jungle nightjar, chestnut-headed bee eater, little kingfisher, lesser green woodpecker, the green barbet, the sirkeer, flowerpecker, some shrikes, flycatchers, thrushes, blackbirds, quaker thrushes, babblers, laughing thrushes, bulbuls, robins, chats, the ashy wren warbler, titlark, tits, long-tailed treepie, mynahs, larks, grey jungle fowl, red spur fowl, and red-winged bush quail are the kinds that breed throughout the month. The white-bellied short wing in the Pulneys, and the green pigeons and Nilgiri wood pigeons commence building their nests. 


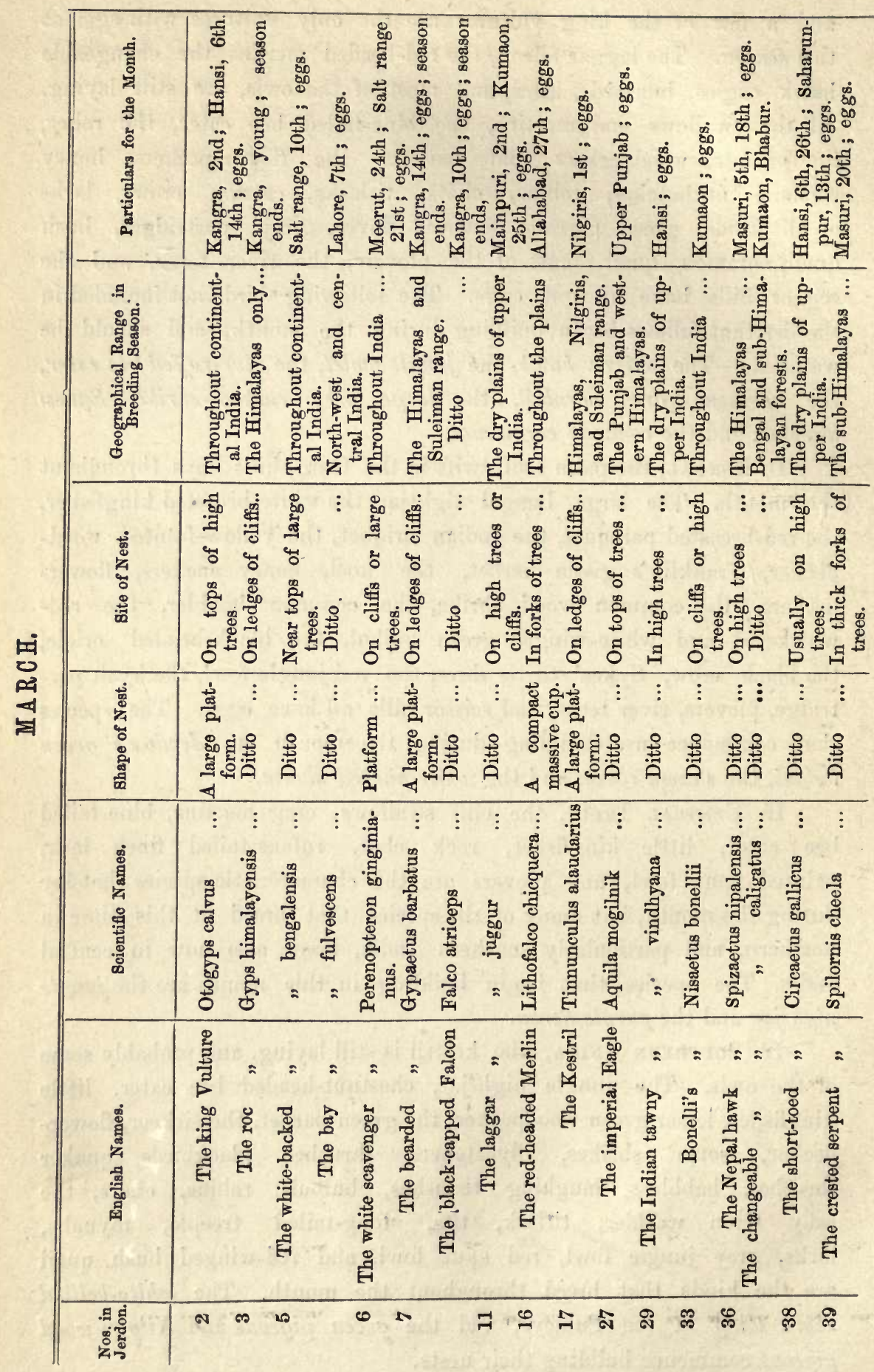




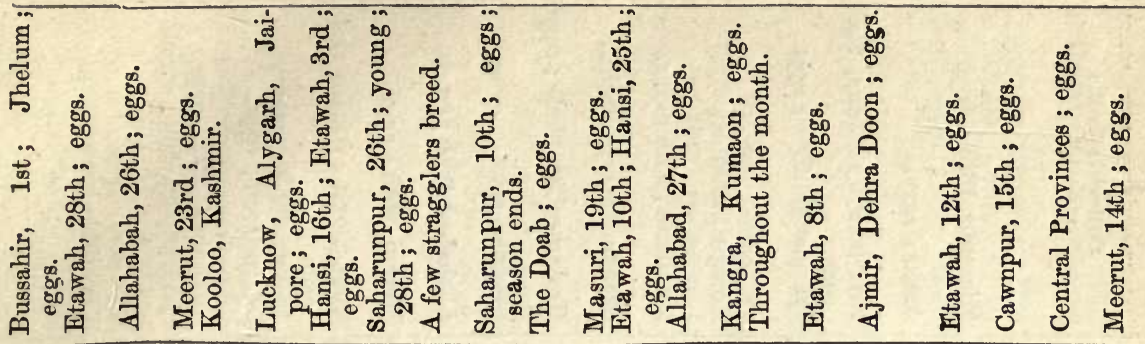

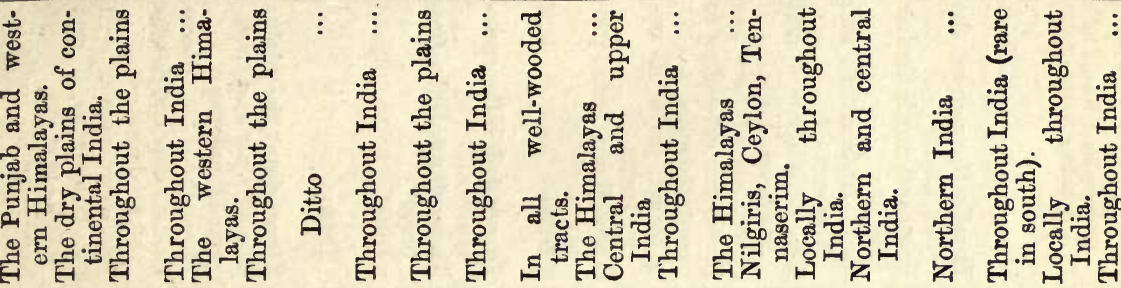

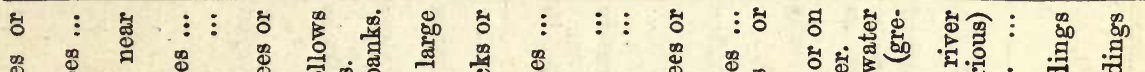

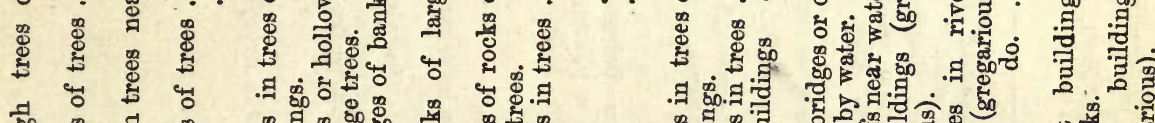

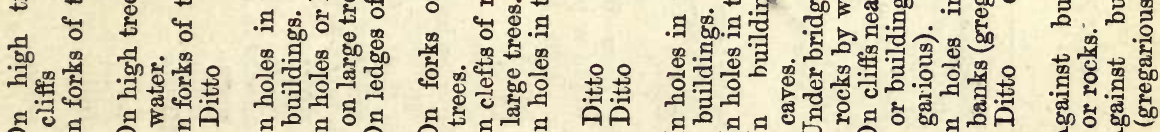

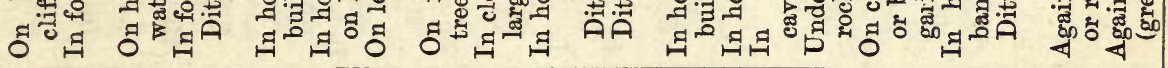
蚝

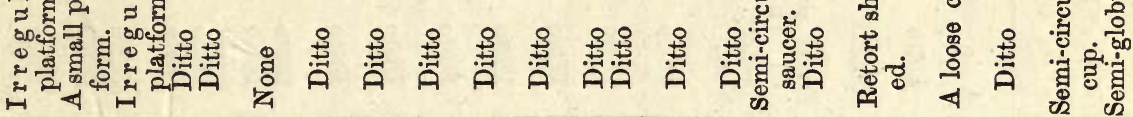

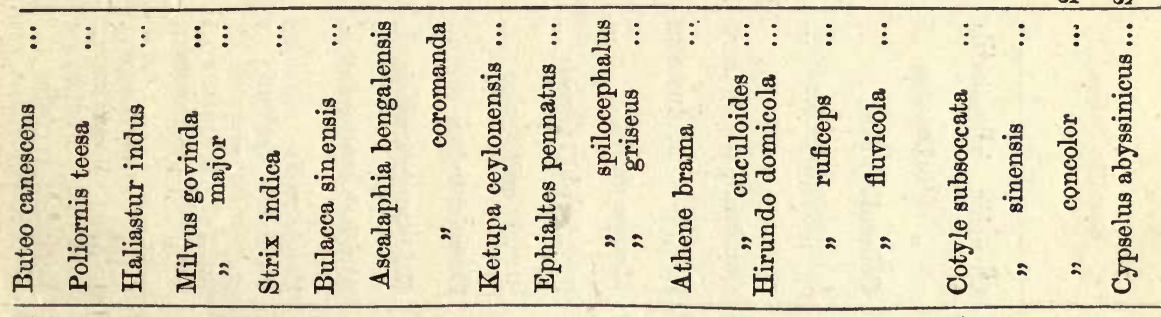

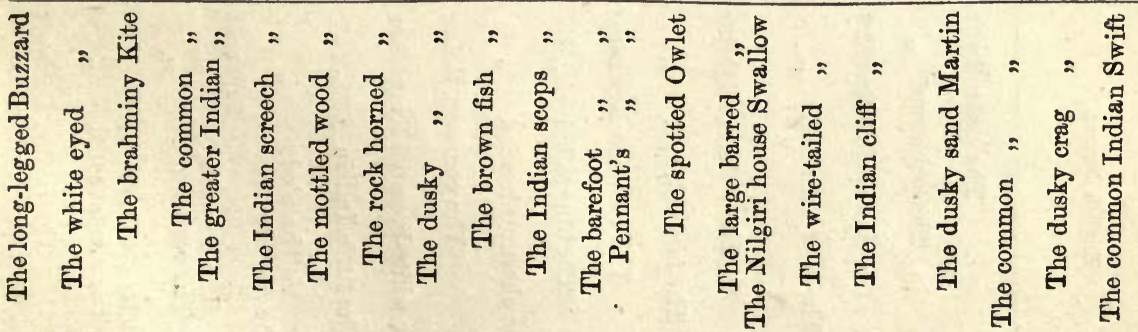

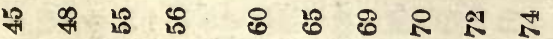

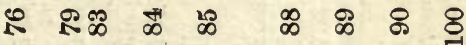




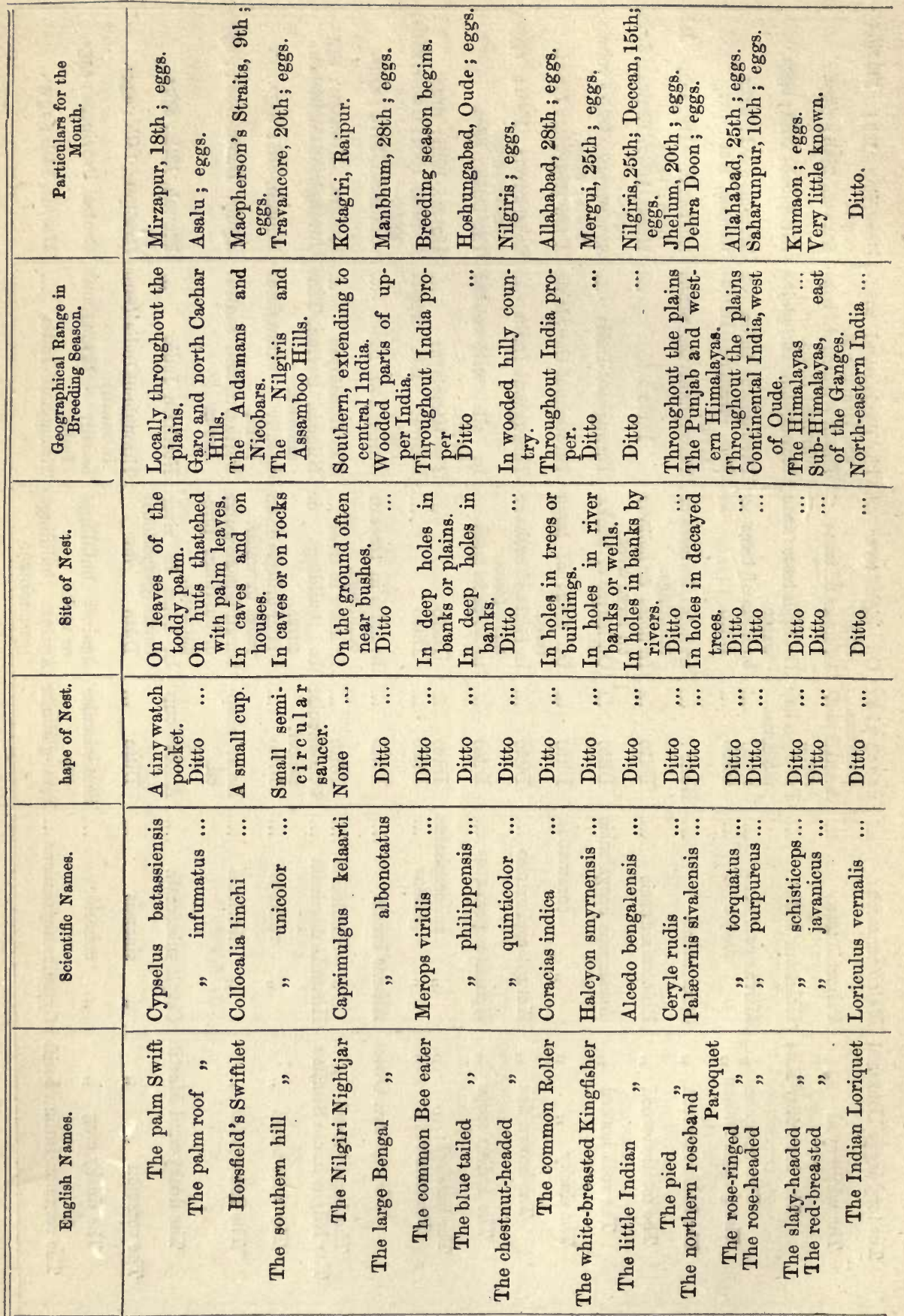

量高 总 


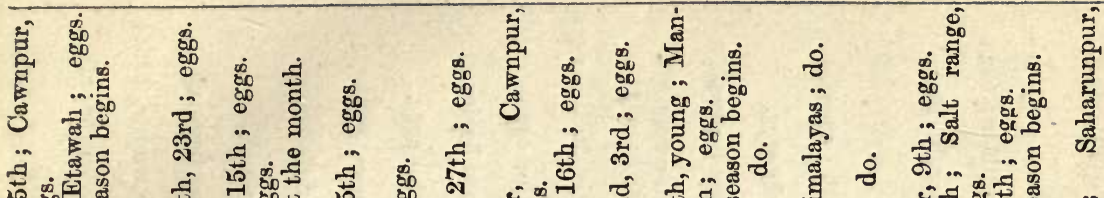

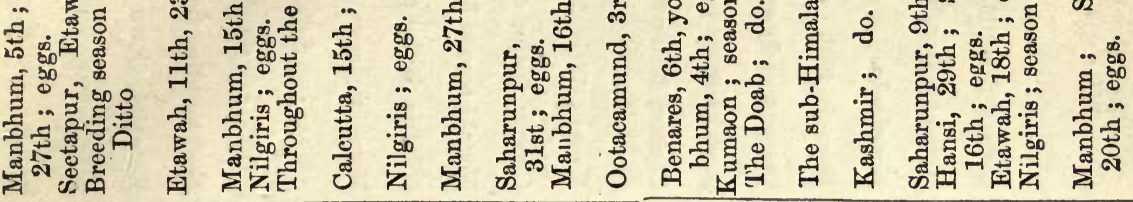

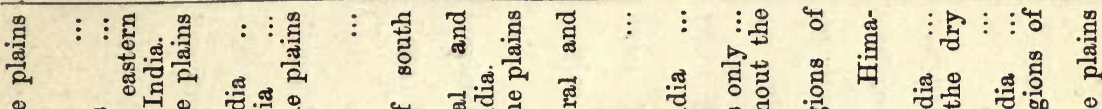

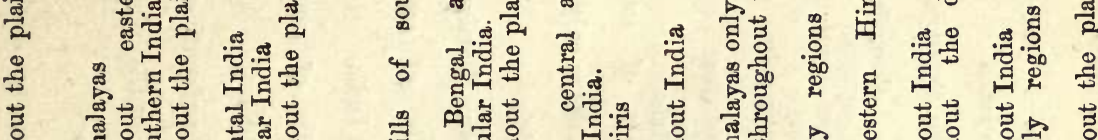

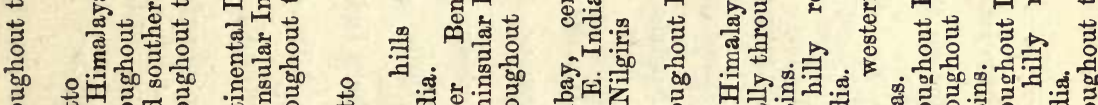
윱

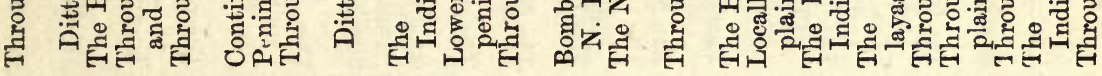

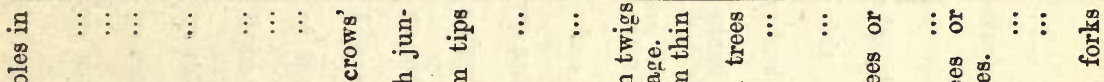

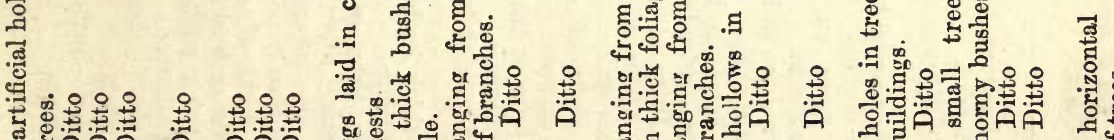
要调

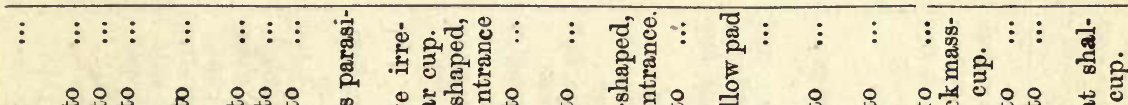

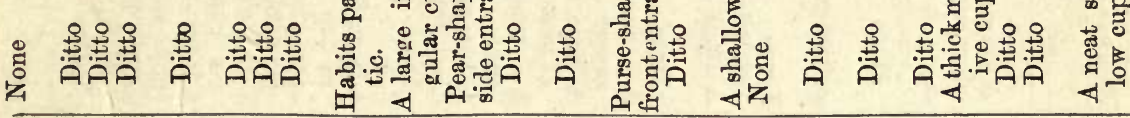

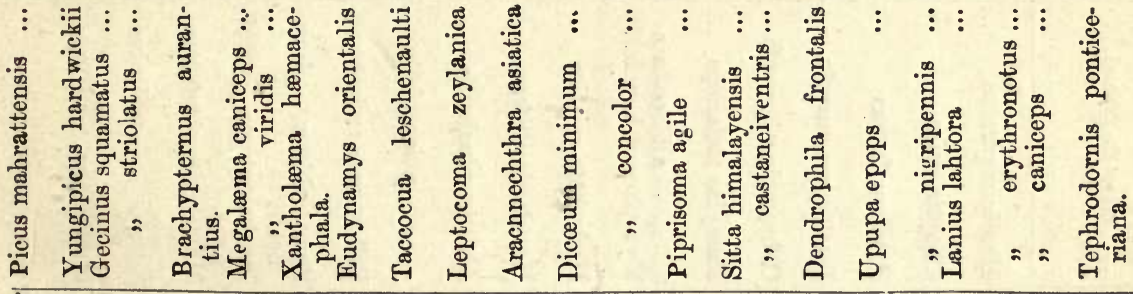

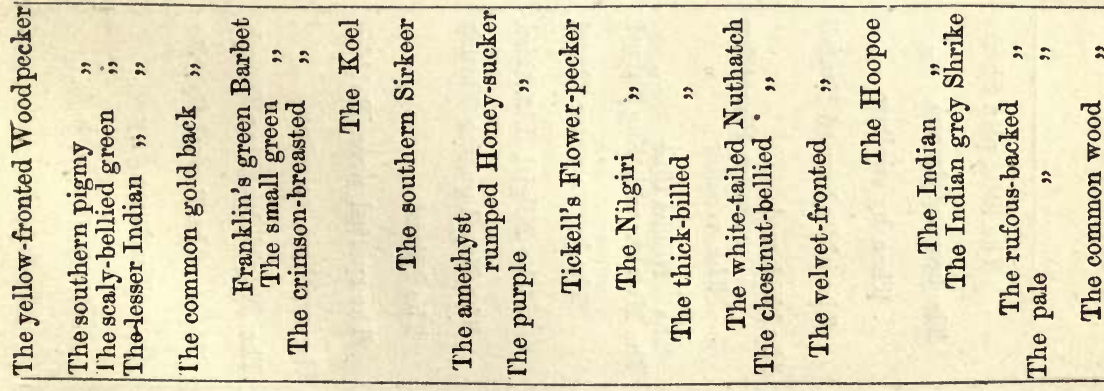

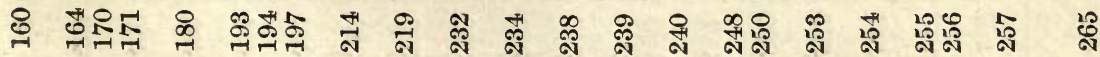




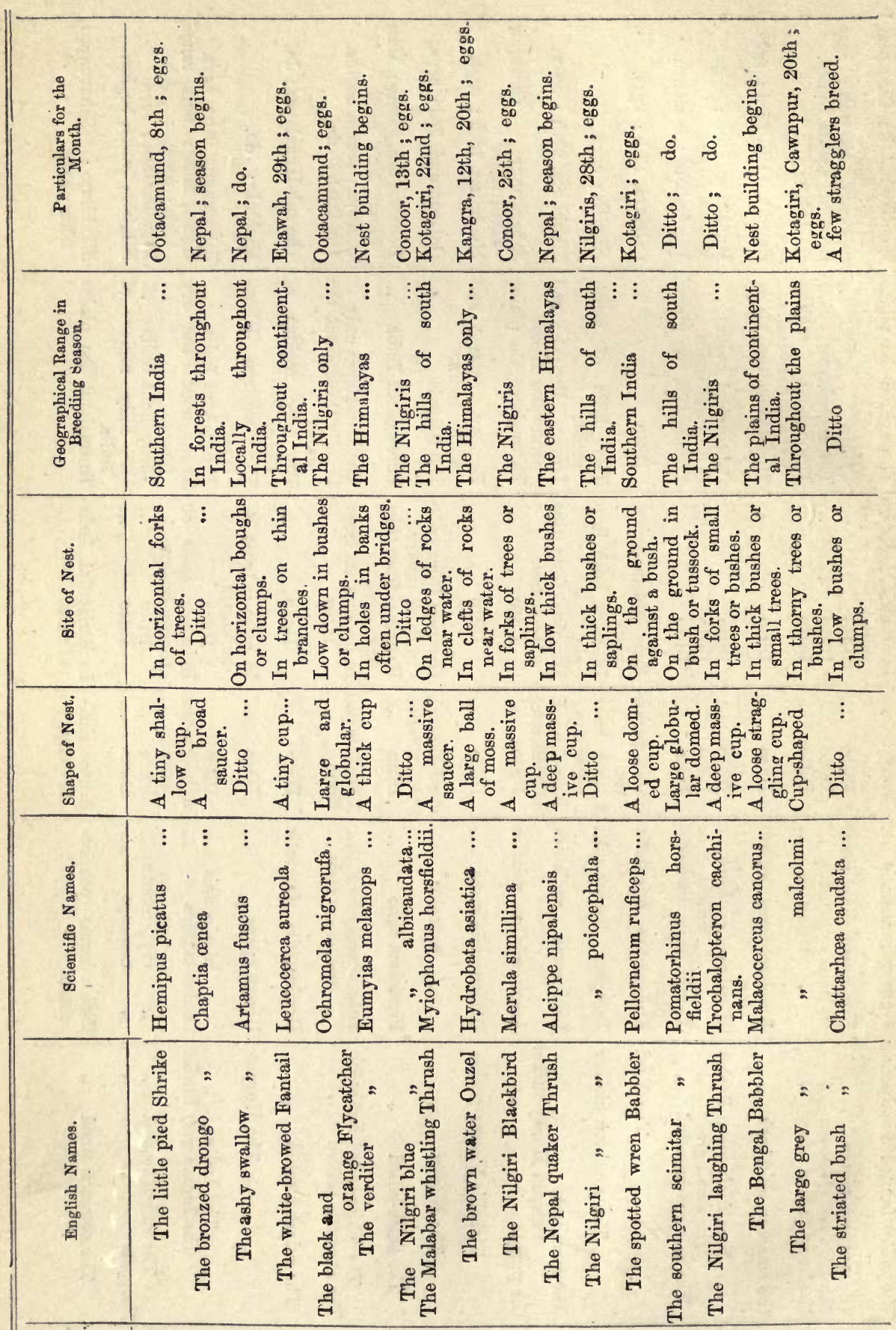

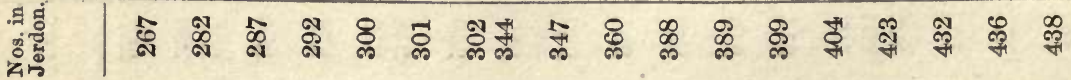




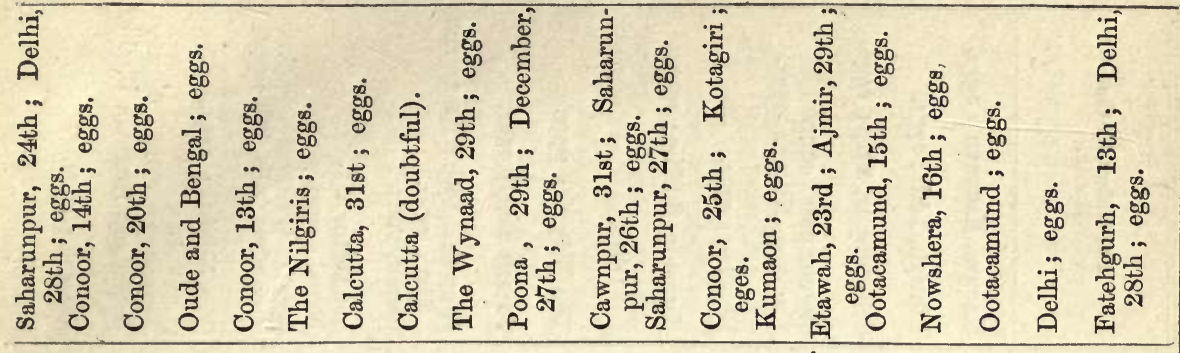
惡

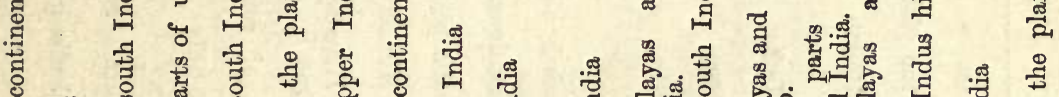

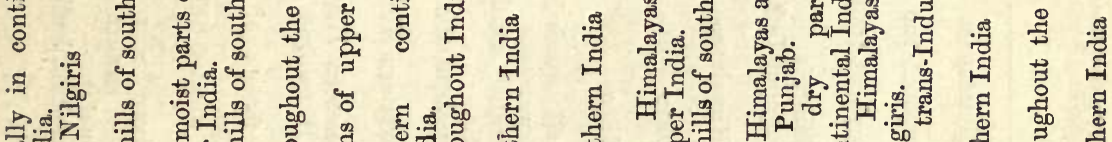

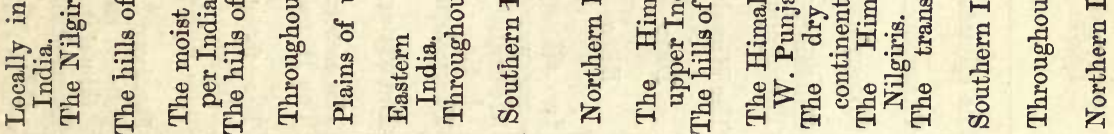

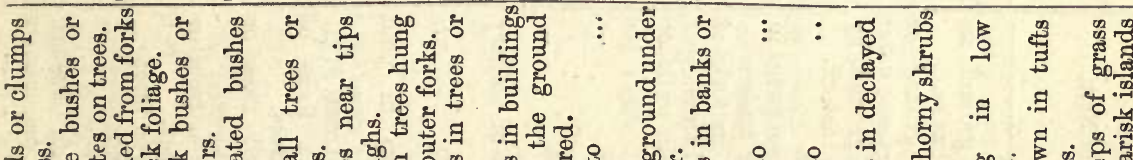

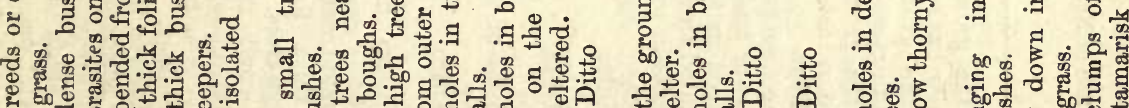

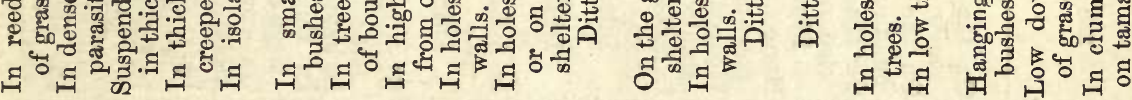

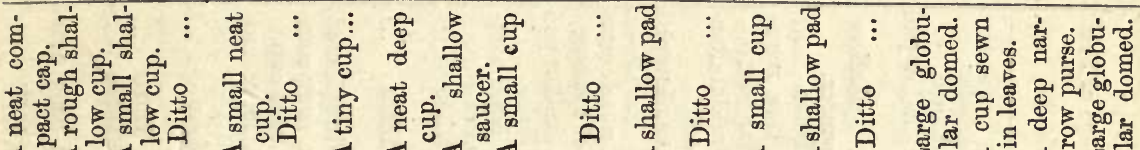

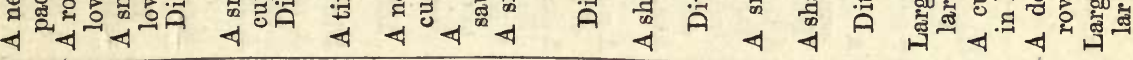

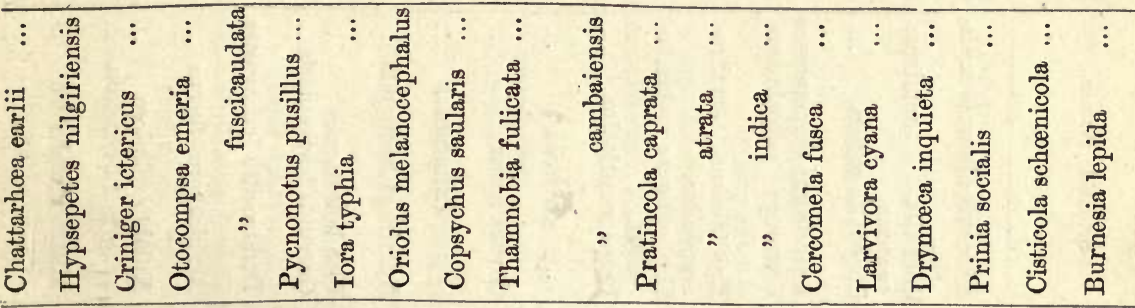

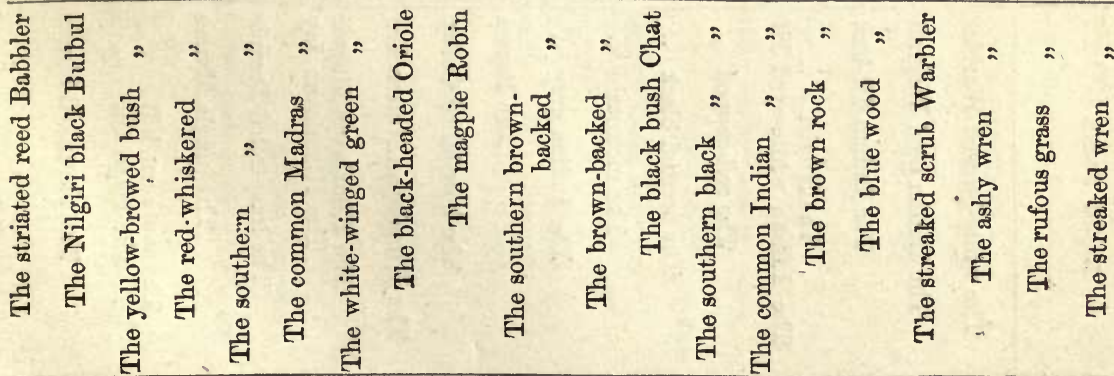
है

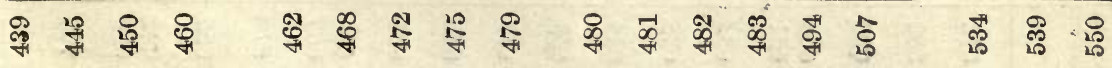




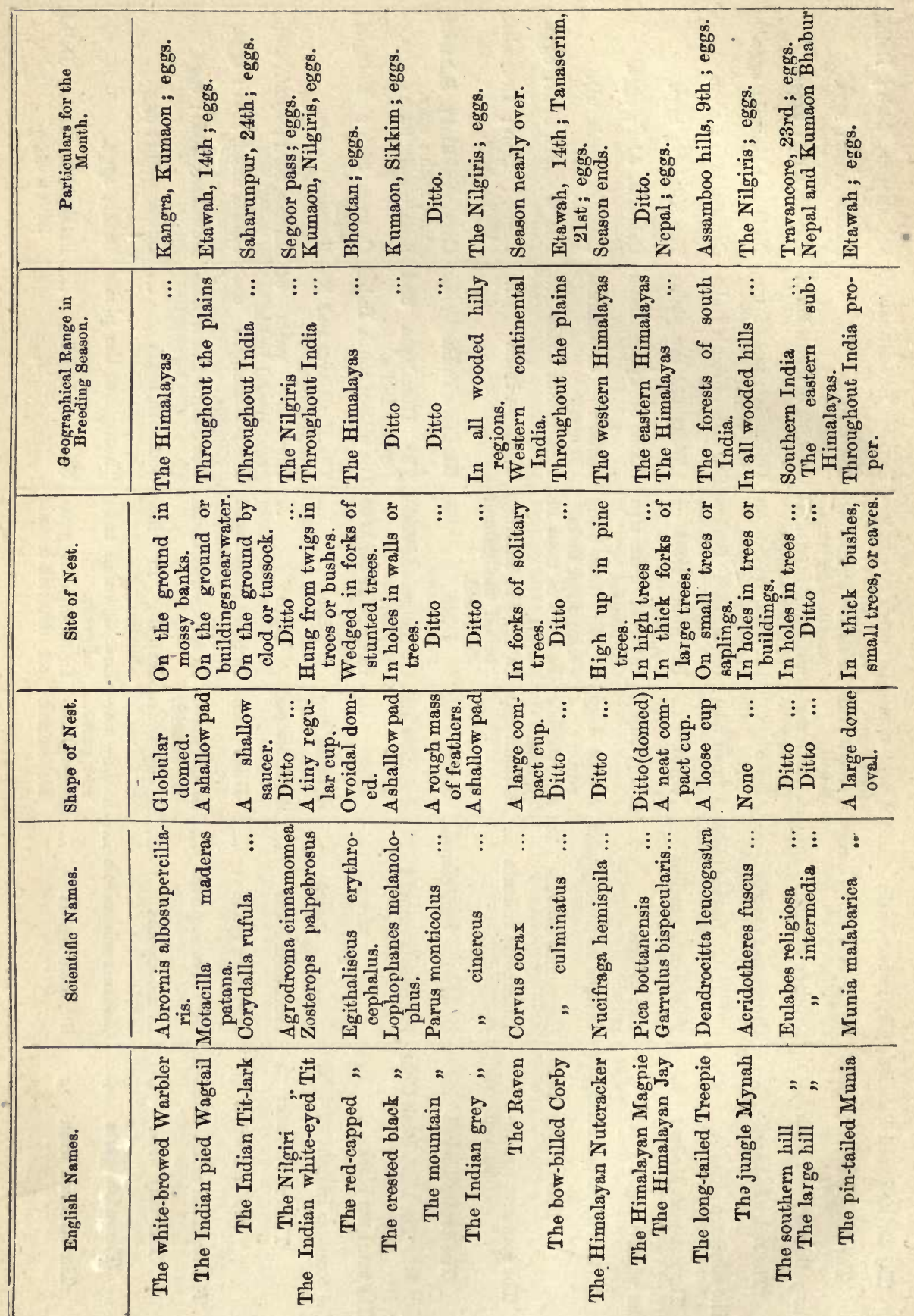

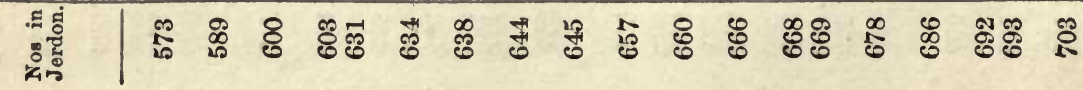




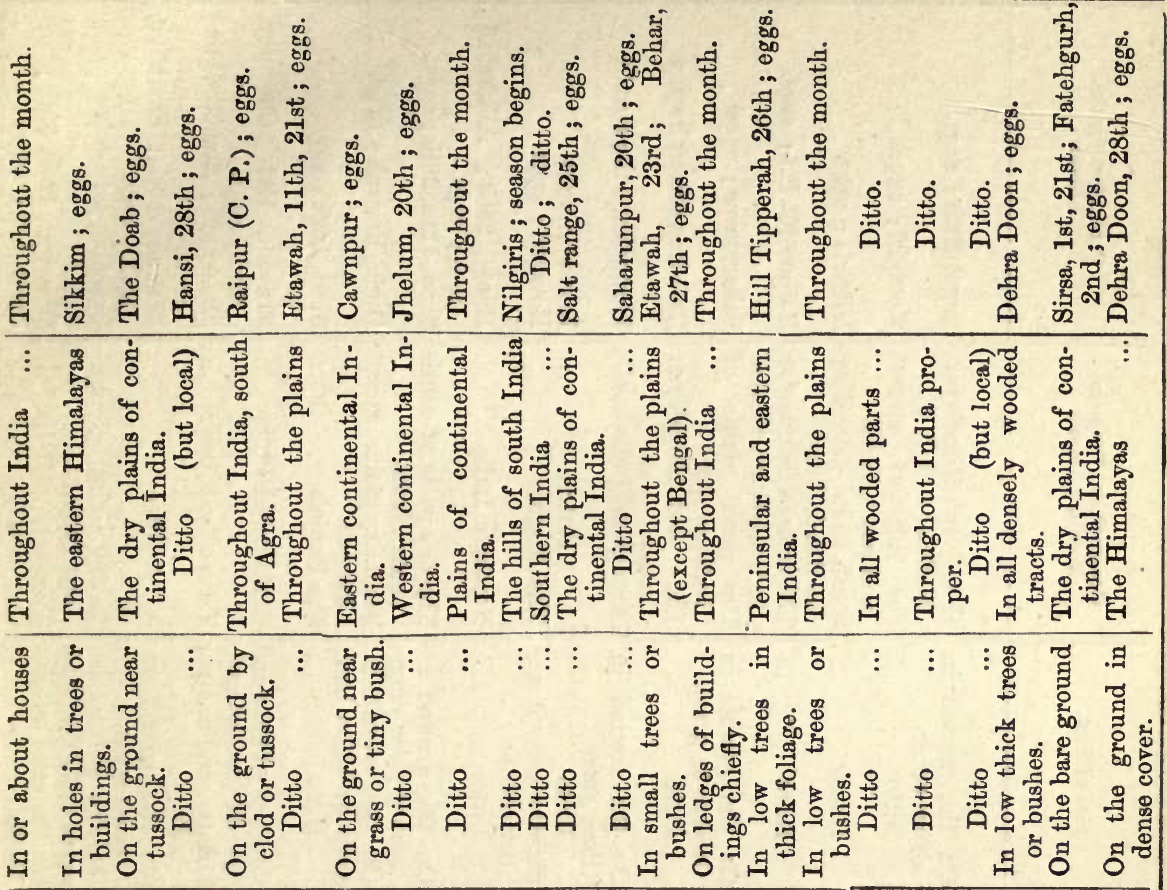

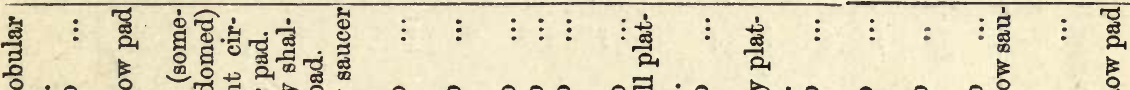
४萌

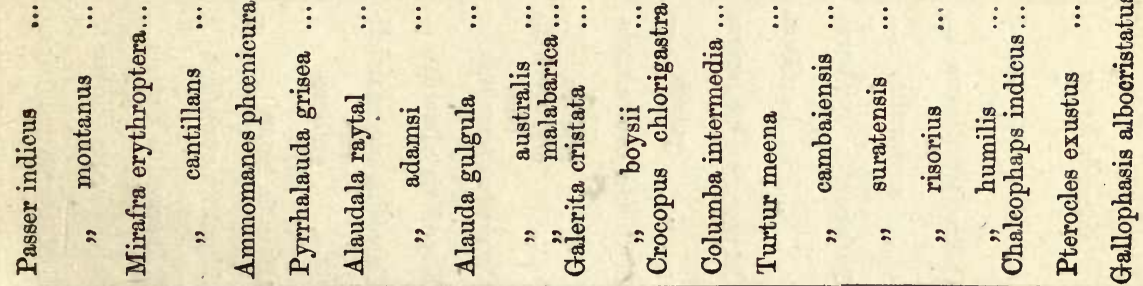

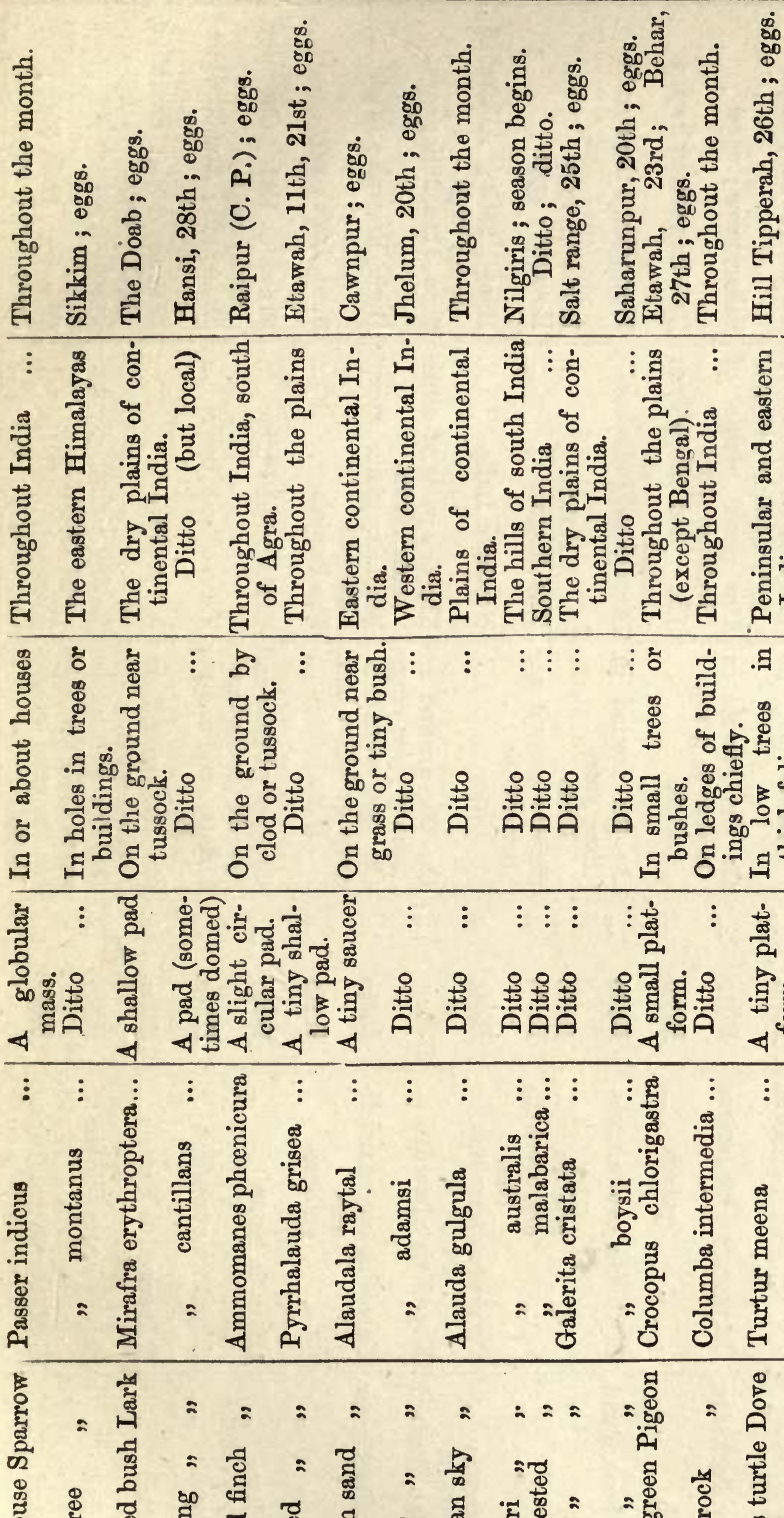

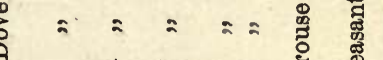

‡.

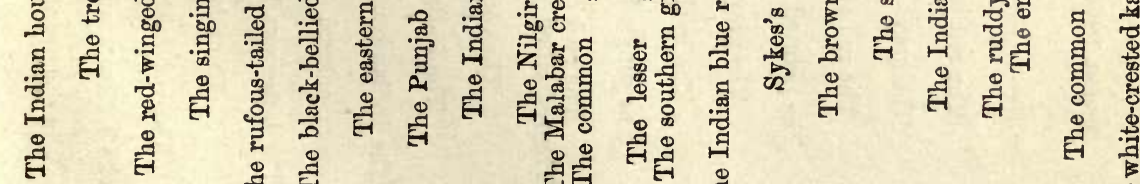

है है

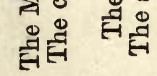

है

स्थ

氙

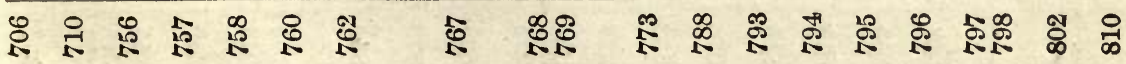




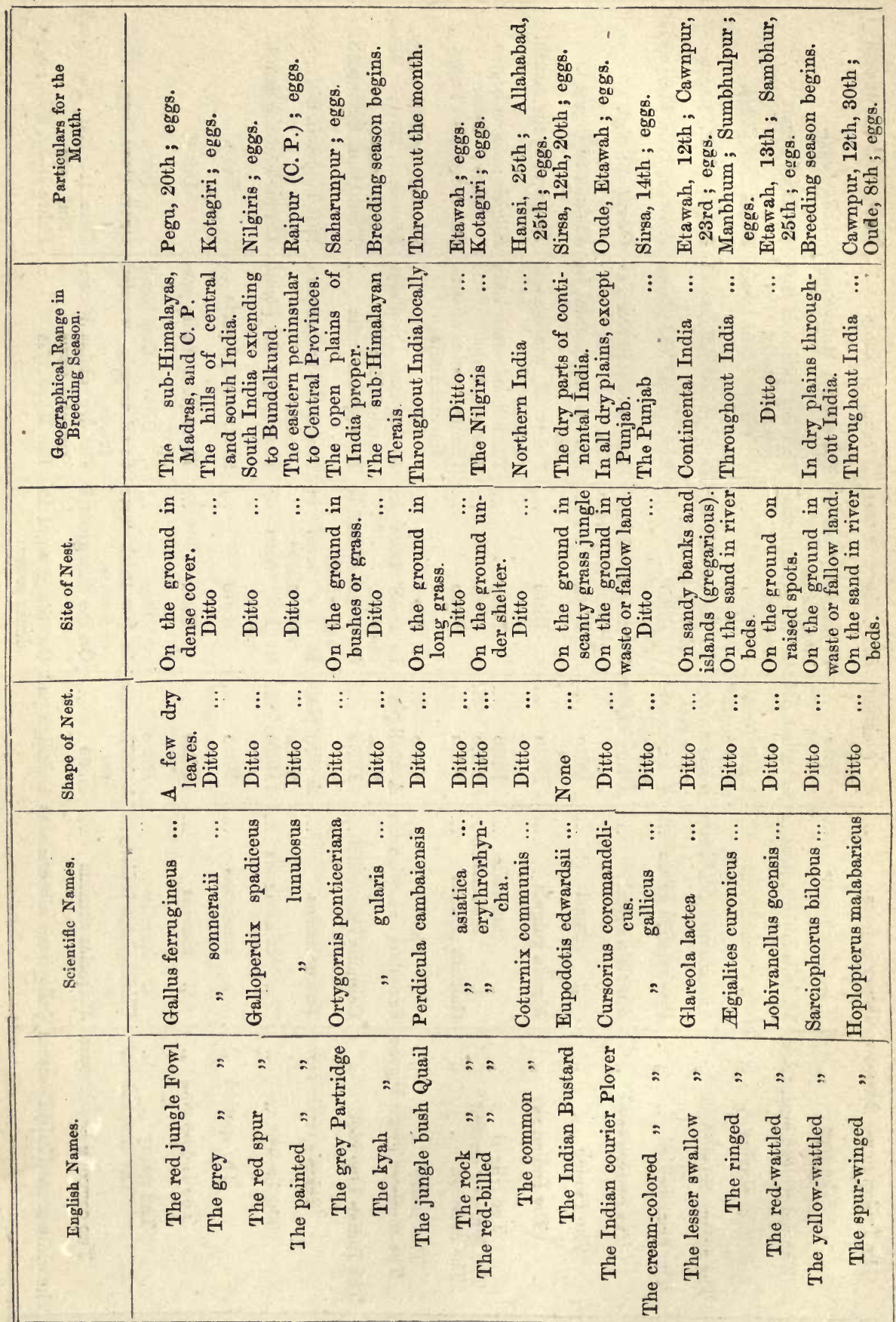

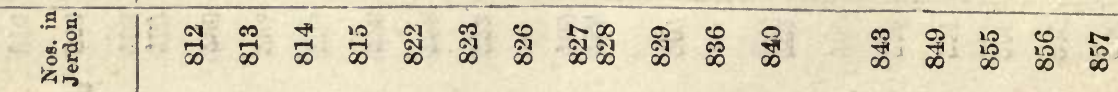




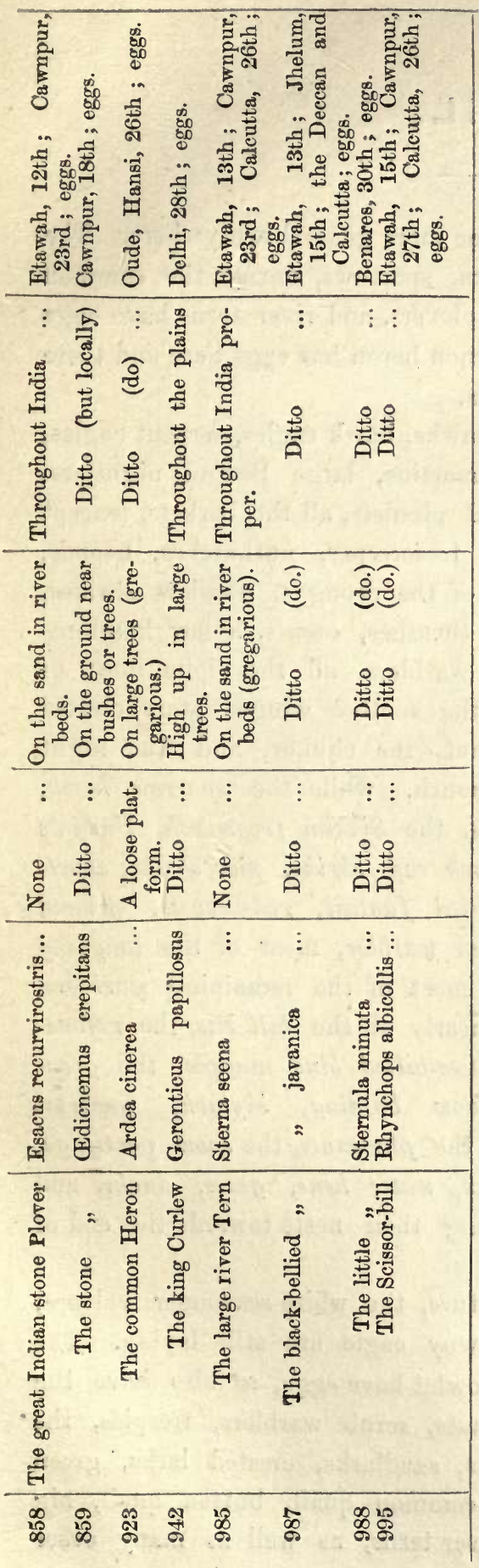




\section{APRIL.}

BRHEDING has by this time become more general everywhere. The kites and buzzards, the shrikes, tit larks, sparrows, doves, the common sandgrouse, jungle fowl, spur fowl, plovers, and river terns have eggs in all parts of the country. The common heron has eggs here and there in northern, western, and central India.

In the Himalayas, most of the hawks, hawk eagles, serpent eagles, the barefoot scops owl, the owlets, martins, large Bengal nightjars, trogons, most of the woodpeckers and piculets, all the barbets, (except the Marshall's barbet,) honey-suckers, treecreeper, nuthatches, hoopoe, cuckoo shrike, large minivet, some of the drongos, swallow shrikes, most of the flycatchers, shortwings, thrushes, ouzels, a few laughing thrushes, bushchats, most of the tree warblers, all the pipits, most of the true tits, crows, jackdaws, jays, the spotted winged stare, crested bunting, white-crested kalij pheasant, the chukor, and the night heron have eggs throughout the month, while the sparrow hawk, wood owl, the rest of the scops owls, the Sikkim frogmouth, Unwin's nightjar, the European bee eater, black cap shrike, pied shrike, shortbilled minivet, drongos, yellow-bellied fantail, red-breasts, ground thrushes, blackbirds, black-headed wren warbler, most of the laughing thrushes, a few bulbuls, the redstarts, most of the remaining warblers, the forklails, waglails and pipits, nearly all the hill tits, the rufousbreasted accentor, the corby, the yellow-billed llue magpie, the greyheaded mynah, the sparrows, meadow bunting, skylark, imperial pigeons, turtle doves, all the rest of the pheasants, the snow partridge, bustard quail, woodcock, sandpipers, water hens, geese, ducks, and grebe are pairing and commence building their nests towards the end of the month.

In the PunJaB, the king vulture, the white scavenger vulture, the red-headed merlin, and Indian tawny eagle are still laying. The screech owl and scops owl, and little owlet have eggs, so also have the striated reed babblers, the rock chats, scrub warblers, treepies, the bright starlings, singing bush larks, sandlarks, crested larks, green pigeons, the seesee partridges, the common quail, button quail, big bustard, plovers, king curlew, and river terns, as well as many other 

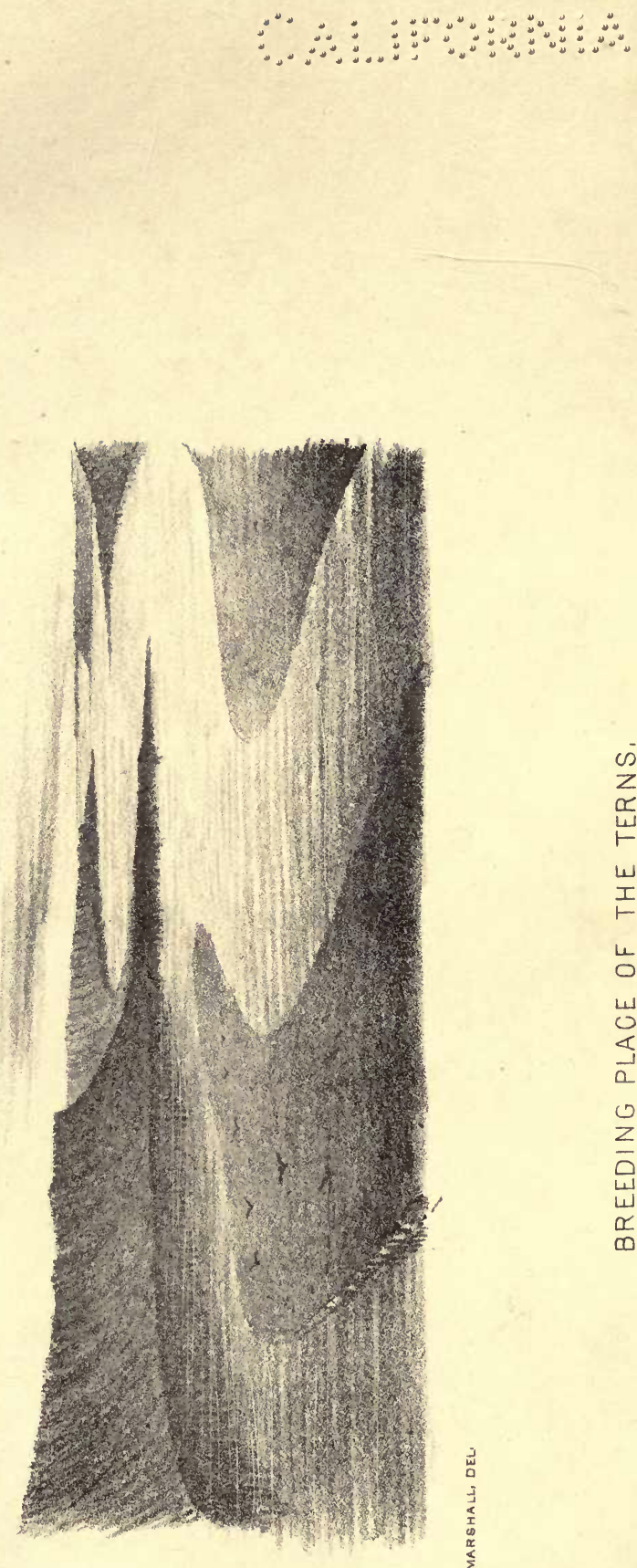

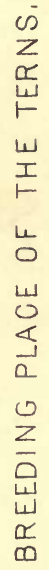


birds which have been found breeding in the North-West Provinces and central India. The Egyptian bee eaters and desert finch larks commence nest building towards the end of the month.

In the North-West Provinces, the shikra, the short-toed serpent eagle, buzzards, kites, and most of the owls have still got eggs. The wire-tailed and mosque swallows, the sand martins, common swifts, blue-tailed bee eaters, the kingfishers, hornbill, green barbets, cuckoo shrikes, fantails, grey babblers, bulbuls, ioras, robins, chats, Sykes's warbler, pied wagtails, treepies, bush larks, sand larks, finch larks, rock pigeons, jungle fowl, plovers, and the common cormorant are laying during this month: while the common drongo and the brahminy mynah are beginning to pair and build, also a few pairs of the concal and sirkeer build in the eastern parts.

In Bengal, the spotted eagle is laying. The large Bengal nightjar, the stork-billed kingfisher, the koel, the common wood shrike, the black-headed wren babbler, the red-whiskered bulbul, the common bulbul, Jerdon's green bulbul, the black-headed oriole, the shama, the tailor bird, the white-backed munia, the orange-breasted green pigeon, Sykes's turtle dove, the red jungle fowl, the kyah partridge, the common quail, and the painted snipe, all have eggs during the month, besides many others common to it and central and western India. The long-legged and spotted eagles, the yellow-breasted and red-capped wren warblers, and the green pigeons are beginning to pair and build.

In Central India, the spotted eagle, buzzards, and kites are laying. The cliff swallow and crested swift have eggs. The jungle and Nilgiri nightjars have begun to lay, and the blue-tailed bee eaters, white-breasted kingfishers, rockchats, finch larks, painted sandgrouse, jungle fowl, spur fowl, plovers, purple herons, as well as the common herons, are sitting. The lesser harrier eagle, Tickell's blue redbreast, the striated marsh babbler, the green amadavat, and the brown rail begin to build towards the end of the month.

In Southern India, the white scavenger vulture is still laying. The house and mosque swallows, dusky crag martins, Nilgiri nightjars, chestnut-headed bee eaters, little kingfishers, green barbets, Tickell's flower-pecker, the velvet-fronted nuthatch, white-spotted fantail, the flycatchers, shortwings, whistling thrushes, blackbirds, quaker thrushes, wren babblers, scimitar babblers, bulbuls, robins, chats, wren warblers, pipits, white-eyed tits, tit larks, treepies, 
jungle mynahs, hill mynahs, wearer birds, munias, larks, green pigeons, wood pigeons, jungle fowl, spur fowl, plovers, and many other kinds have eggs. The lesser kestril in the Nilgiris, the ghat nightjar, the southern blue redbreast, the jungle babbler, and the common crow are pairing and building by the end of the month. 


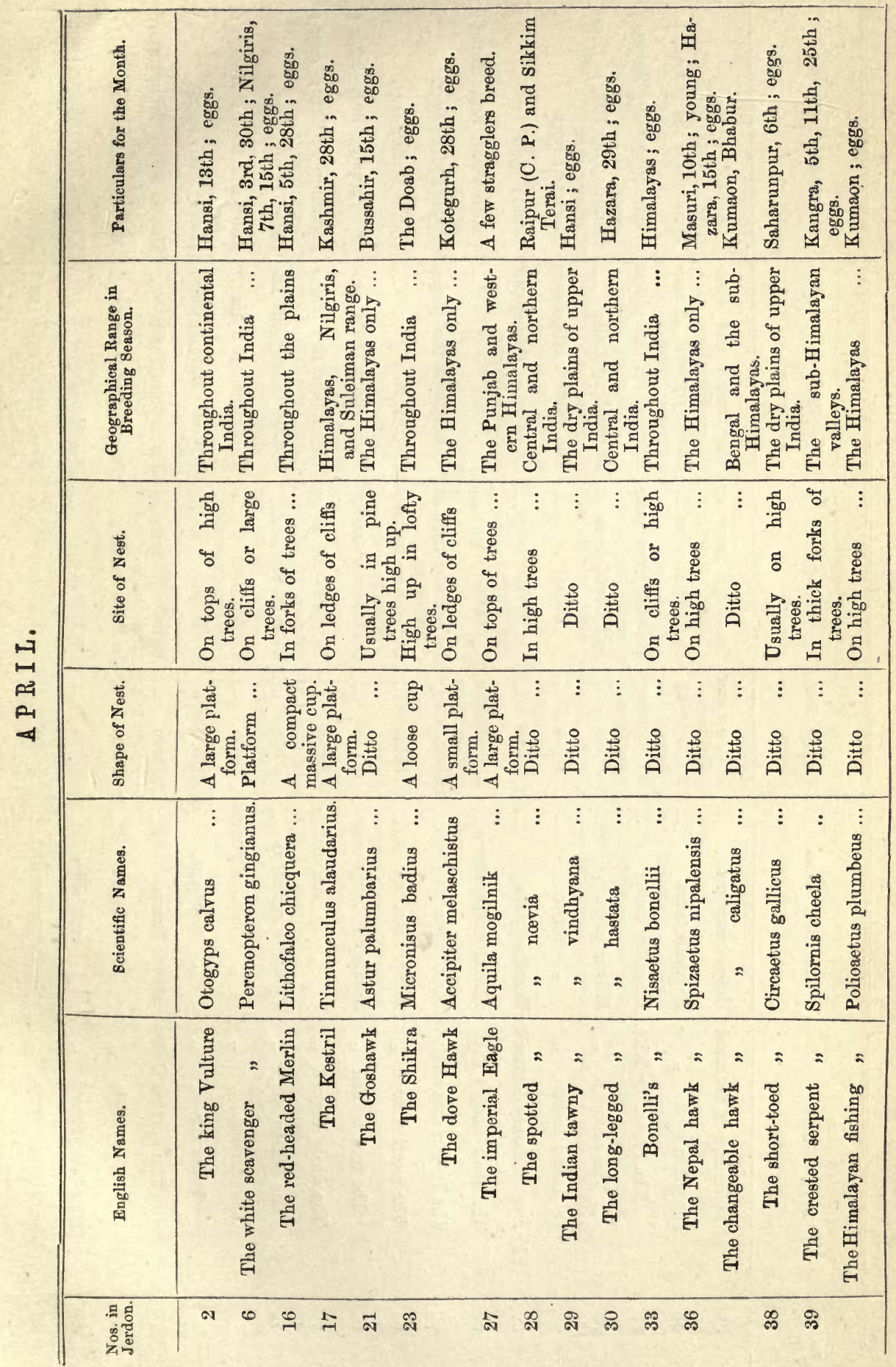




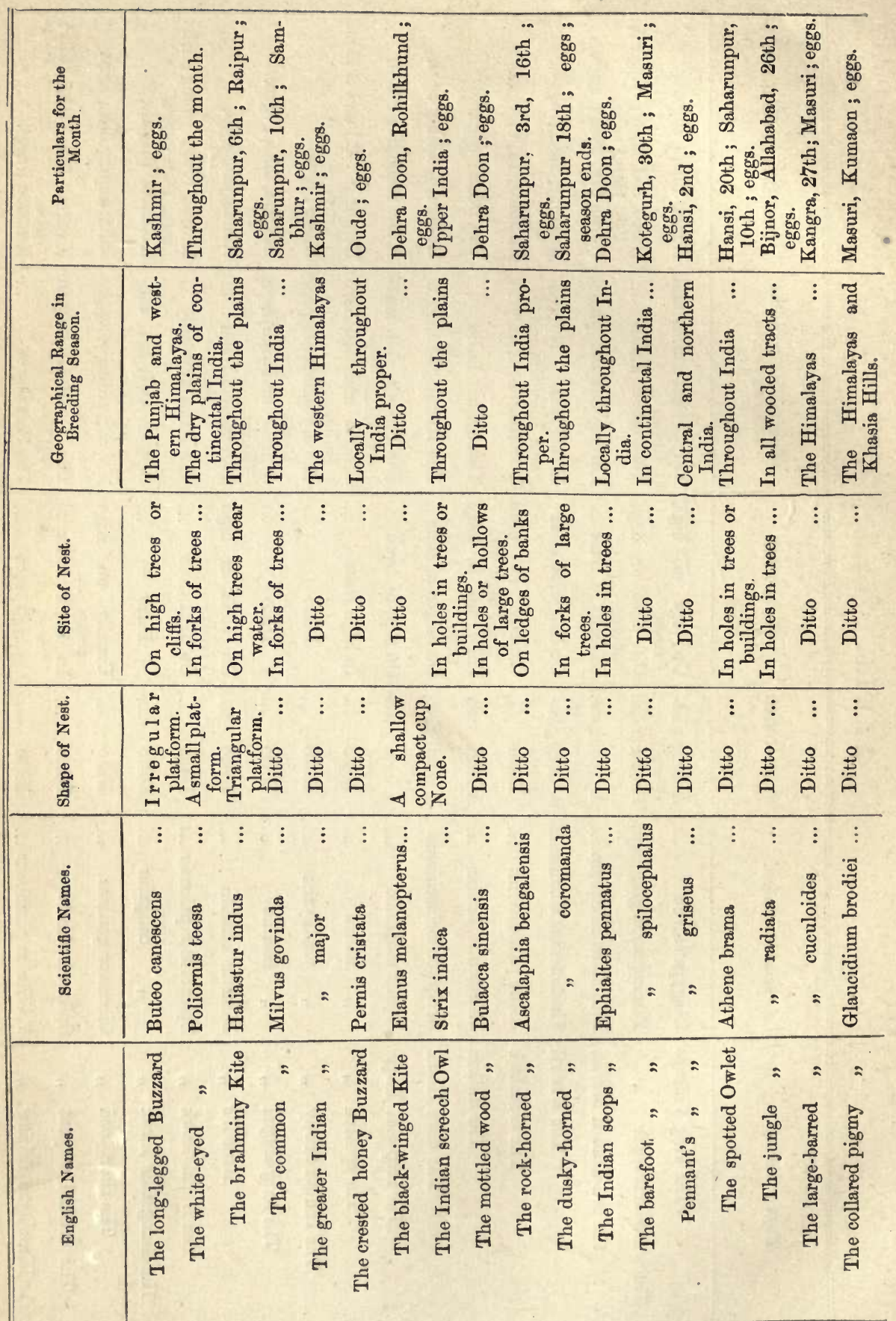




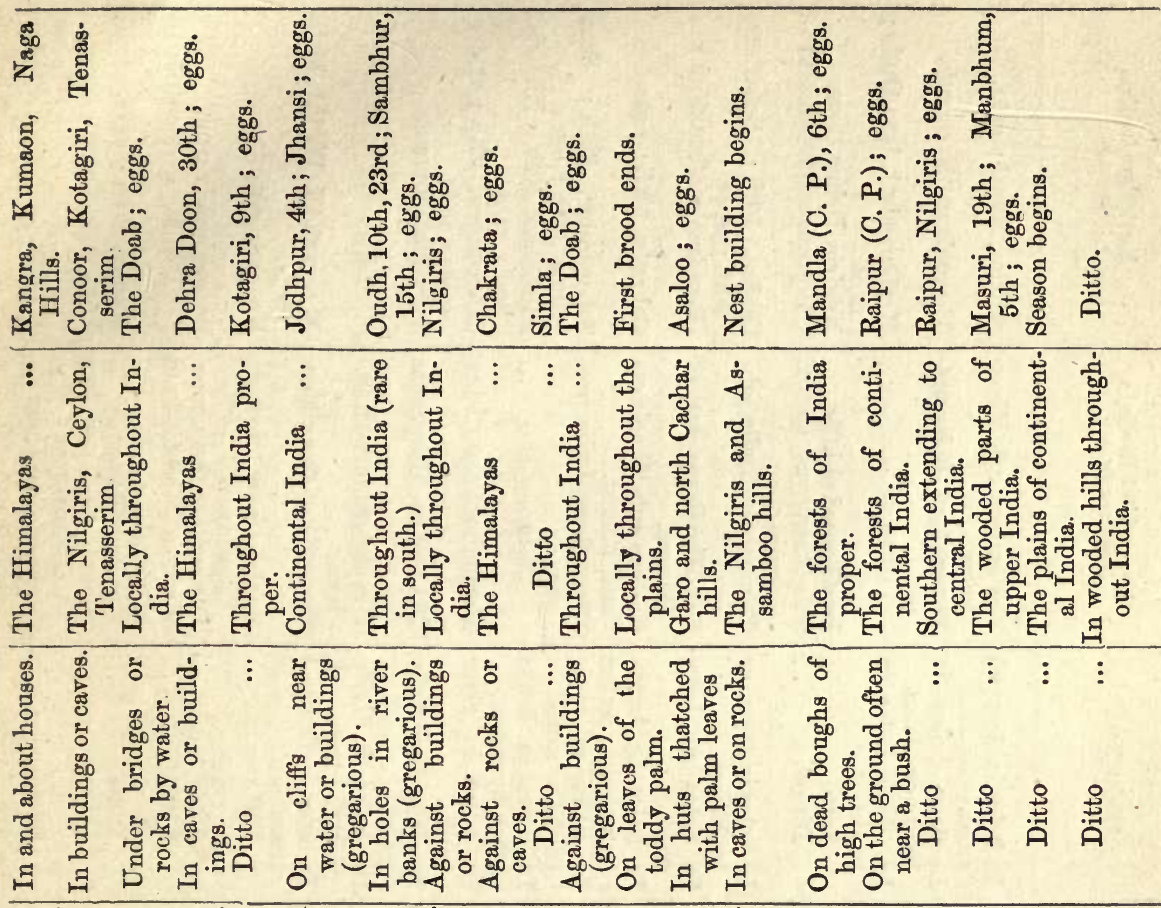

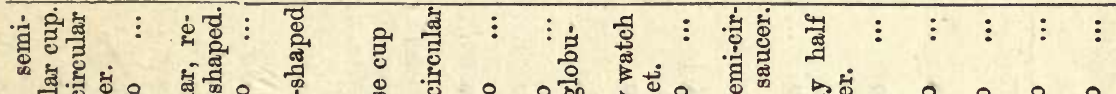

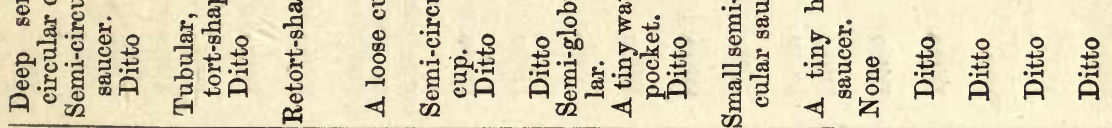

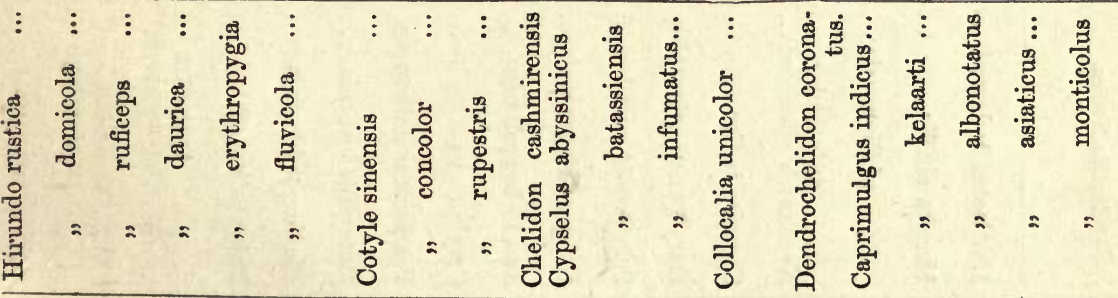

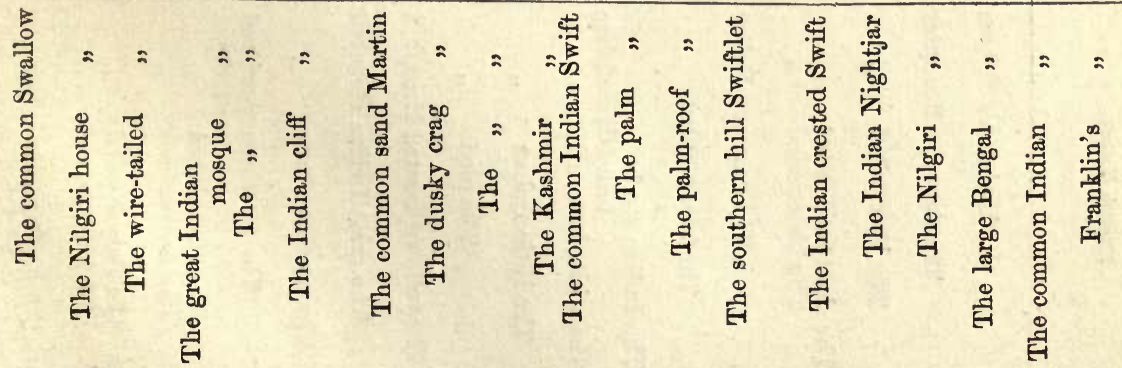

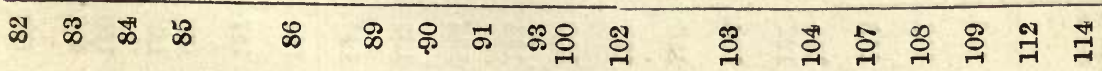




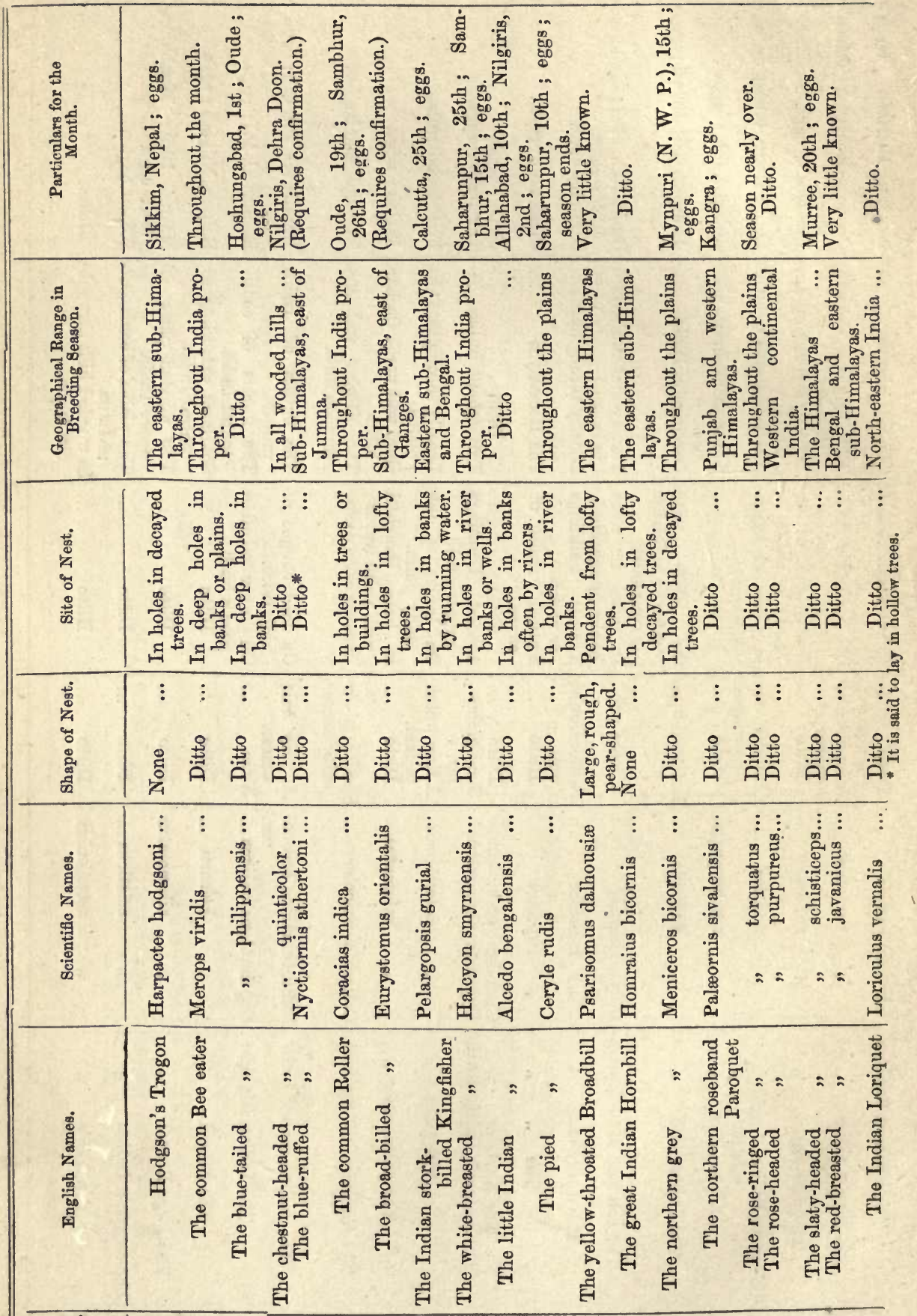

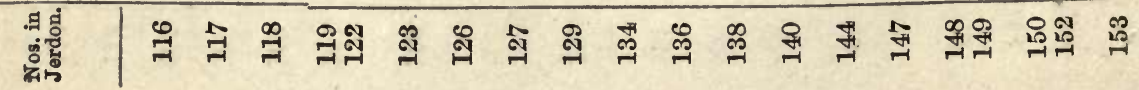




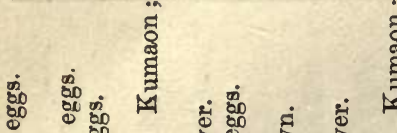

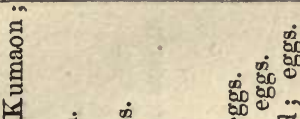

$\dot{\infty} \quad \dot{\infty}$

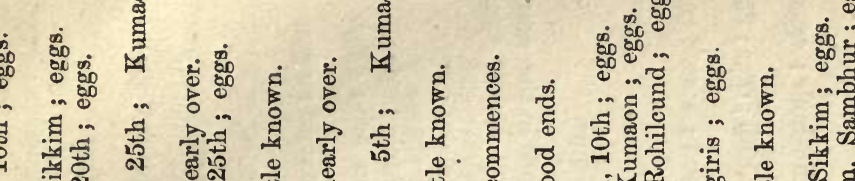

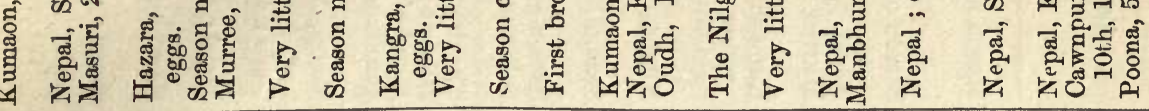

घ

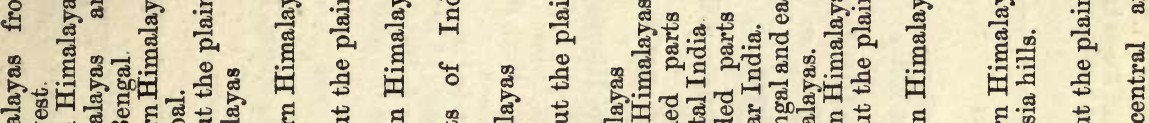

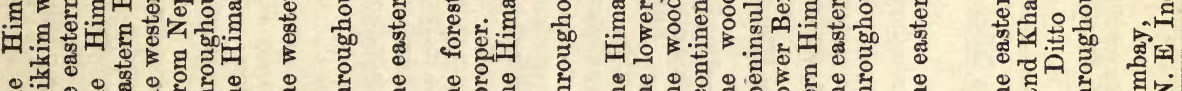

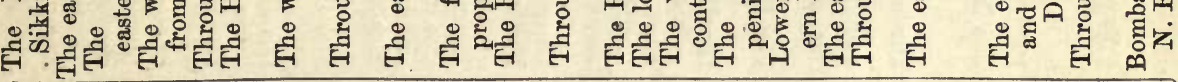

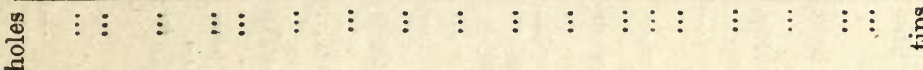

党 $\vdots$ : : : .ึ్లై

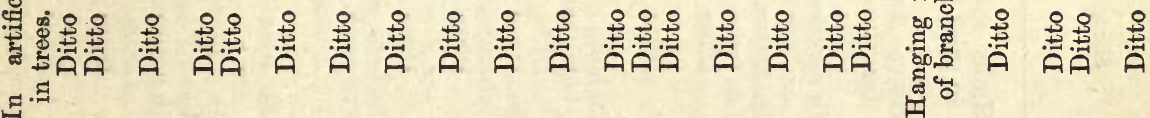

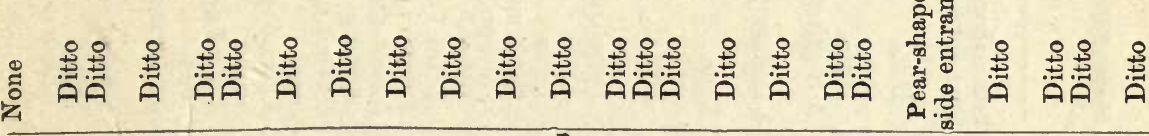

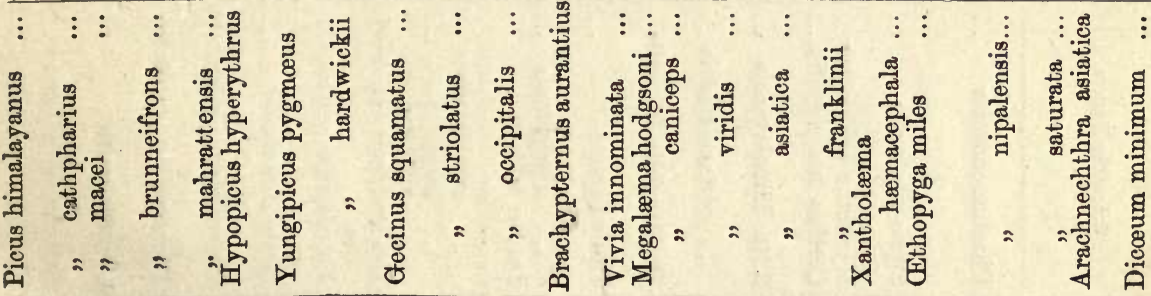

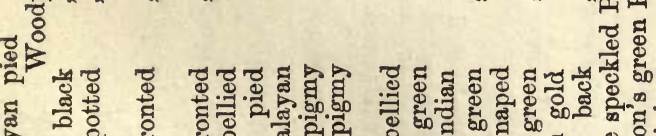

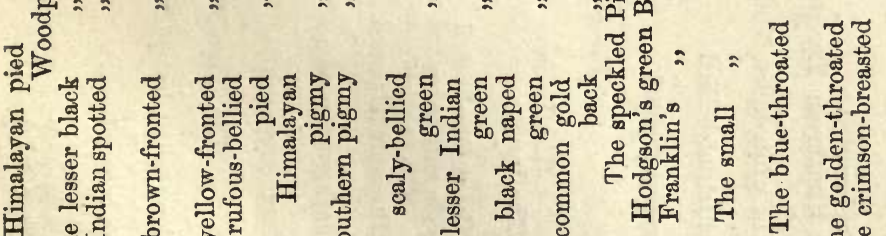

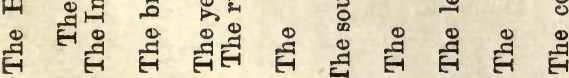

范

है

เี 


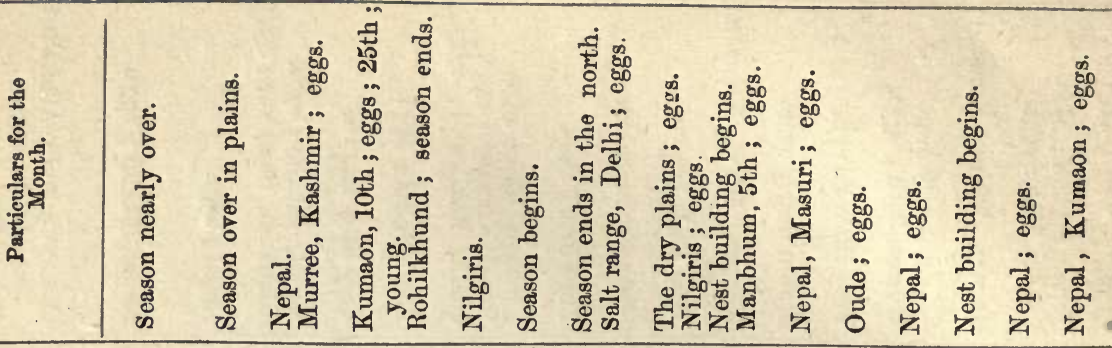

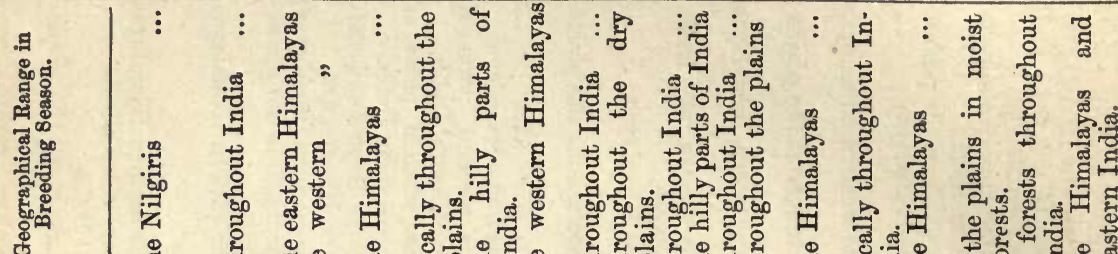

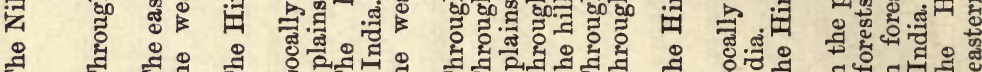

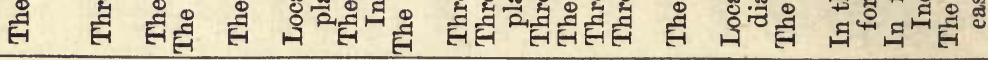

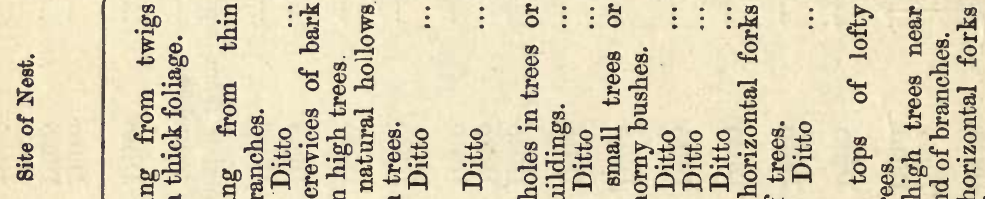

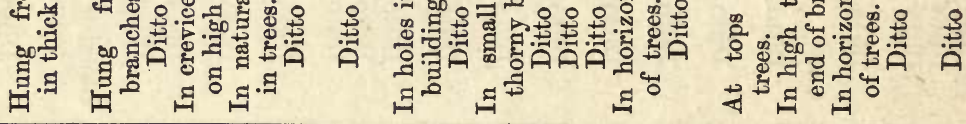

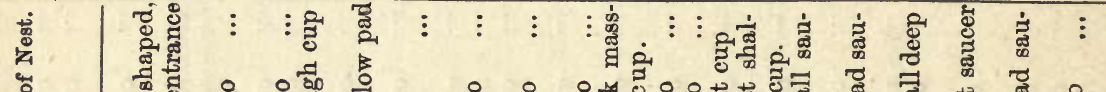

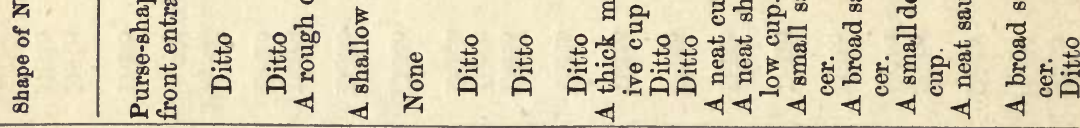

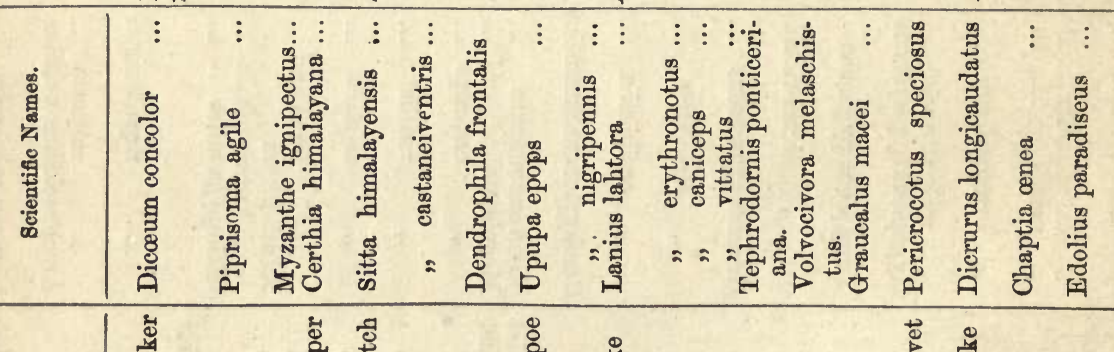

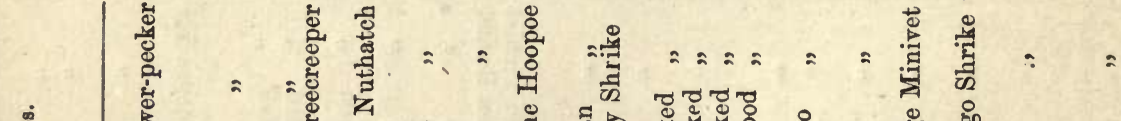

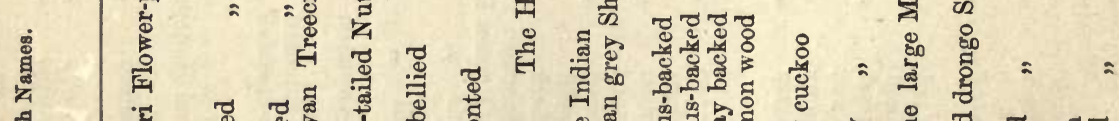

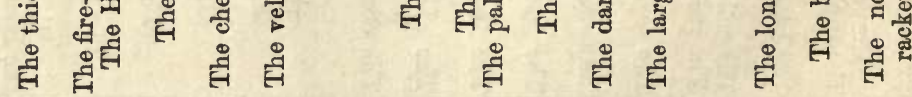

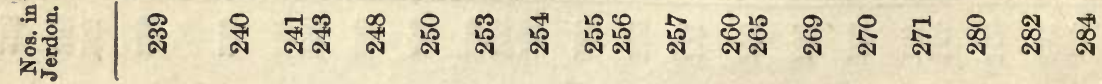




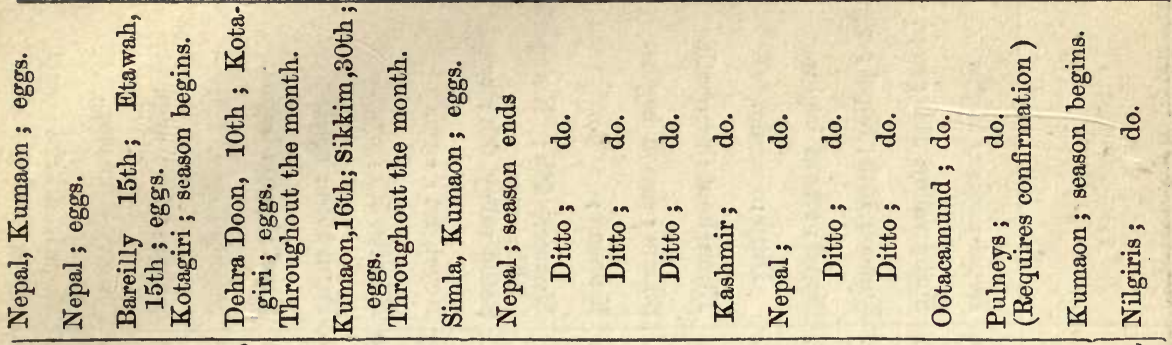

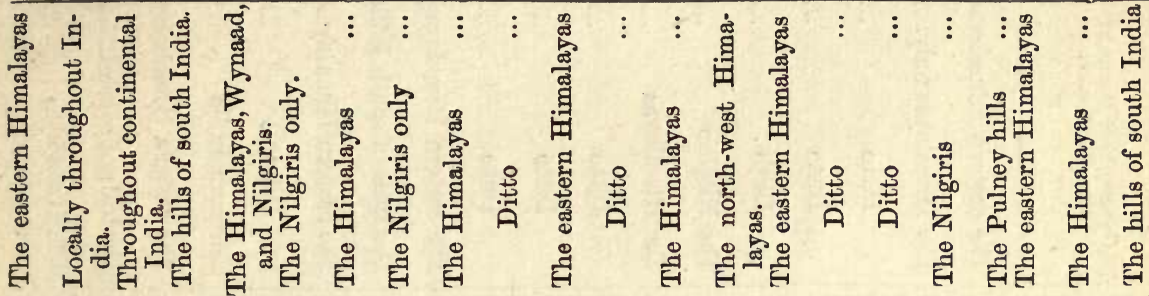

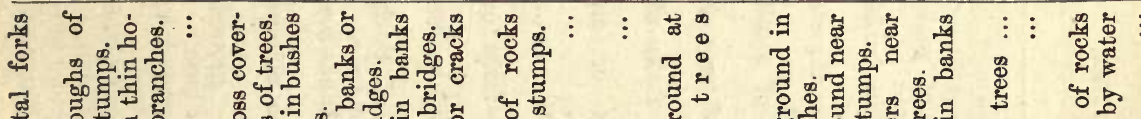

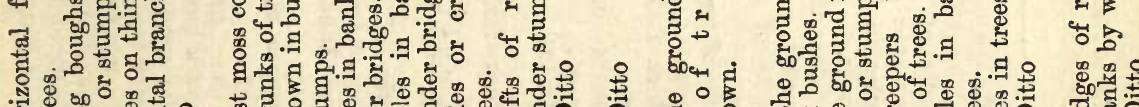

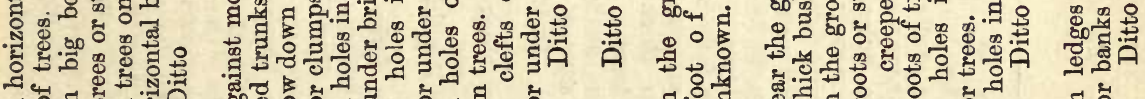

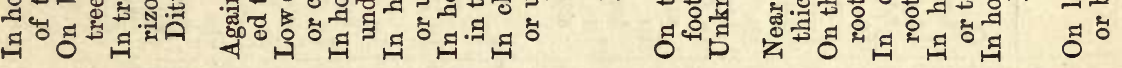

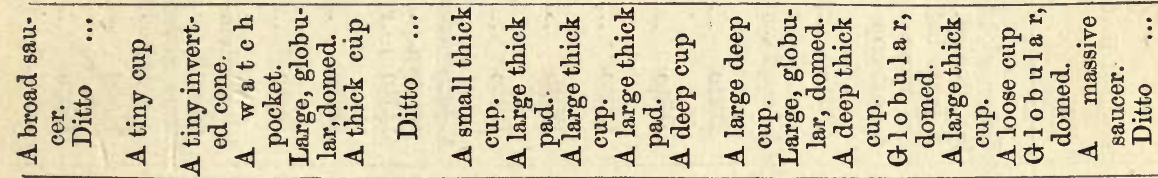

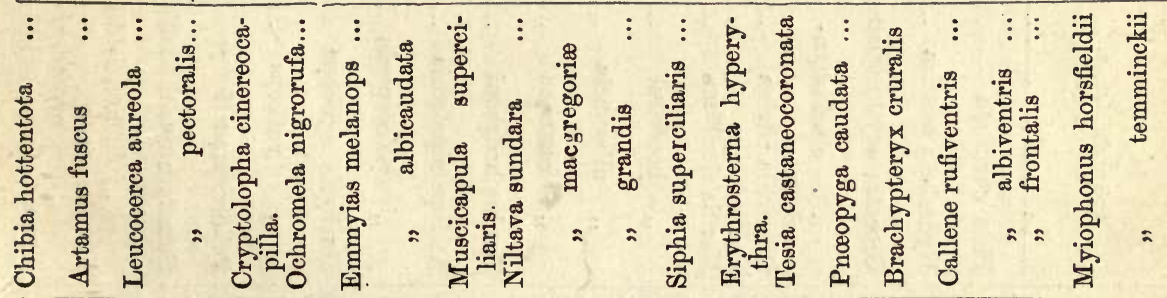

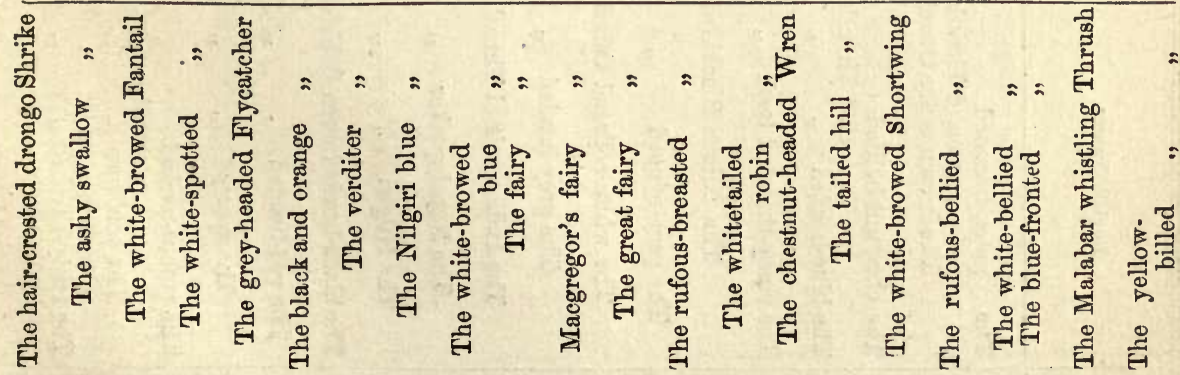

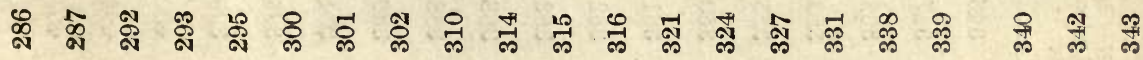




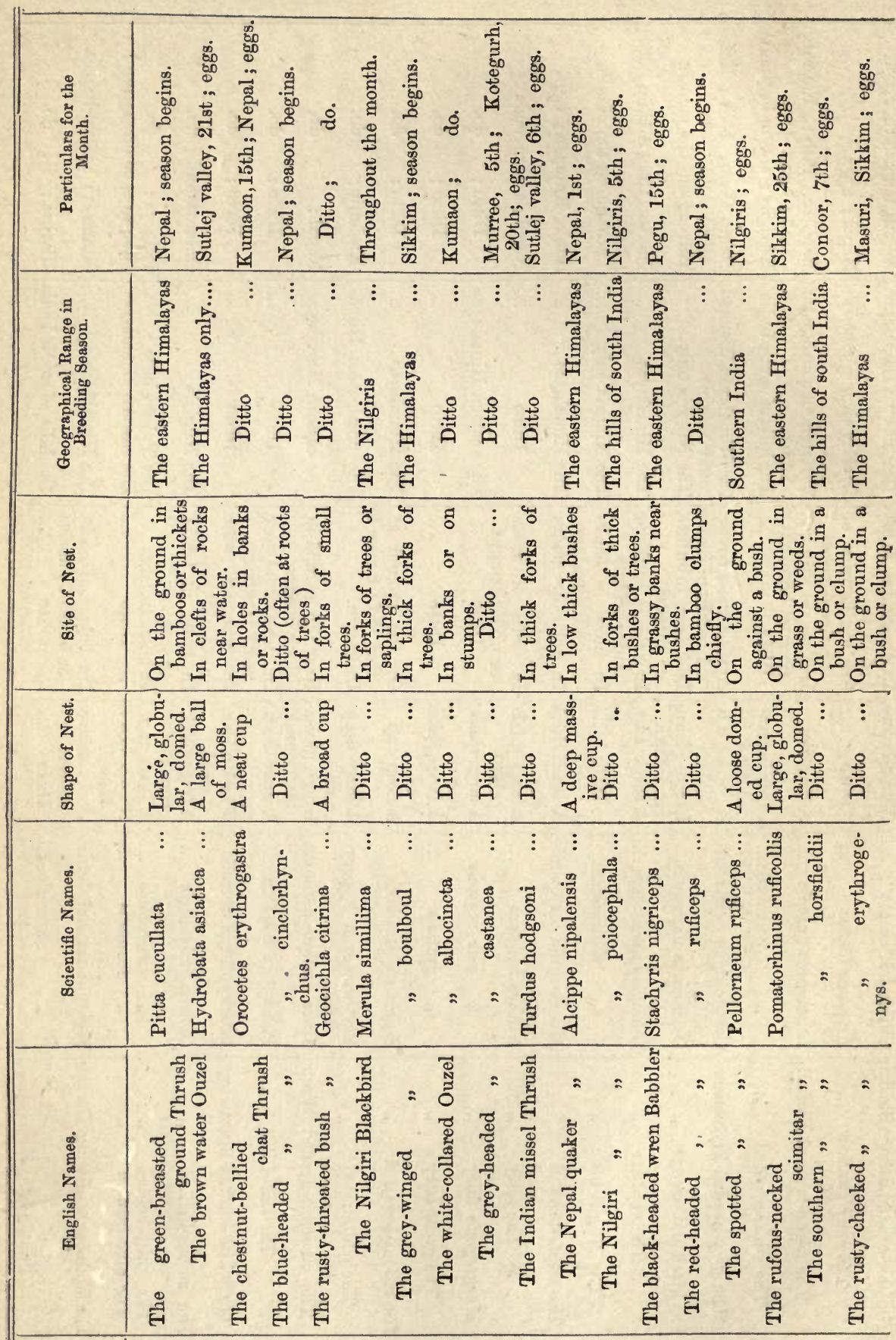

费育 


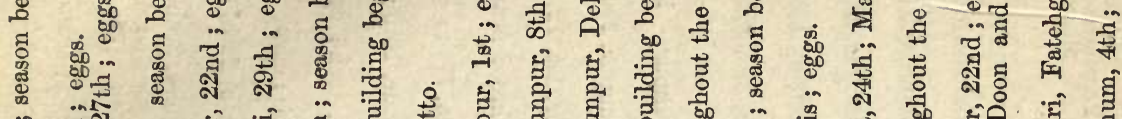

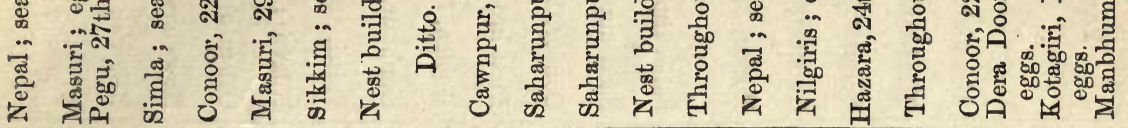

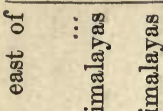

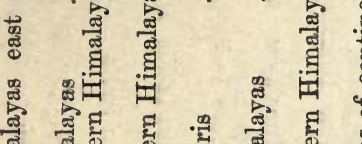

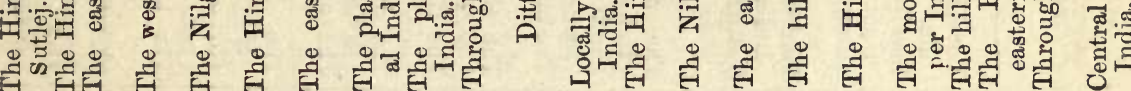

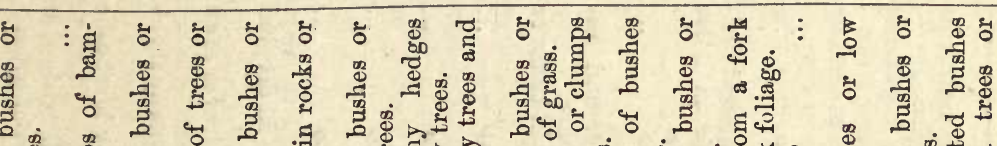

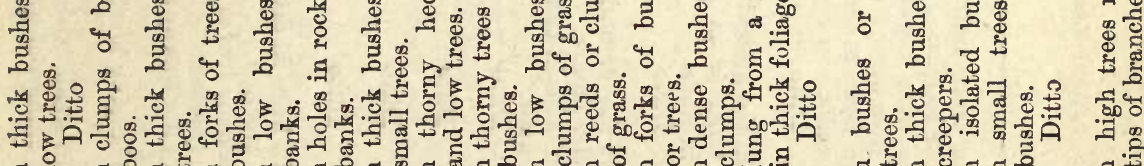
무

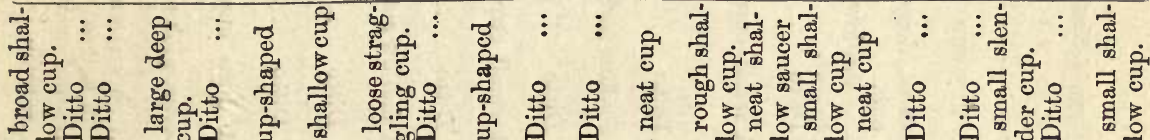

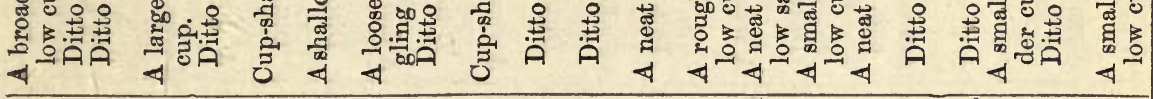

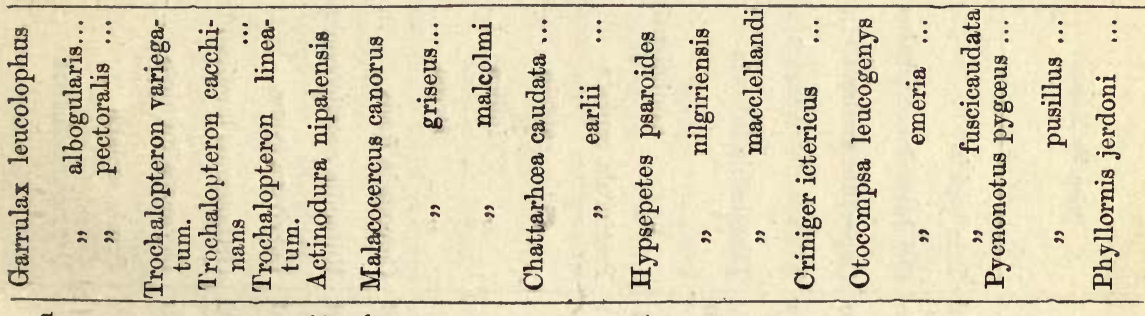

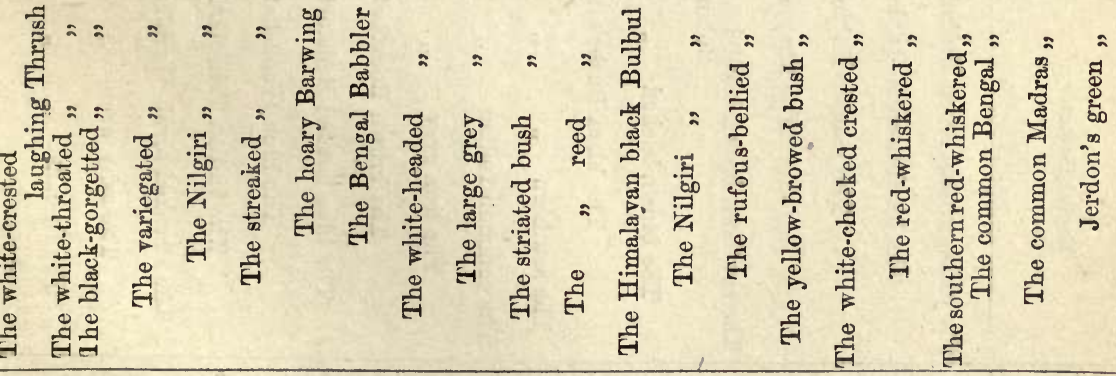

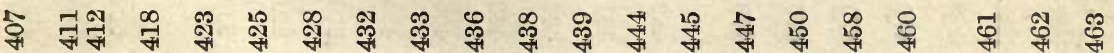




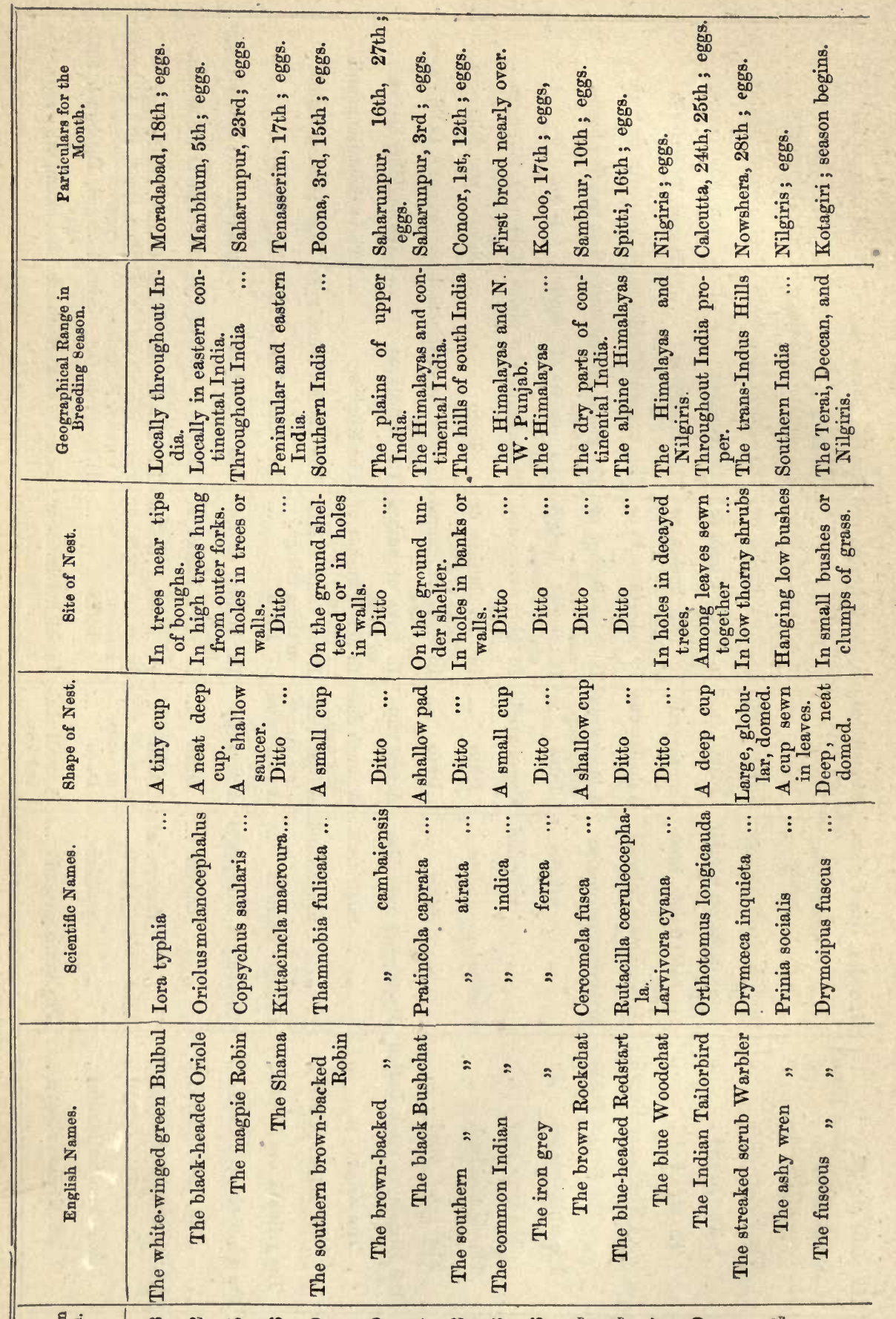

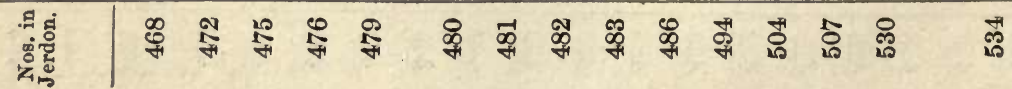




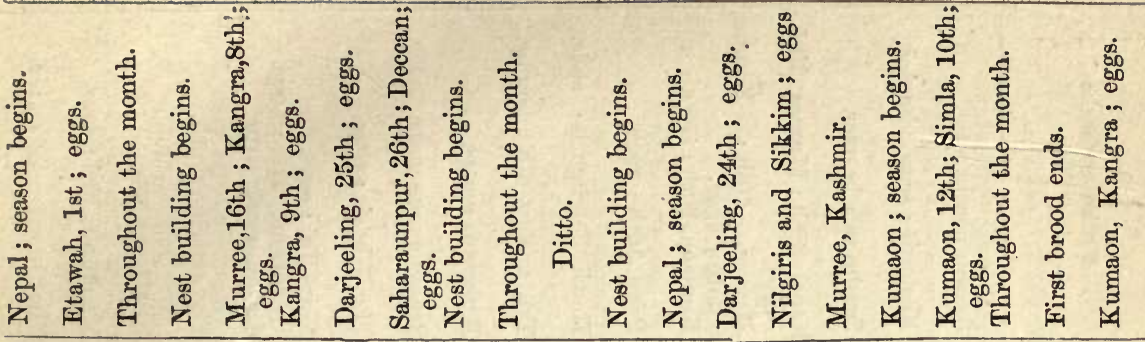

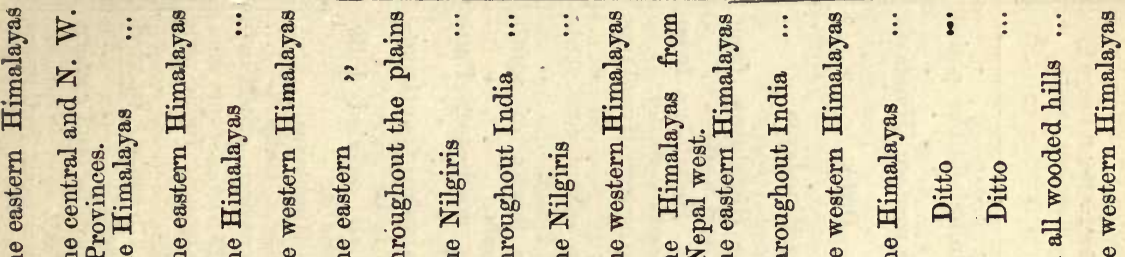

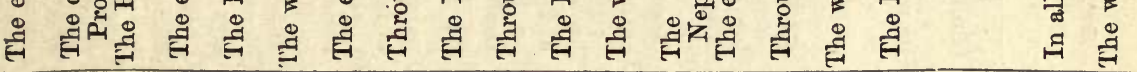
岁弯总

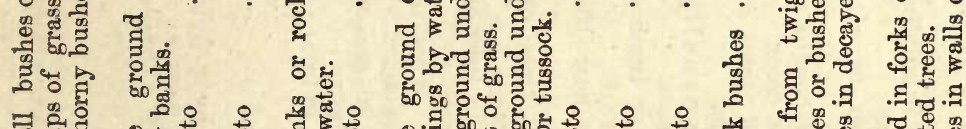

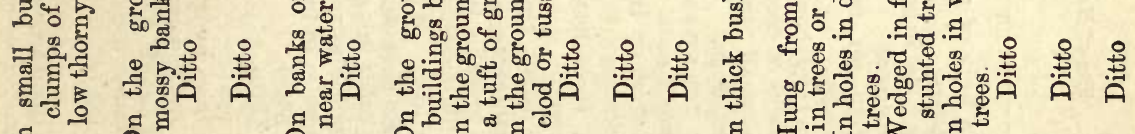
ฐ

产

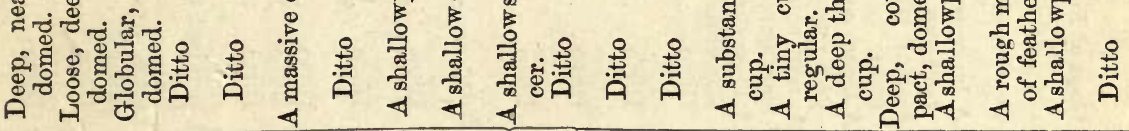

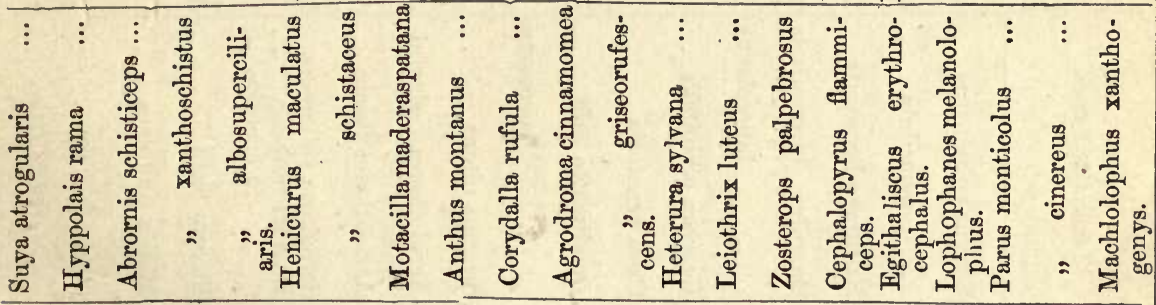

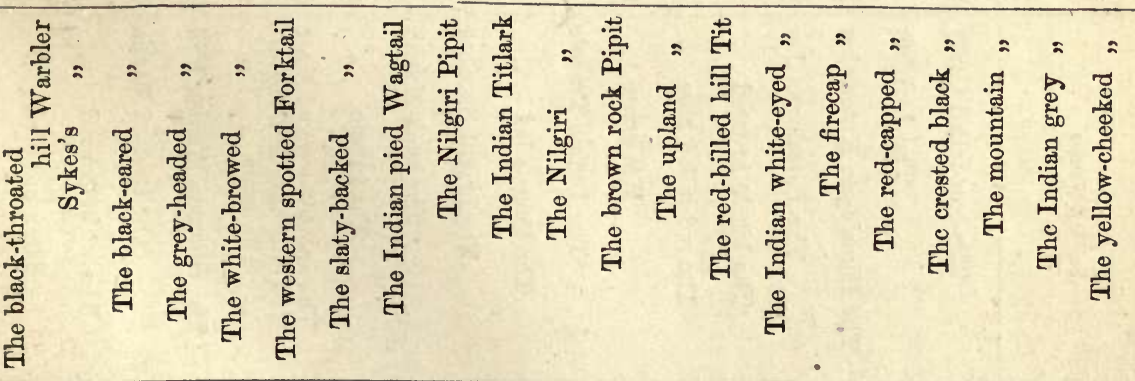

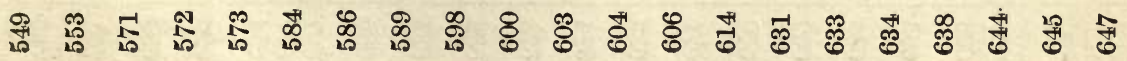




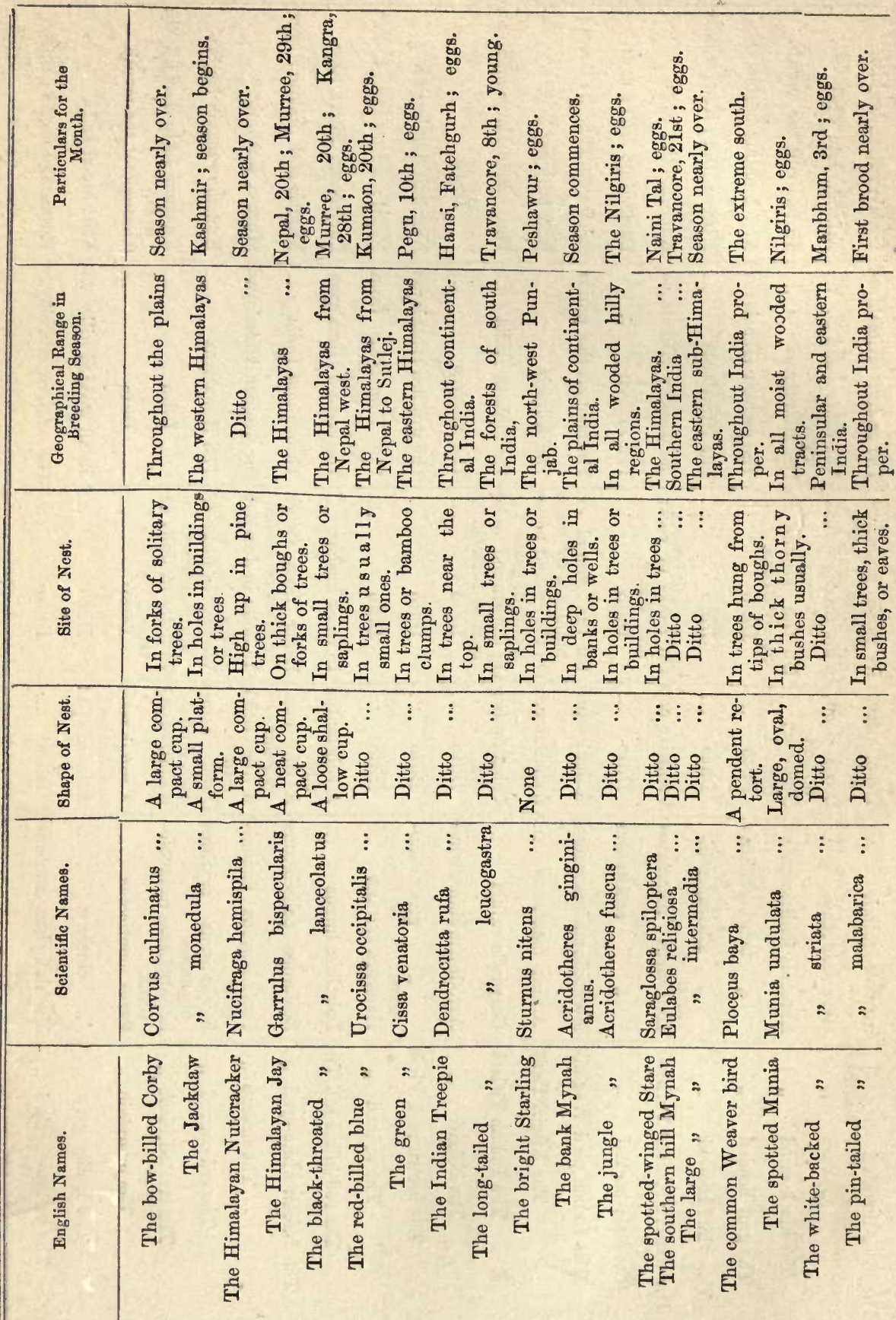

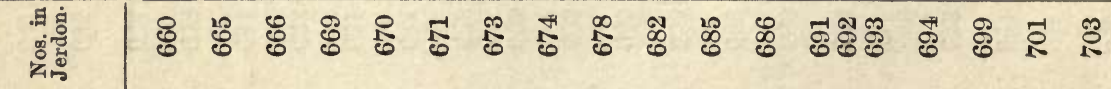




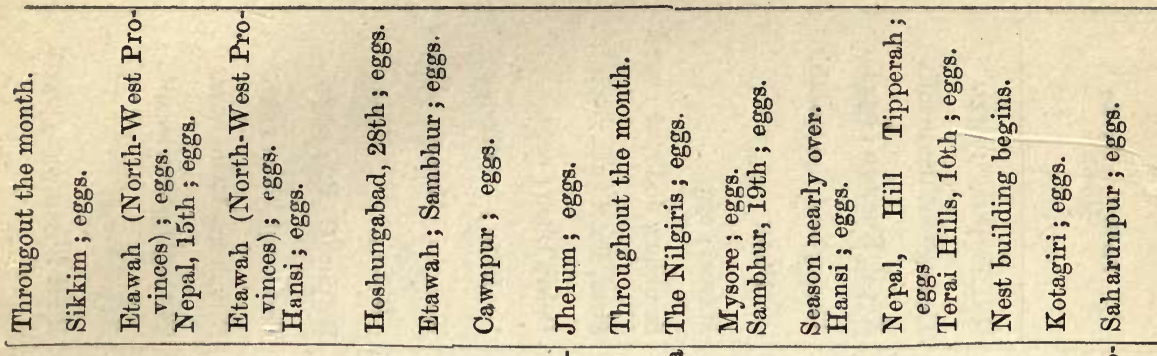

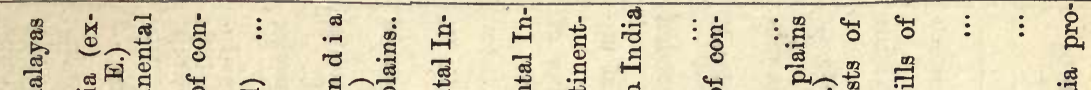

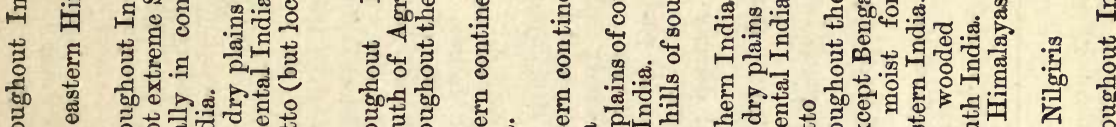

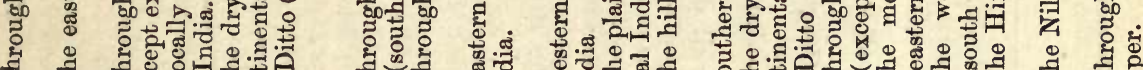
承 है

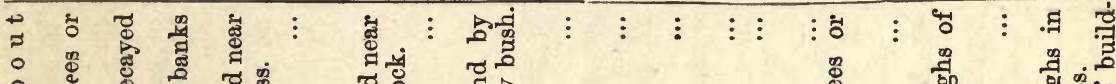

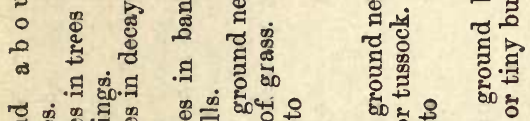

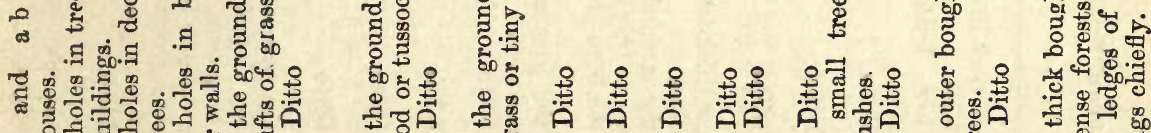
g्र

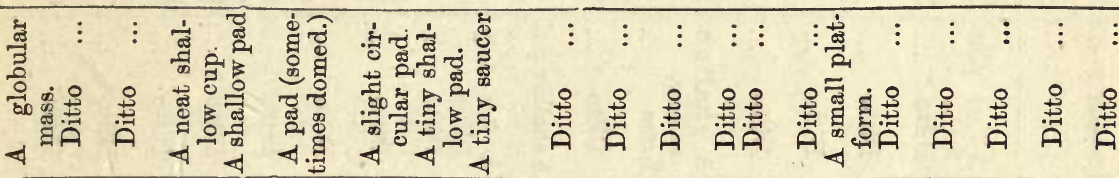

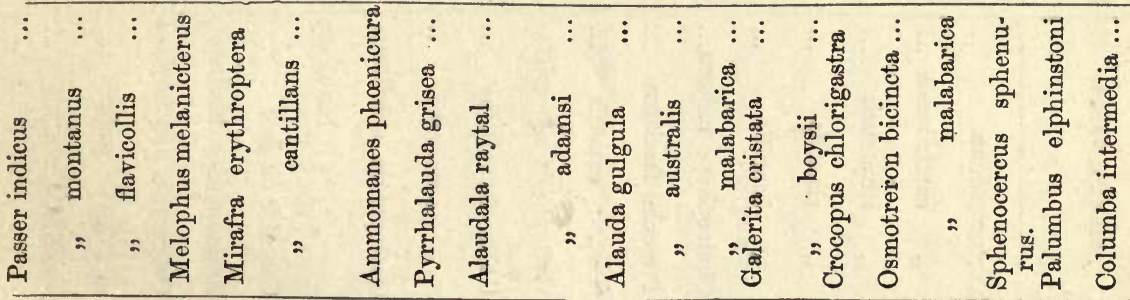

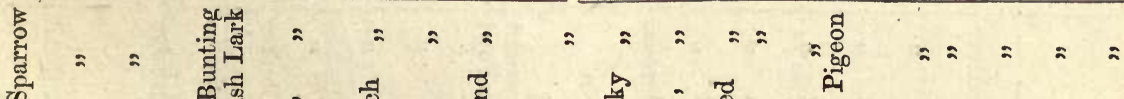

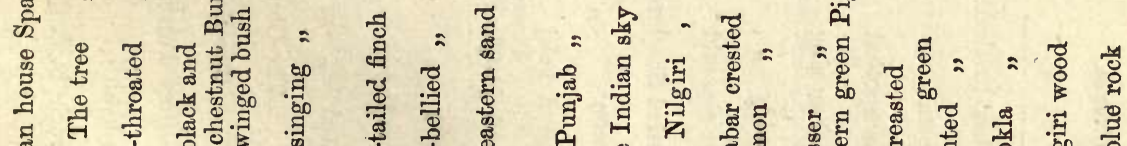

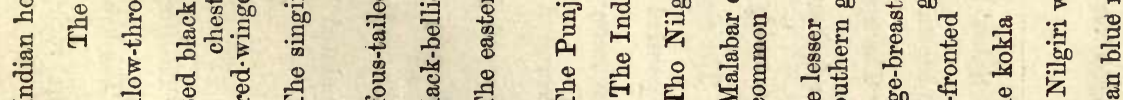

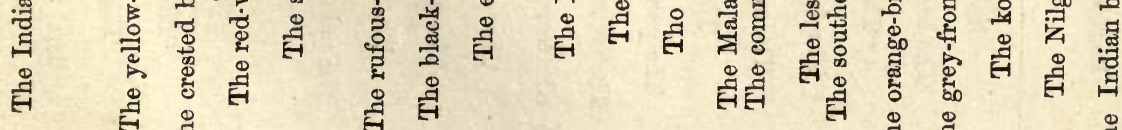
\& 


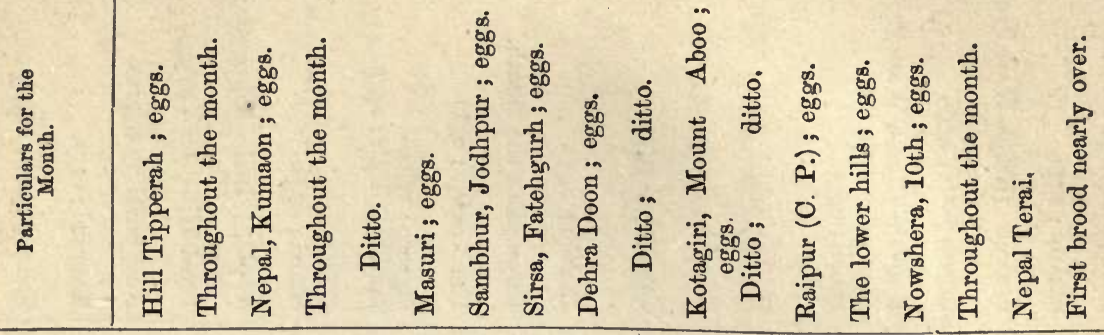

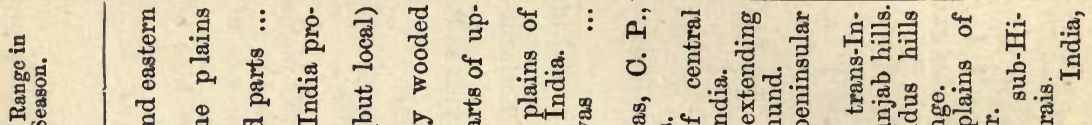

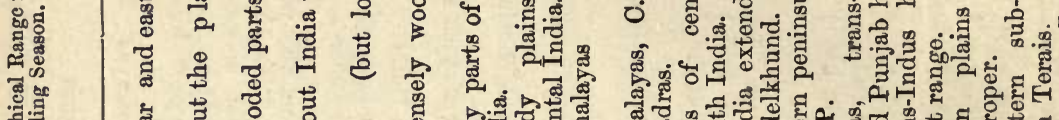

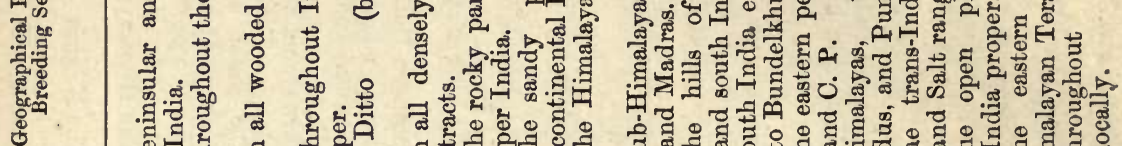

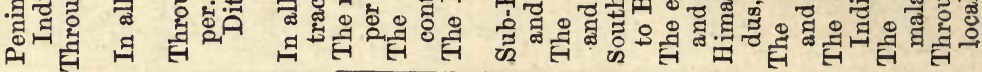
营

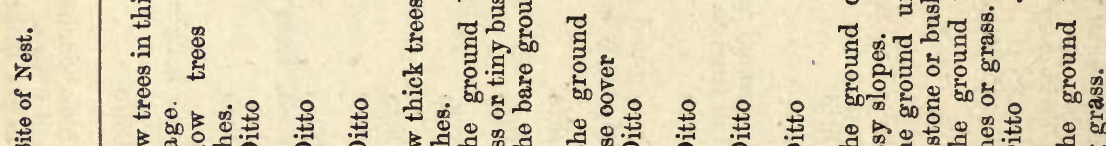

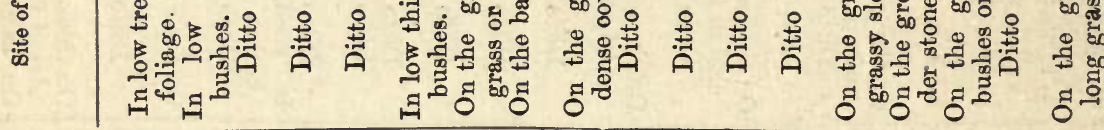

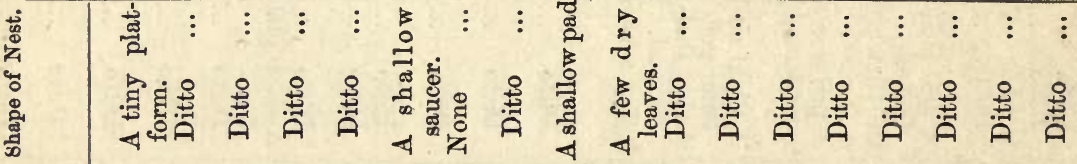

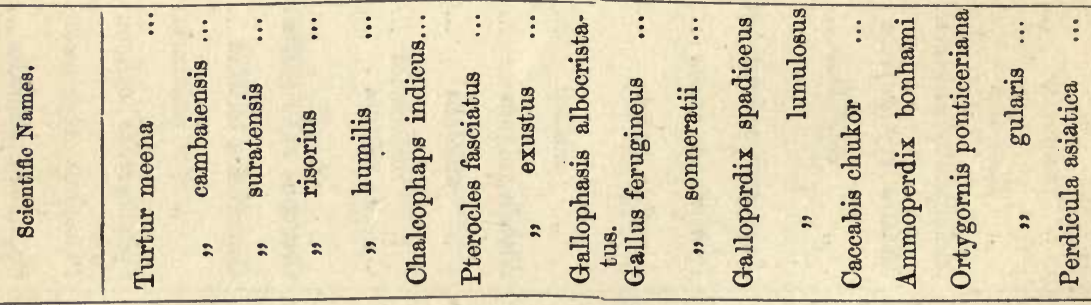

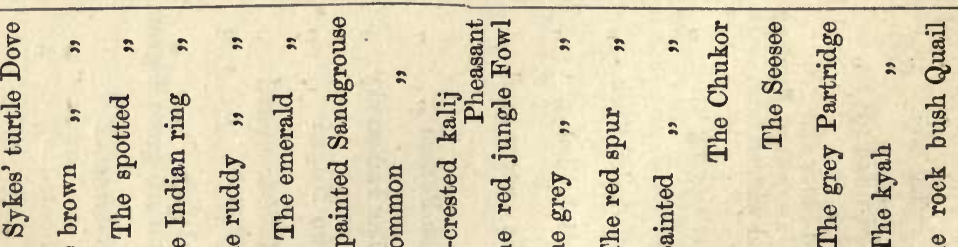

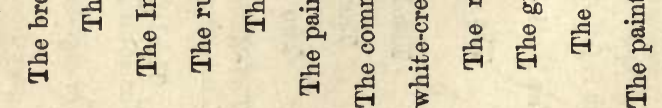
है

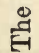

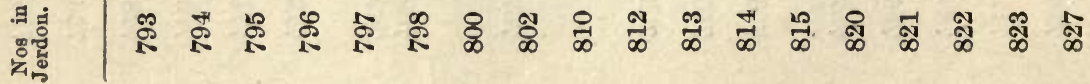




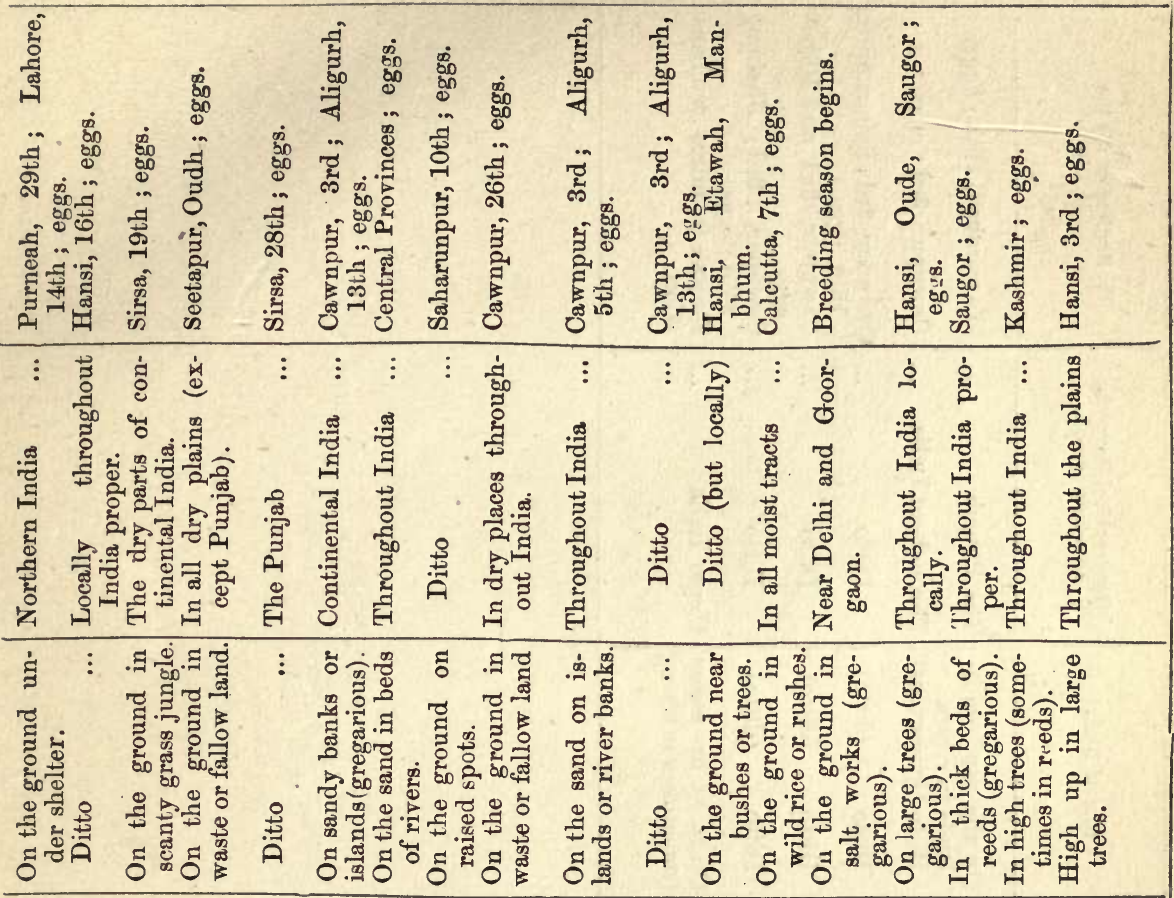

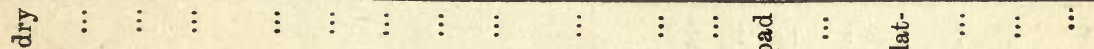

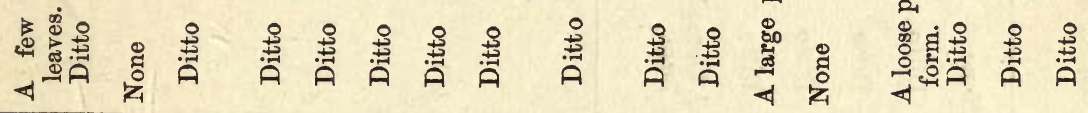

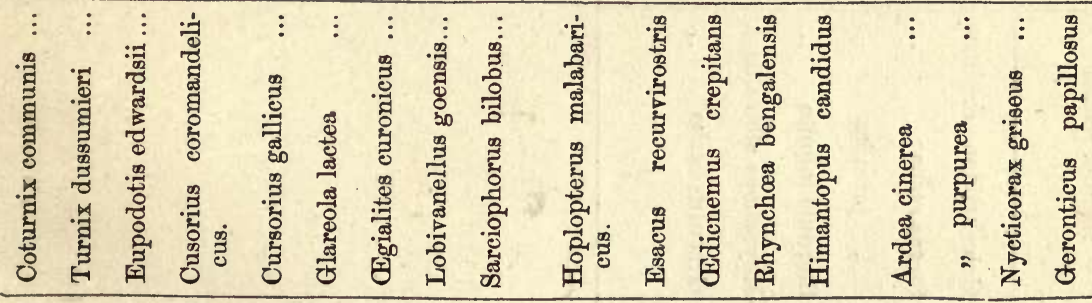

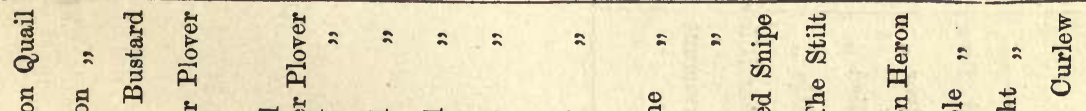

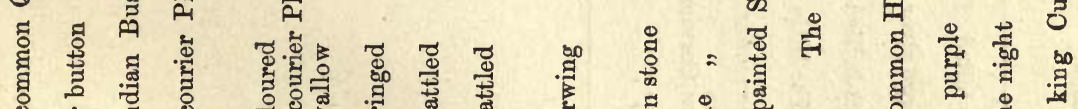

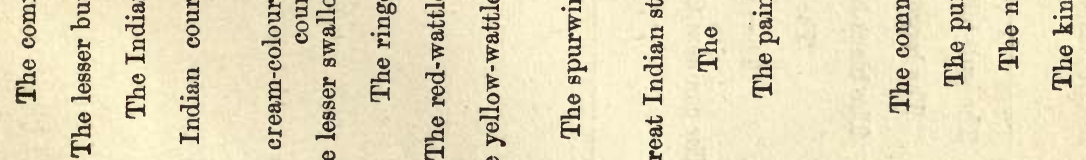

स हैं है

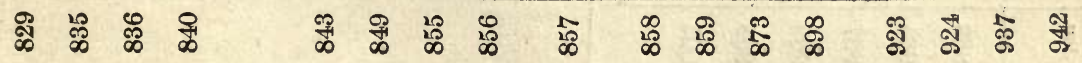




\begin{tabular}{|c|c|}
\hline 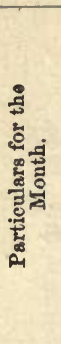 & 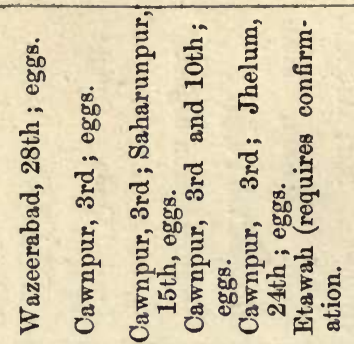 \\
\hline 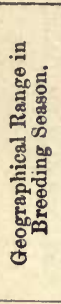 & 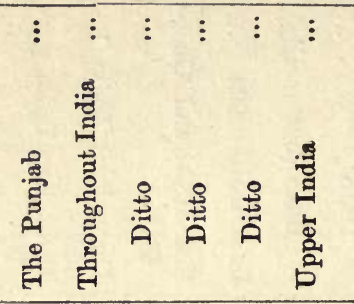 \\
\hline$\frac{\mathrm{g}}{\mathbf{m}}$ & 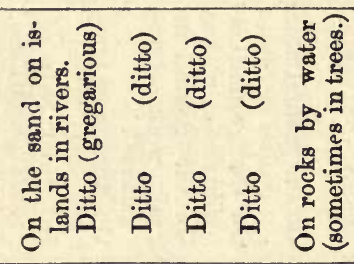 \\
\hline 离 & 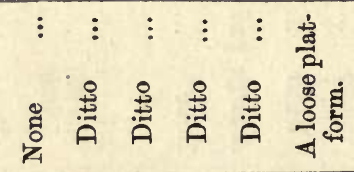 \\
\hline 离 & 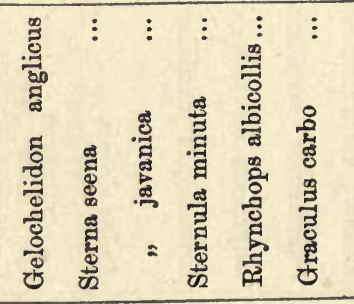 \\
\hline 离 & 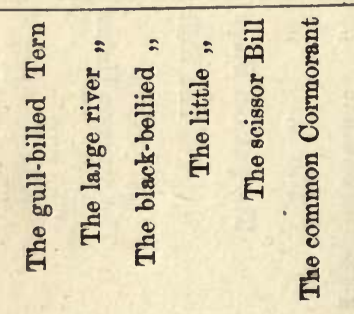 \\
\hline 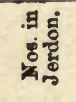 & 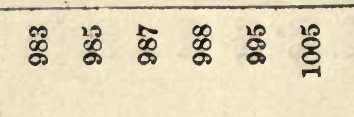 \\
\hline
\end{tabular}





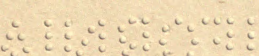

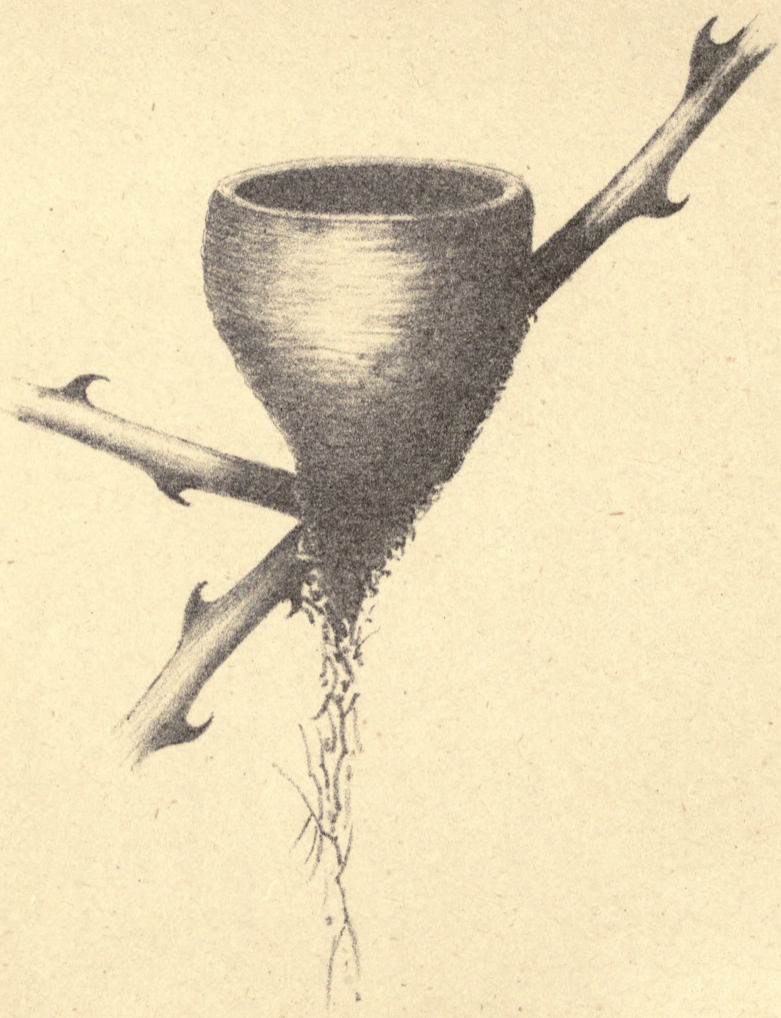

MARSHALL, DEL.

NEST OF THE WHITE-THROATED FANTAIL,

(Leucocerca fuscoventris.) 


\section{MAY.}

TH1s is in all parts of India the most prolific season of the year. Nearly thirty kinds of birds of prey are still breeding, and almost all the non-climbing birds have commenced to lay. The shrikes, the common drongo, the large grey babbler, the doves, and the red wattled plover are now breeding in all parts of the country.

In the Himalayas, the white scavenger vulture is still laying. The kestril, shikra, sparrow hawks, long-legged eagles, hawk eagles, serpent eagles, kites, wood owls, scops owls, owlets, mosque swallows, frogmouths, goatsuckers, European bee eater, rollers, and broadbills are laying. Most of the woodpeckers still have eggs, though for them it is late. The Marshall's barbet begins laying, while the other barbets still have eggs. The cuckoos, honey suckers, flowerpeckers, tree creepers, nuthatches, hoopoes, shrikes and drongos of all kinds, flycatchers, wrens, shortwings, thrushes of all kinds, blackbirds, ouzels, wren babblers, laughing thrushes, barwings, bulbuls, robins, bushchats, woodchats, water robins, reed warblers, tailor birds, warblers of all kinds, golden-crested wrens, forktails, wagtails, pipits, all the hill tits (Leiotrichinc), true tits, bedge sparrows, crows, jays, magpies, starlings, mynahs, sparrows, buntings, grosbeaks, skylarks, pigeons, doves, pheasants, grouse, partridges, quail, plovers, woodcock, sandpipers, coots, bittern, herons, geese, ducks, and grebe have all begun to lay: while the rosy minivet, the red-billed wren warbler, the magpie sibia, the white-tailed ruby throat, the paddy field warbler, strong-footed "hill warbler, the golden-breasted hill tit, Hodgson's munia, the white-capped bunting, the speckled wood pigeon, Baillon's crake, the little bittern and the whiskered tern have all begun to pair and build.

In the PUnJaB, the red-headed merlins, the sand martin, the Egyptian bee eater, the rose-headed paroquet, the speckled piculet, the common bulbul, the magpie robins, the common bushchat, the bright starling, the pied mynah, the pin-tailed munia, the desert finch lark, the sand larks, the crested lark, the common sandgrouse, the black partridge, the chukor, the seesee, the grey partridge, the big bustard, the courier plover, the great stone plover, the stone 
plover, the stilt, the king curlew, and the gull-billed tern are all laying: while the white-necked storks are pairing and building.

In the North-West Provinces the true eagles, buzzards, kites, screech owl, scops owl, jungle owlet, wire-tailed swallow, goatsuckers, rollers, white-breasted and little kingfishers, hornbills, koel, concal, sirkeer, purple honey sucker, fantails, babblers, bulbuls, orioles, robins, pied wagtails, treepies, mynahs, sparrows, bush larks, finch larks, skylarks, green pigeons, rock pigeons, sandgrouse, jungle fowl, partridges, plovers, and common cormorants have eggrs; and Stewart's wren warblers, the Bengal bush larks, white-necked storks, shell $i b i s$, and white ibis are pairing and building.

In Bengal, the spotted eagle, the crested swift, the whitebreasted and stork-billed and little kingfishers, the amethystrumped honey suckers, king crows, the yellow-breasted and red-capped wren babblers, the striated marsh babblers, red-whiskered bulbuls, the black-headed oriole, the shama, titlark, sparrows, and many other kinds are laying. The lesser concal, the Bengal bushlark, the florikin, the yellow bittern, and the pink-headed duck are commencing to pair and build.

In Central India, the shikra, the lesser harrier eagle, the whiteeyed buzzard, the Nilgiri nightjar, the blue-tailed bee eater, the blue redbreasts, the striated marsh babblers, the white-eared crested bulbuls, the brown-backed robins, the brown rock chats, pied wagtails, green amadavats, the sand larks, the painted sandgrouse and the common sandgrouse, the grey jungle forwl, the spur fowl, courier plovers, wattled plovers, the brown rails, purple herons, and some others have got eggs. The white ibis are pairing and building torvards the end of the month.

In Southern India, the house and mosque swallows are laying. Also the crag martins, swiftlets, ghat nightjars, small green barbets, crimson-breasted barbets, long-tailed drongos, white-spotted fantails, grey-headed and black and orange flycatchers, blue redbreasts, short wings, blackbirds, Nilgiri quaker thrushes, scimitar babblers, laughing thrushes, babblers, black bulbuls, yellow-browed bush bulbuls, bushchats, the fuscous and ashy wren warblers, the Nilgiri pipit and Nilgiri tit lark, the white-eyed tit, the grey tit, the black crows, the common crows, the hill mynah, the weaver bird, the spotted munia and Indian amadavat, the skylark, the grey jungle fowl, the red spur fowl, and the little grebe have all got eggs during the month. Towards the end of it, the orange minivets, black-headed 
quaker thrush, white-browed bush bulbuls, and peafowl commence pairing and building.

In the Andamans and NicoBars, the black-naped ternlet is laying, and the sea terns and gulls begin to congregate for breeding purposes on the rocky islands in the Indian ocean and Persian gulf. The island of Astolah is well known as a breeding place. 


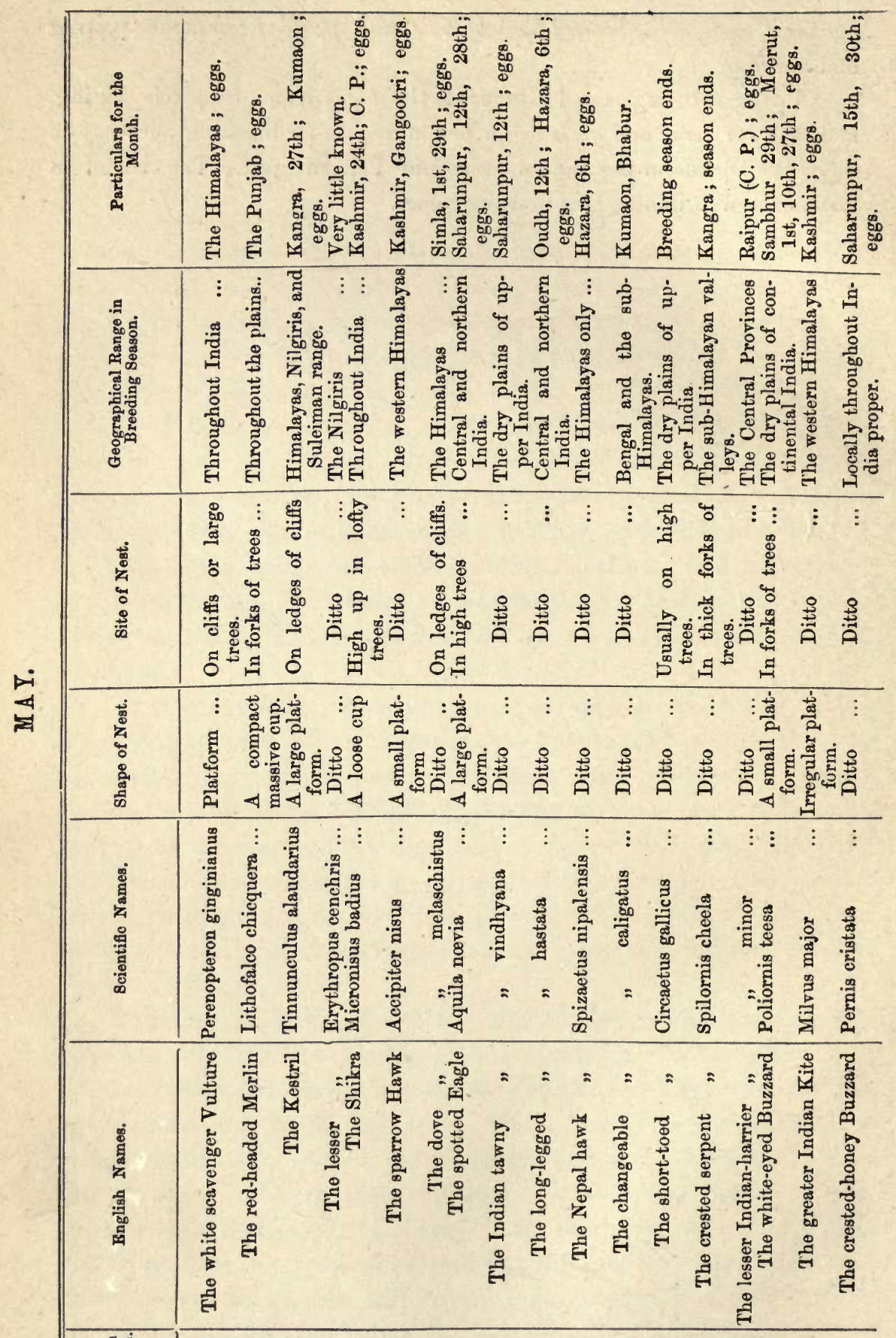

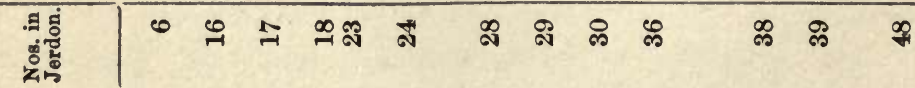




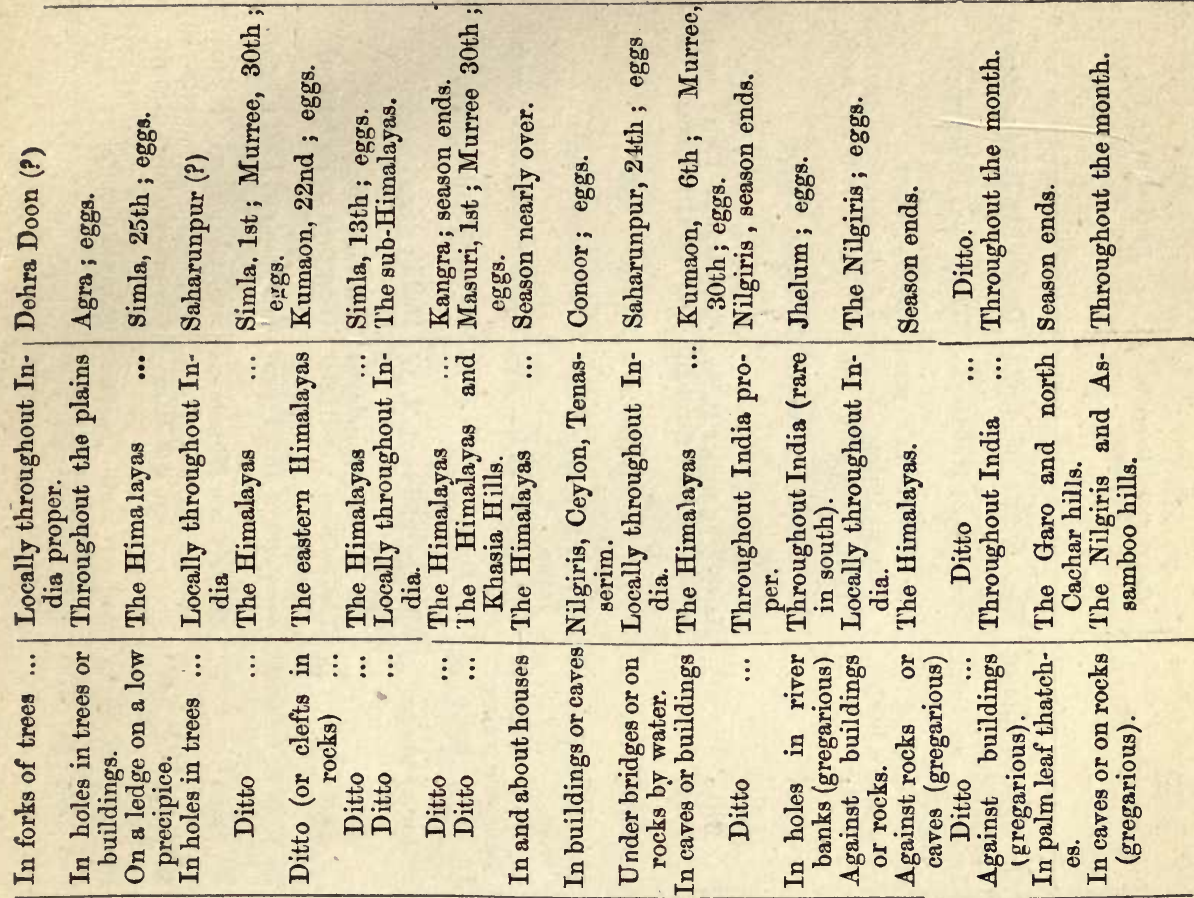

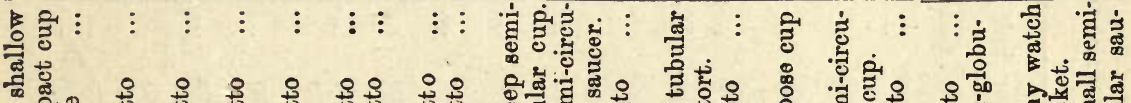

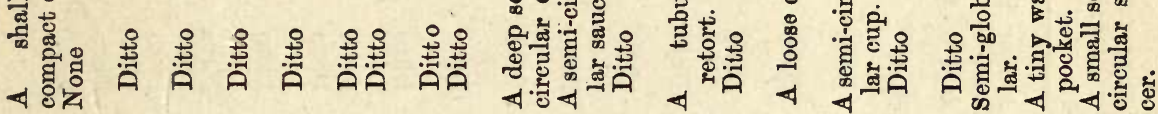

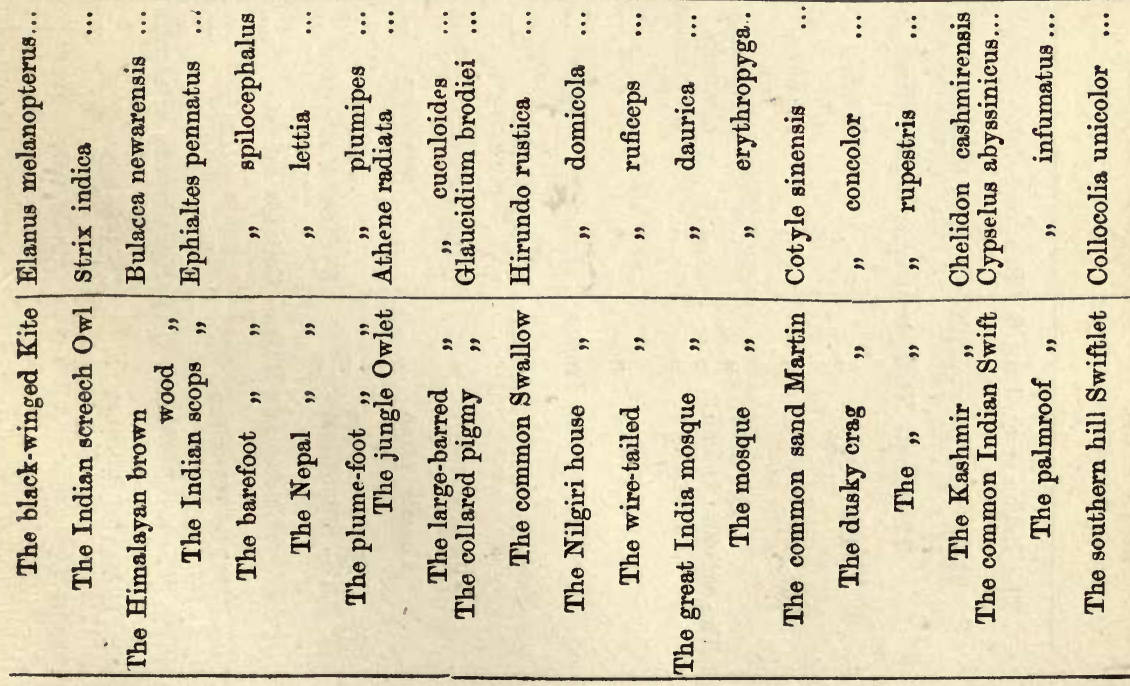

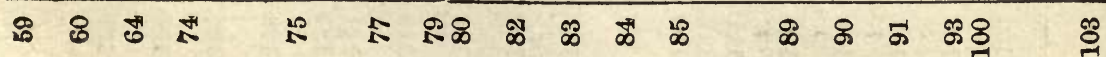




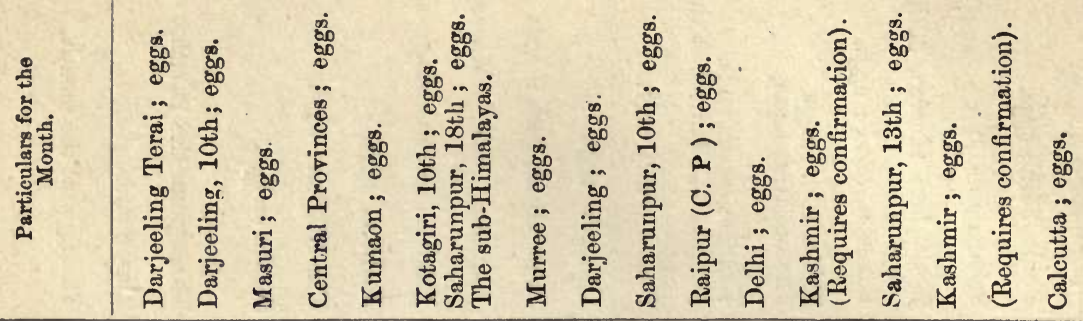

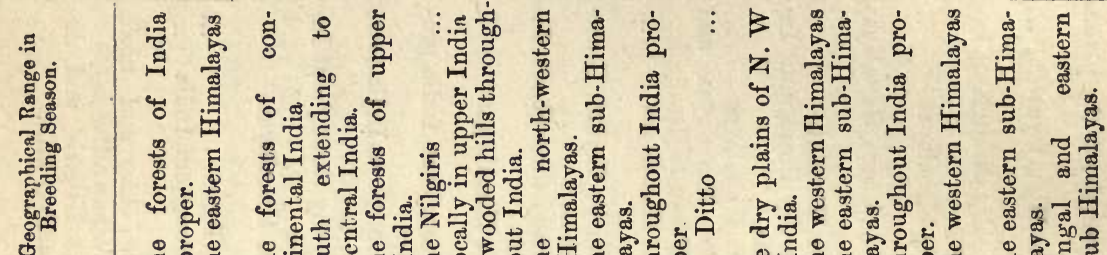

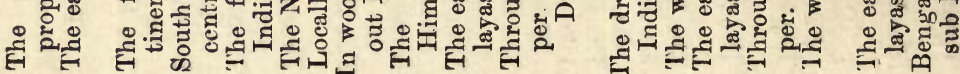

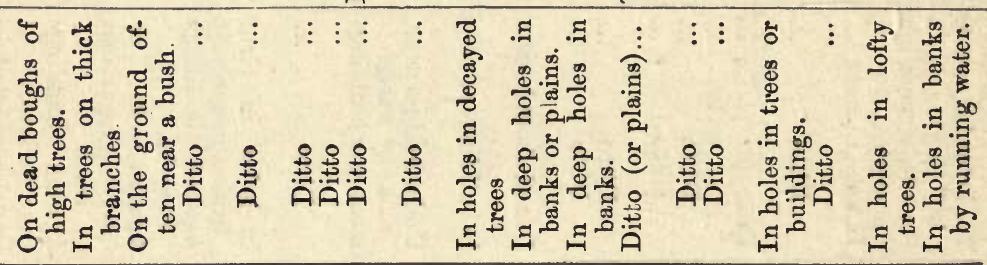

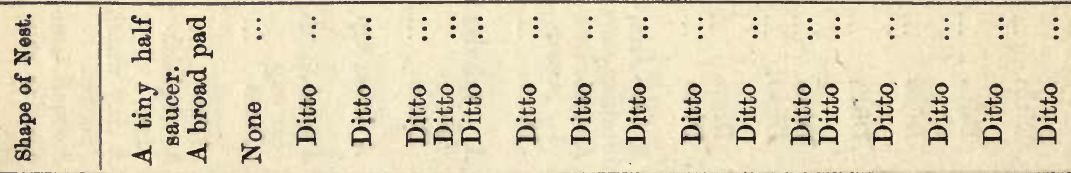

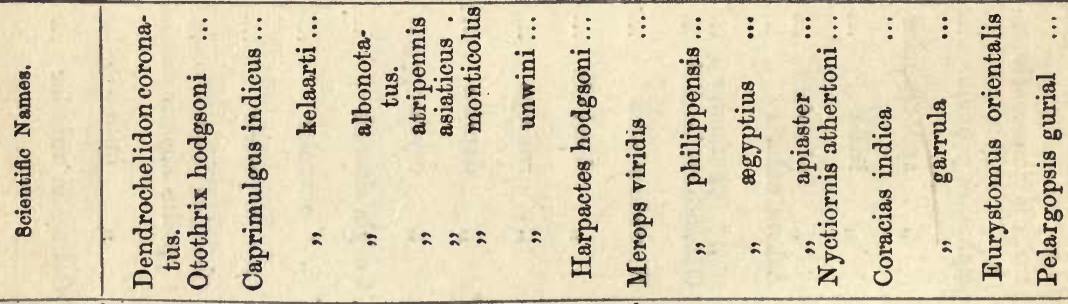

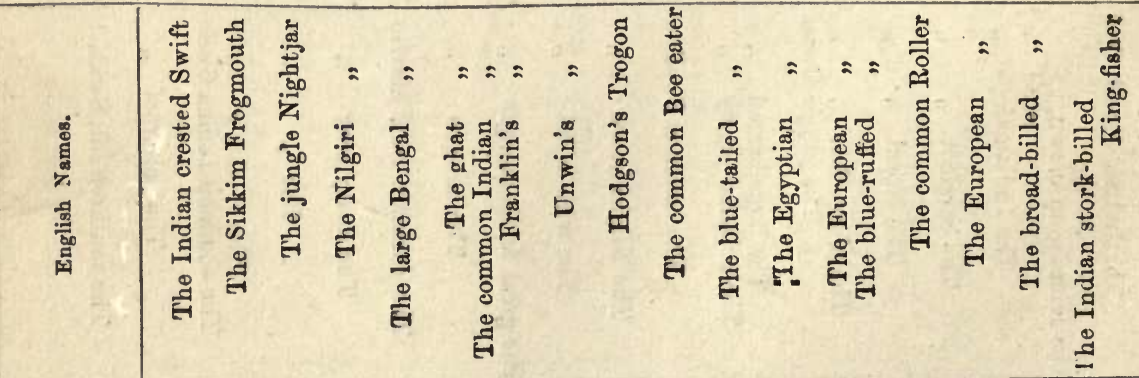

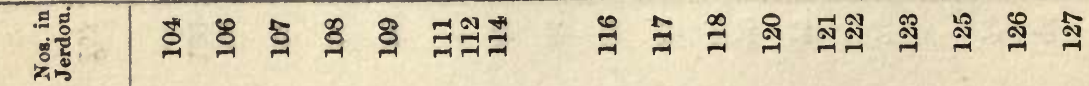




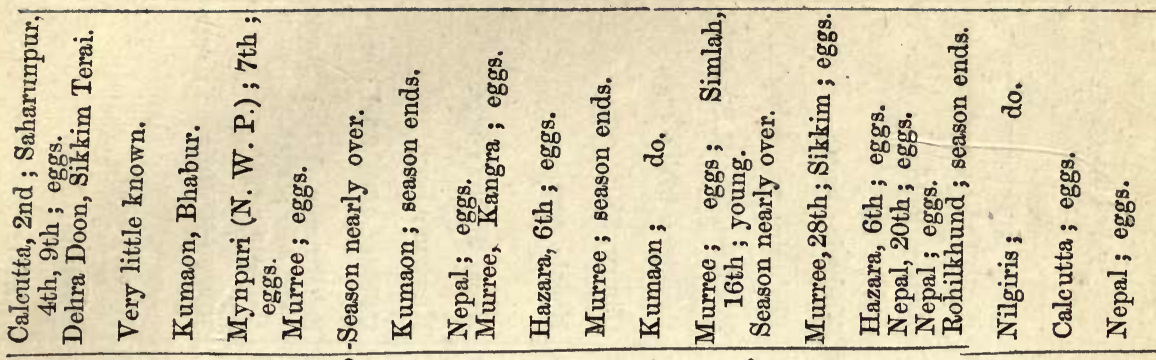

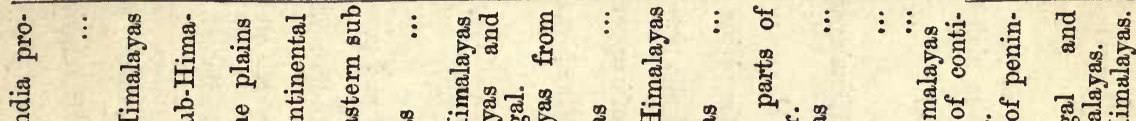

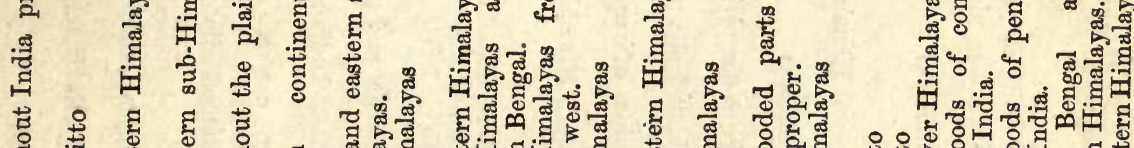

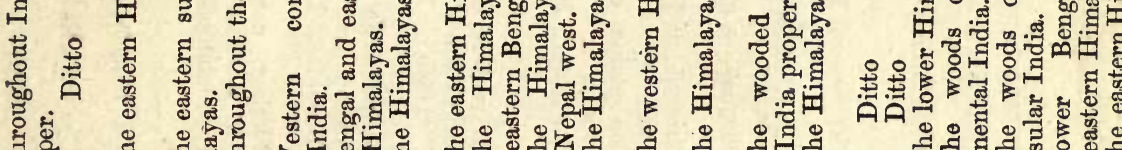

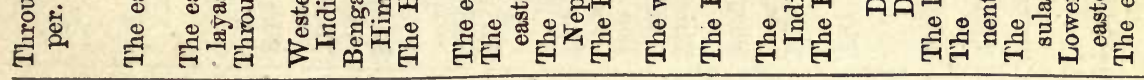

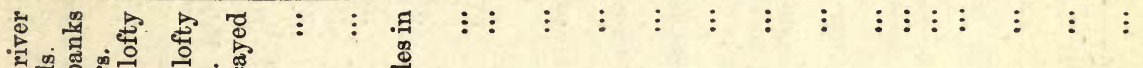

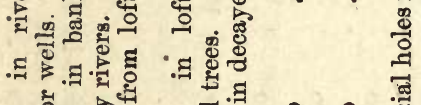

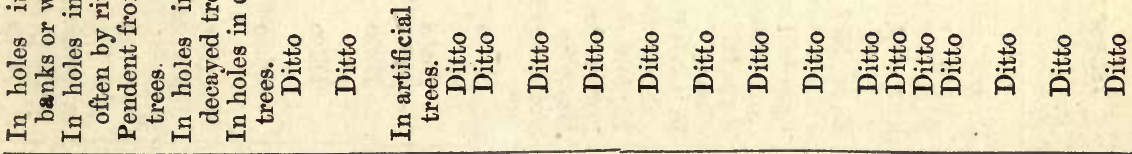

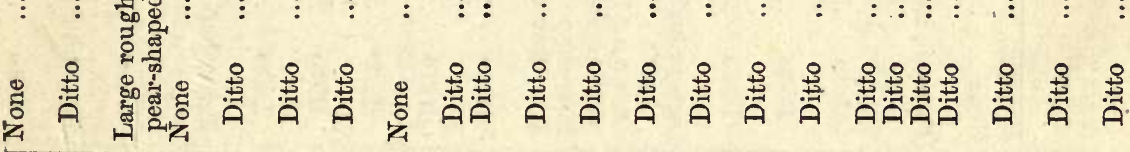

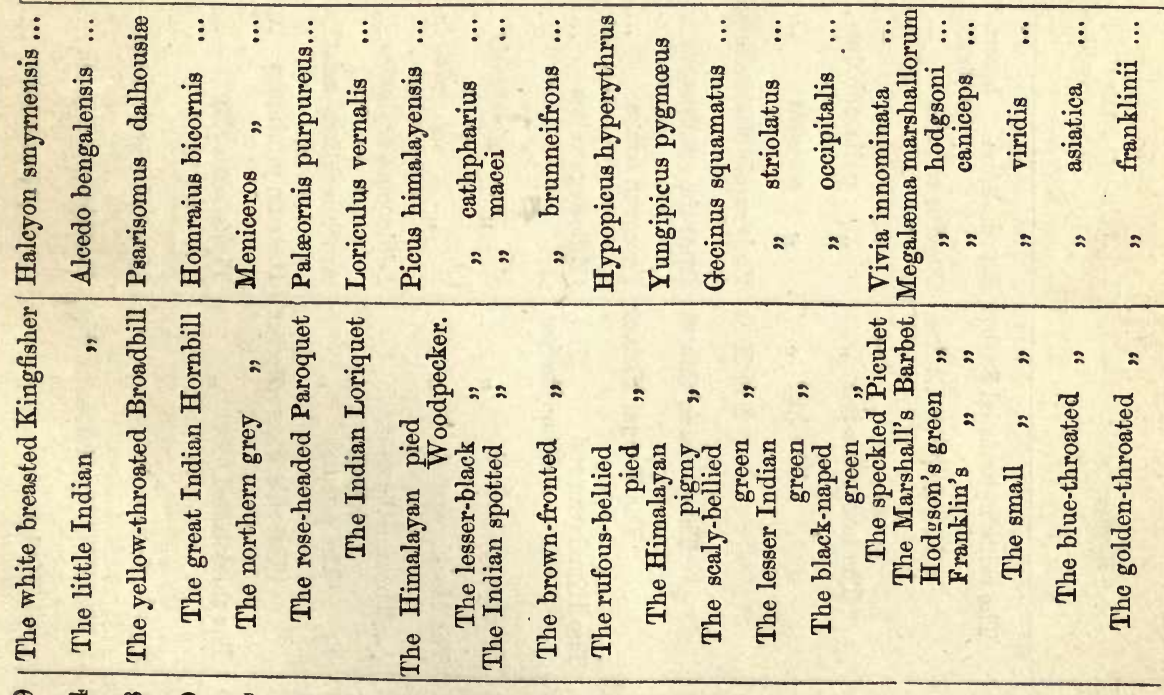

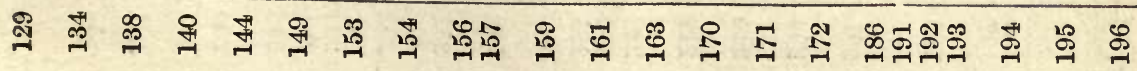




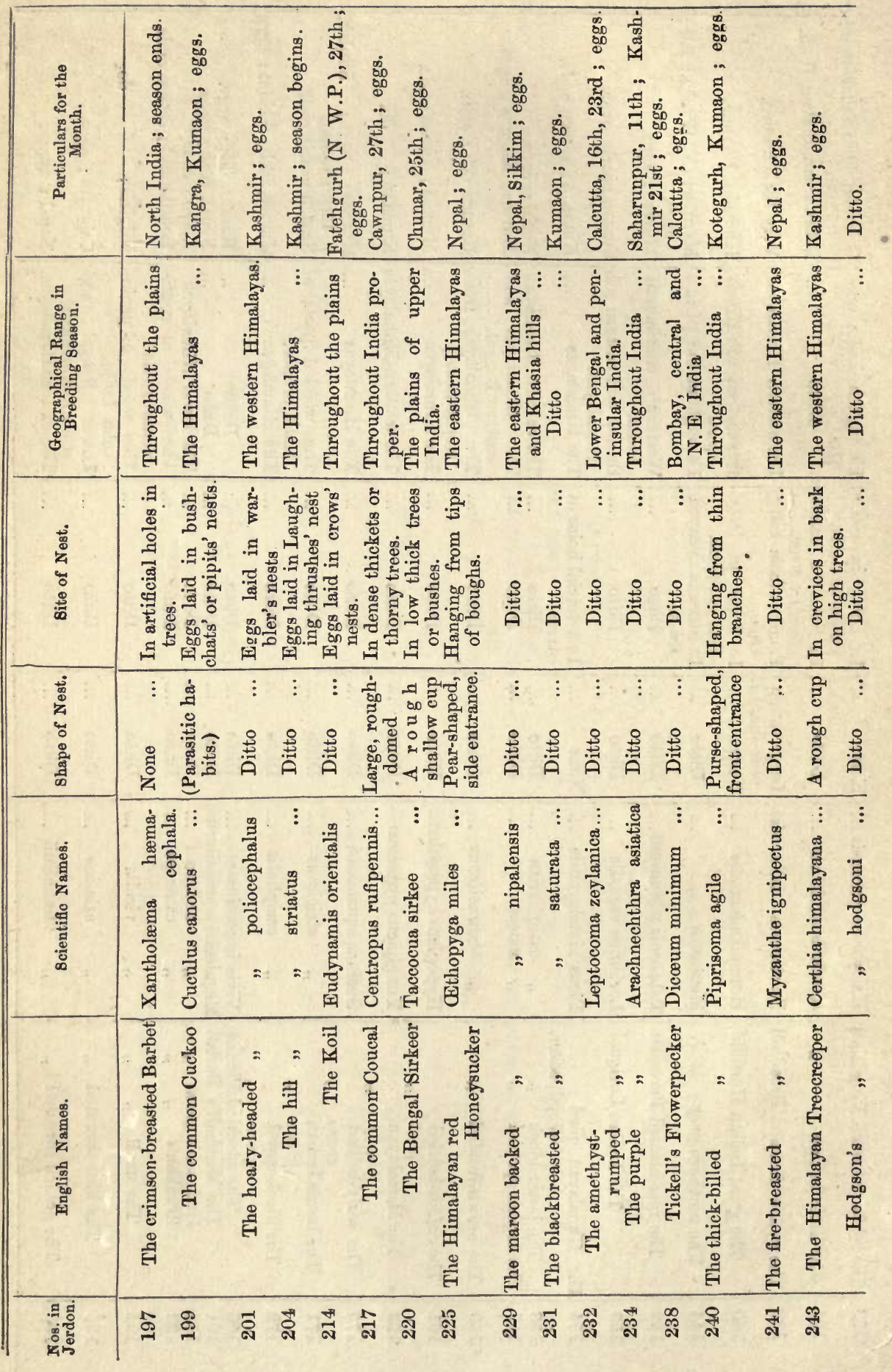




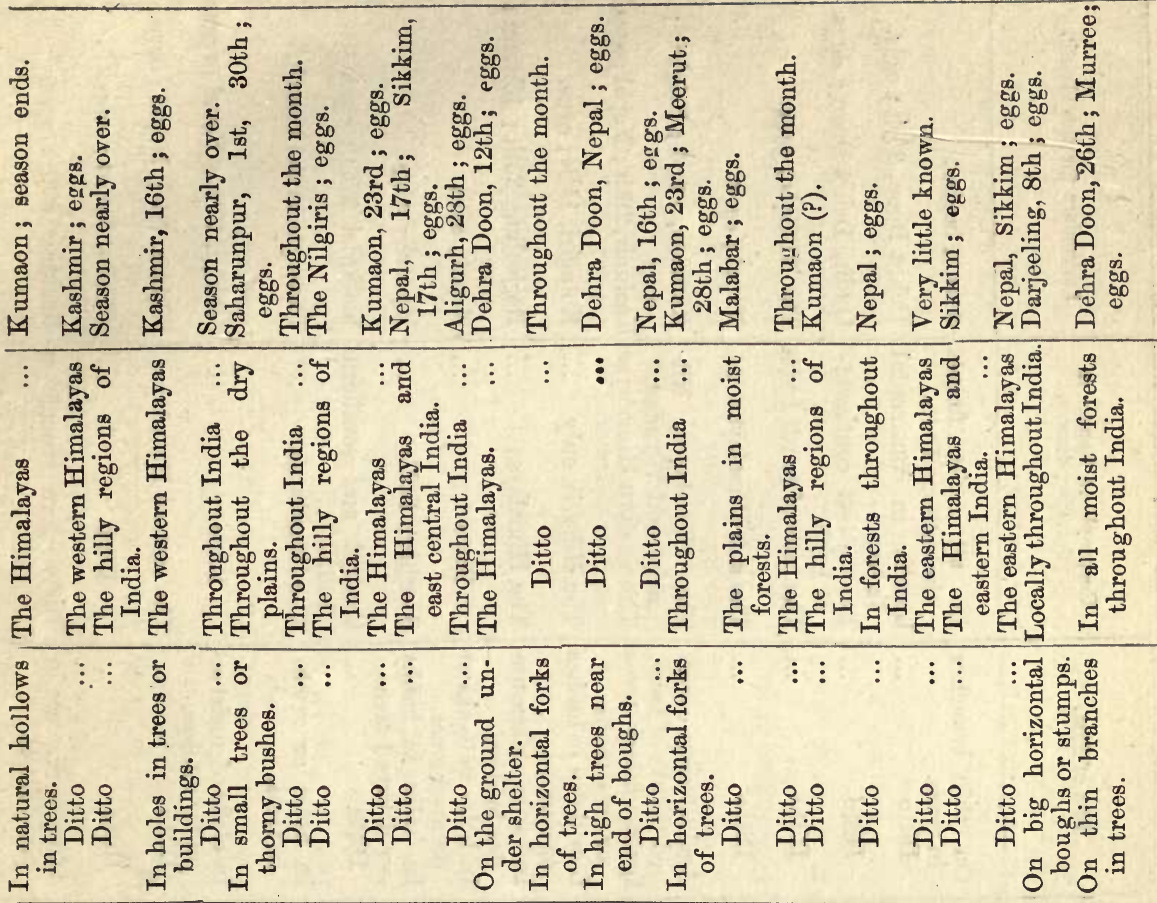

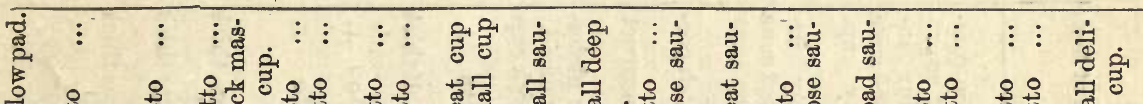

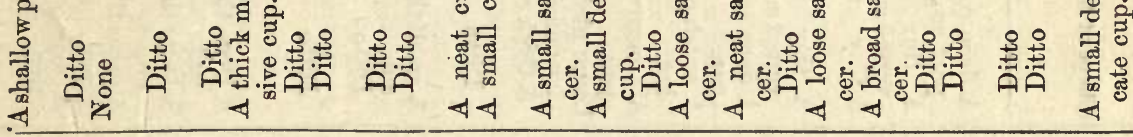

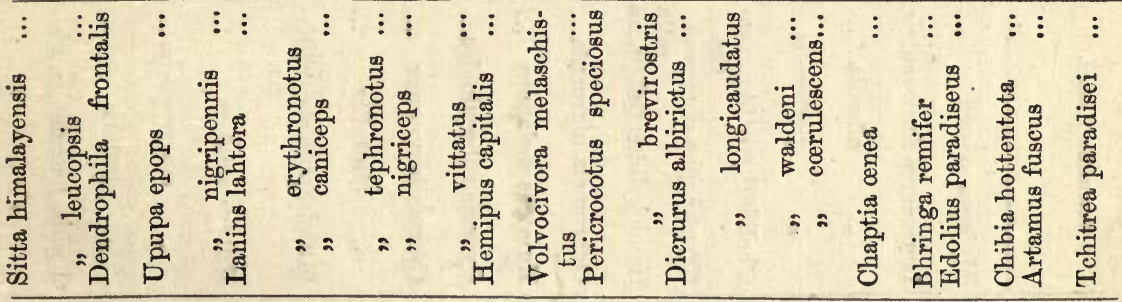

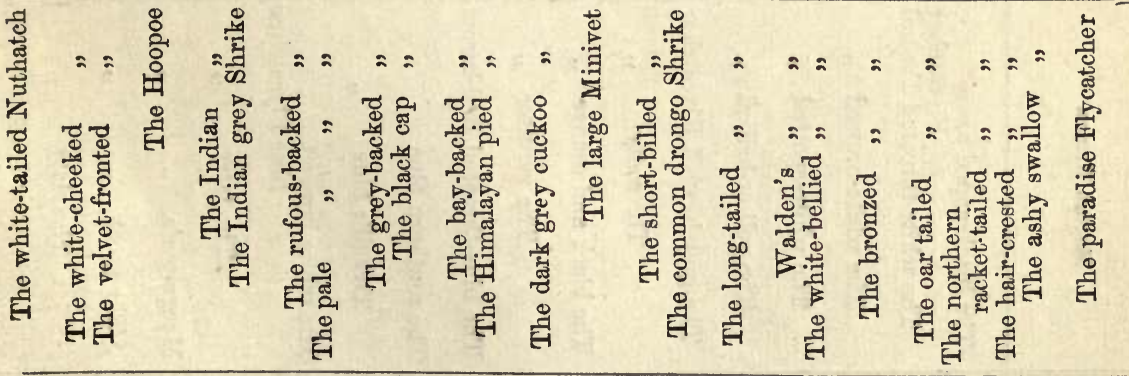

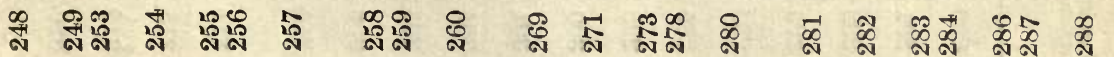




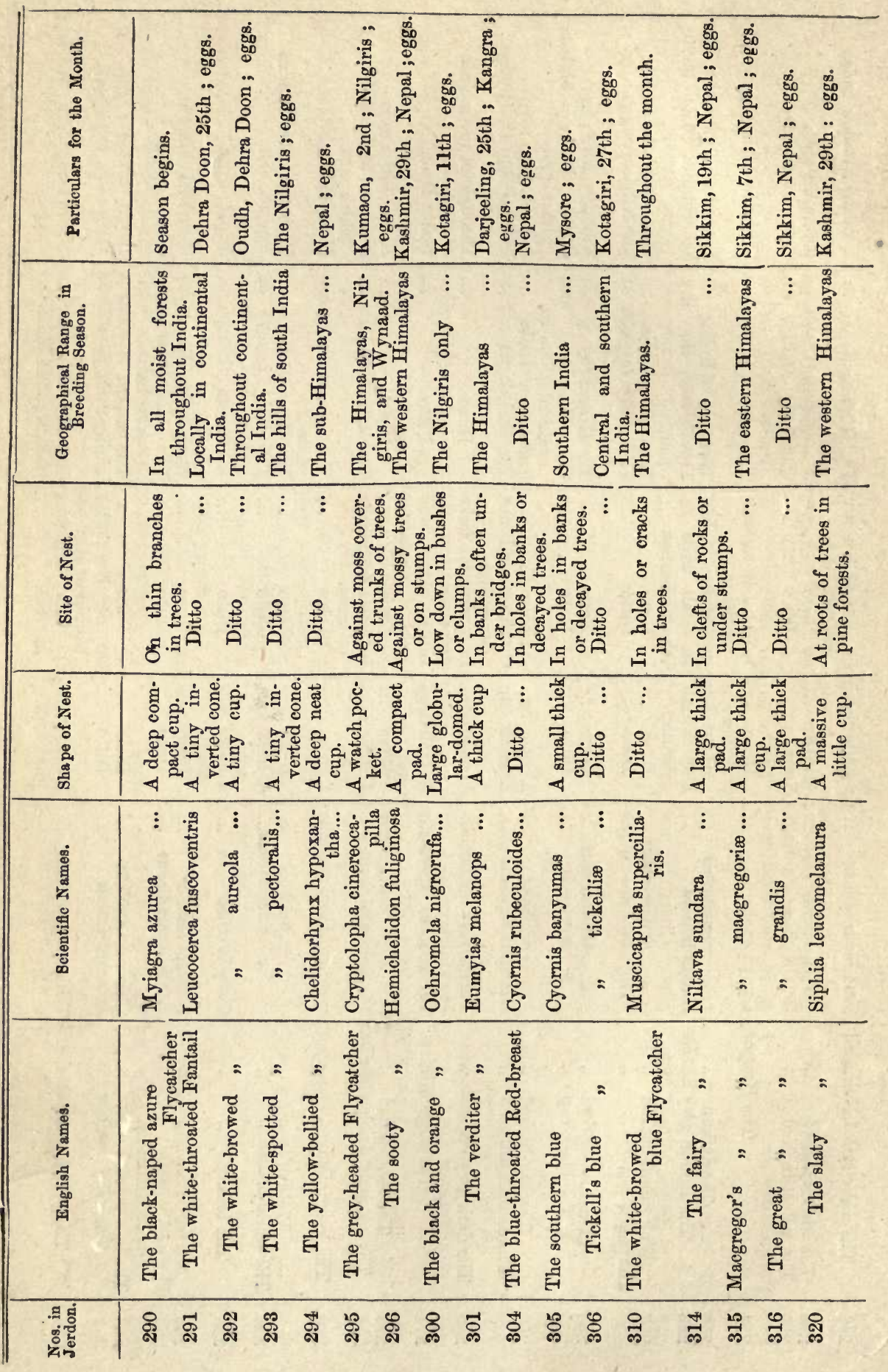




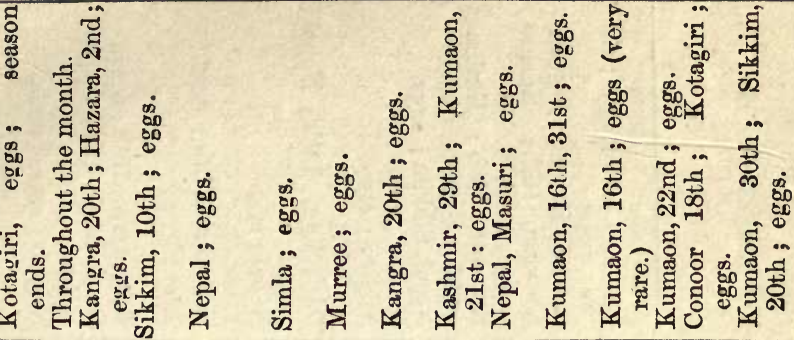

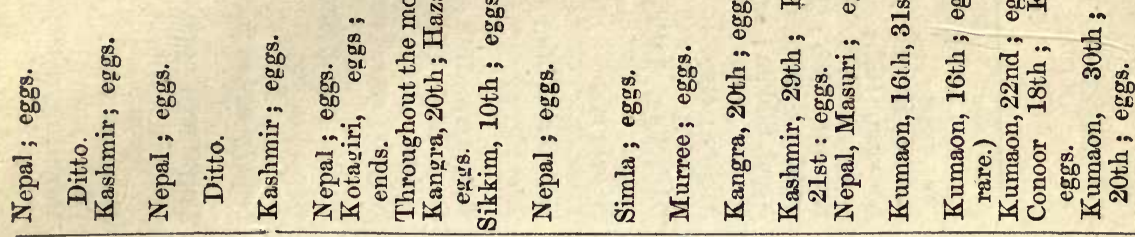

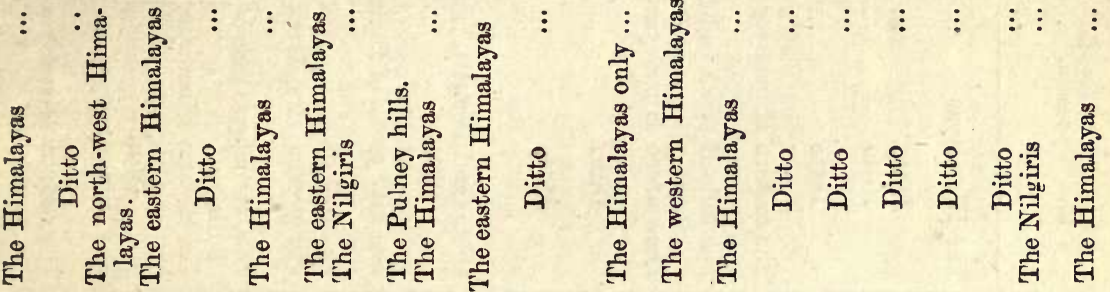

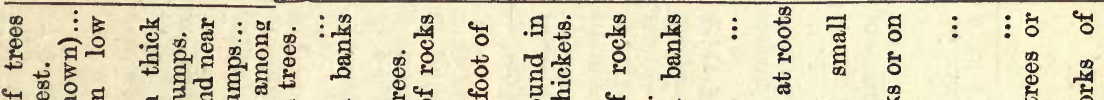

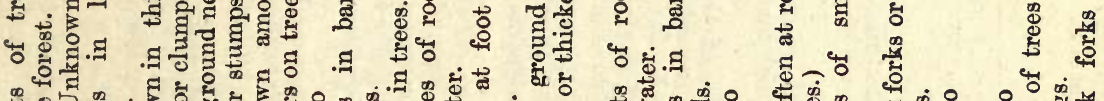

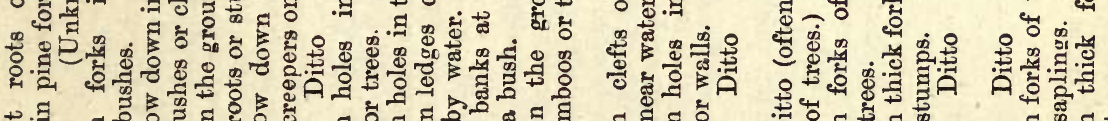

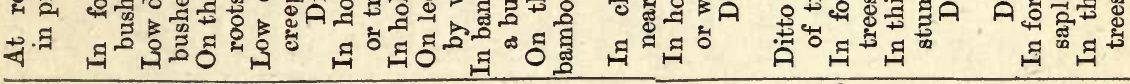

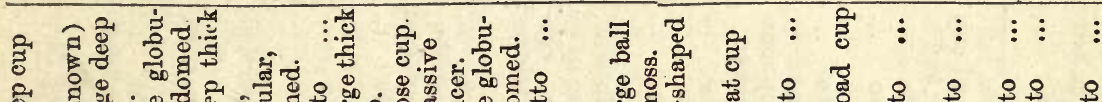
等

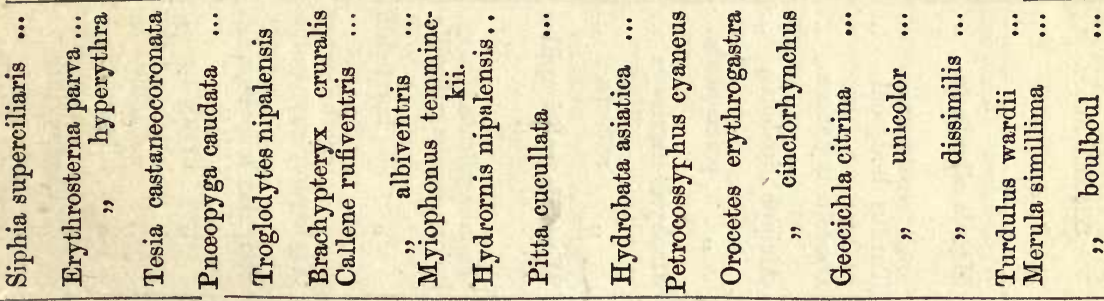

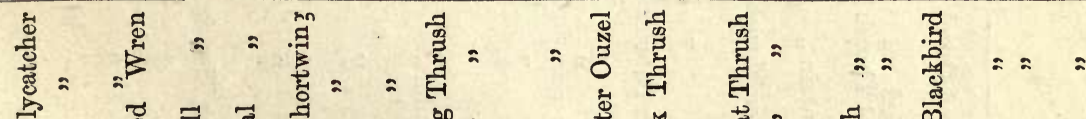

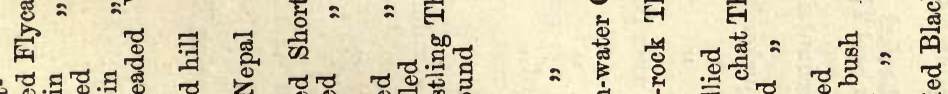

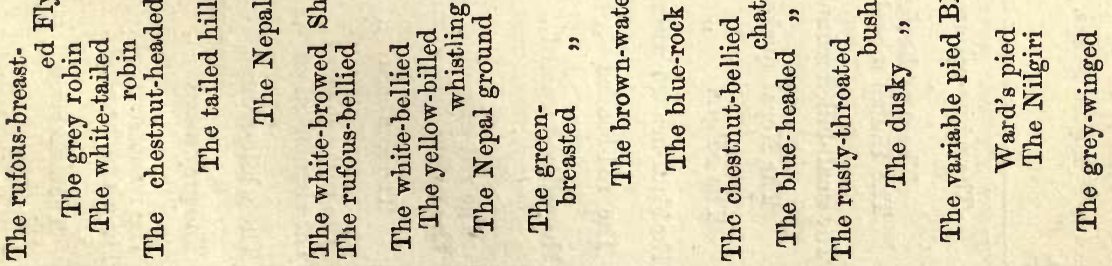

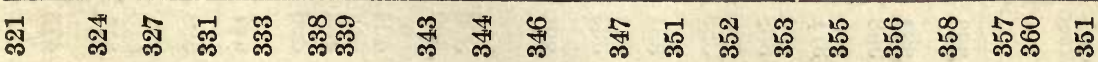




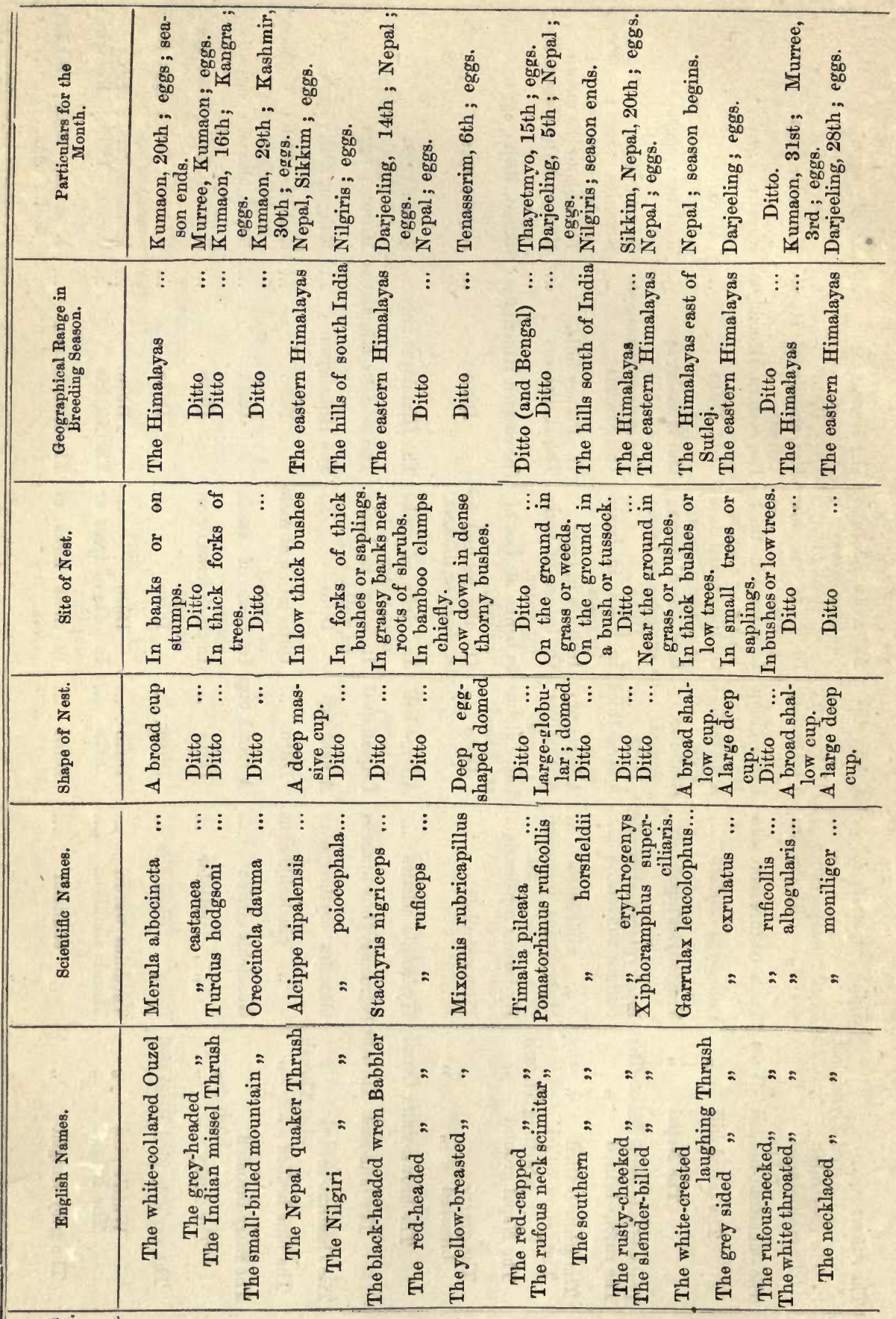

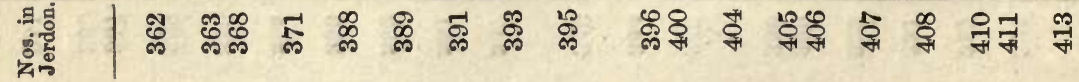




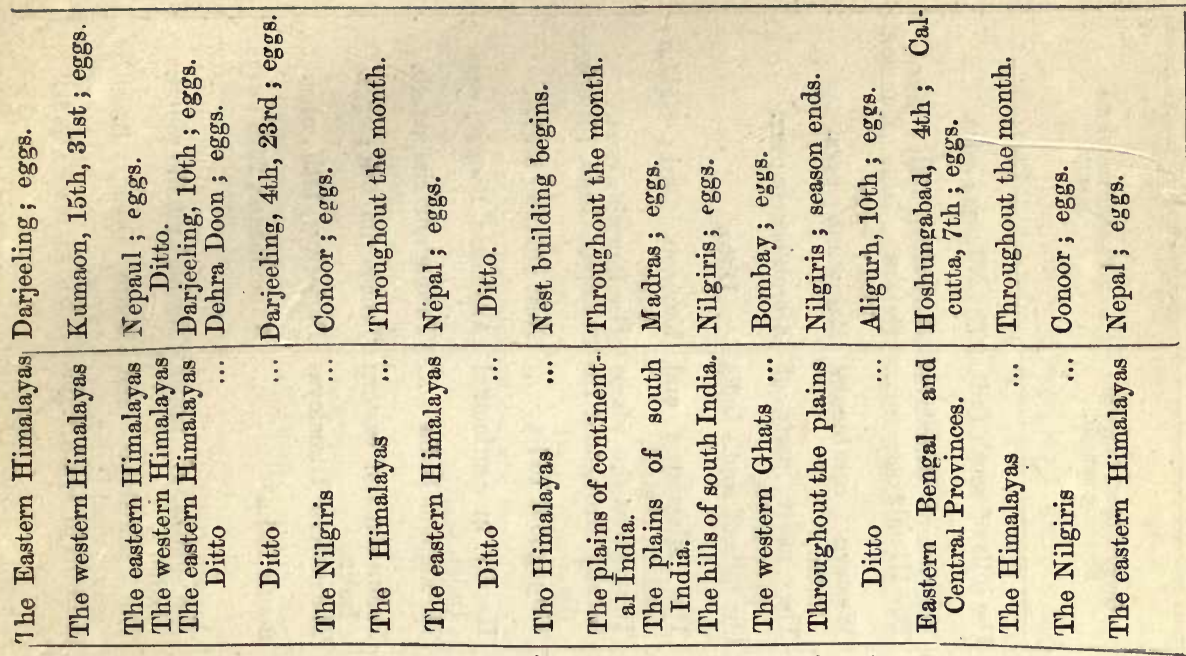

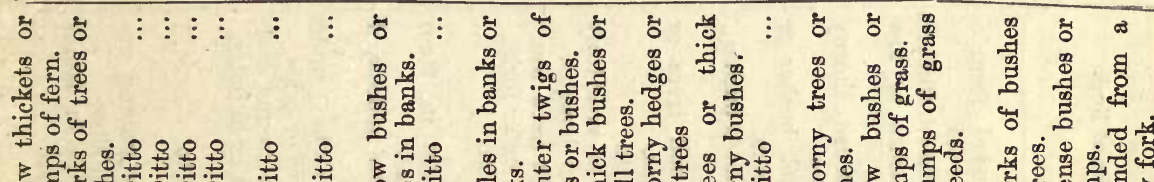

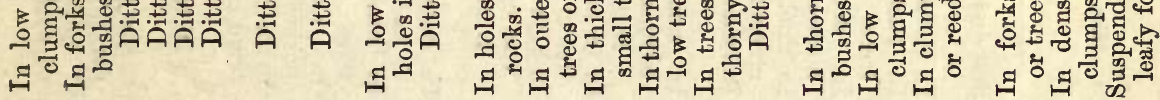

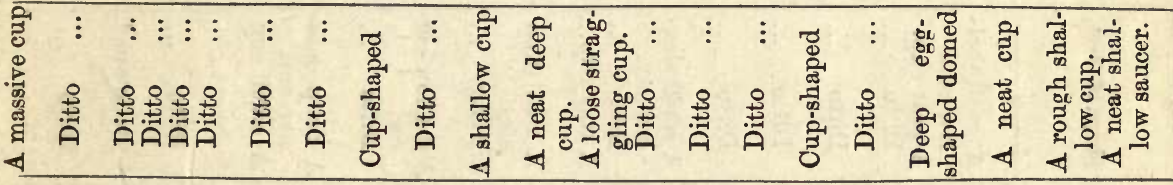

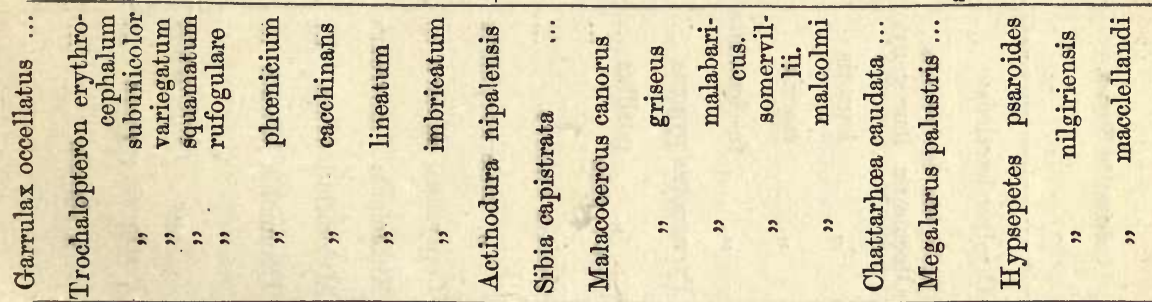
丞

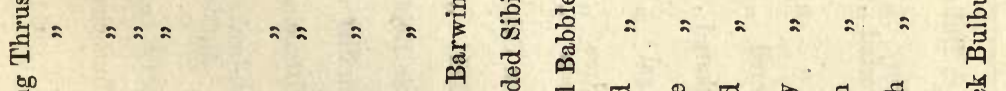

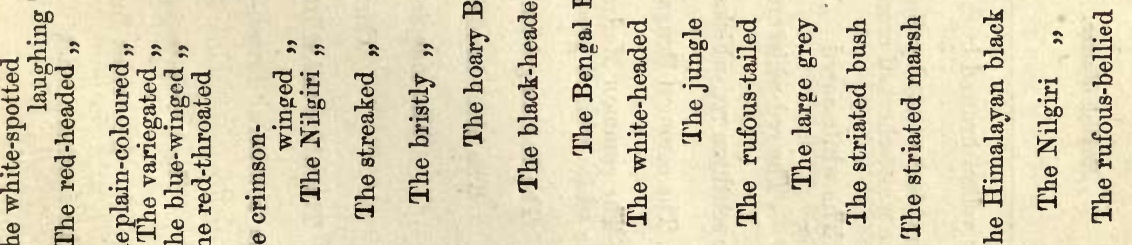

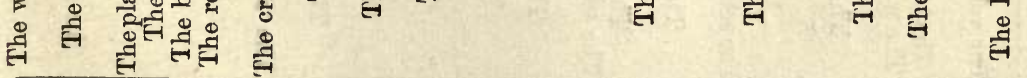

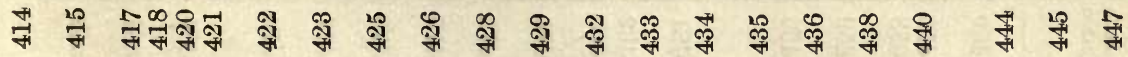




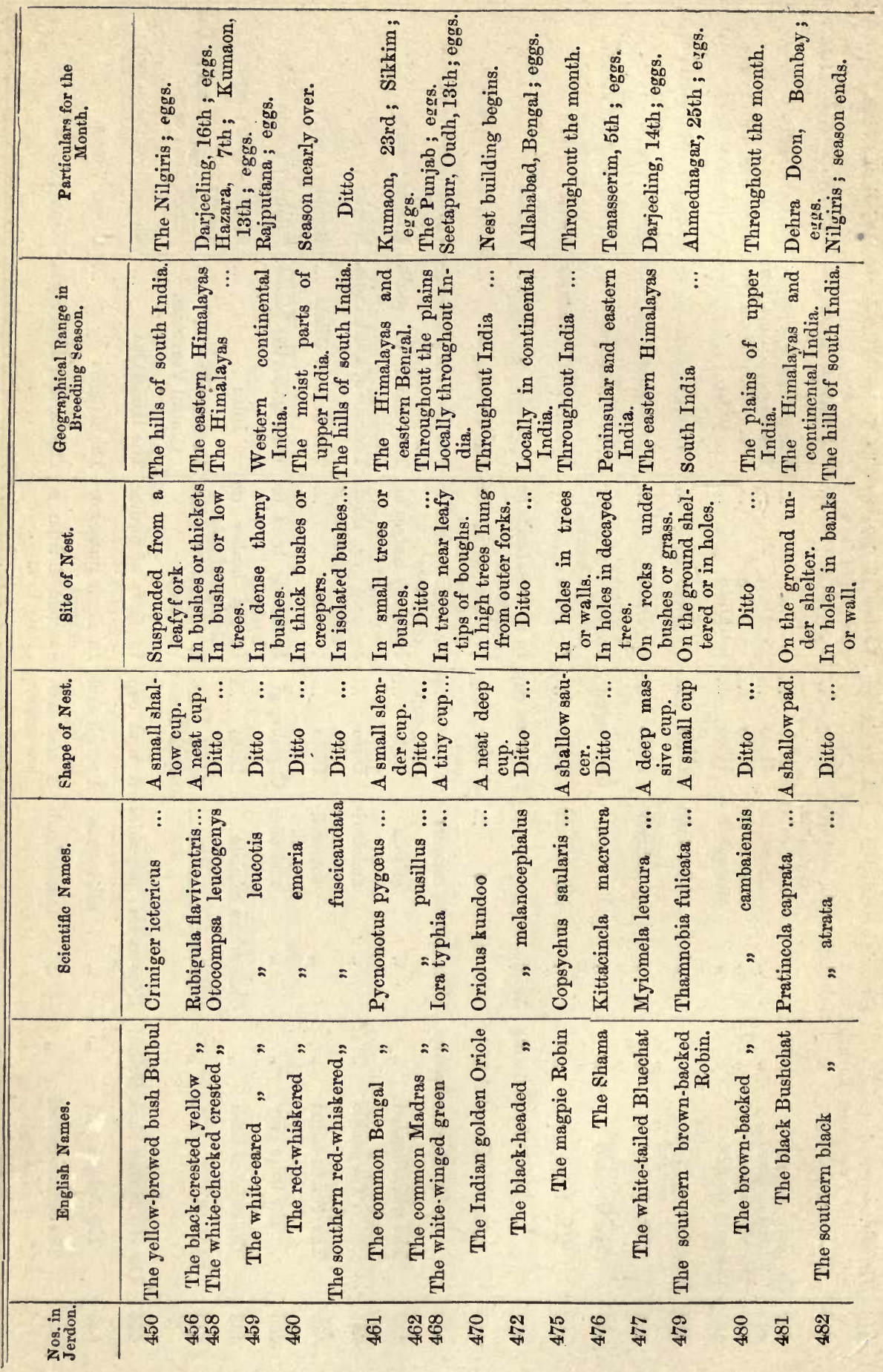




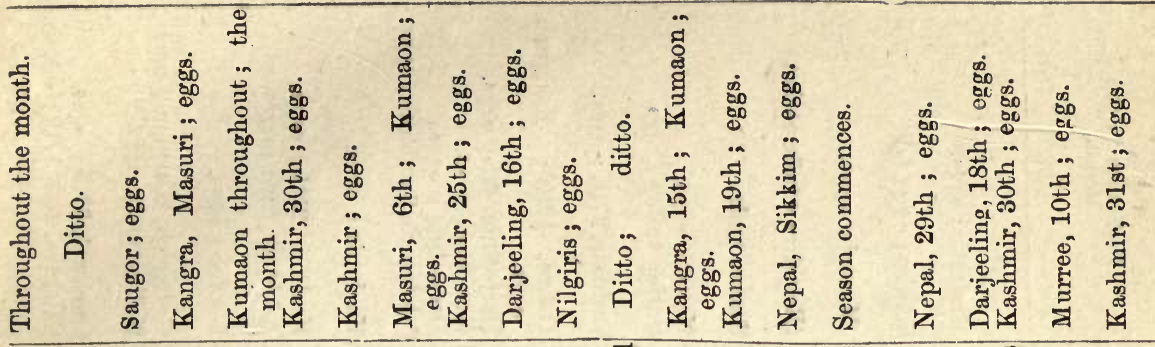

ॠ

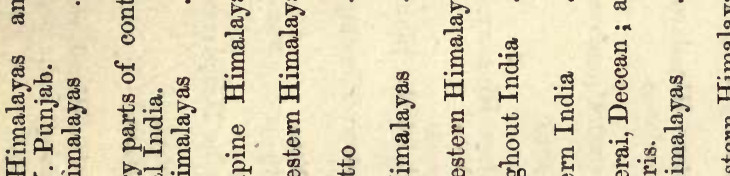

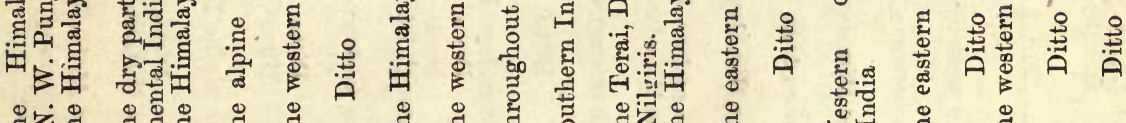

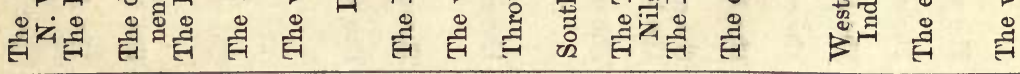

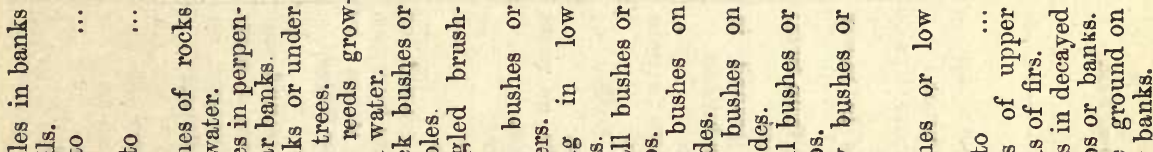

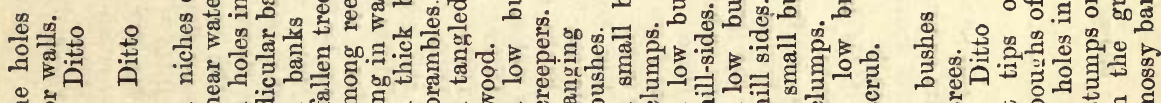
进定

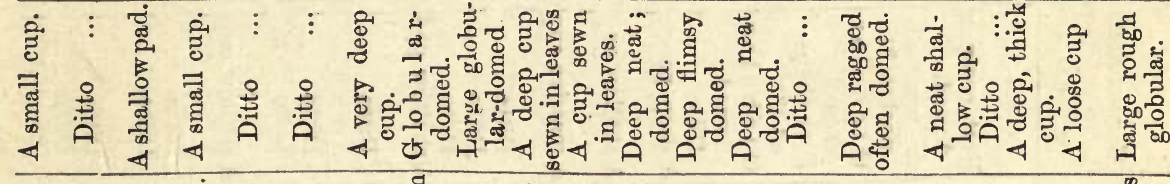

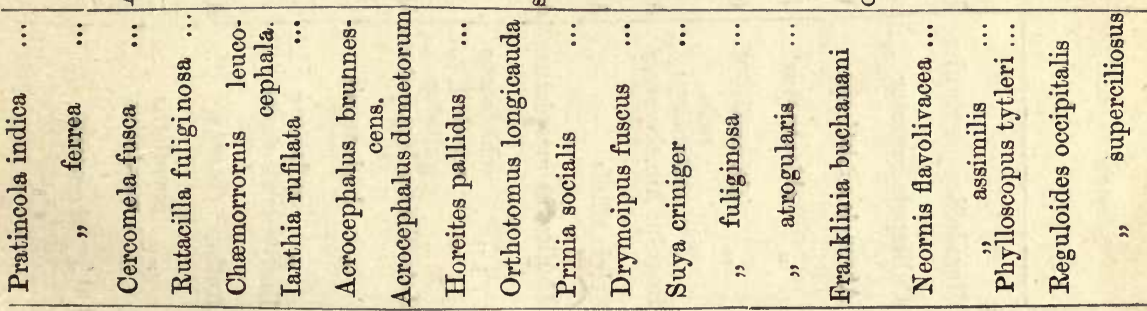

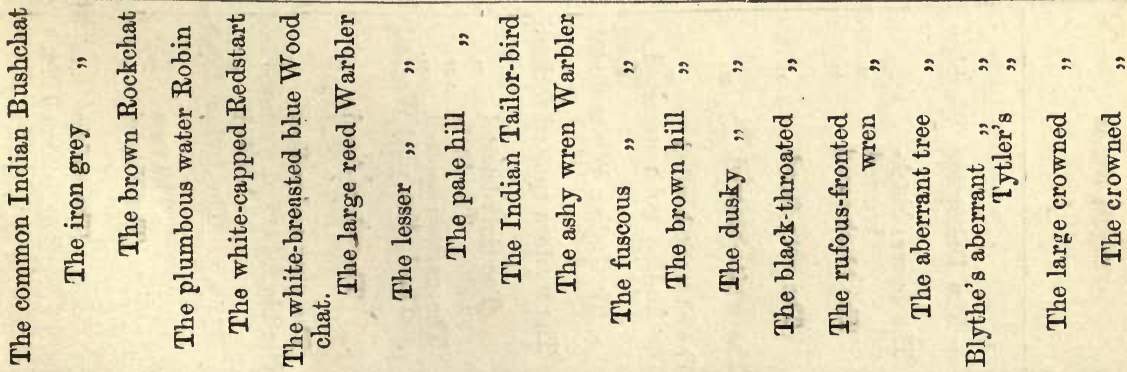

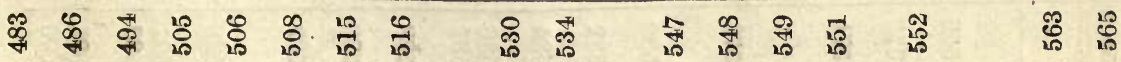




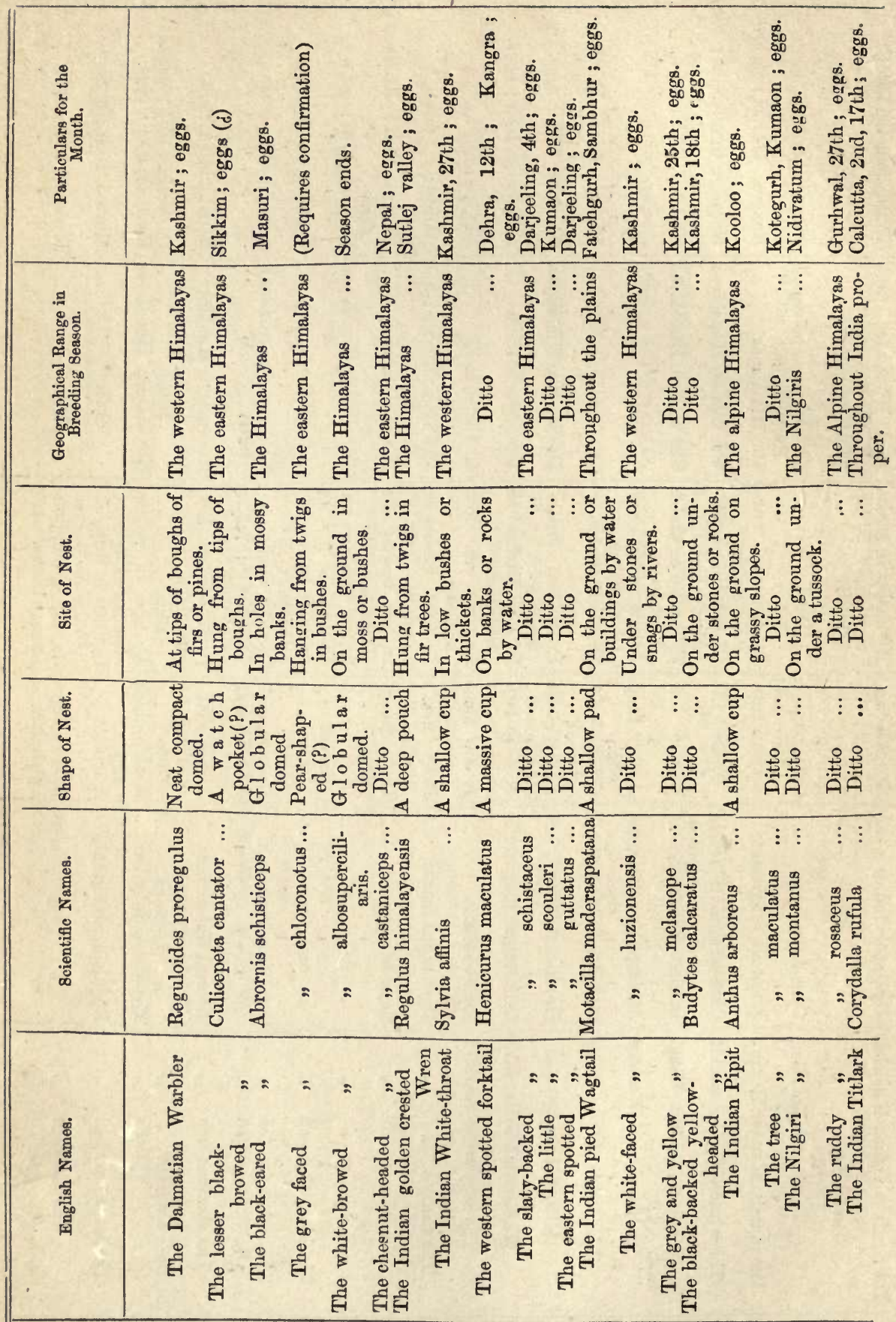

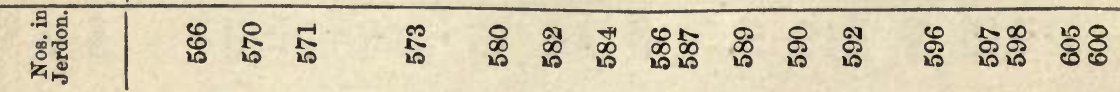




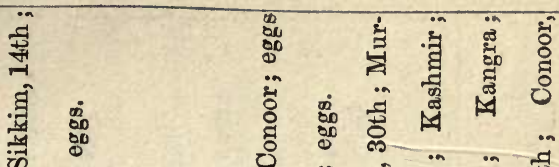

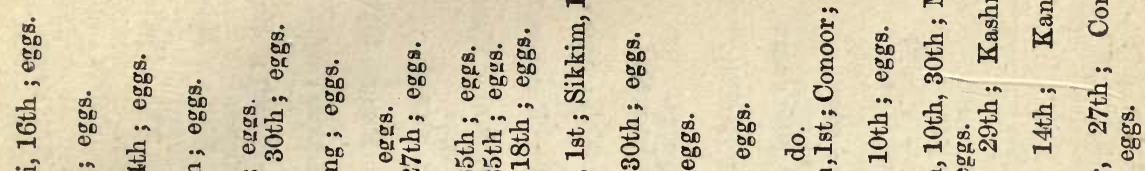

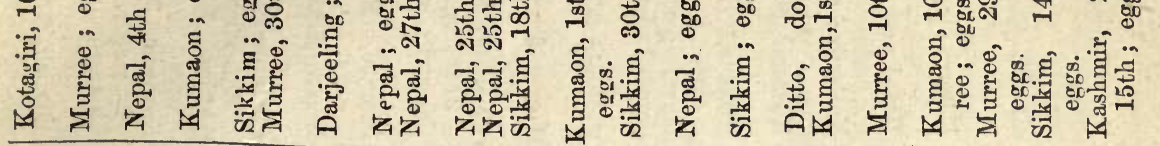

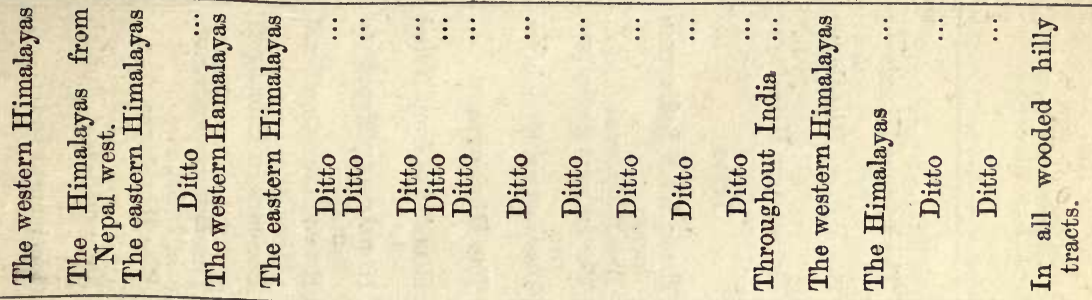

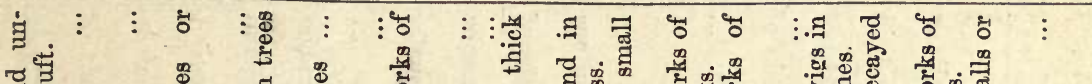

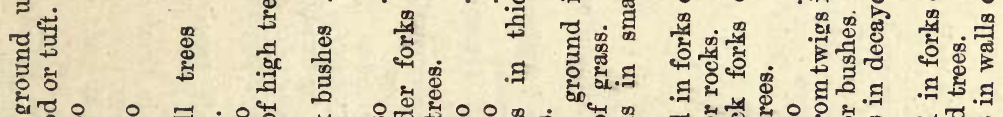

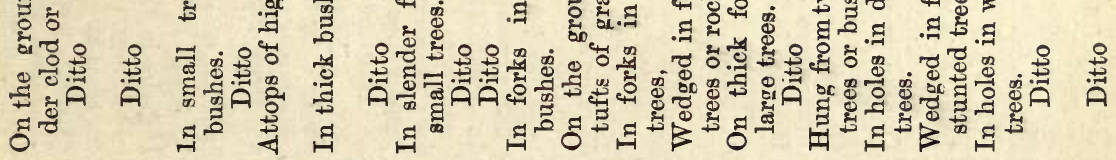

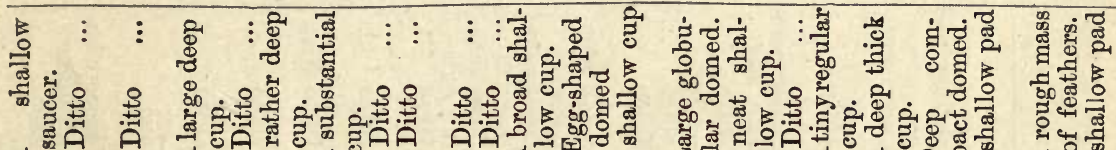
४

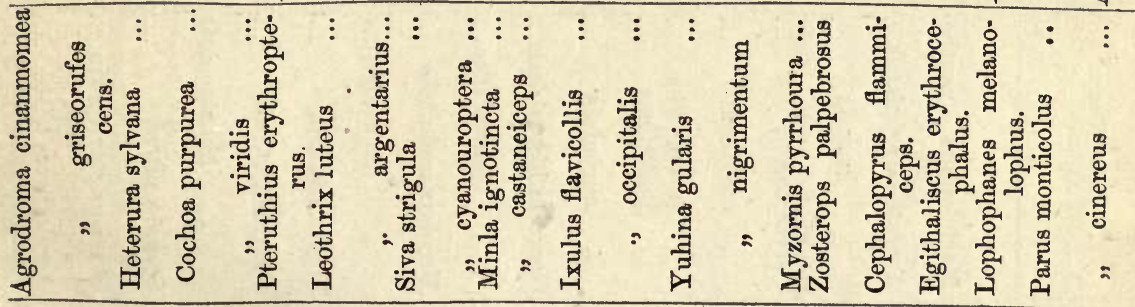

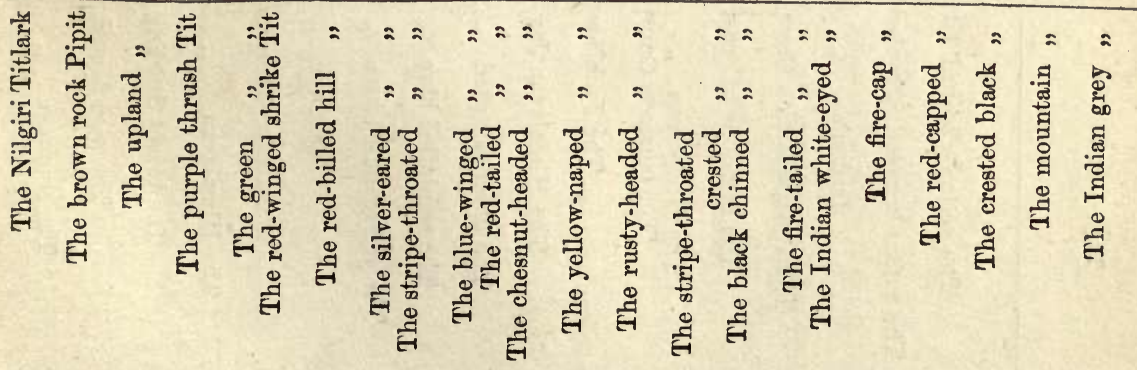

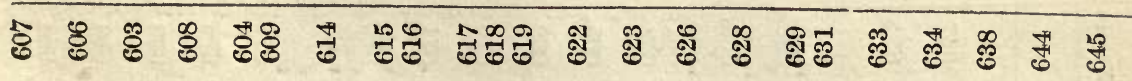


MAY.

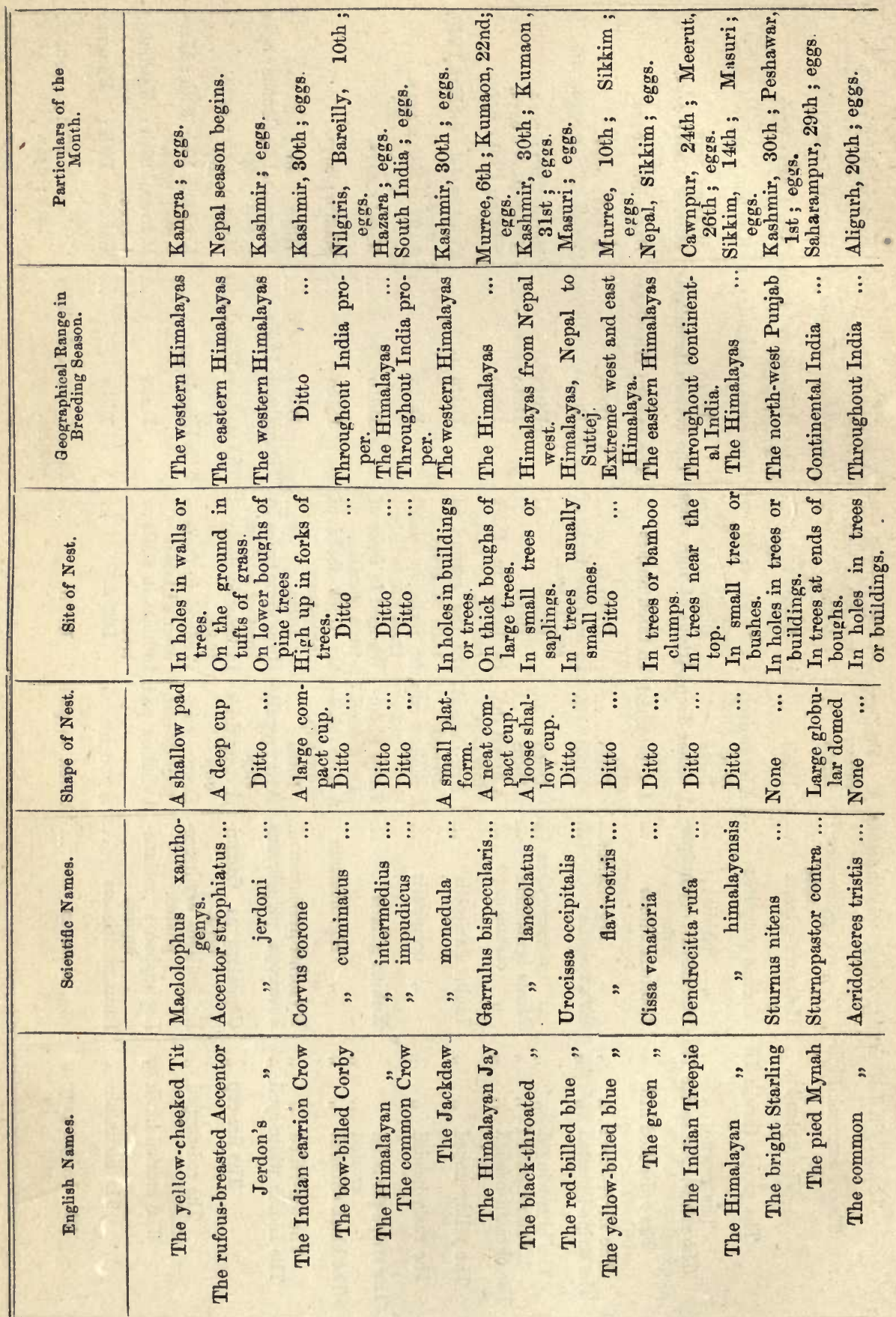

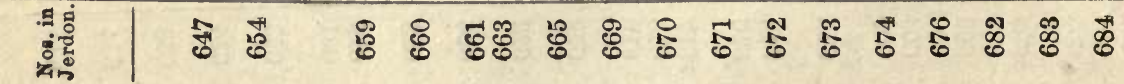




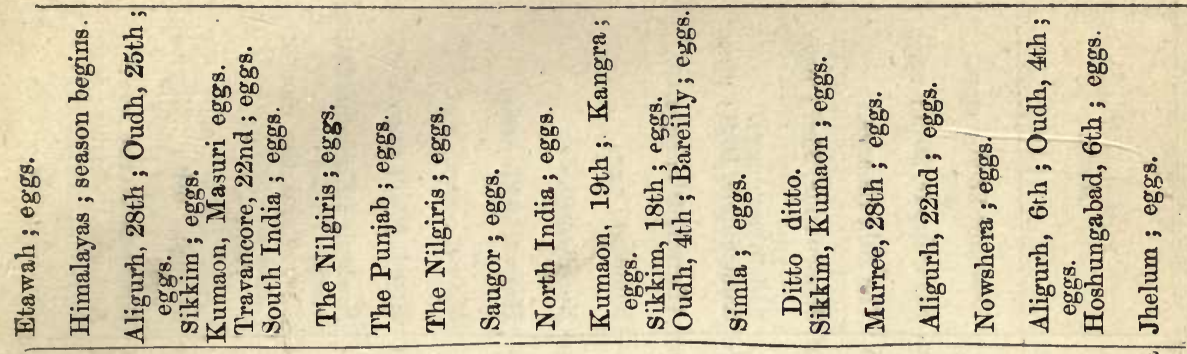

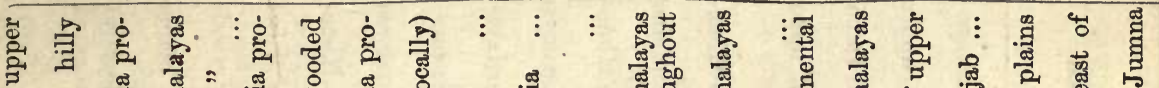

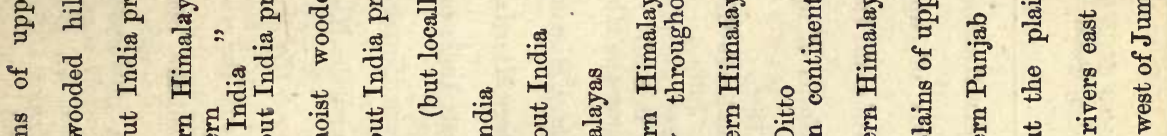

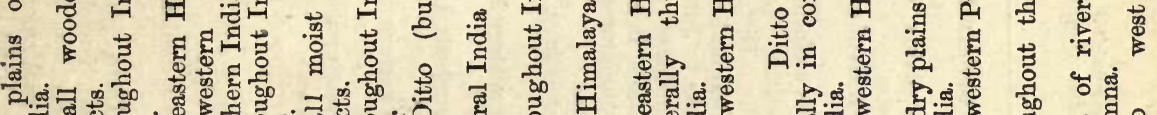

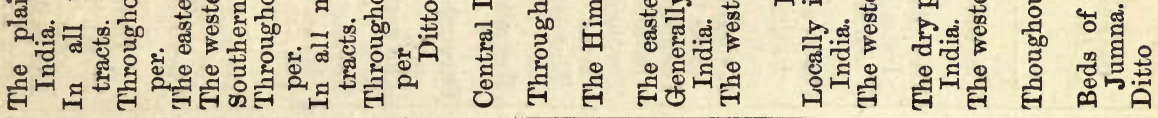

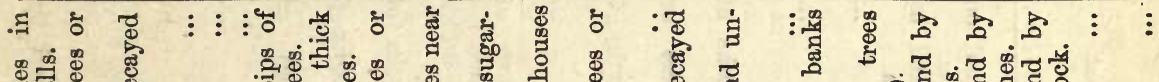

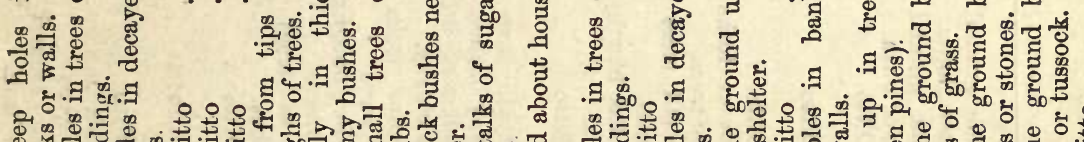

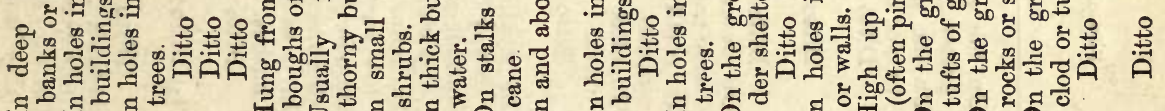

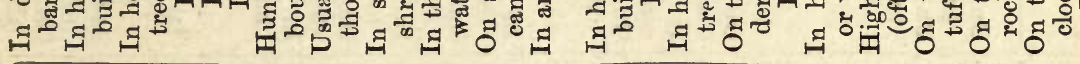

\begin{tabular}{|c|c|c|c|c|c|c|c|c|c|}
\hline : & $\vdots \quad \vdots$ & 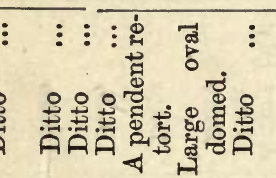 & $\begin{array}{l}\vdots \\
\vdots \\
\text { 赵 } \\
\text { A }\end{array}$ & 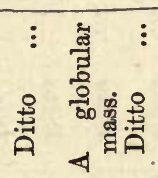 & 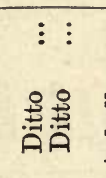 & 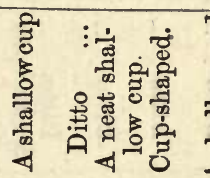 & 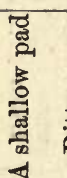 & & 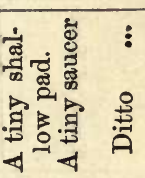 \\
\hline
\end{tabular}

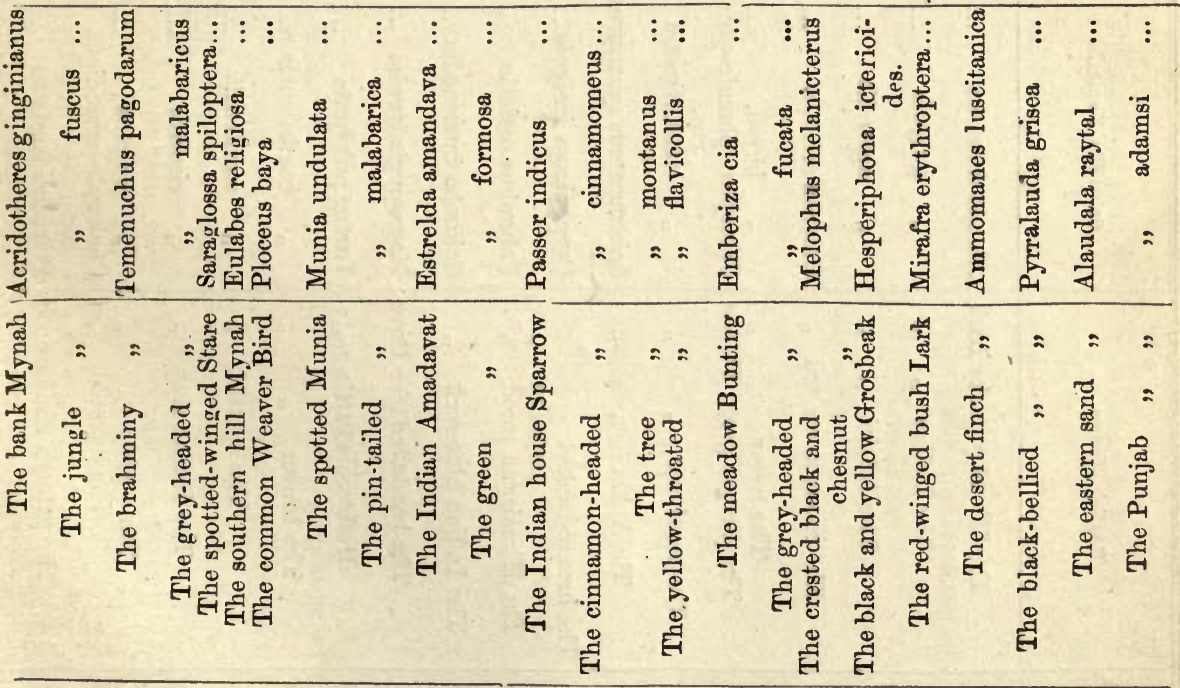

送㴪 


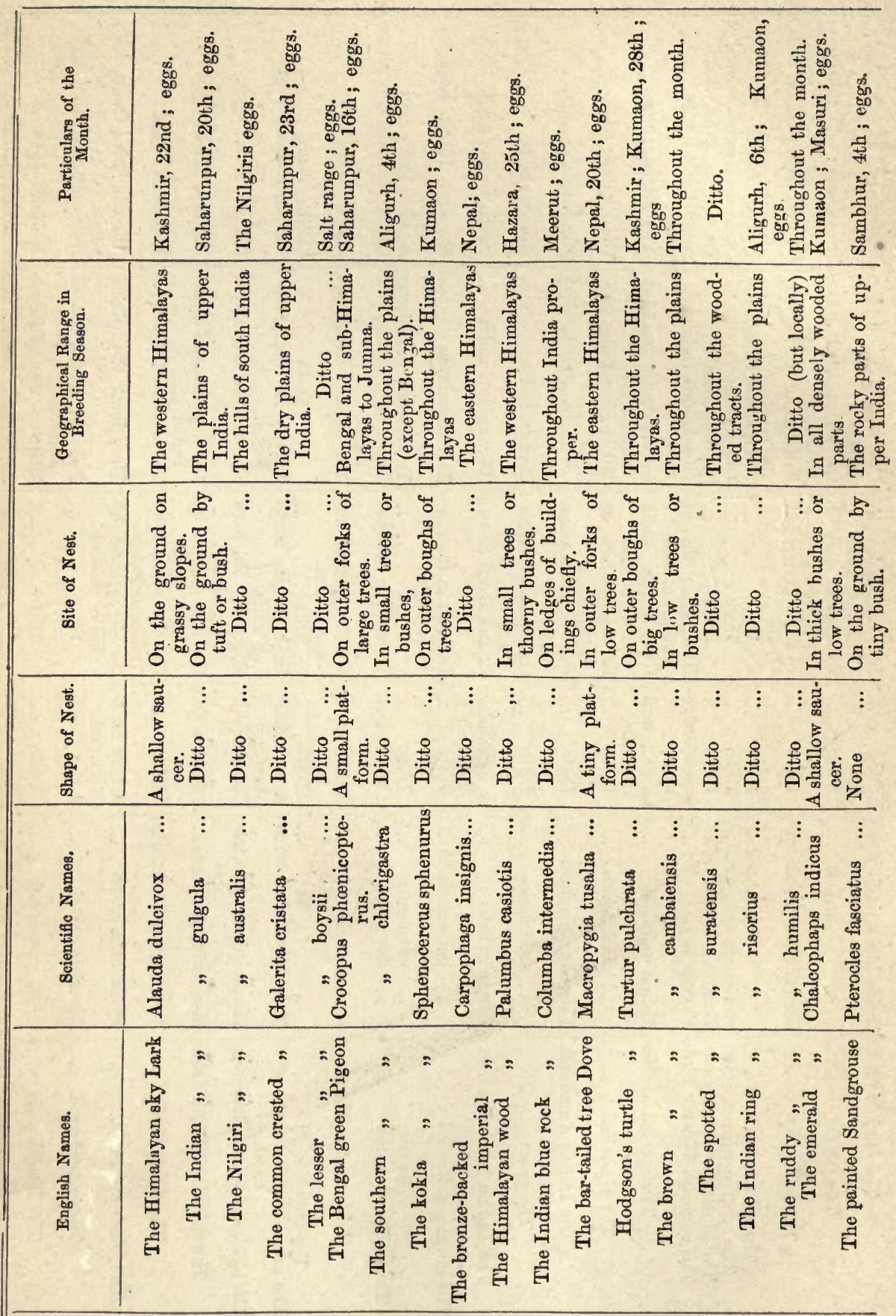

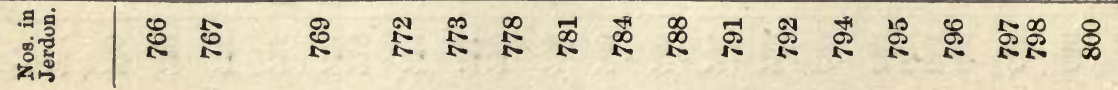




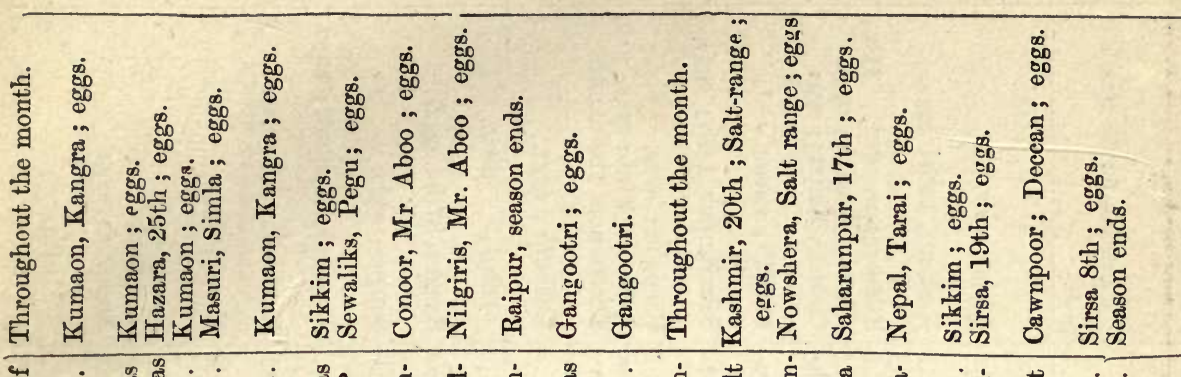

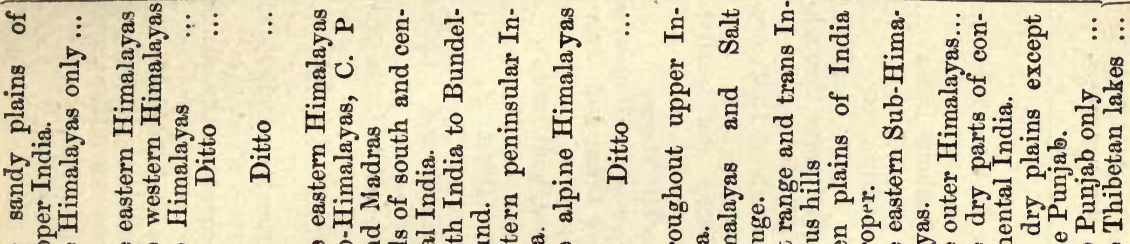

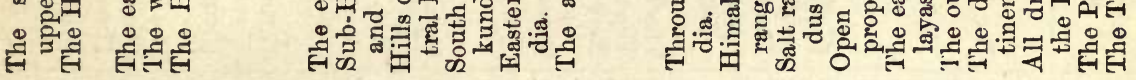

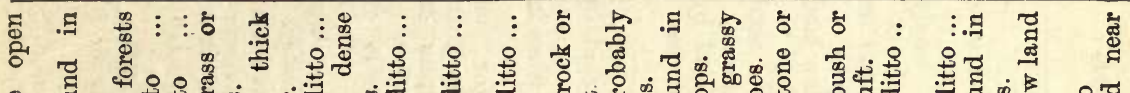

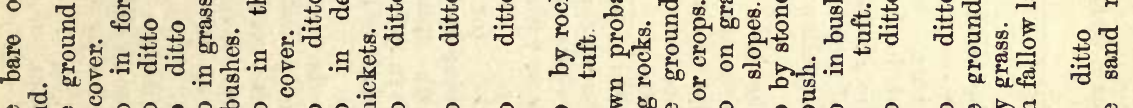
ई

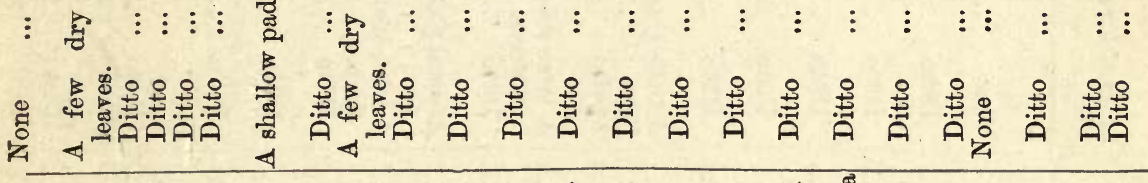

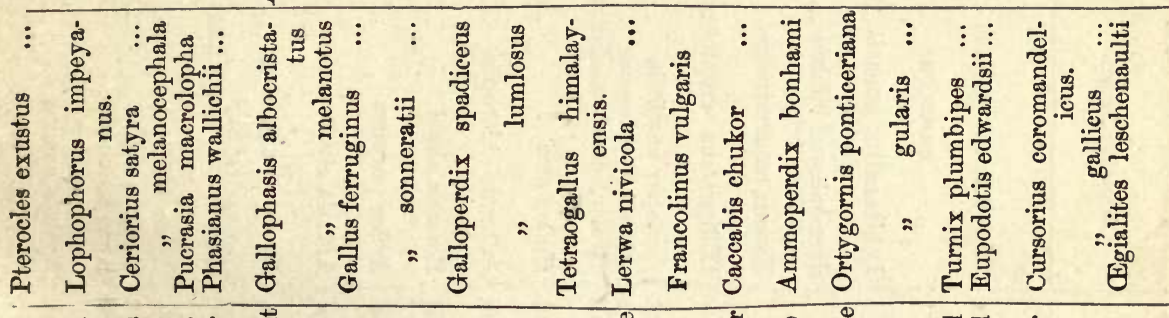

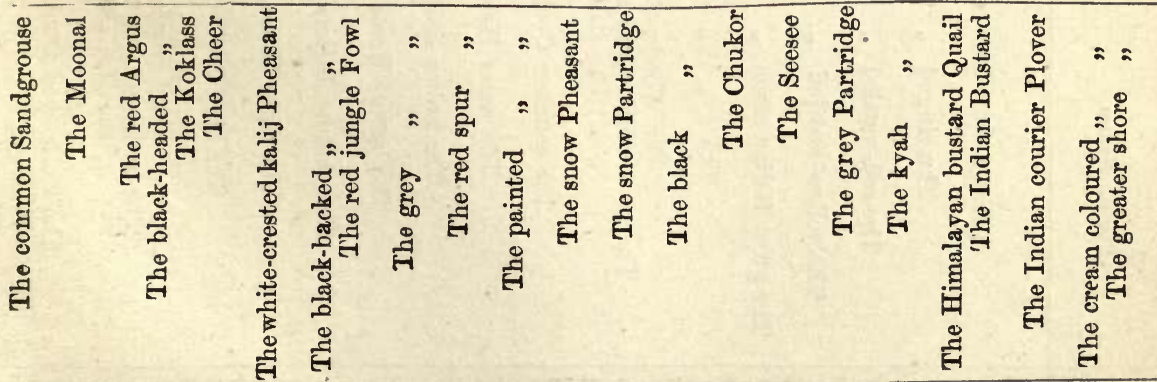

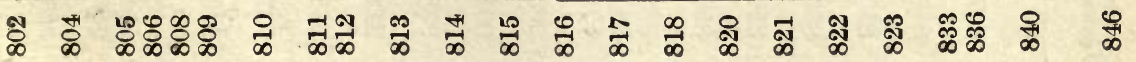




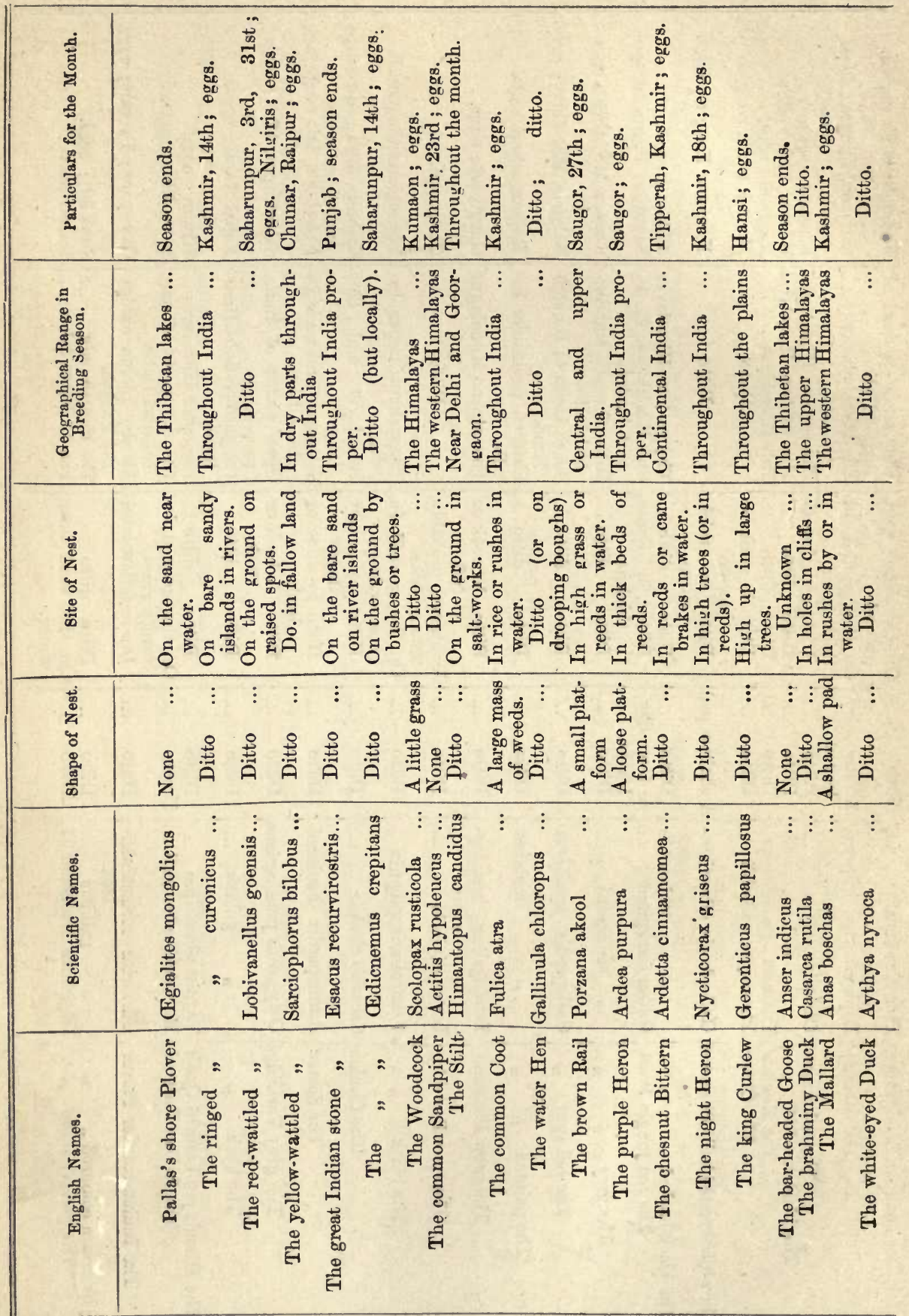

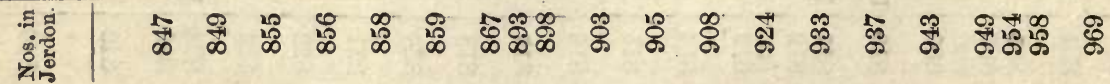




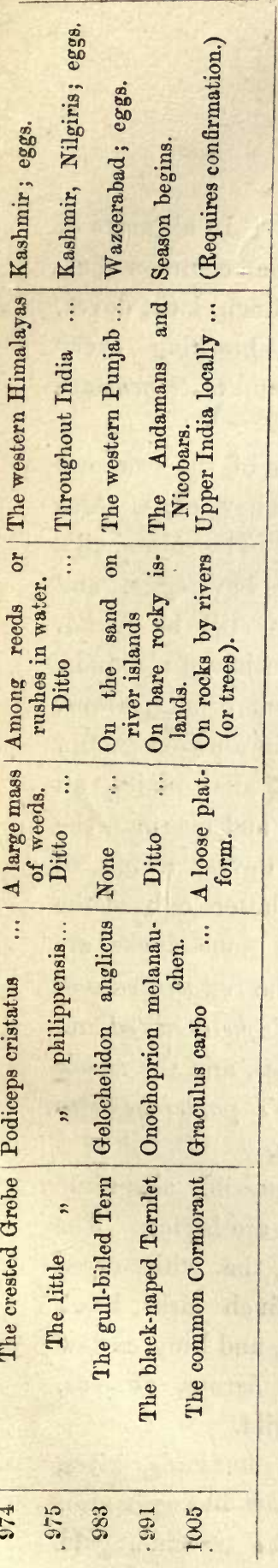




\section{JUNE.}

THE breeding season is now just past its height. In all parts of the country the shrikes, the paradise flycatcher, the common bulbuls, weaver birds and sparrows, the black-bellied finch lark, doves, the common sandgrouse, and the little grebe are breeding every where; and throughout the plains the purple coot and waterhens are pairing and building.

In the Himalayas, a few of the hawks and one of the swallows are still laying. The goatsuckers, bee eater, and roller all have eggs. Also the little kingfishers and broadbills in the low valleys. The Marshall's barbet begins to lay. All the cuckoos and honeysuckers have eggs, and in the far west nuthatches' and tree creepers' eggs may still be found. Most of the minivets, drongos, flycatchers, wrens, thrushes of all kinds, blackbirds, most of the babblers, laughing thrushes, bulbuls, orioles, robins, chats, reed warblers, hill warblers, tree warblers (except the abrornis group, which are early breeders), white throats, forktails, wagtails, pipits, all the bill tits (Leiotrichina), the carrion crow, the jays and magpies, the mynahs, munias, sparrows, buntings, skylark, pigeons, doves, a few of the pheasants, partridges, grouse and quail (these latter only at the higher elevations), sandpipers, coots, rails, bittern, and some ducks are laying throughout the month. Towards the end of it the red-wingea wall creeper, striated jay thrush, white-throated bulbul, fulvous-breasted and large hill warblers, tree sparrows, most of the finches, and the ruddy rail are pairing and building. The "sacfa" or Hodgson's partridge also pairs at the end of this month, in the alpine Himalayas.

In the Punjab, the crested honey buzzard, and possibly also some of the eagles and kites have eggs. All the bee eaters are laying. The roller, white-breasted kingfisher, koel, concal, sirkeer, the white-eared bulbul, golden oriole, treepie, mynahs, bush larks, finch larks, black partridge, bustard, plovers, stilts, white-necked storks, and king curlew are all breeding. While the egrets, pond herons, cattle herons, bitterns, night herons, and spoonbills are beginning to pair and build.

In the North-West Provinces, the true eagles, buzzards, kites, and screech owl; are still breeding. The mosque swallow has eggs also. The goatsuckers and rollers, the little kingfisher, the common gold 


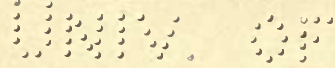

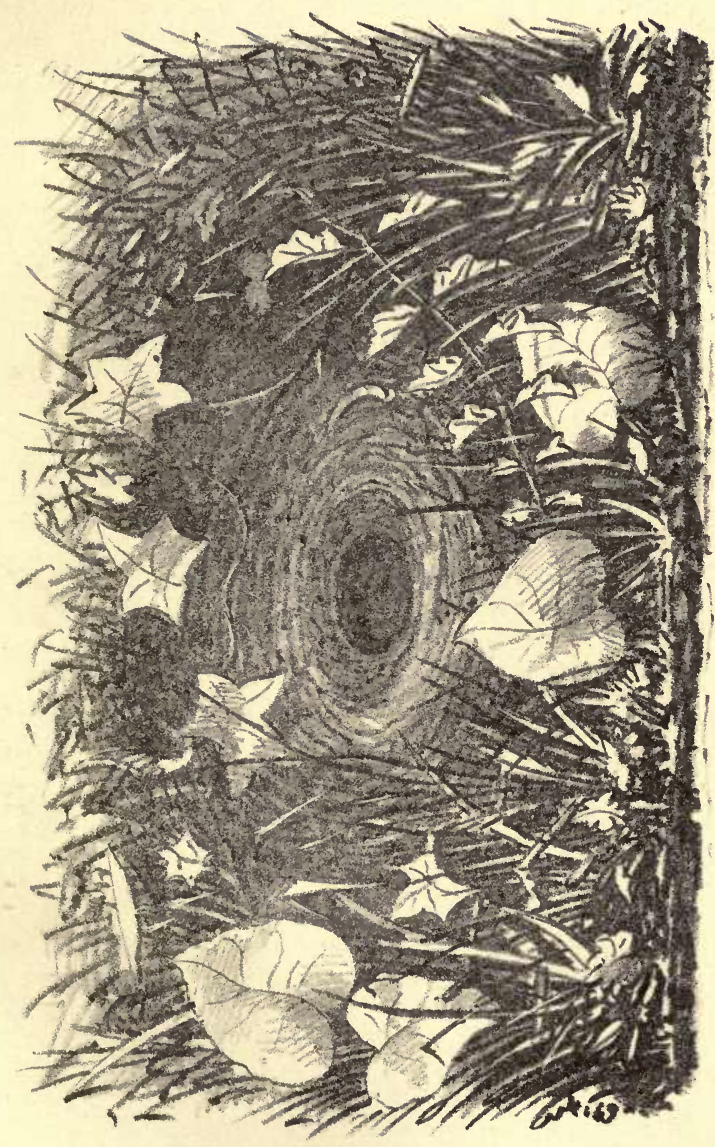

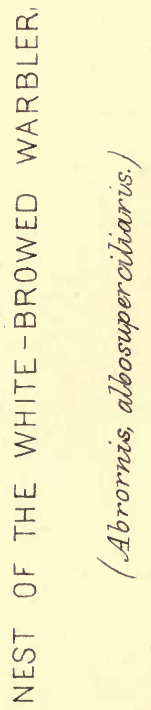


$\because \because \because \because \vdots \vdots \vdots \vdots$

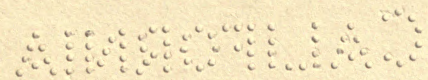


back woodpecker (second brood), the koel and concal, the purple honeysucker, the drongo shrike, white-browed fantail, yellow-eyed babbler, rufous-bellied wren babbler, the Bengal and large grey babblers, the bulbuls, and orioles are breeding. Eggs of the brown-backed robin may still be found. Stewart's wren warbler has begun to lay, so has the earth brown wren warbler and the Indian white-eyed tit and the common crow. The treepie, mynahs, black and chestnut bunting, bush larks, green pigeons, partridges, plovers, white-necked storks, shell ibis, white ibis, black-backed geese, and whistling teal all have eggs during the month. While towards the end of it the grey-capped wren warbler, pheasanttailed jacana, egrets, pond herons, cattle herons, some hitterns, night herons, spoonbills, cotton teal, and snake birds commence to pair and build.

In Bengal, the palm swifts, crested swifts, white-breasted kingfisher, broad-billed rollers, lesser concals, Tickell's flowerpecker, babblers, common bulbuls, common wren warblers, bush larks, florikin, sarus cranes, little pond heron, bitterus, black-backed geese, whistling teal, and pink-headed ducks have eggs. Besides, many other species which breed at this time in the North-West Provinces and Central India. At the end of the month, the blue-breasted quail, bronzewinged jacana, watercock, ruddy rail, and great heron begin to pair and build.

In Central India, the shikra, the dusky crag martin, most of the nightjars, cuckoo shrikes, small minivets, blue redbreasts, rufousbellied wren babblers, black-headed orioles, robins, chats, Hodgson's wren warbler, rufous-fronted wren warbler, treepies, brahminy mynahs, bush larks, crown crest larks, plovers, brown rails, herons, and white ibis are the characteristic birds that breed. While Jerdon's green bulbul, the black-backed green bulbul, the allied wren warbler, the Indian titlark, the green amadavat, the bronze-winged jacana, the white-breasted waterhen, the egrets, pond herons, cattle herons, and bitterns begin pairing and building at the close of the month.

In Southern India, the lesser kestril is breeding in the Nilgiris. Also the house swallow and the hill swiftlet, the orange minivet, the white-bellied drongo, the black-naped azure flycatcher, the whitespotted fantail, the blue redbreast, the yellow-eyed babbler, quaker thrushes, white-throated wren babbler, langhing thrush, rufous-tailed and jungle babblers, most of the bulbuls, the ashy and fuscous wren warblers, the rufous grass warbler, the Indian amadavat, the sky lark, the woodpigeon, the peafowl, the red spur fowl, and courier plovers have 
eggs wherever the birds are found, and the rufous-bellied munia is building at the end of the month.

The sea terns and gulls lay throughout this month on the rocky islands in the bay of Bengal, Indian ocean, Red sea, and Persian gulf. 


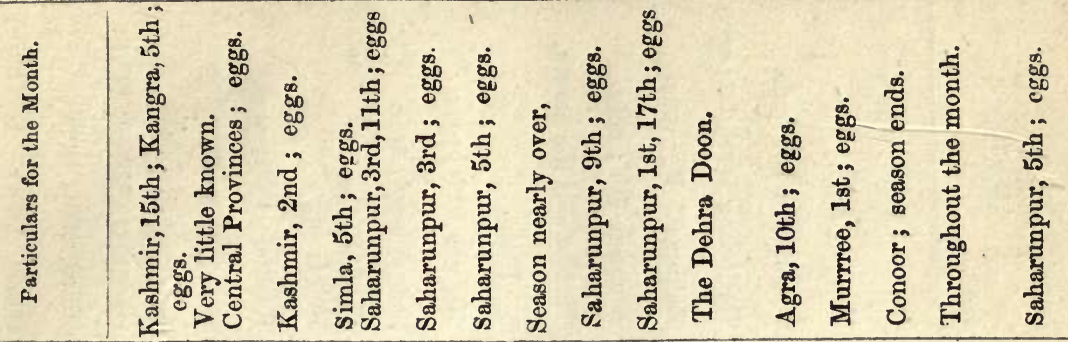

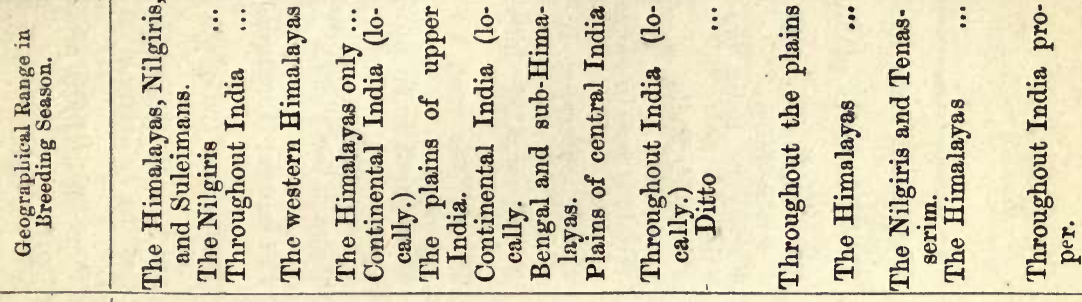

ตำ

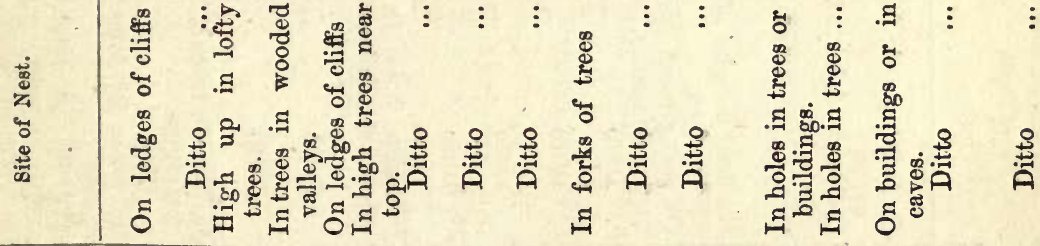

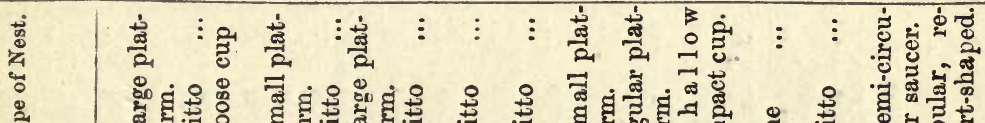

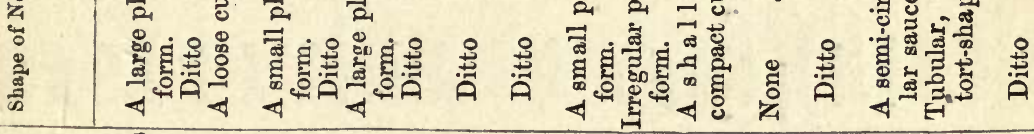

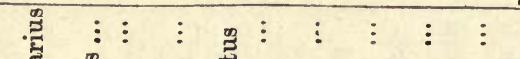

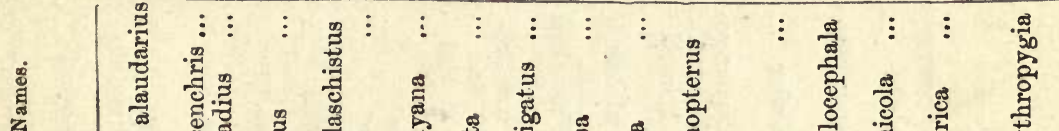

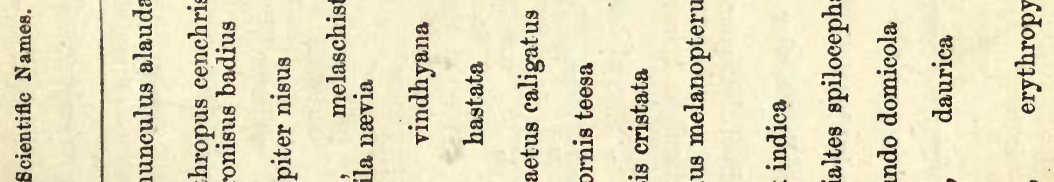

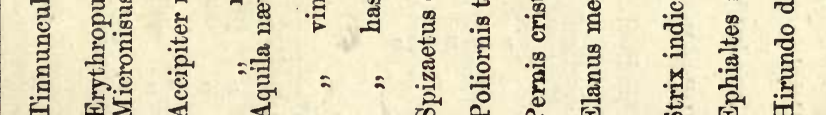

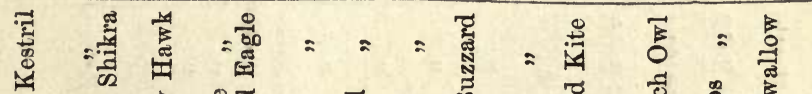

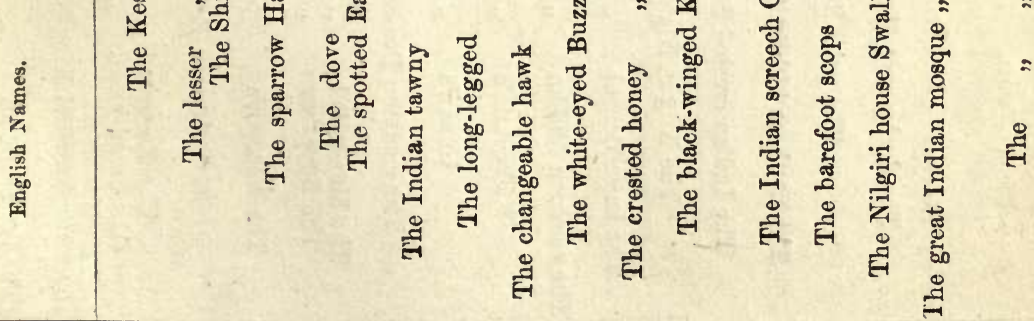

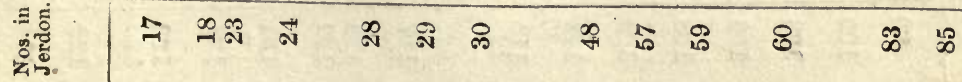




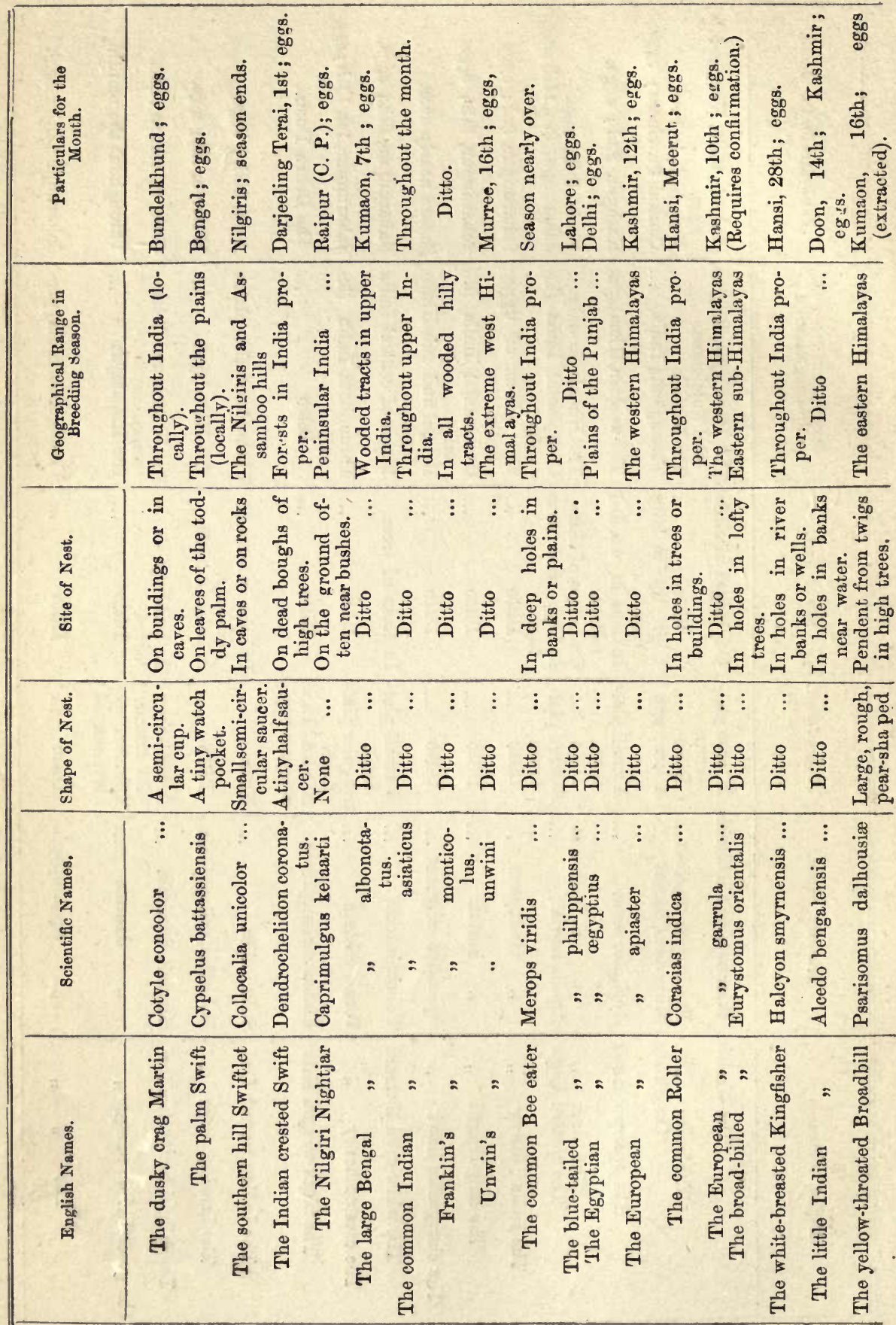

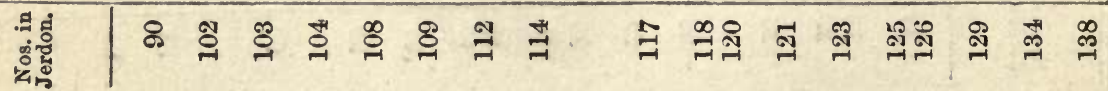




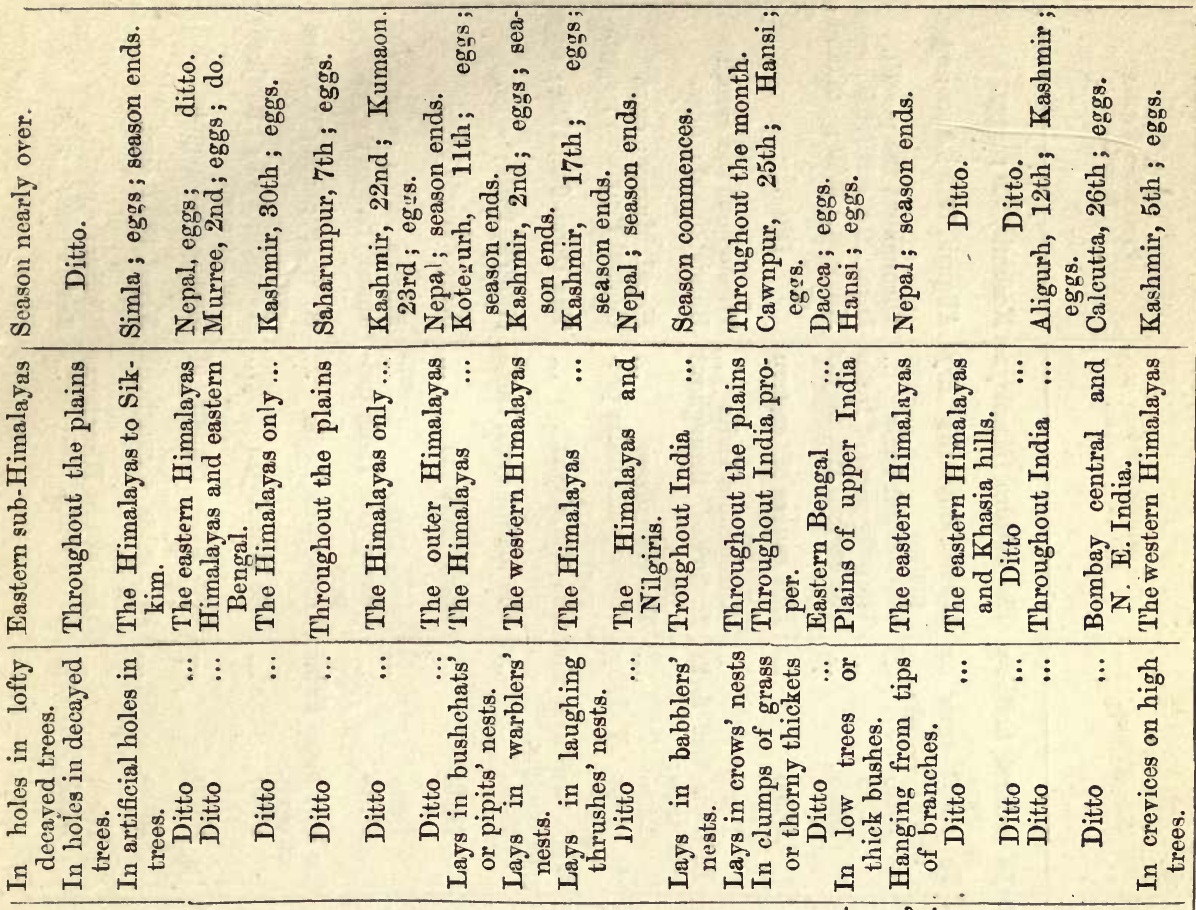

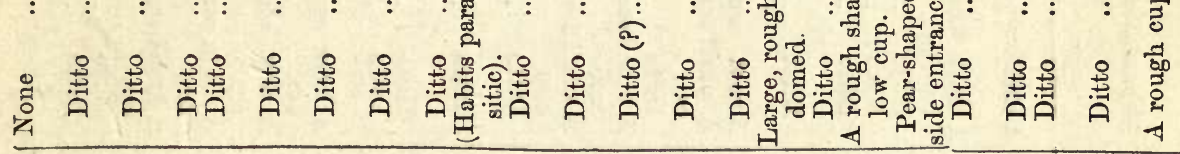

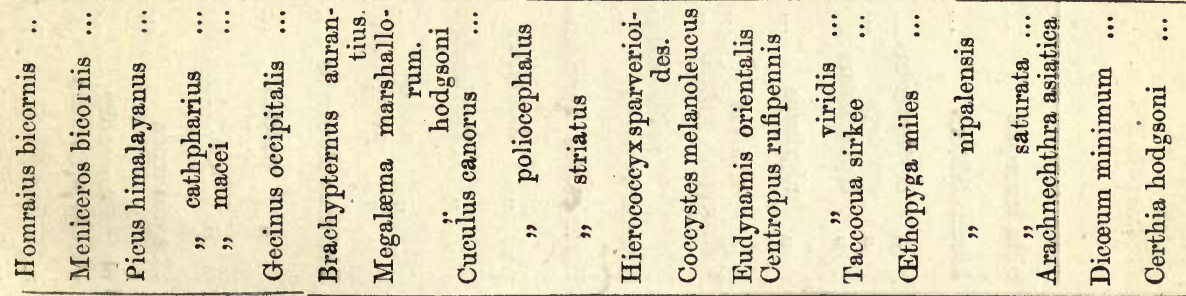

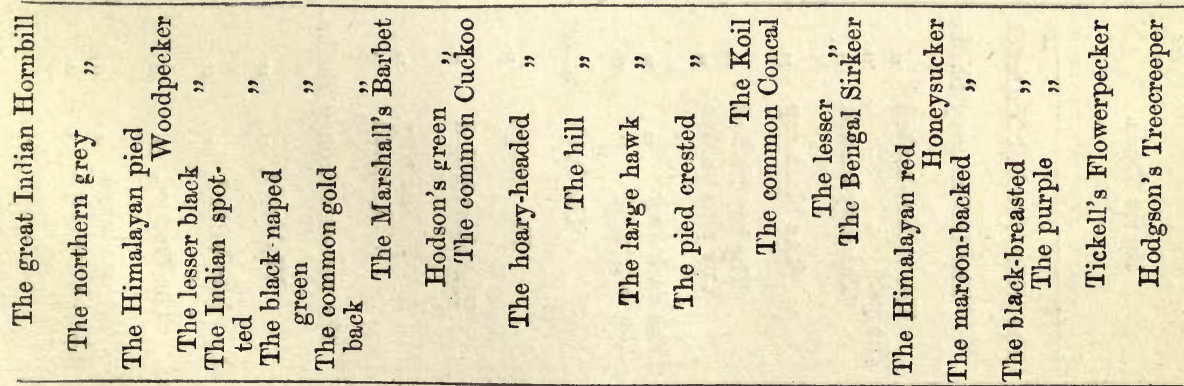

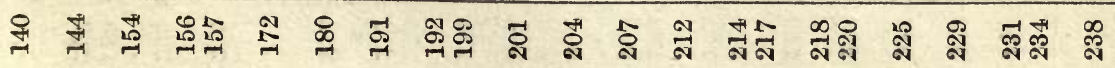




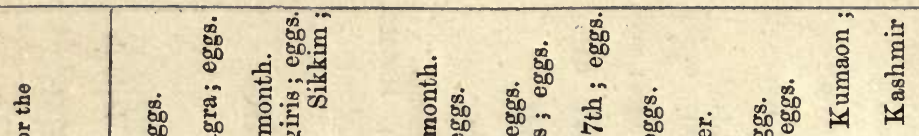

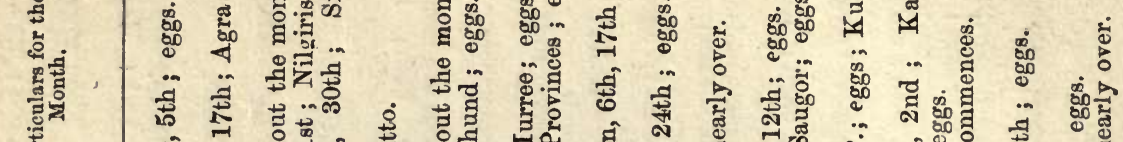

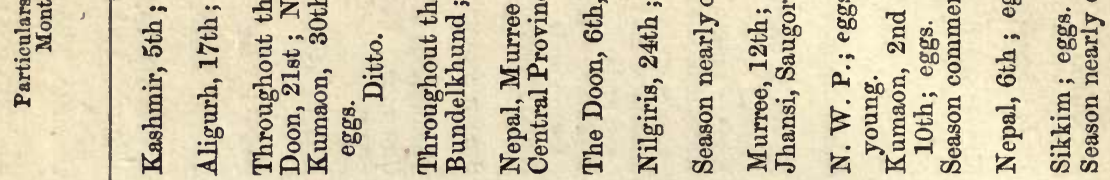

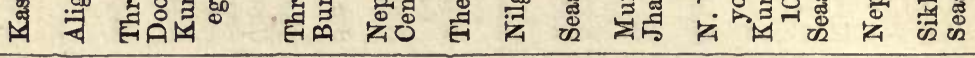

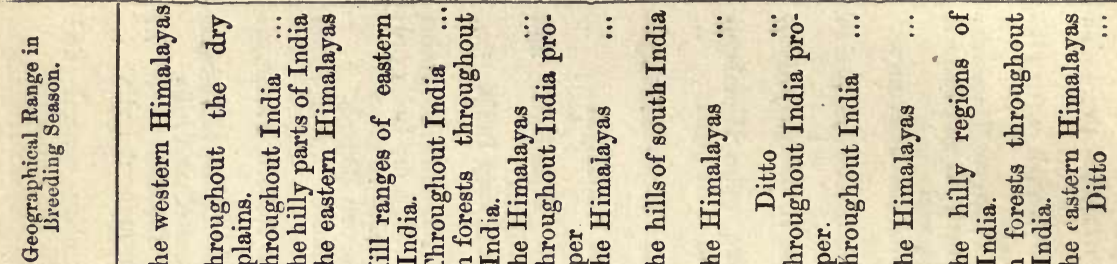

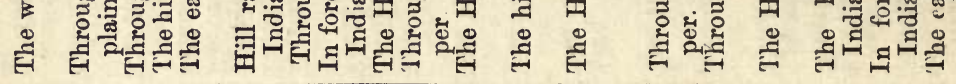

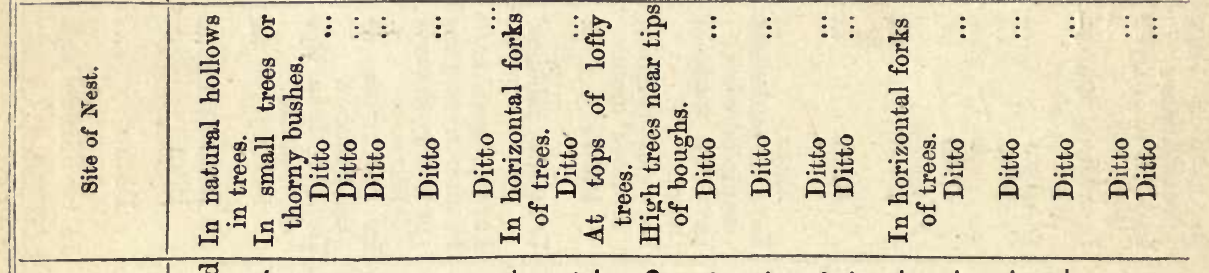

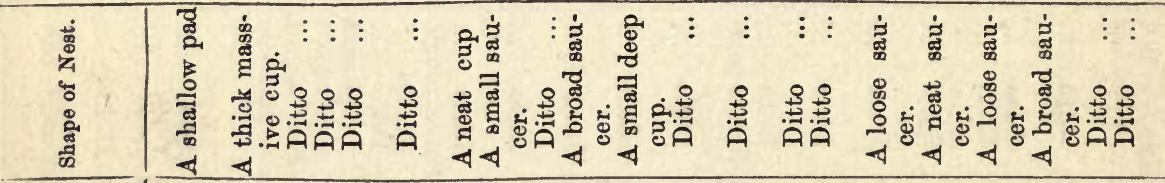

\begin{tabular}{|c|c|c|c|c|c|c|c|c|c|c|c|c|c|c|c|c|}
\hline 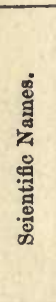 & 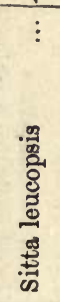 & 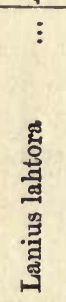 & 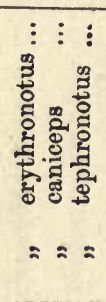 & 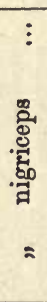 & 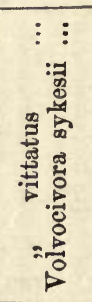 & 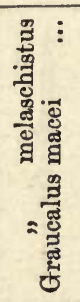 & 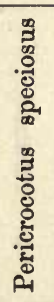 & 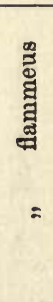 & 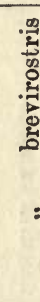 & 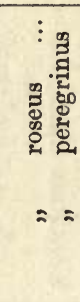 & 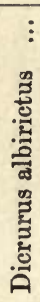 & $B$ & & & 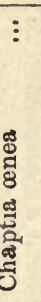 & 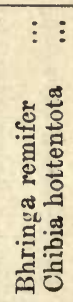 \\
\hline 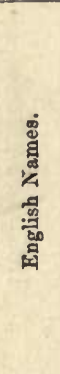 & 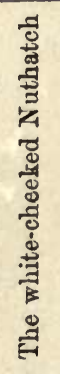 & 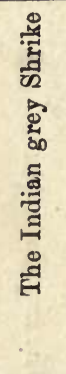 & 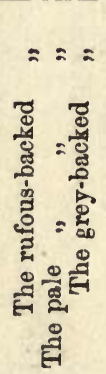 & 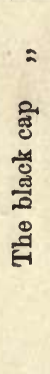 & 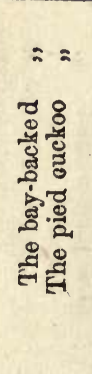 & 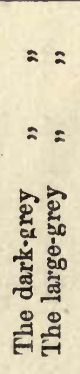 & 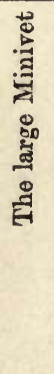 & 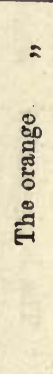 & 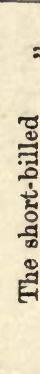 & 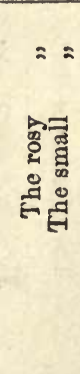 & 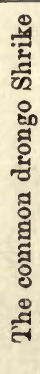 & & & & : & 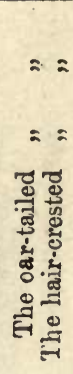 \\
\hline
\end{tabular}

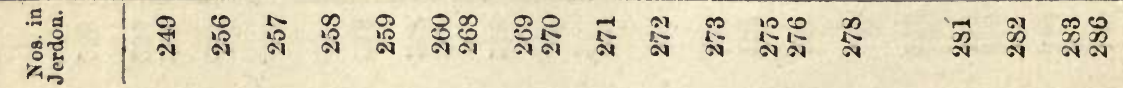




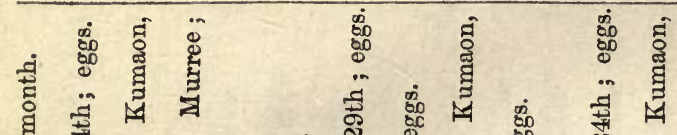

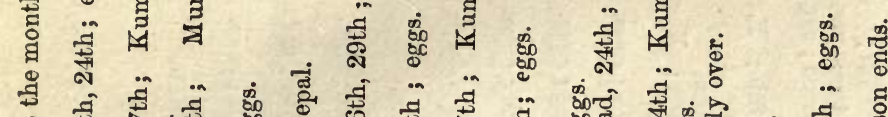

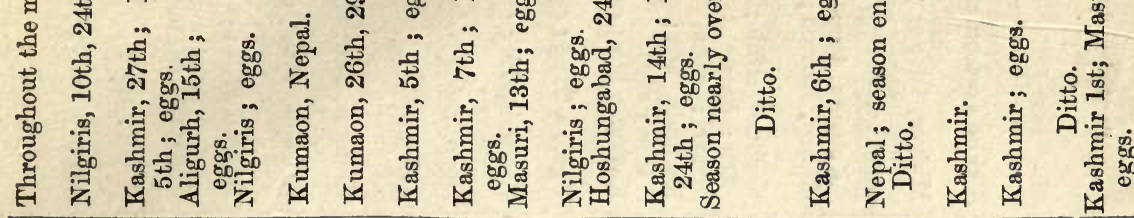

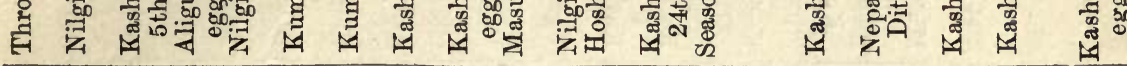

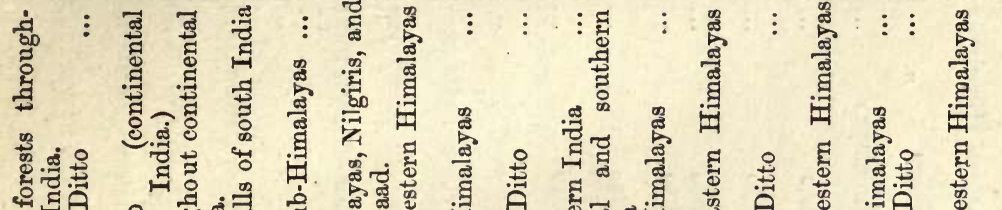

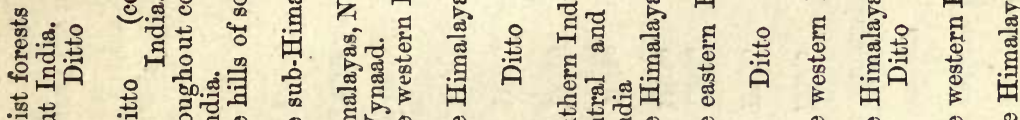

荡苟 A

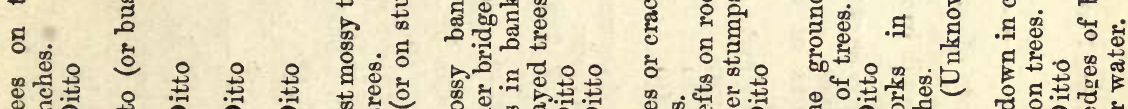

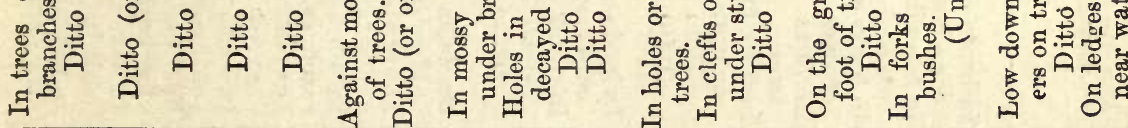
实 ४

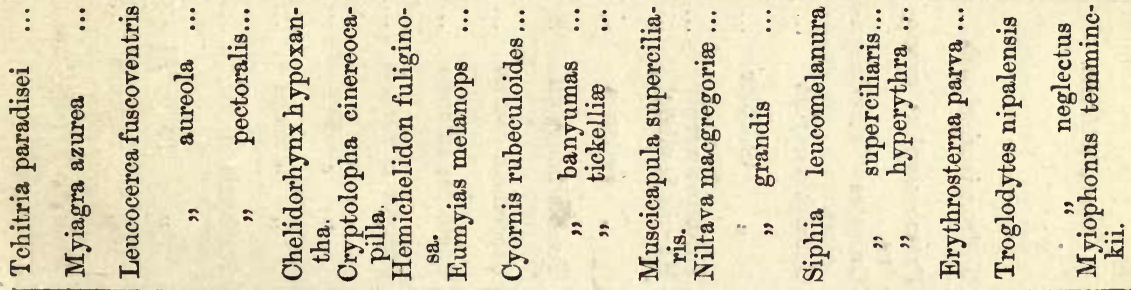

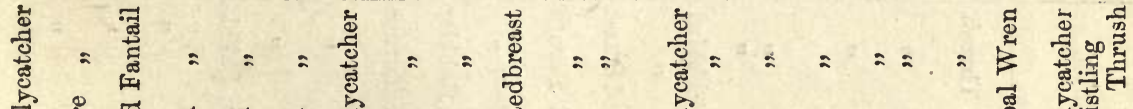

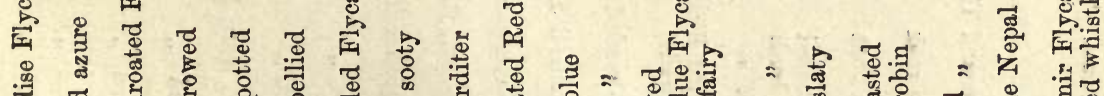

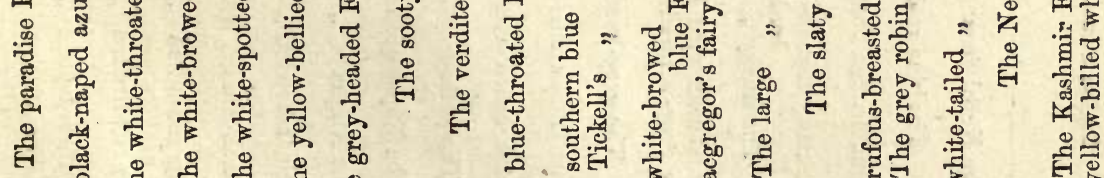
झ 일

है झ

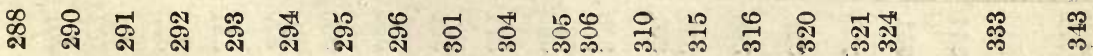




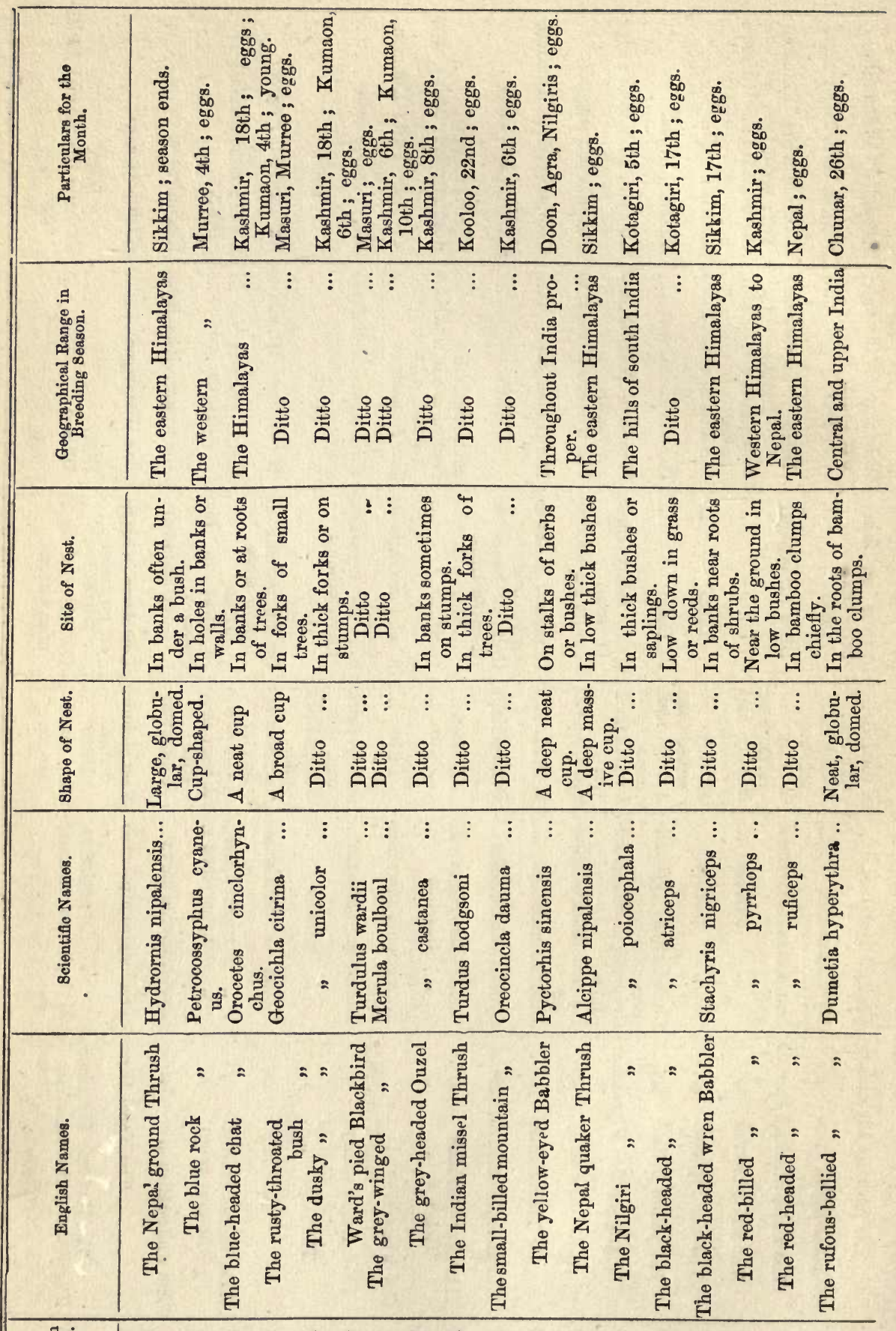

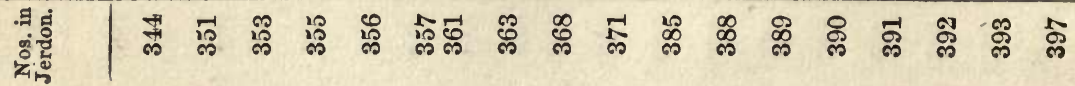




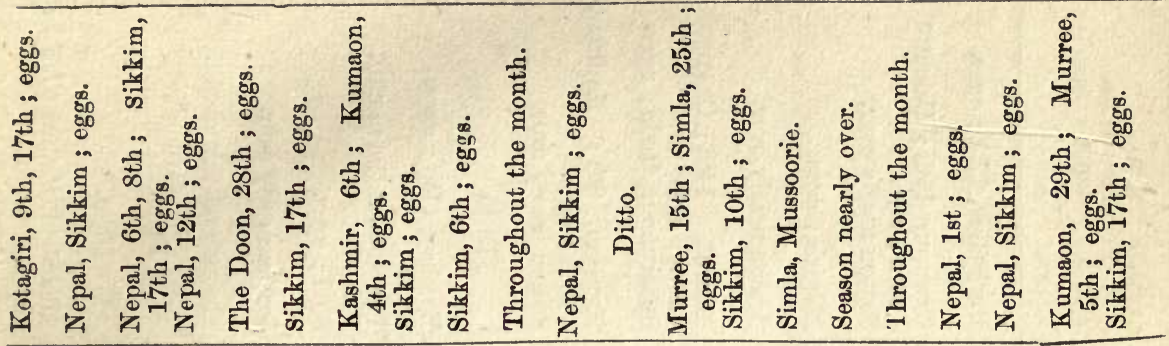

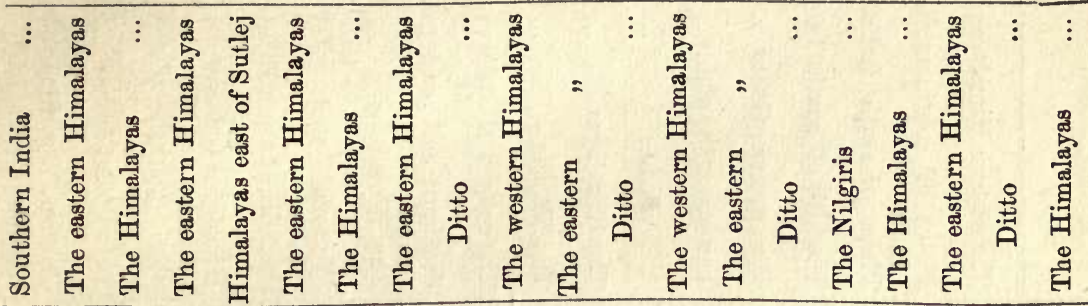

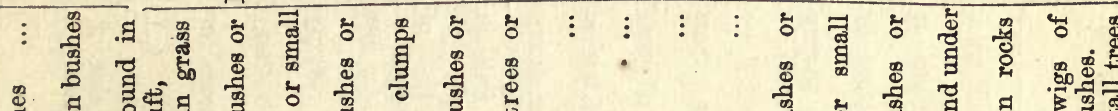

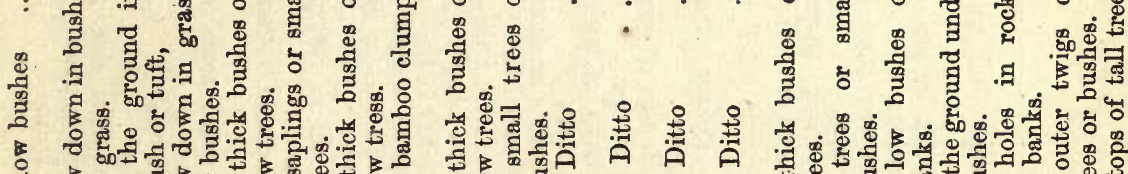
等,

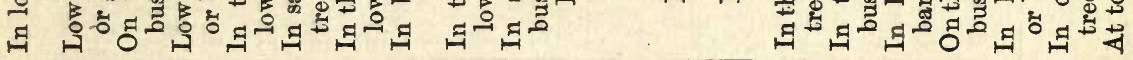

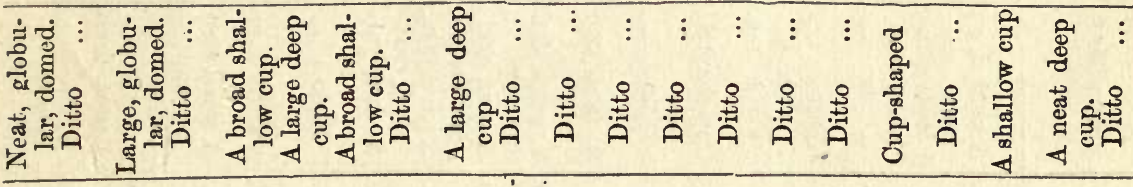

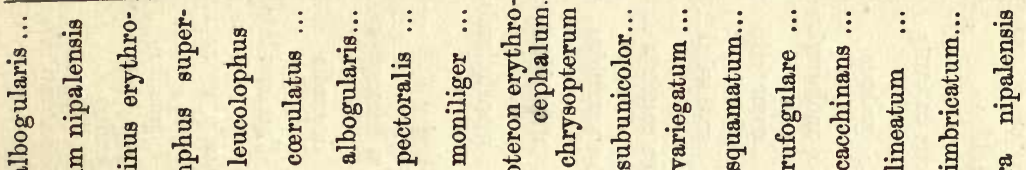

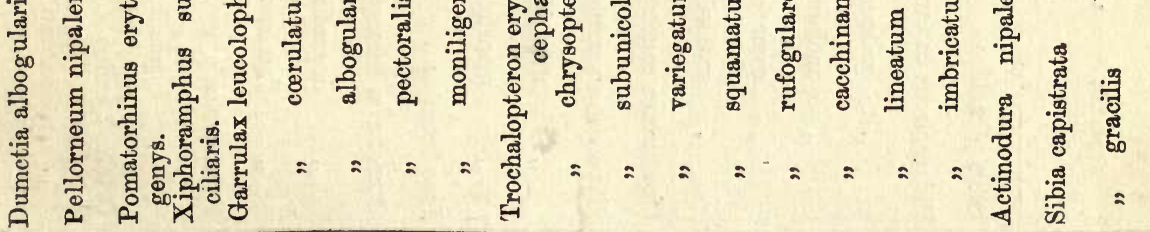

量器

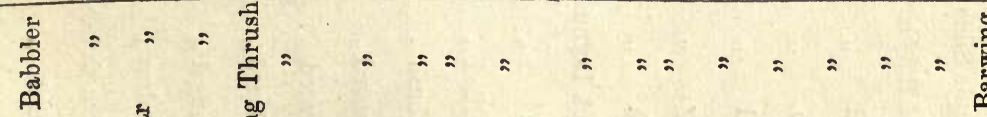

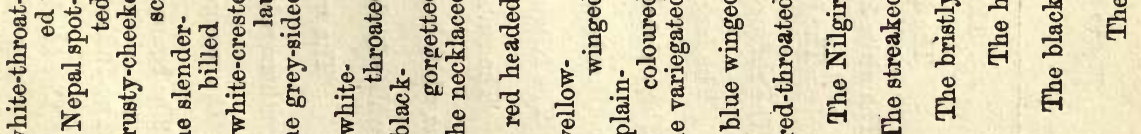

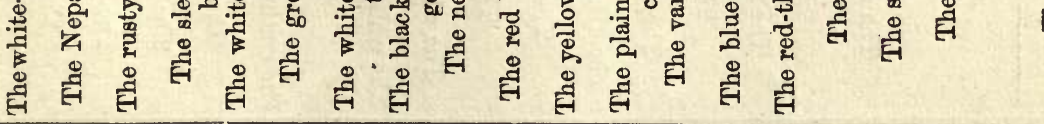

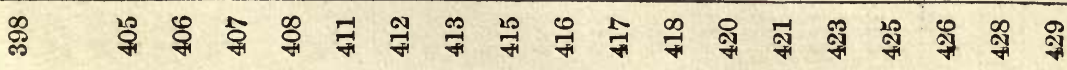




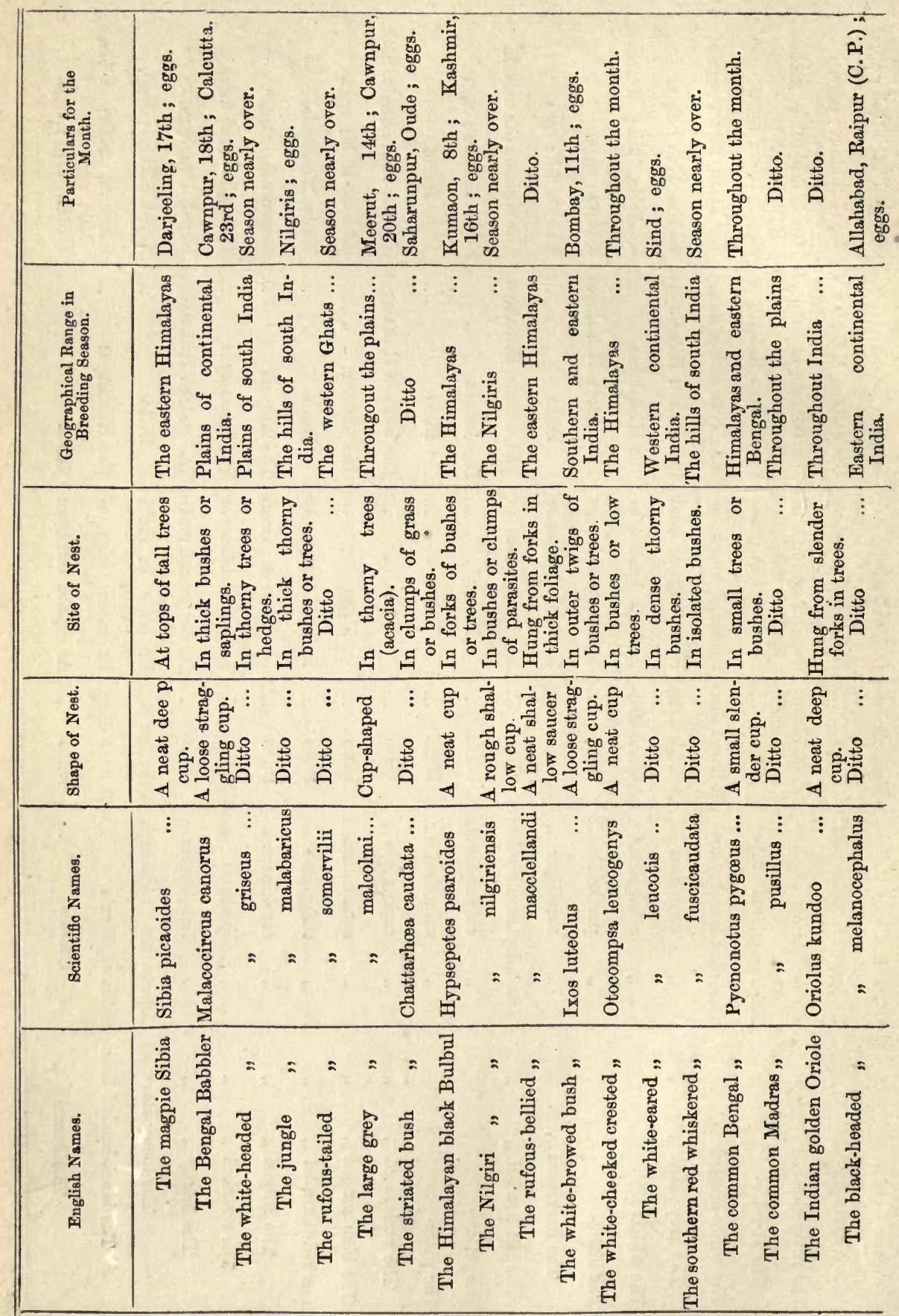

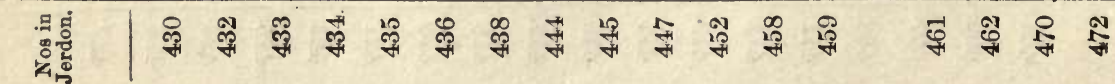




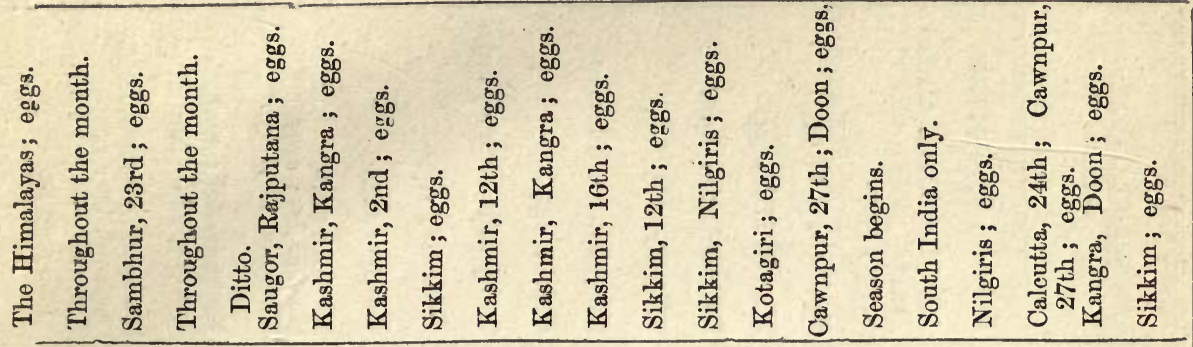

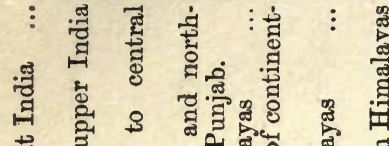

苛

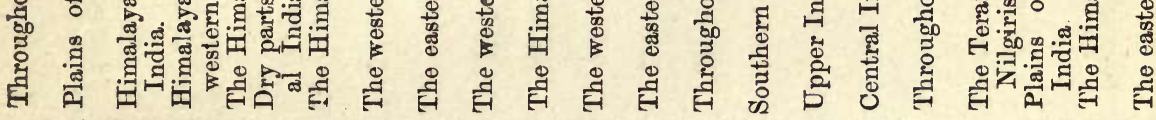

。

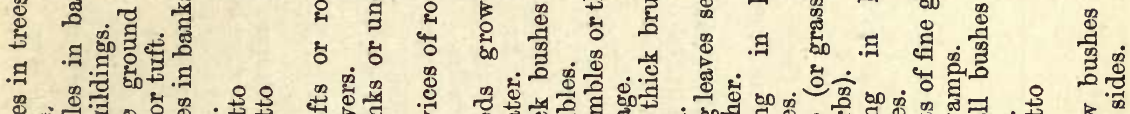

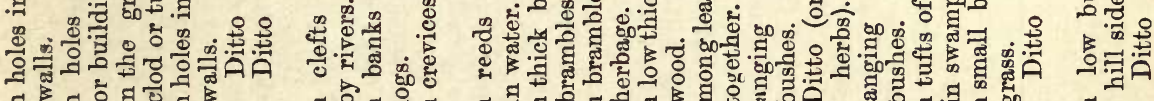

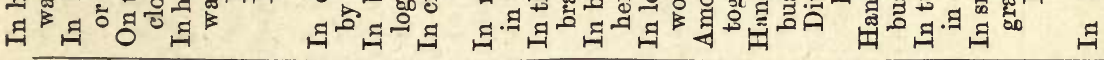

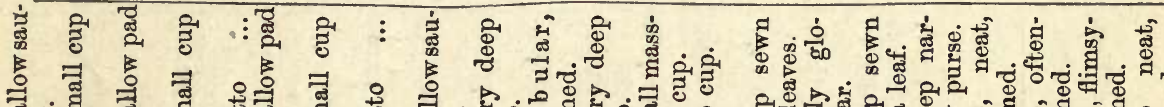

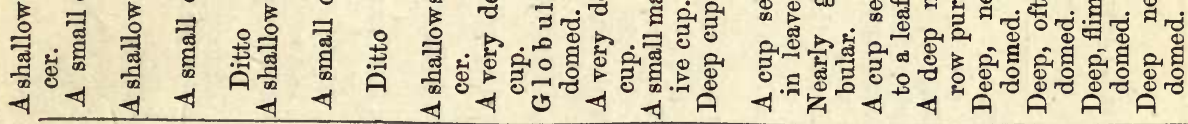

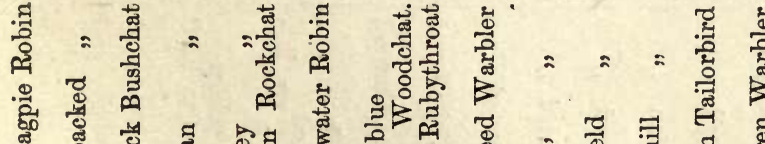

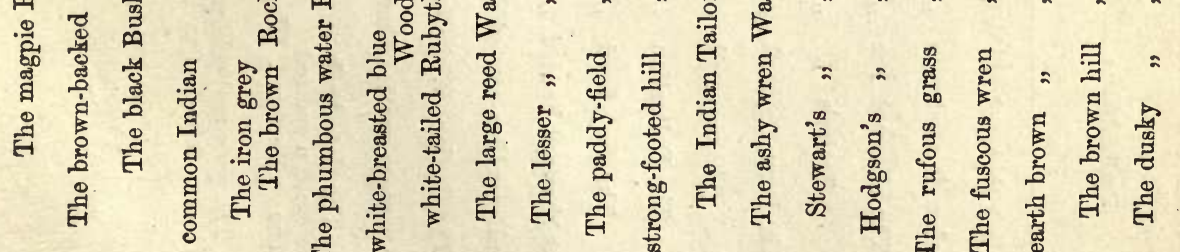
से है 랄 焉

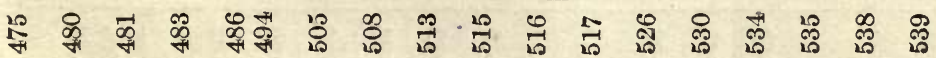




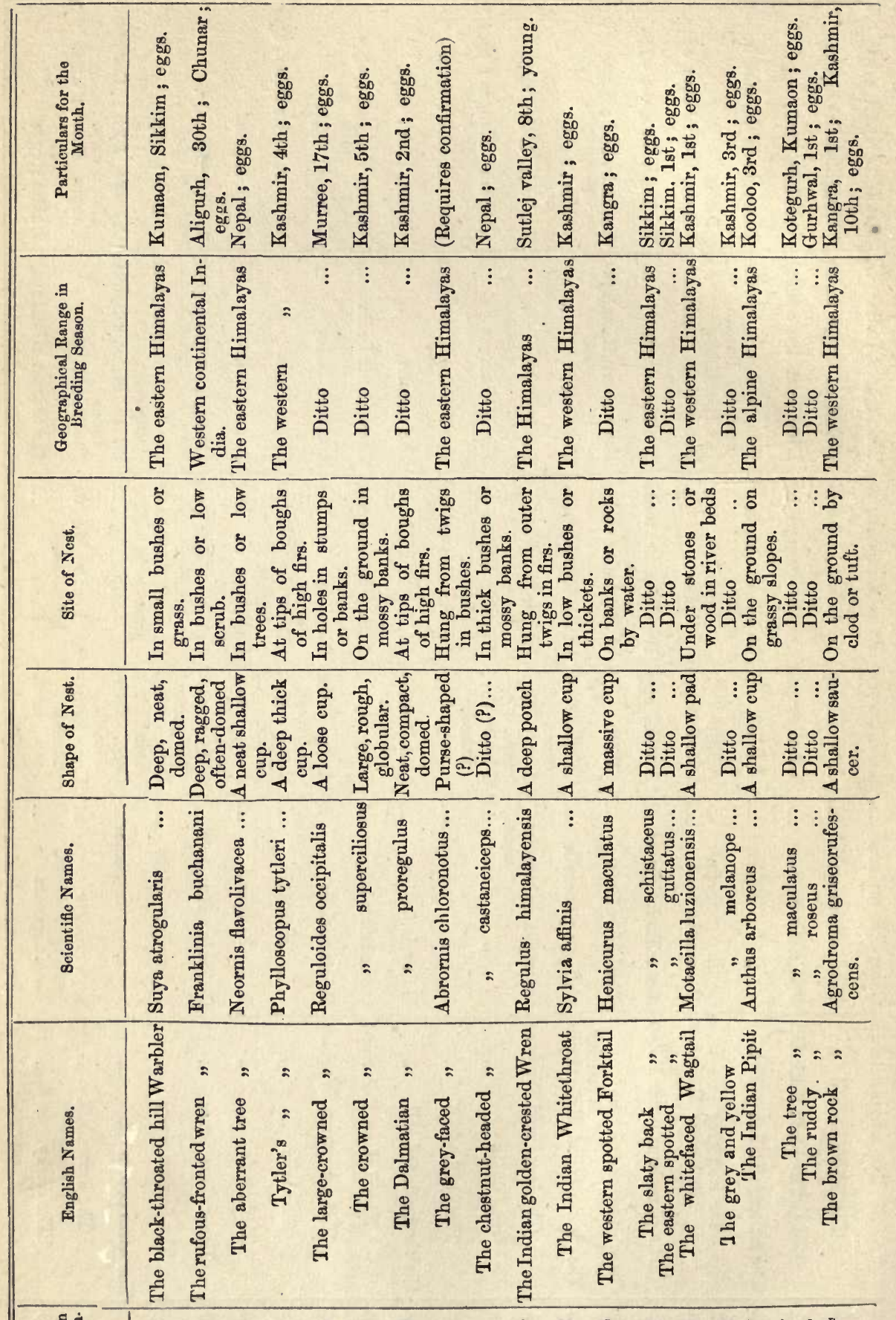

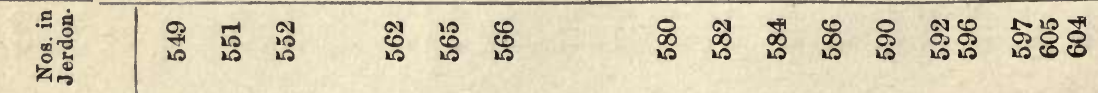




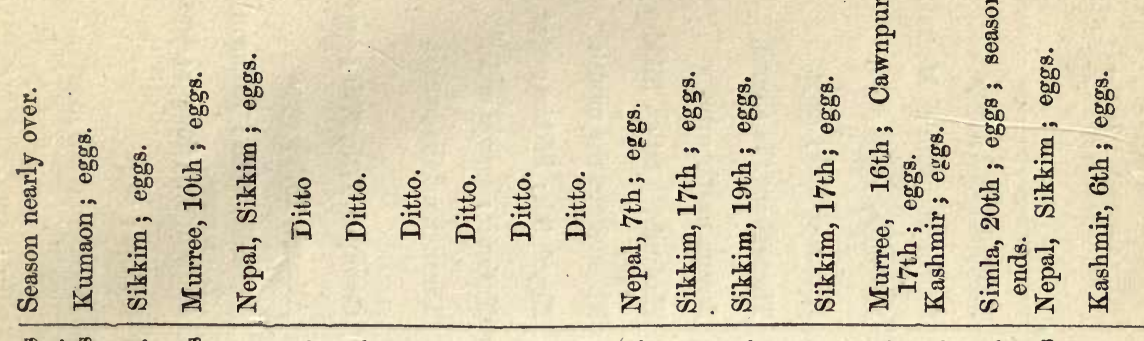

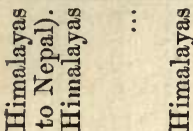

(t)

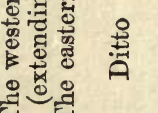

. है

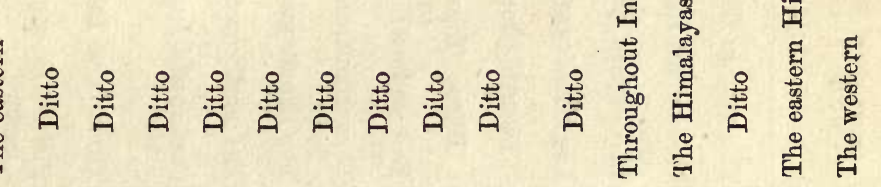

今.

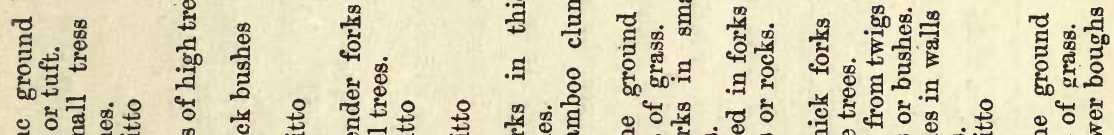

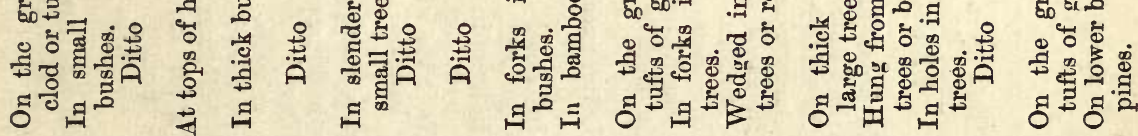

登:

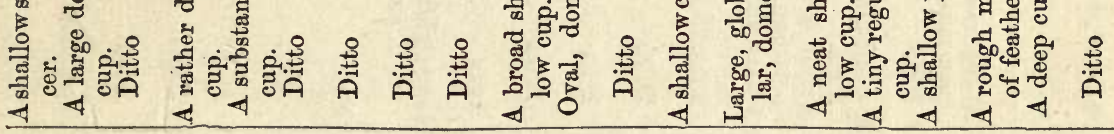

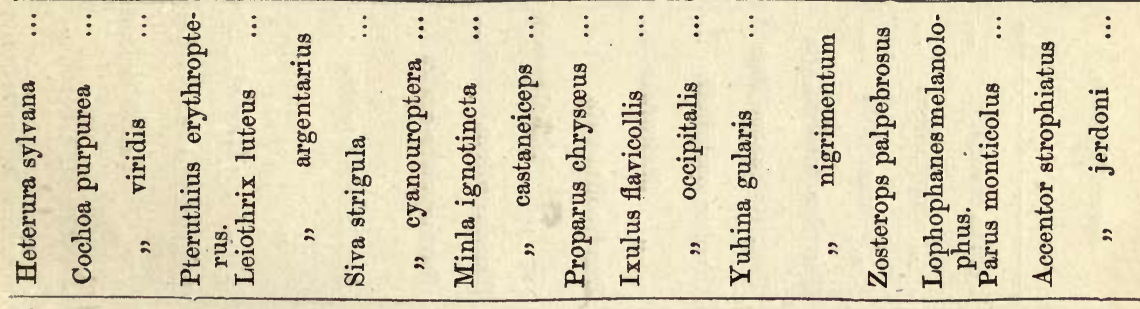

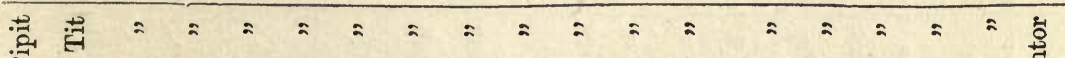

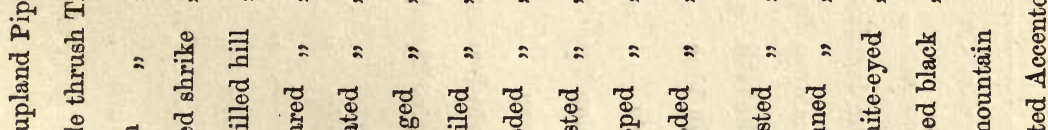

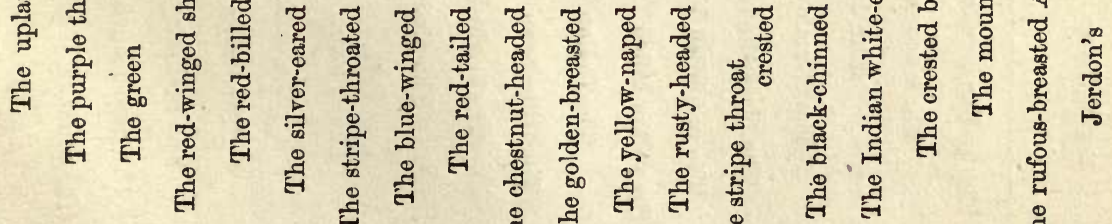

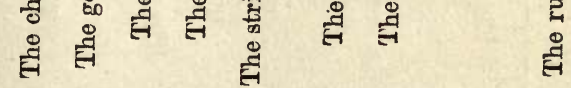

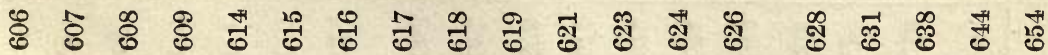




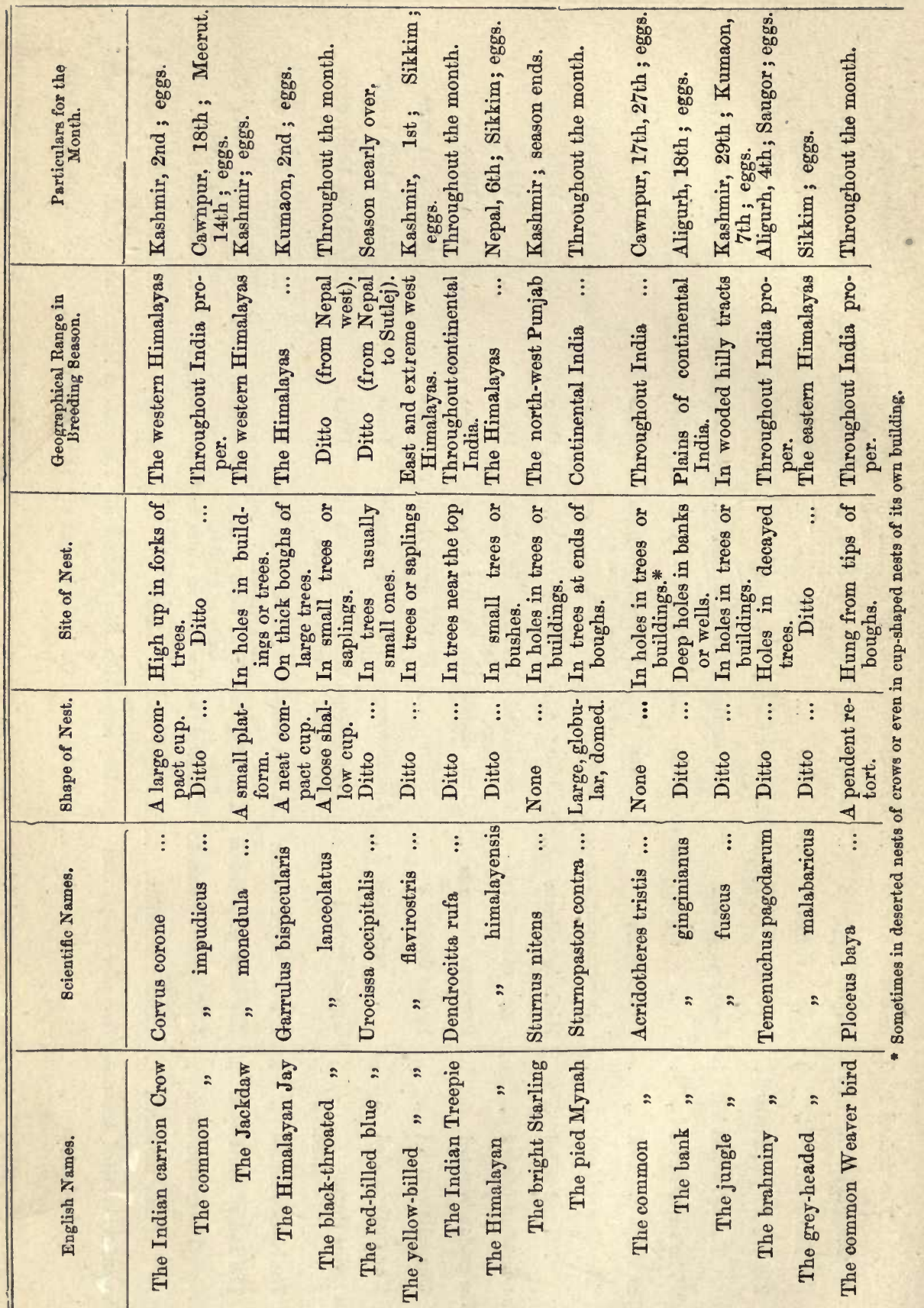

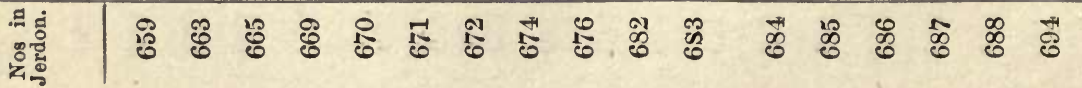




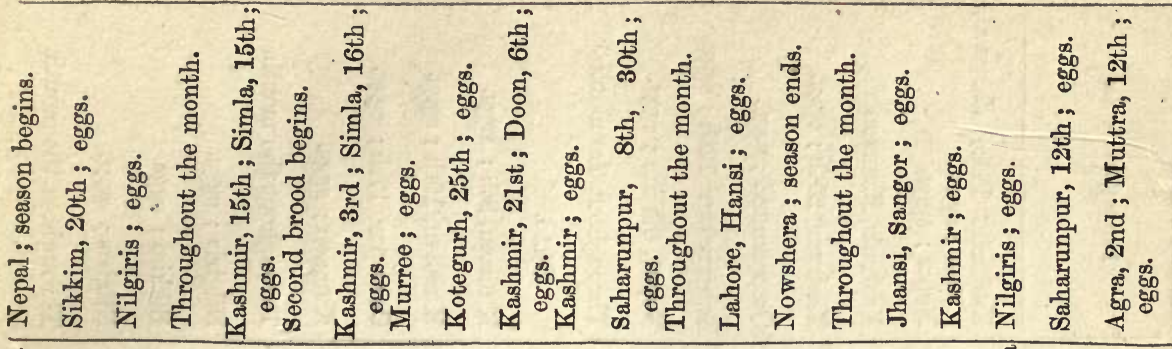

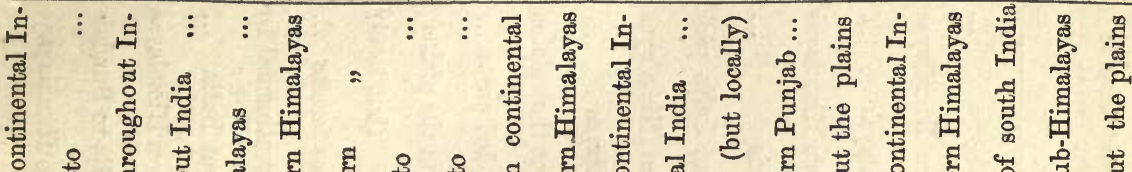

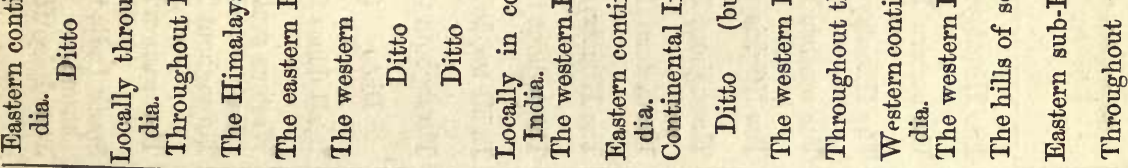

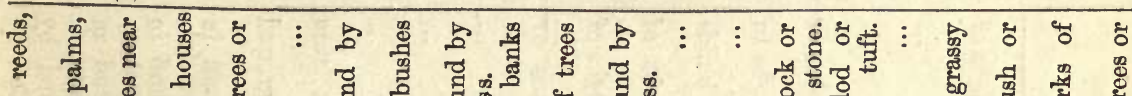

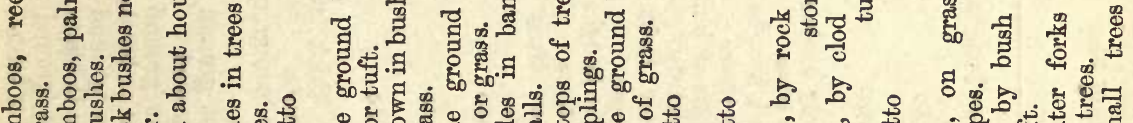
至

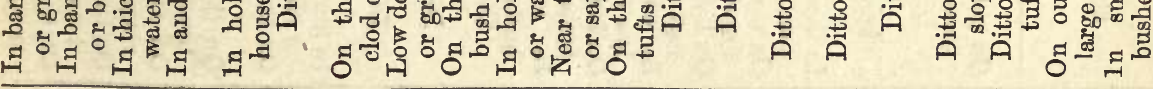

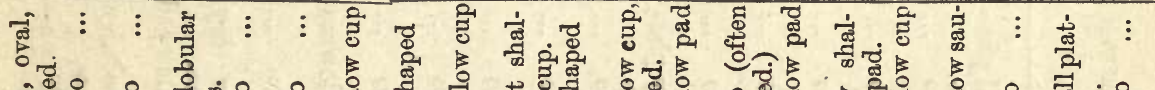

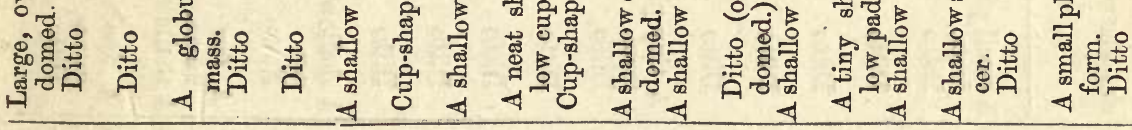

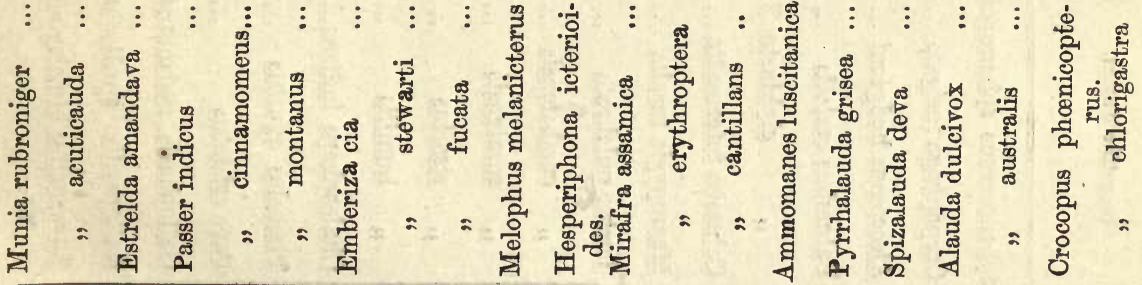

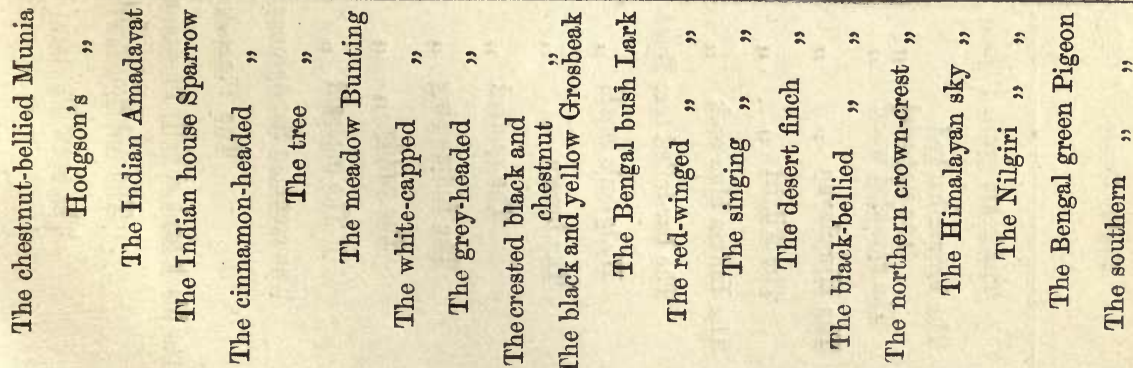

䑻 


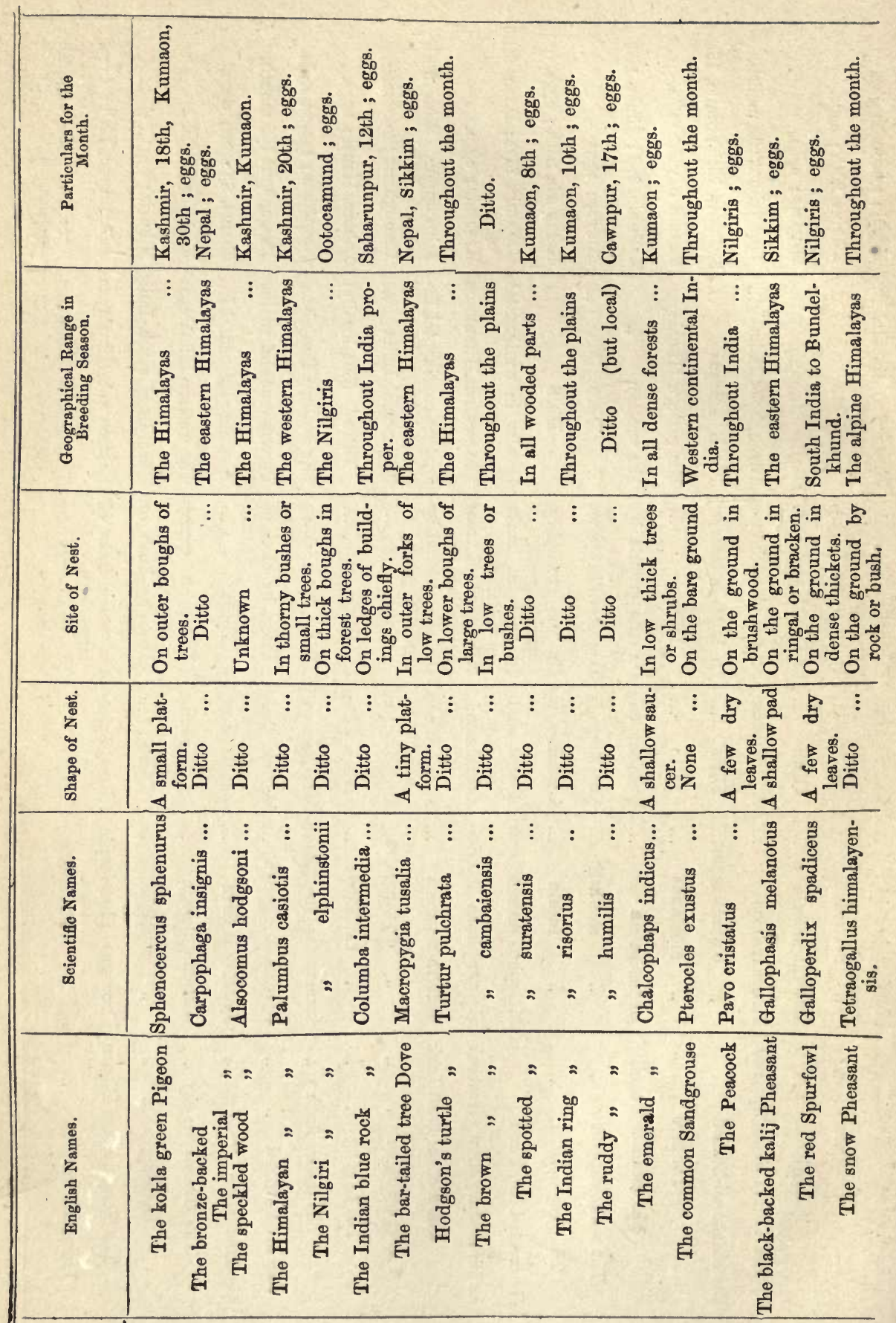

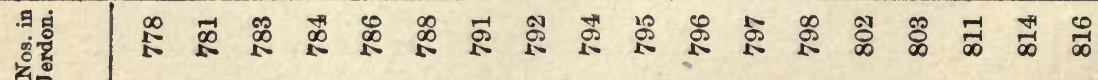




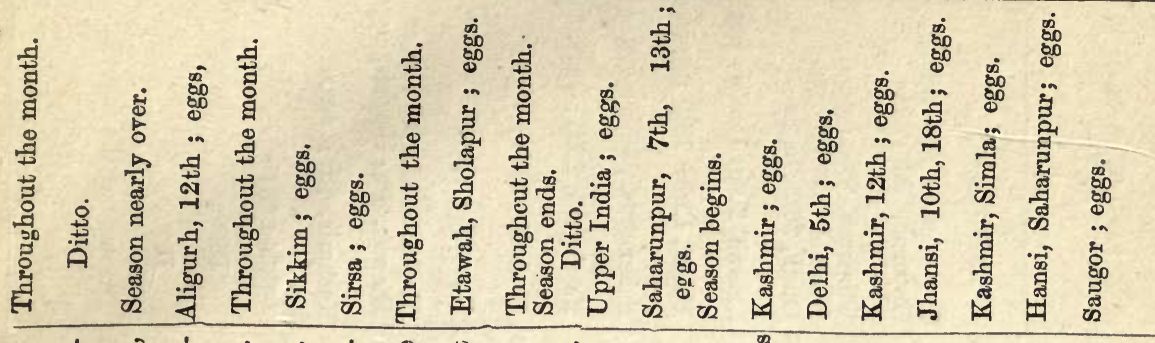

采嵒

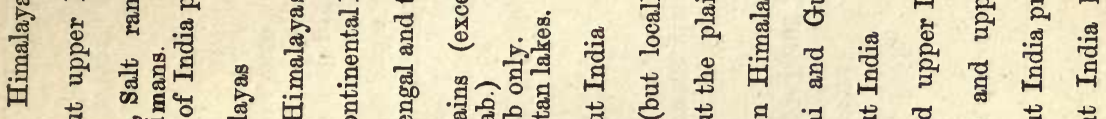
范

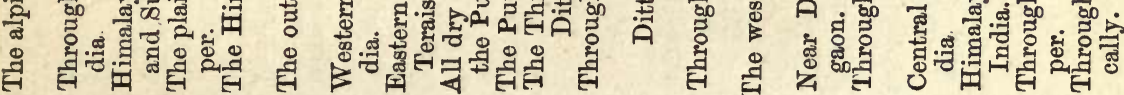

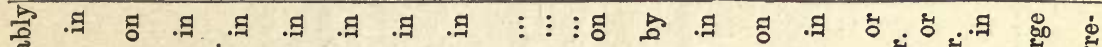

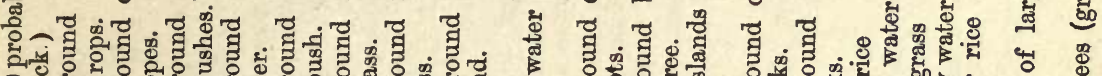

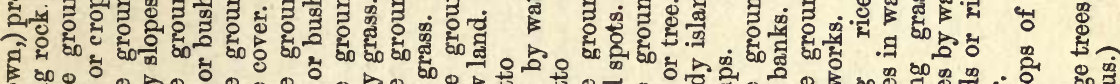
要 ह t

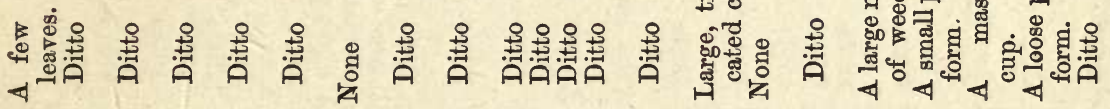

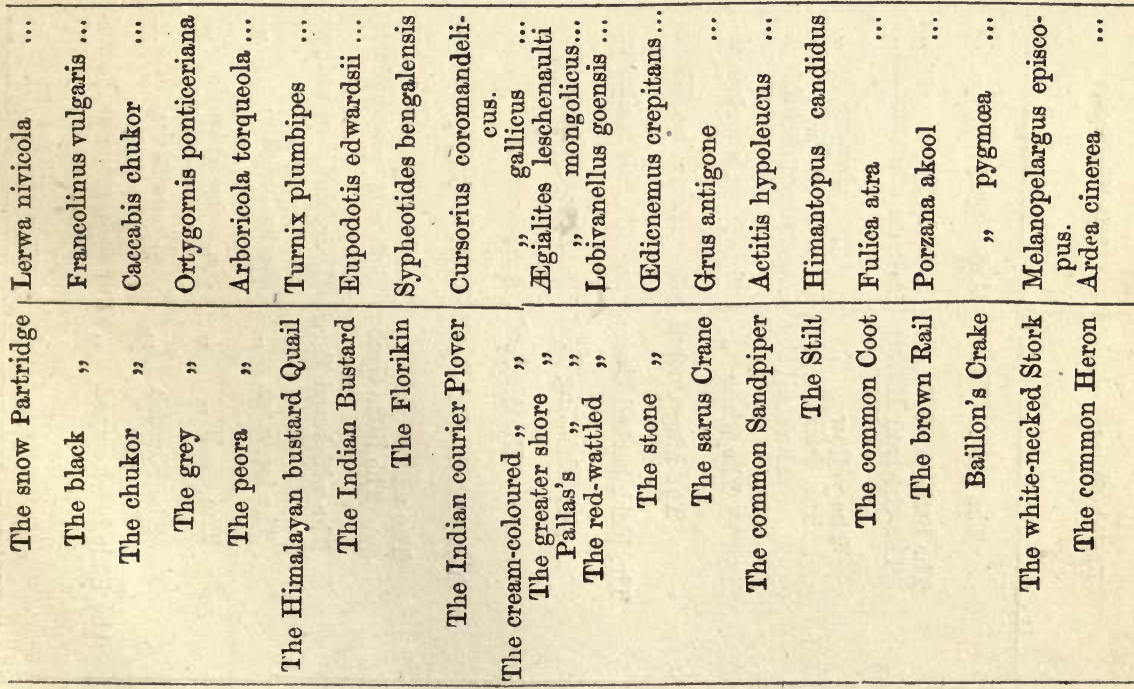

둥 


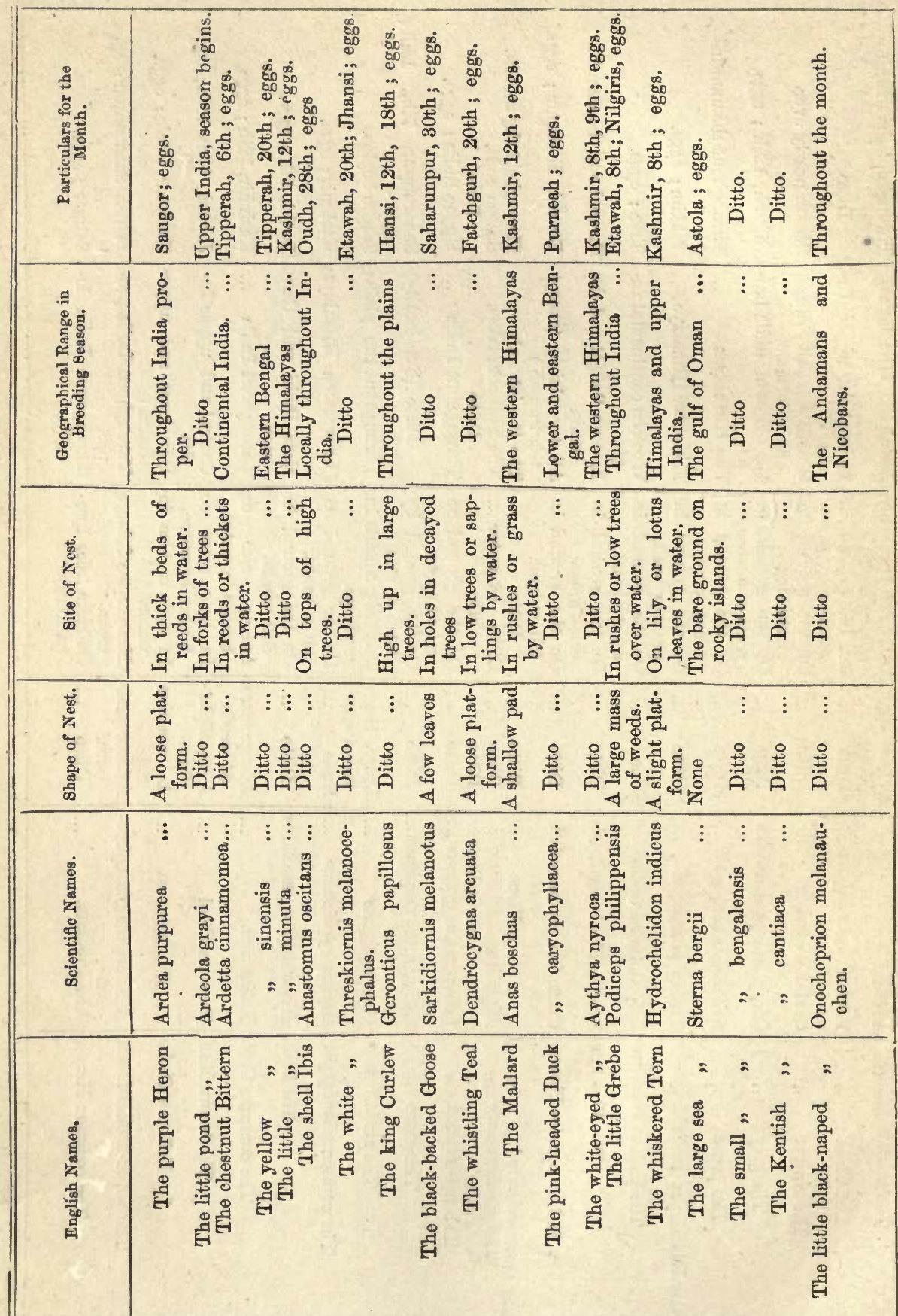
구

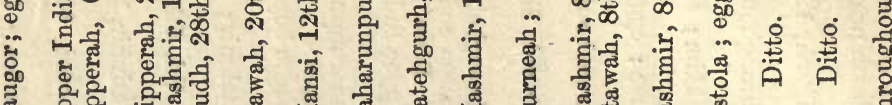

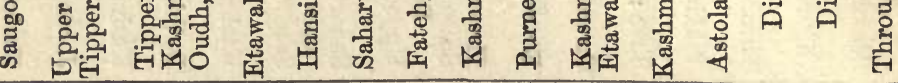

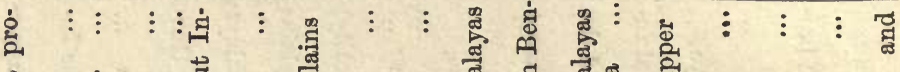





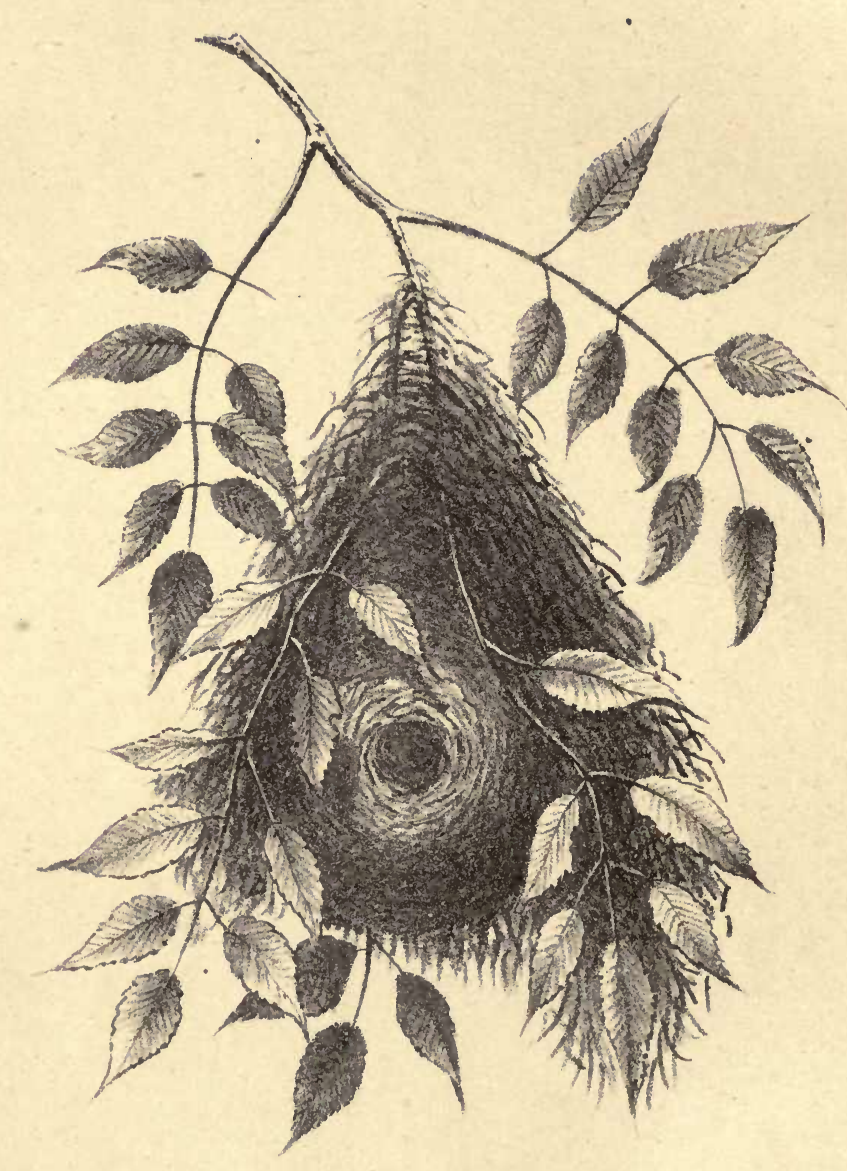

MARSHALL, DEL.

NEST OF THE YELLOW-THROATED BROADBILL. 


\section{JULY.}

This is in the plains the principal month for taking the eggs of the water-birds, wren warblers, and munias, while in the Himalayas the finches and buntings are the most numerous breeders. The birds of prey, parrots, hornbills, most of the woodpeckers and the barbets, the nuthatches and creepers, thrushes and blackbirds, and tits of almost all kinds, have ceased to lay. The shrikes, small minivets, the turtle doves, ringdoves are still breeding everywhere. And throughout the plains the eggs of the common drongo, tailor bird, rufous grass warbler, peafowl, bustard quail, red-wattled plovers, purple coots, common coots, and waterhens, may be taken.

In the Himalayas, the eggs of the mosque swallow, the swift, the roller, the Marshall's barbet, the common and large hawk cuckoos, paradise flycatcher, grey-headed and verditer flycatchers, the greywinged blackbird, striated jay thrush, Nepal quaker thrush, red-billed wren babbler, several of the laughing thrushes, some of the bulbuls, bushchats, hill warblers, tree warblers and pipits, the rufous-breasted accentor, blue magpie, mynahs, munias, sparrows, bartailed tree doves, emerald doves, kalij pheasants, Hodgson's partridges, chukor, peora partridge, bustard quail, rails; and bitterns may still be found, but the season is practically over, except in the more elevated ranges and towards the far west. Eggs of buntings and finches are found throughout the ranges. The golden woodchat begins to pair and build during this month.

In the PunJaB, the crested honey buzzard is still laying. The mosque and cliff swallows have their second brood. The white-breasted kingfisher and common gold back woodpecker breed throughout the month. Also the koel, coucal and sirkeer, the white-eared bulbul, the golden oriole, brown-backed robin, Stewart's wren warbler, and all other wren warblers that occur there, the common crow, mynahs, pin-tailed munias, bushlarks and black-bellied finchlarks, the common sandgrouse, the black partridge, bustard, courier plover, red-wattled plover, white-necked stork, common heron, egrets, pond herons, cattle herons, green bitterns, night herons, and spoonbills have eggs. By the end of the month the black-winged kites, the large button quail, and Blyth's water hen (very rare) are beginning to pair and build. 
In the North-West Provinces, the birds of prey have al lceased to lay. Eggs of all the resident swallows may be found, and the palm swift has its second brood. The cuckoos, coucals and sirkeers are laying. The large grey cuckoo shrike, the fantail, the yellow-eyed babbler, the rufous-bellied wren babbler, all other babblers, except the reed babbler, the golden oriole, the wren warblers, white-eyed tits, tree pies, mynahs, weaver bird, pin-tailed munia, bushlarks, finch larks, stone plover, still have eggs; while those of the sarus crane, pheasant-tailed jacana, Baillon's crane, white-necked stork, herons, and egrets of all kinds, spoonbills, Ibis's geese, teal, and snakebirds are found throughout the month. The marsh terns also breed in this month, and the great rufous wren warbler, striated weaver birds, cinnamon bitterns, and spotted billed ducks commence to pair and build.

In Bengal, the palm swift has its second brood. The broad-billed roller is believed to be breeding, but its eggs have not been taken. The coucal, tailor-bird, white-breasted kingfisher, common babbler, yellowbellied wren warbler, white-winged green bulbul, chestnut-bellied munia and spotted munia, and the bustard quail lay in the neighbourhood of Calcutta. The Bengal grass warbler in the eastern districts, the blue. breasted quail and florikin in the Terai districts. The bronzed-winged jacana, the water cock, Baillon's crane, the great heron, the black bittern and chestnut bittern, the pink-headed duck, and probably most of the other resident water birds lay everywhere throughout the month.

In Central India, the swallows, dusky crag martins, nightjars, koels, coucals, cuckoo shrikes, fantails, ground thrushes, wren babblers, green bulbuls, robins, rockchats, almost all the wren warblers, titlarks, treepies, mynahs, munias, amadavats, crested buntings, bushlarks, crown crest larks, painted partridges, bustard, jacanas, rails, herons, egrets, and white ibis, are laying still, while Sykes's warbler, the lesser button quail, and the larger whistling teal begin to pair and build.

In Southern INDIA, the orange minivet, the black-naped azure flycatcher, the white-spotted fantail, the yellow-eyed babbler, blackheaded quaker thrush, most of the wren warblers, the white-eyed tit, the jungle mynah, and most of the munias, appear to be the principal breeders during this month. Towards the end of it Jerdon's wren warbler, the Malabar crested lark, and the rain quail commence to pair and build. 


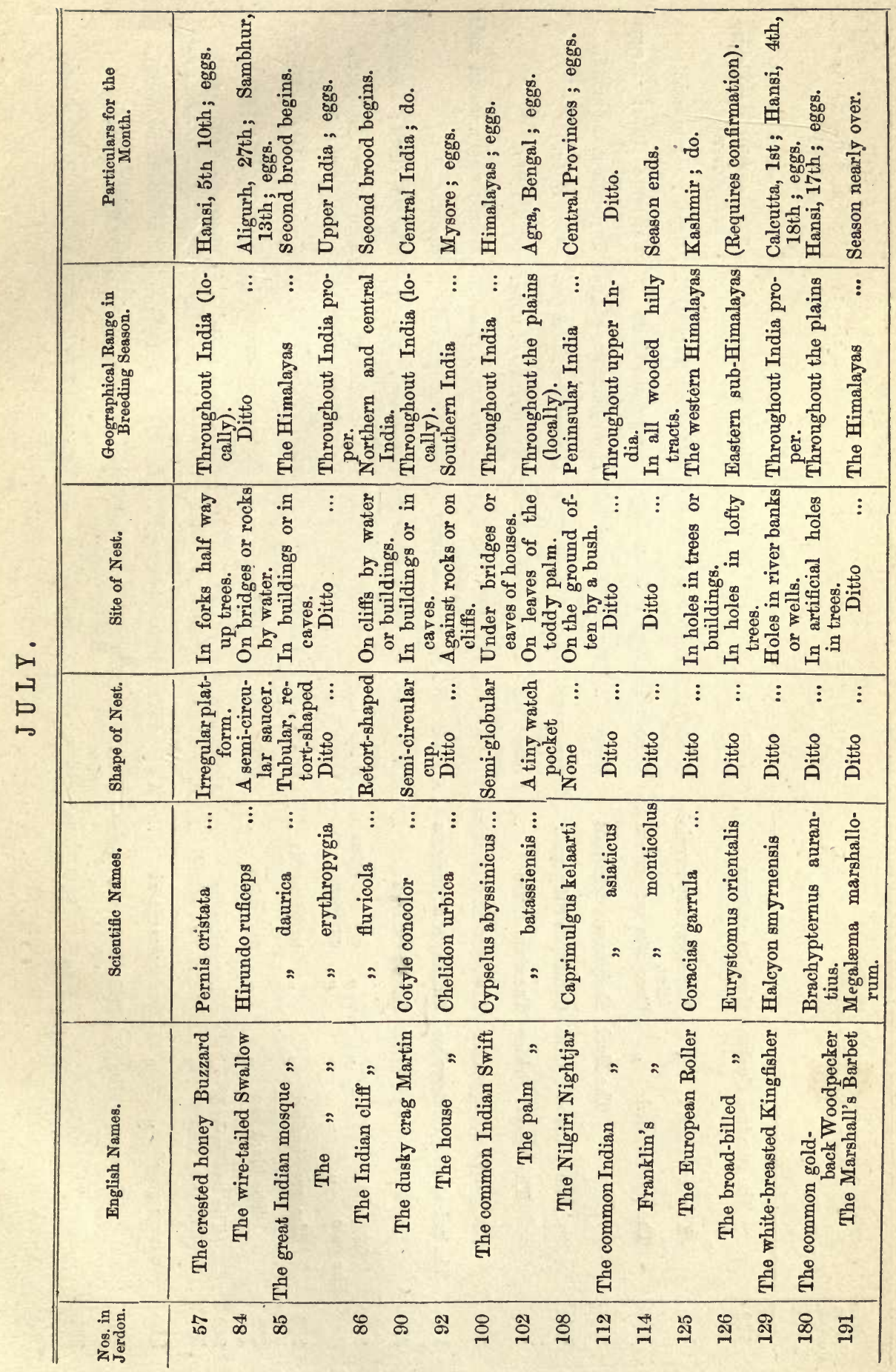




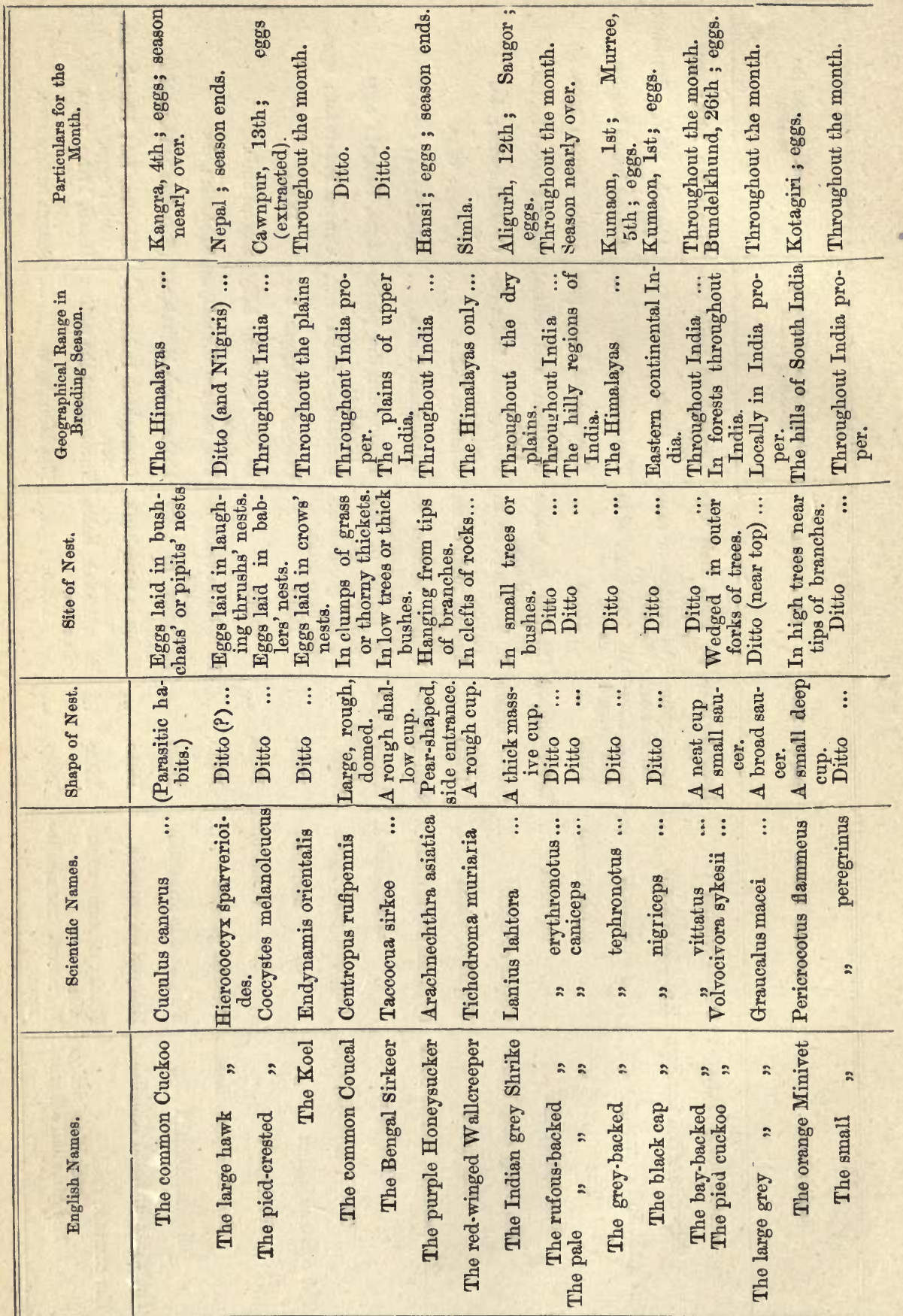

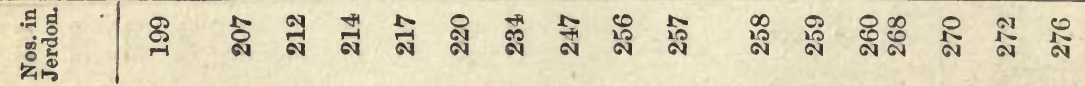




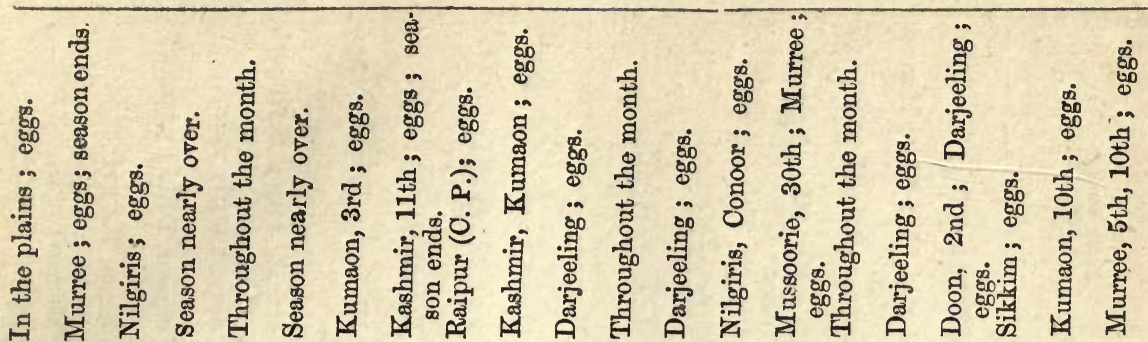

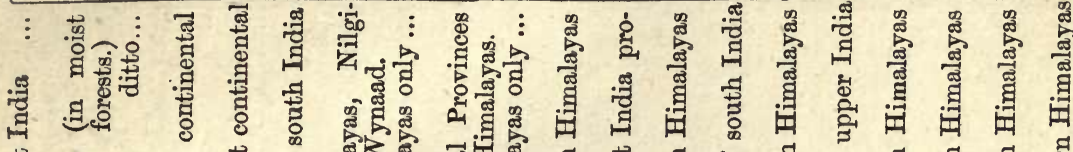

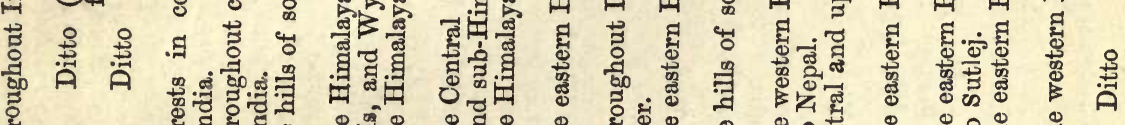
है

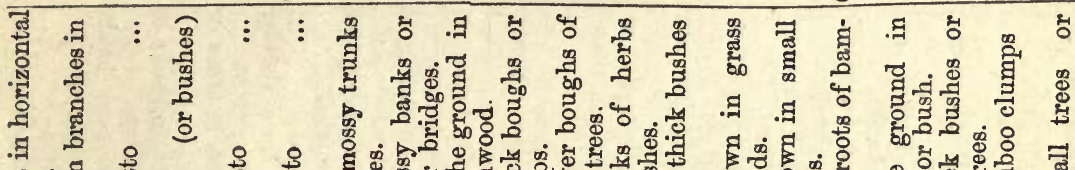
घ.

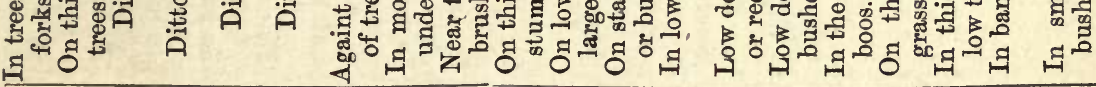

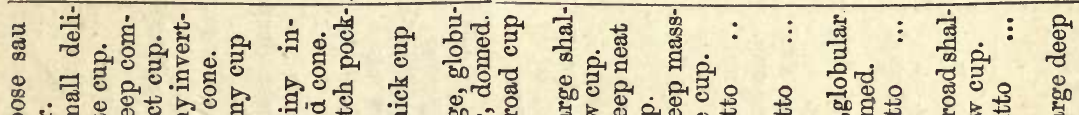

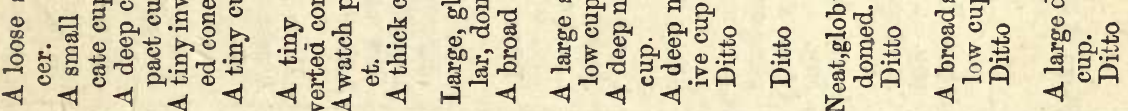

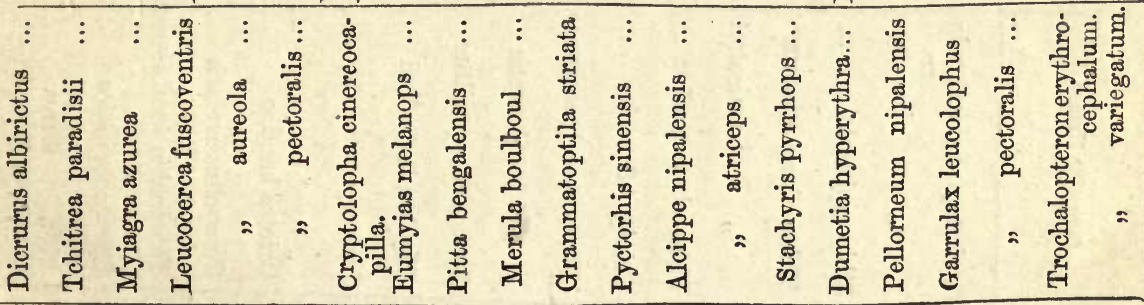

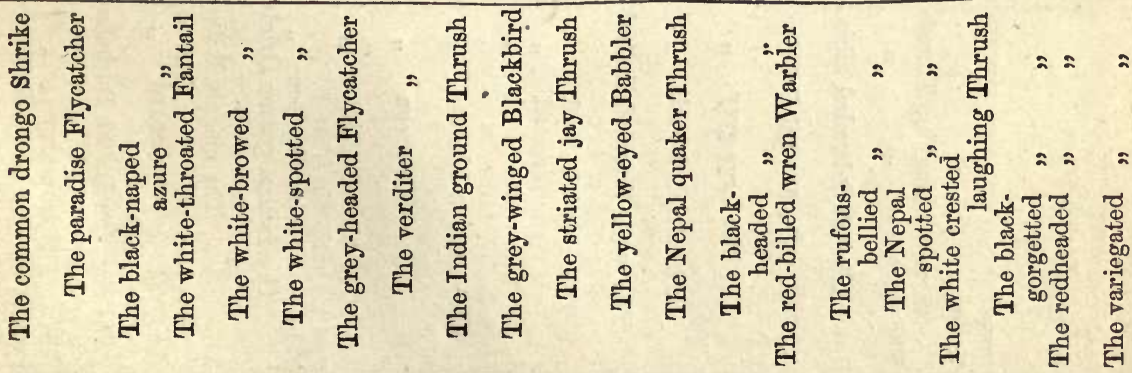

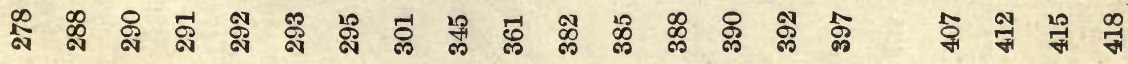




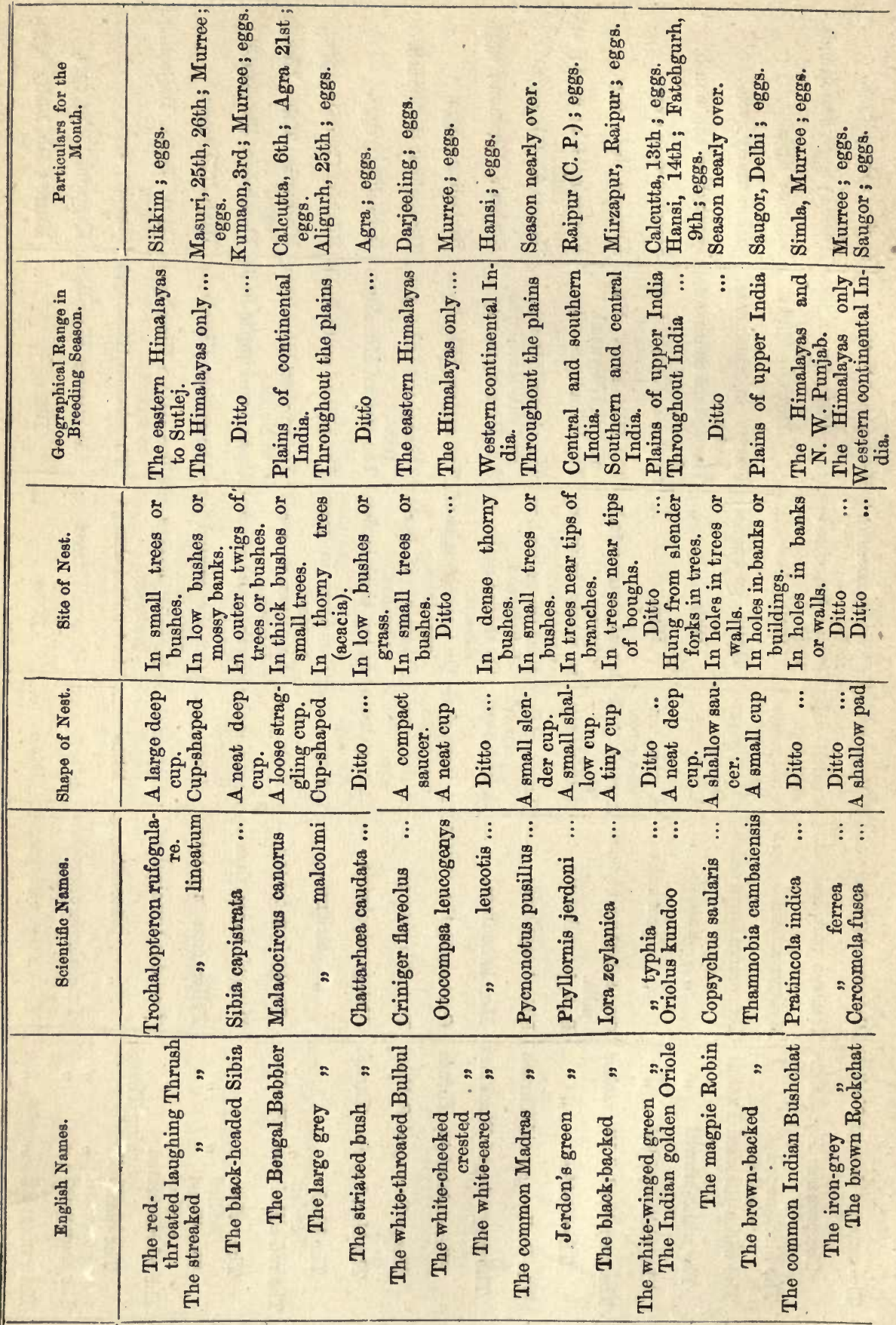

蕓 


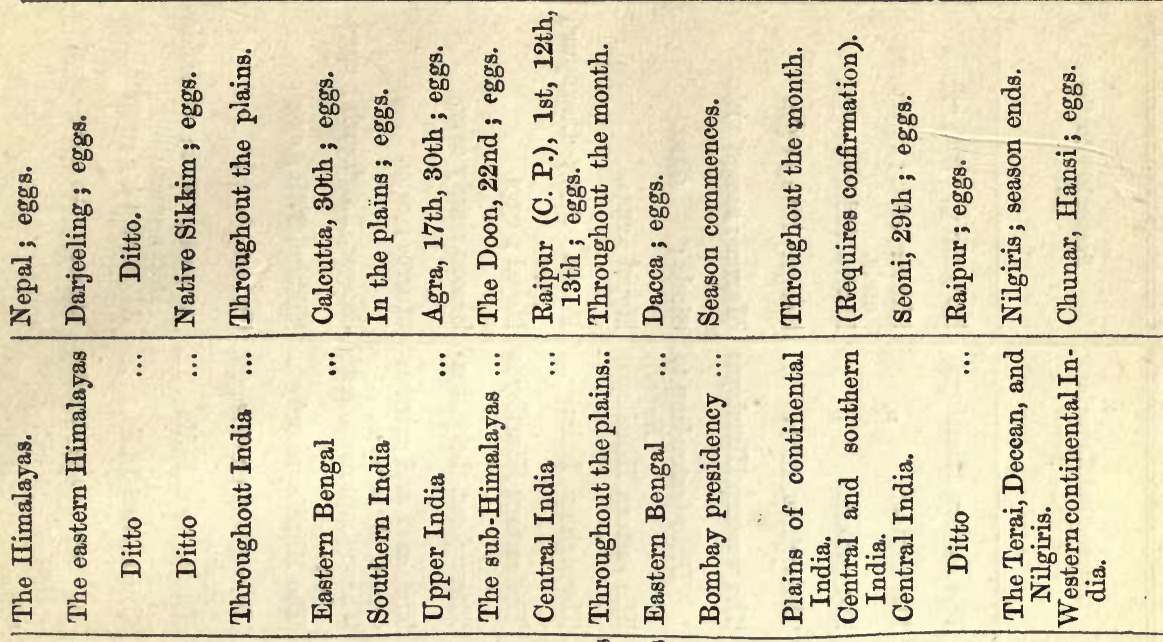
总 胭

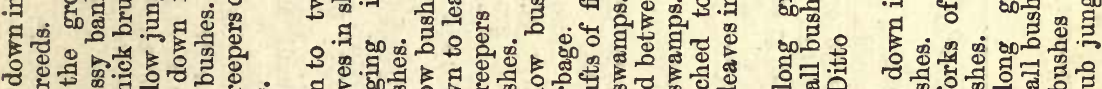

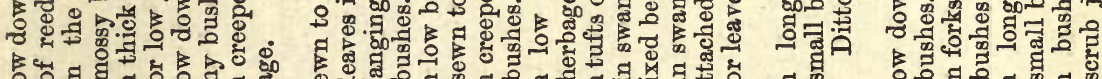

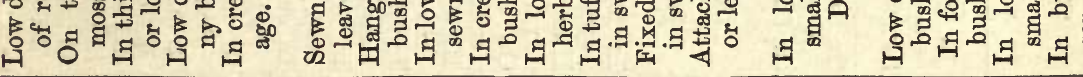

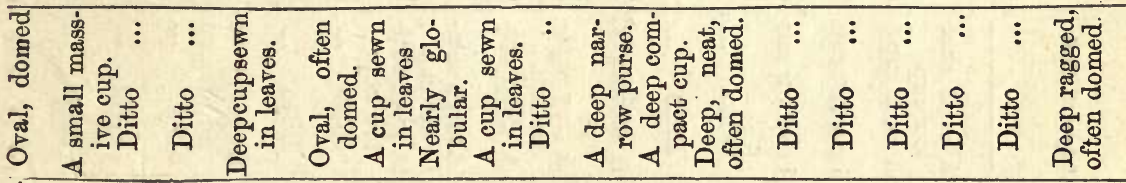

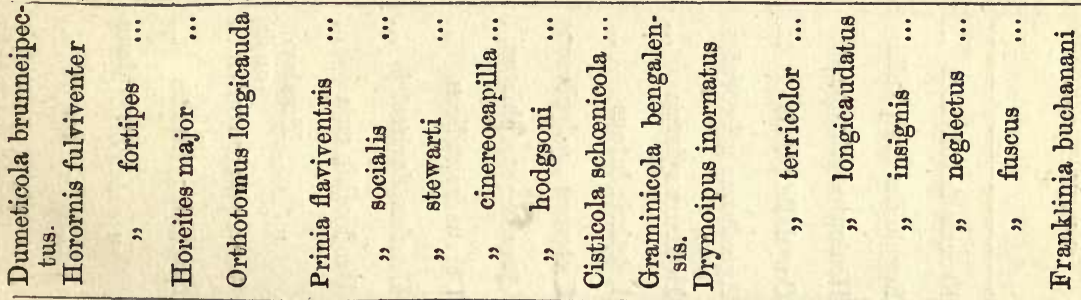

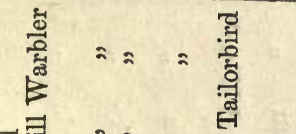

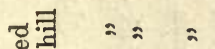

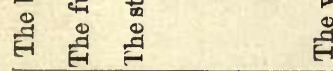

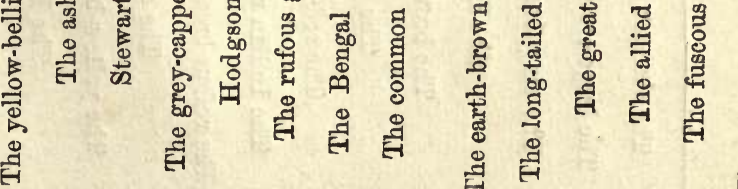
ษ

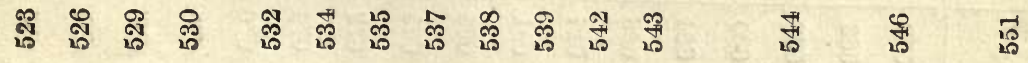




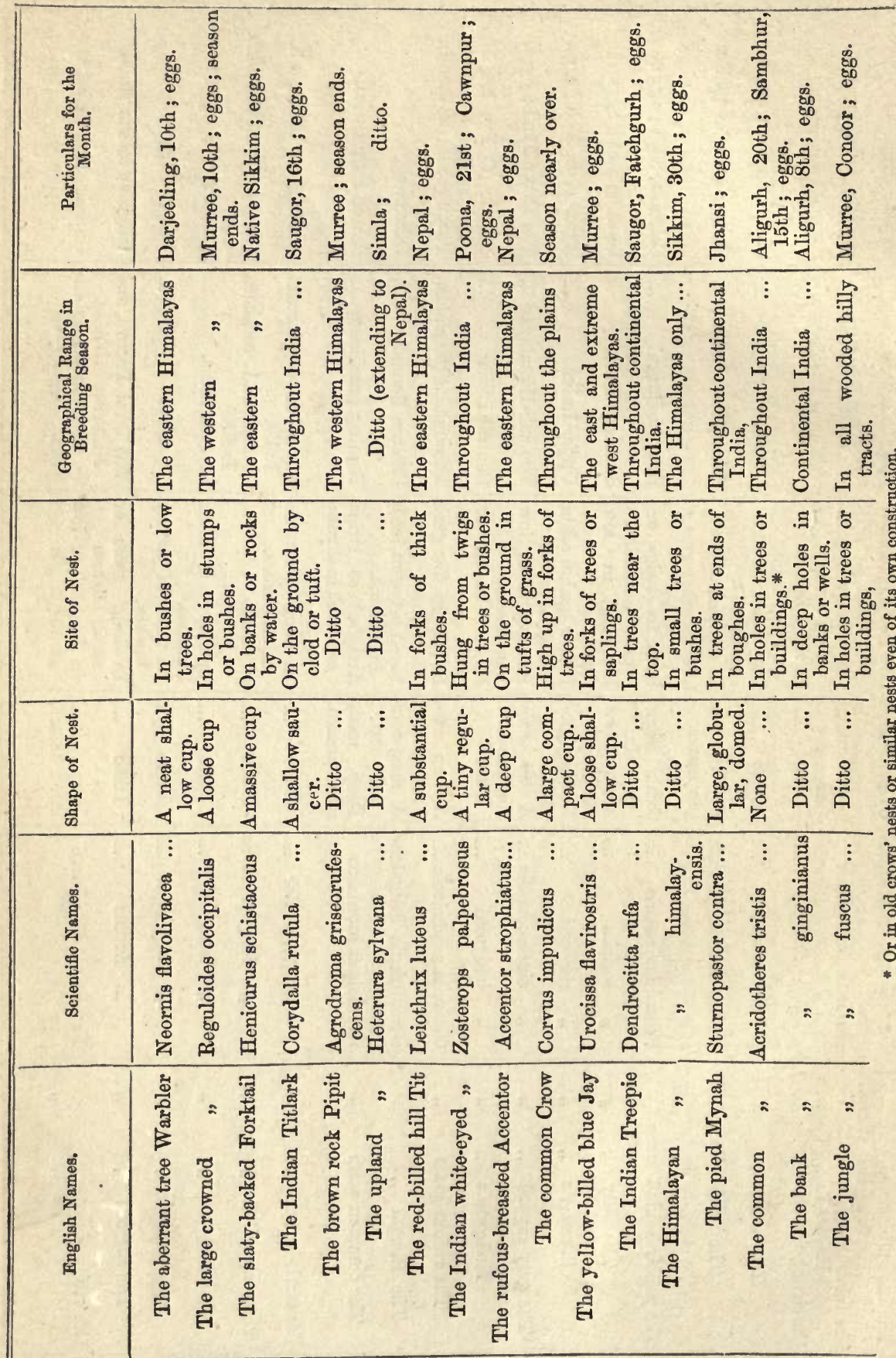

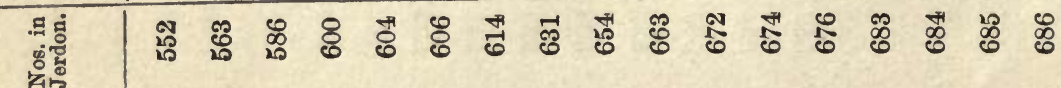




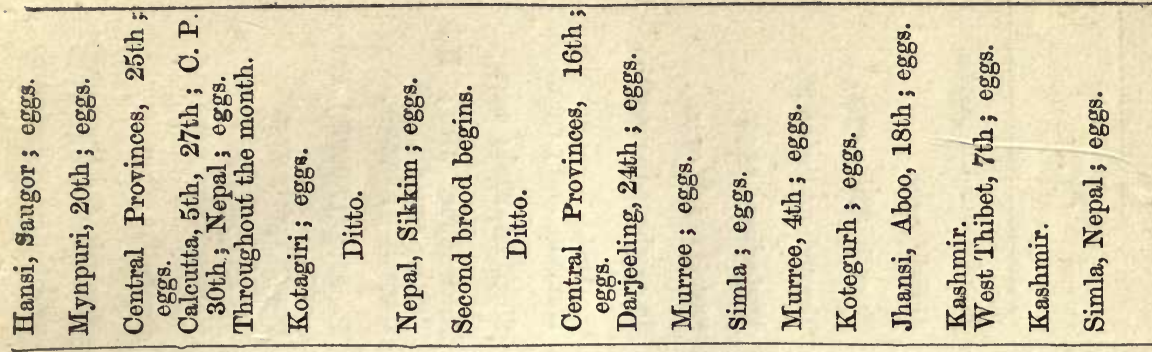

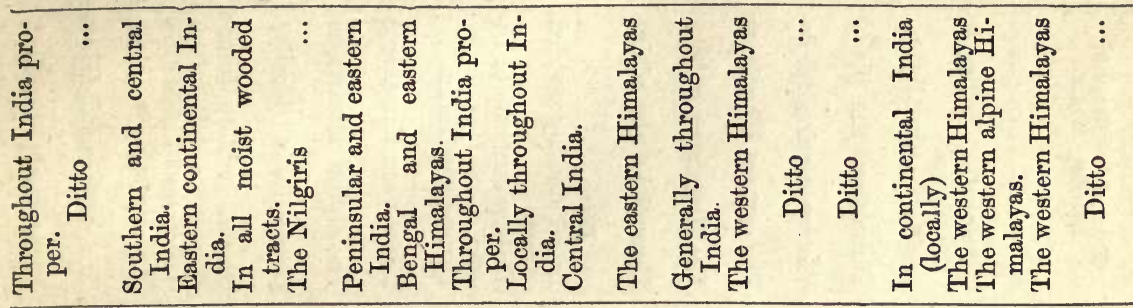

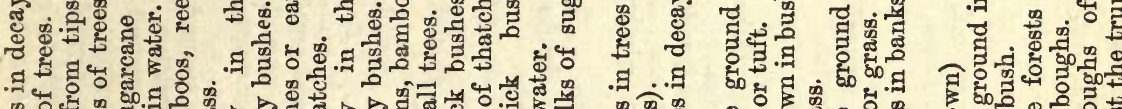
Q

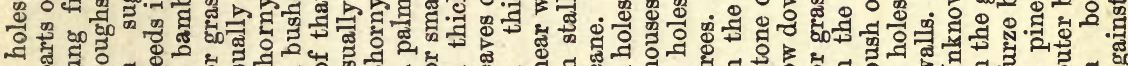

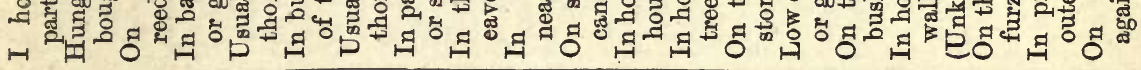

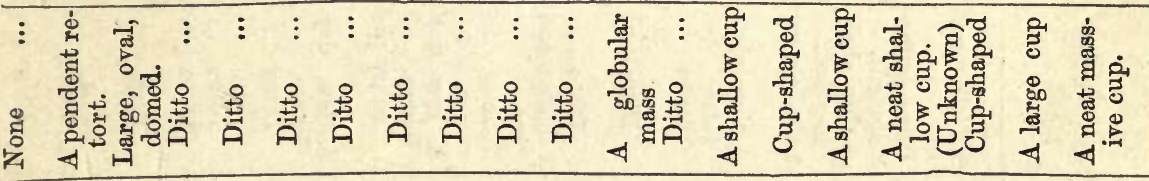

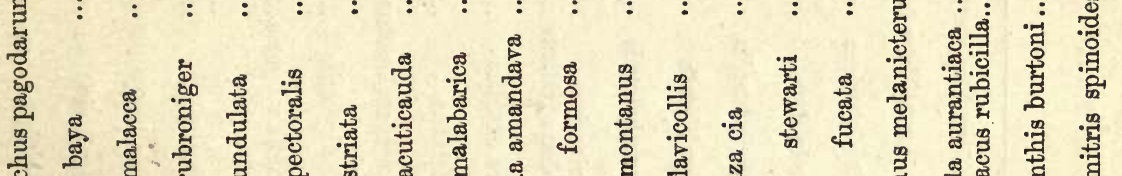

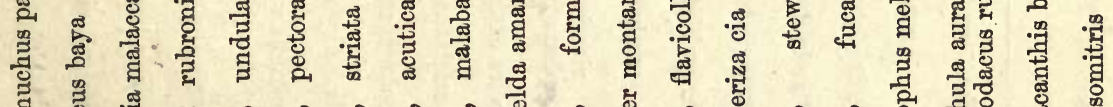

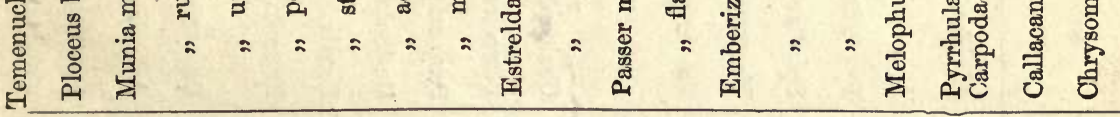

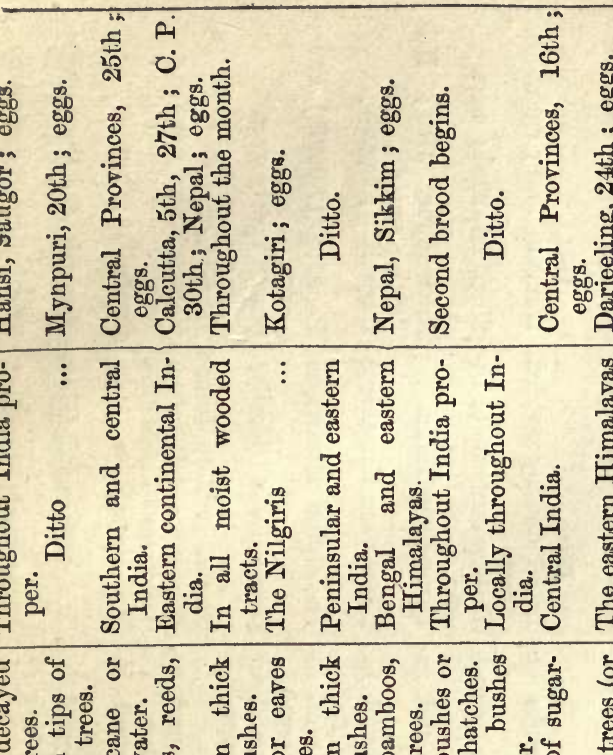

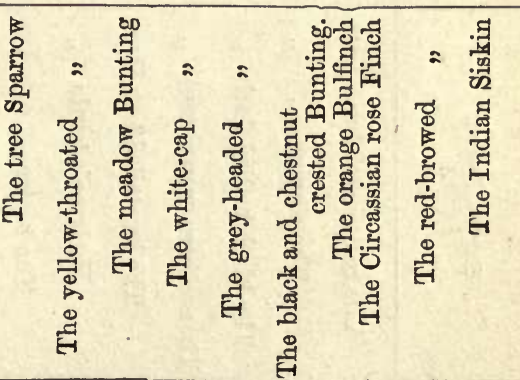

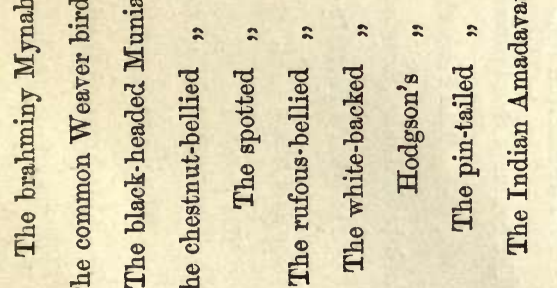

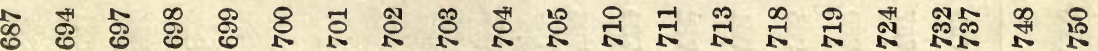




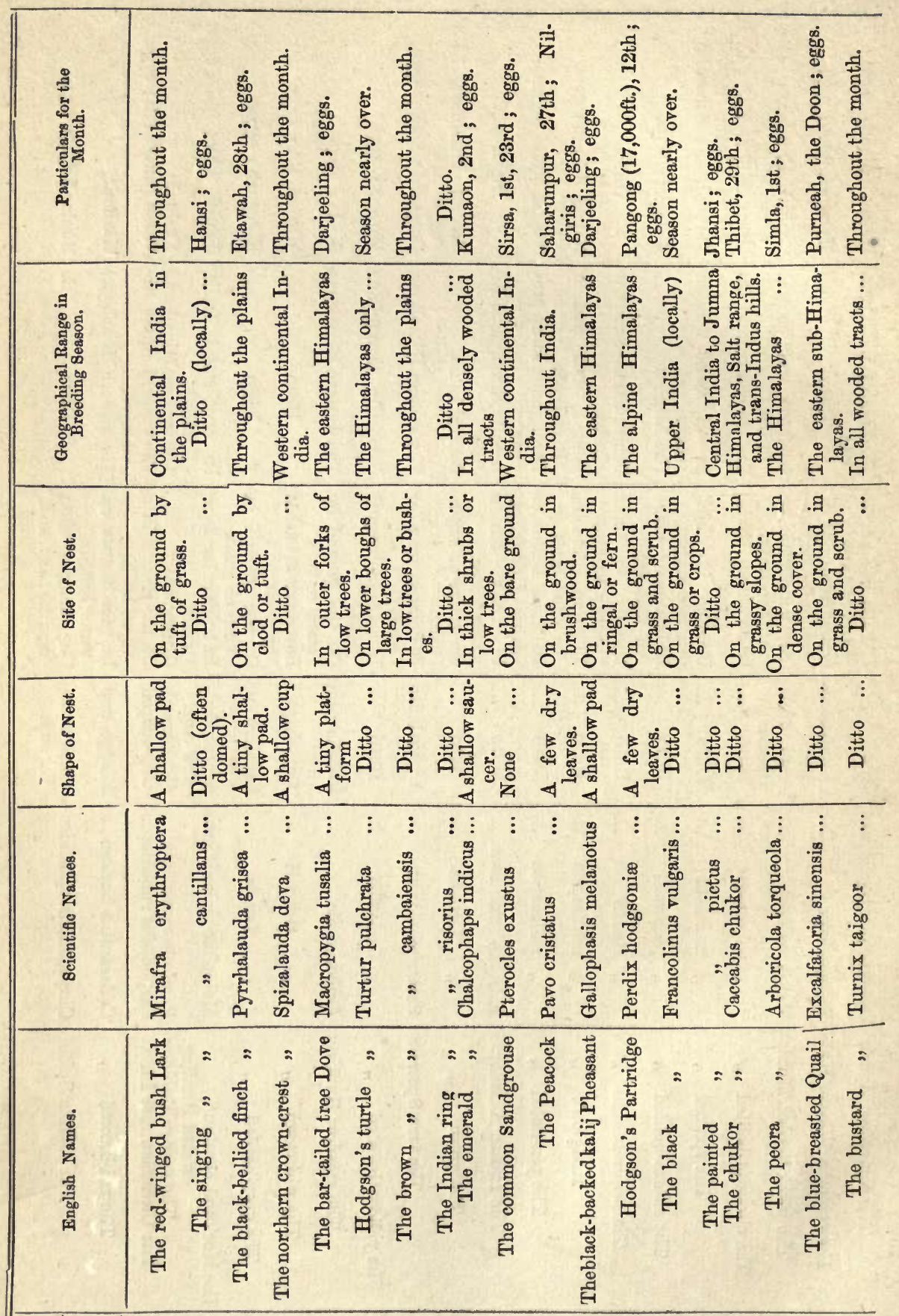

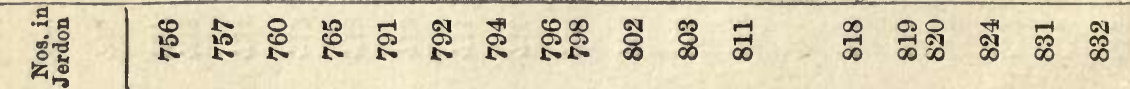




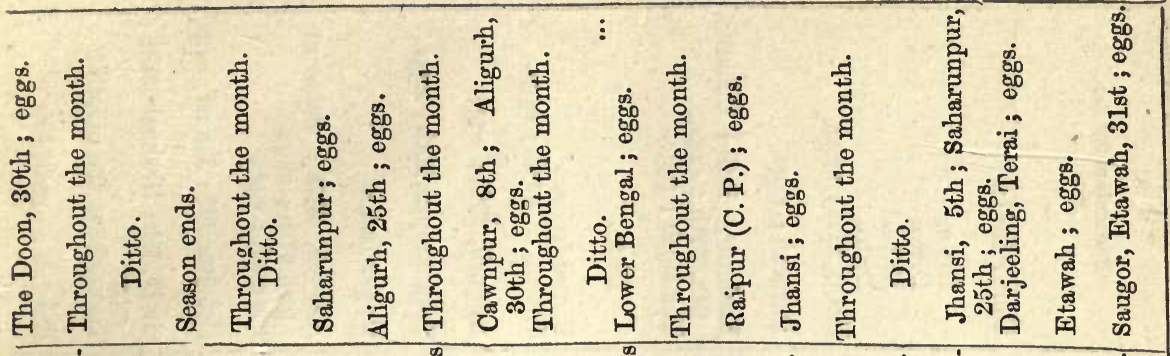

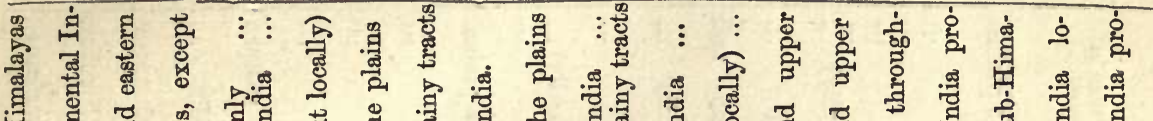

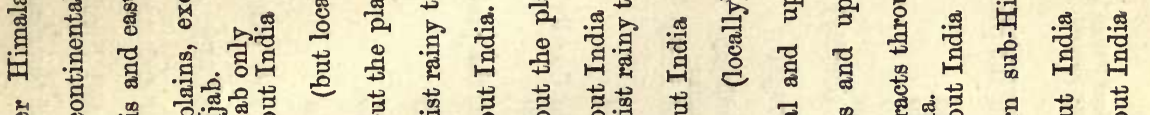
峁 \&

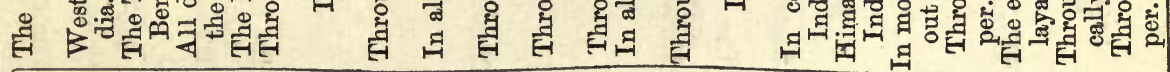

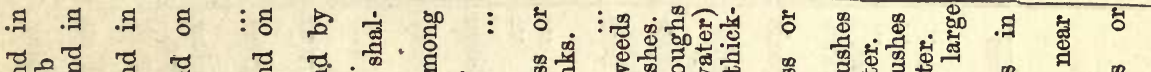

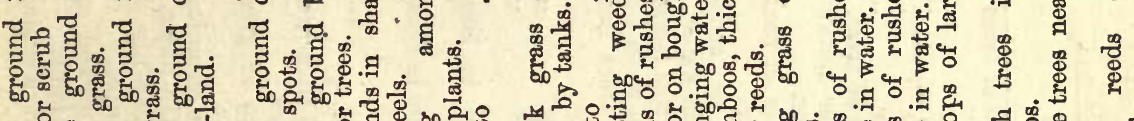
定。 g f

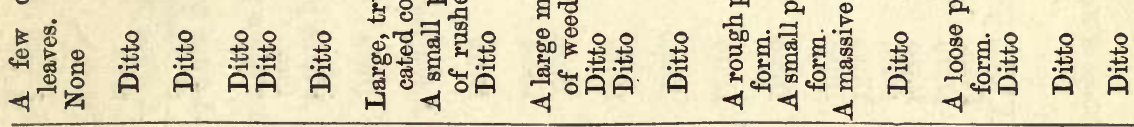

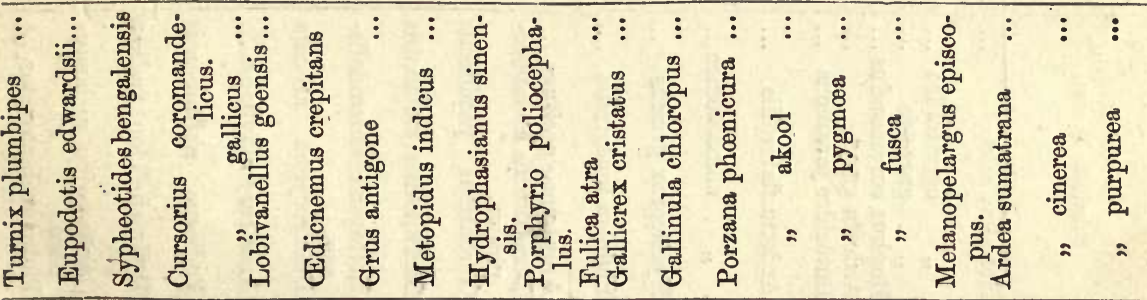

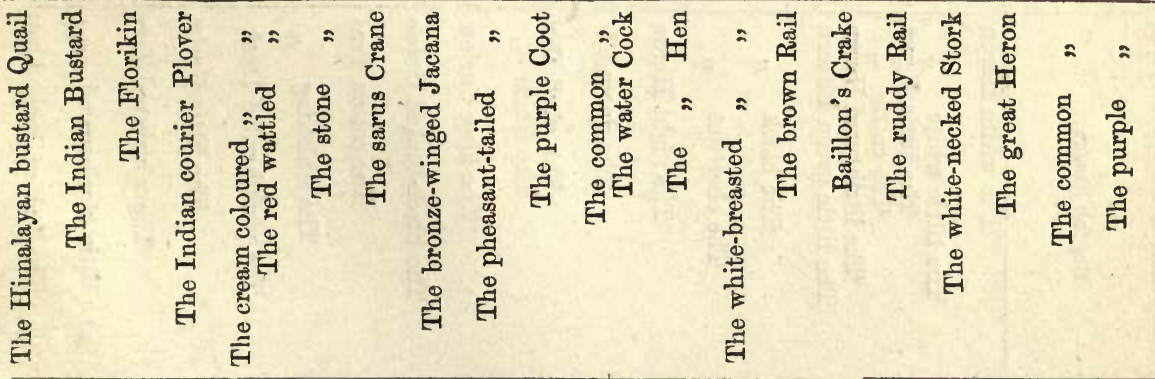

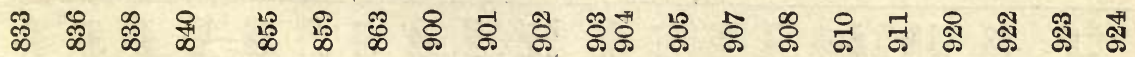




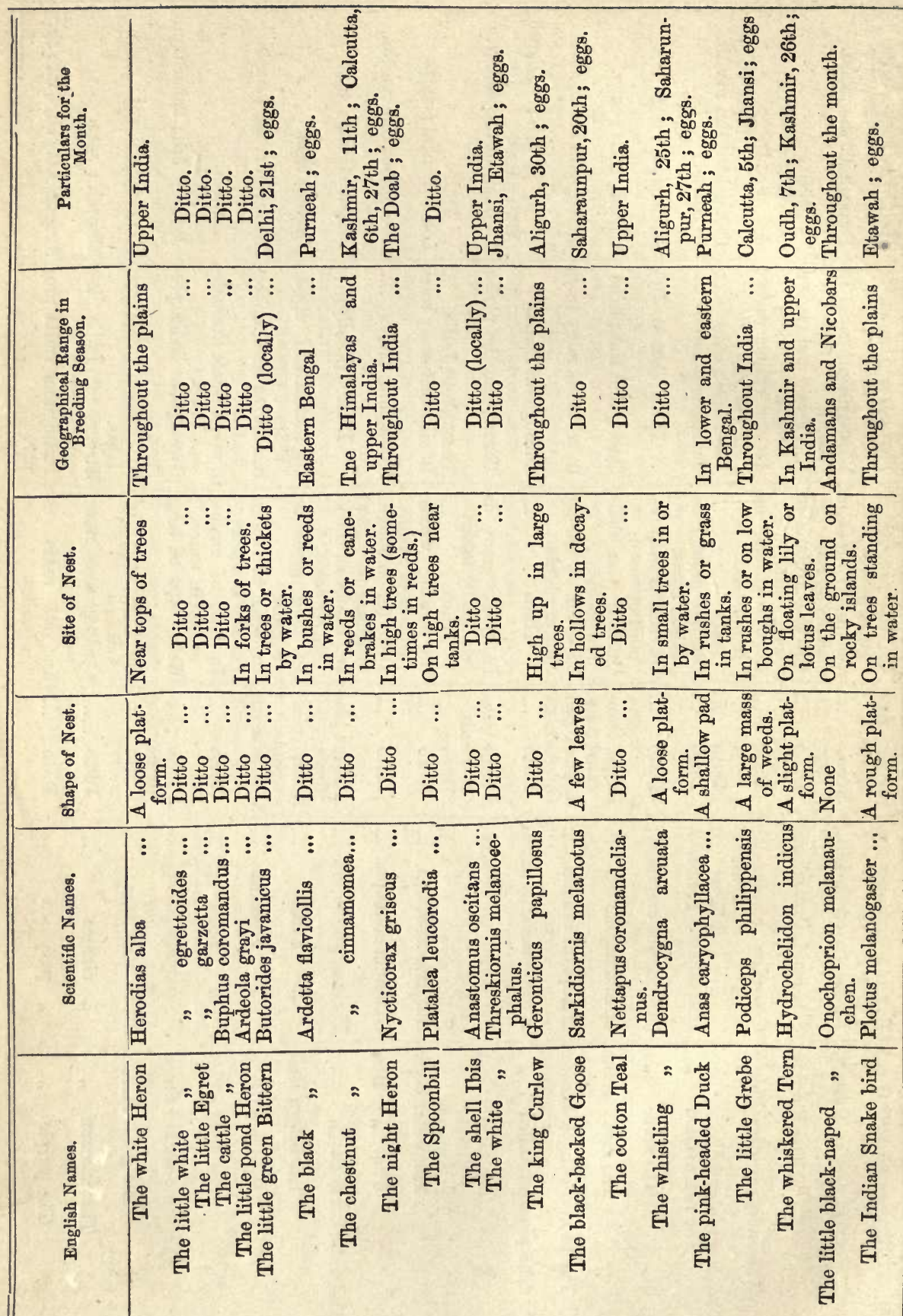

䨪 



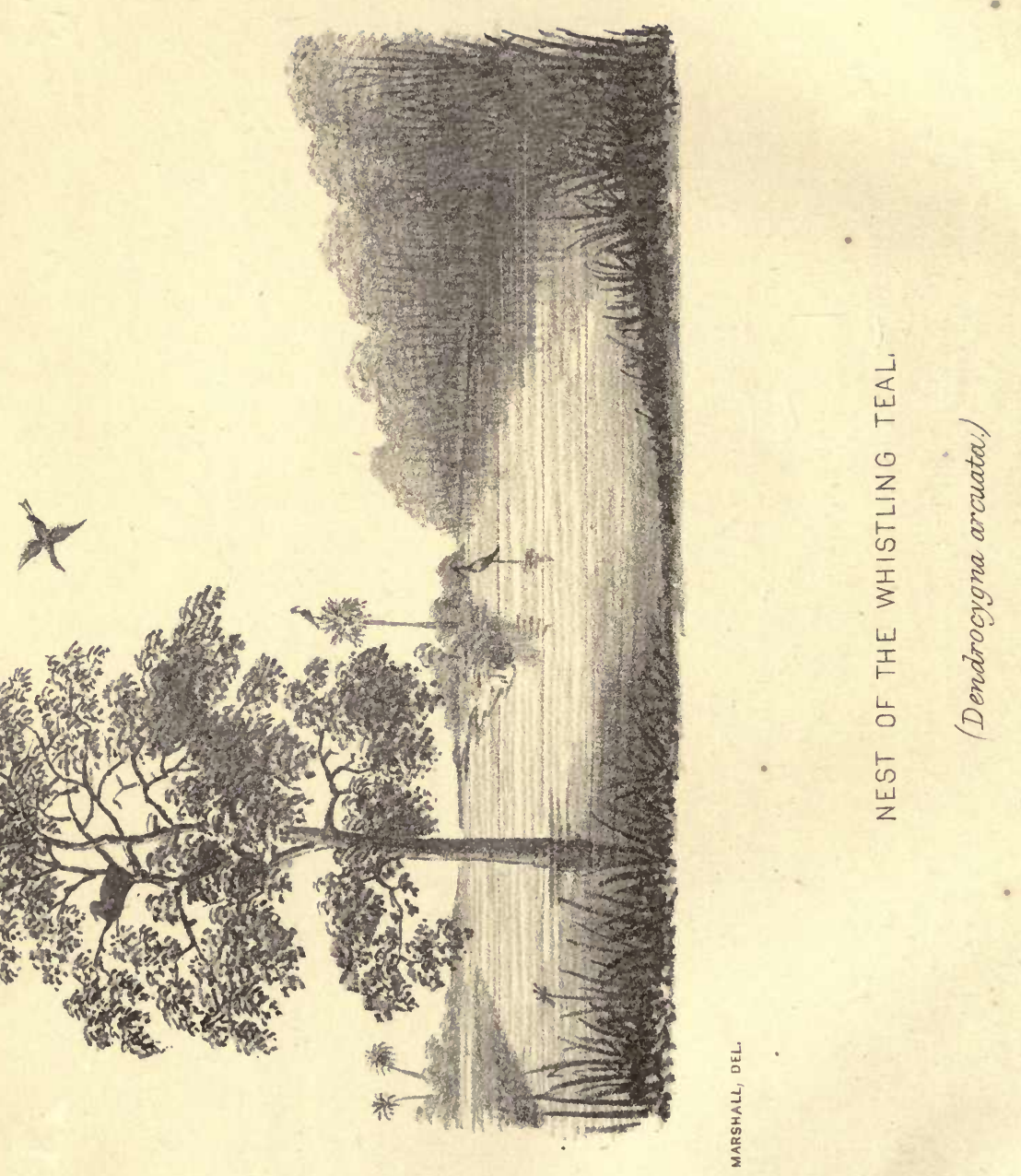




\section{AUGUST.}

IN this month the water-birds and small wren warblers are the principal breeders throughout the plains. The eggs of the rufous grass warbler, the white-eyed tit, the pin-tailed munia, the jungle bush quail, the bustard quail, and the little grebe may be taken.

In the Himalayas, the season is now nearly over. Eggs of the mosque swallow, the small minivet, the grey-winged blackbird, the red-headed and streaked laughing thrushes, the golden woodchat, the brown-breasted hill warbler, the red-billed hill tit, the yellow-billed blue jay, the chestnut-bellied and spotted munias, the meadow bunting, the Indian siskin, Hodgson's turtle dove, and the black partridge may still be found, though only a few stragglers are laying. Probably at the higher elevations many of the finches breed in this month, but their nests have not as yet been found.

In the PunJab, the black-winged kite is breeding, also the wire-tailed and mosque swallows; eggs of the sirkeer, the bay-backed shrike, the white-eyed bulbul, the striated reed babbler (second brood). The rufousfronted wren warbler, the large button quail, the big bustard, Blythe's water hen, and most of the resident water-birds may still be taken. The streaked wren warbler is building for its second brood.

In the North-West Provinces, the wire-tailed and mosque swallows, the common swifts, the pied crested cuckoos, coucals, sirkeers rufousbacked and bay-backed shrikes, large grey cuckoo shrikes, white-browed fantails, babblers, reed babblers, wren warblers, mynahs, striated and common weaver birds, black-bellied finch larks, peafowl and almost all the resident water-birds, waders and swimmers, except the terns and plovers, have eggs throughout the month; while the grass babbler, streaked wren warbler, black-throated weaver bird, painted snipe, and black-necked stork commence building towards the end of the month.

In BENGAL, the characteristic breeders are the yellow-bellied wren warbler, the tailor bird, the Bengal grass warbler, the chestnut-bellied munia, the peafowl, jacanas, rails and coots and bitterns, which almost all have eggs, besides, many of those which breed at this season in other parts. The grass babbler and black-throated weaver bird begin to build in this month. 
In Central India, eggs of the cliff swallow, Nilgiri nightjar, purple honey sucker, blackcap sbrike, pied cuckoo shrike, large grey cuckoo shrike, small minivet, white-browed fantail, ground thrush, rufous-bellied wren warbler, green bulbuls, ioras, the great and allied wren warblers, Sykes' warbler, the chestnut-bellied and spotted munias, the Indian amadavat, the crested bunting, the painted partridge, the lesser button quail, jacanas, coots, rails, king curlew, large whistling teal, and lesser cormorant may be taken during the month. The likh florikin and the painted snipe commence pairing and building torvards the end of the month.

In SoutHerN INDIA, the honey suckers have eggs, also the ashy wren warbler, the common wren warbler, the brahminy mynah, the spotted white-backed and pin-tailed munias, the Indian amadavat, the crown-crest lark, the rain quail, bush quail, and bustard quail : probably the eggs of many other species also may be found. The white-browed bush bulbul and the Nilgiri skylark are building towards the end of the month for their second brood. 


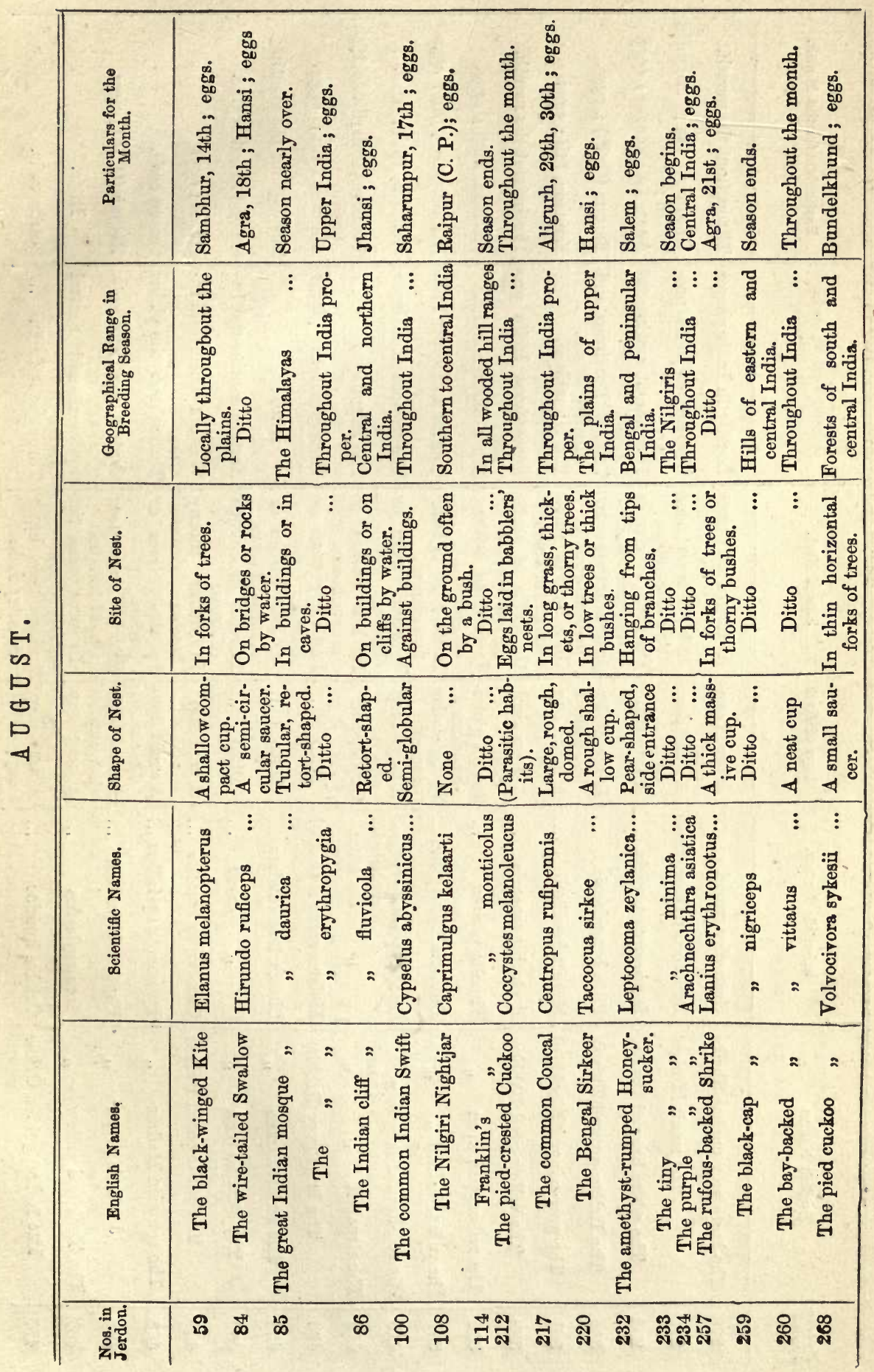




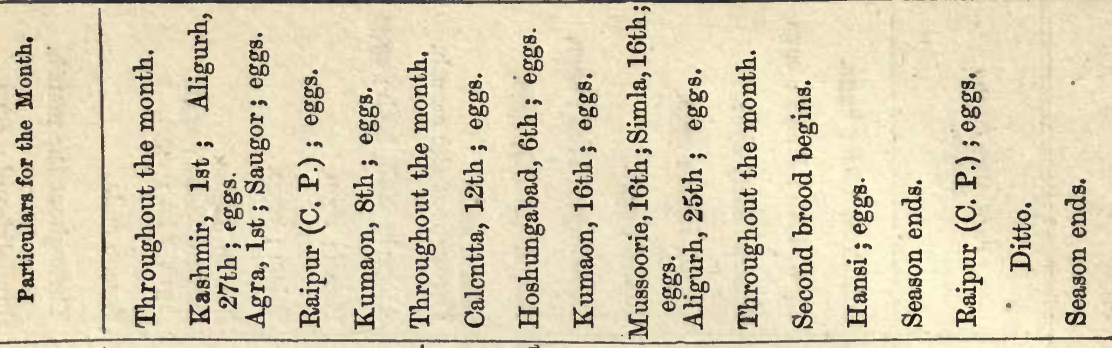

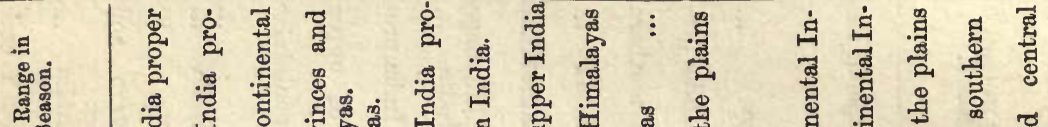

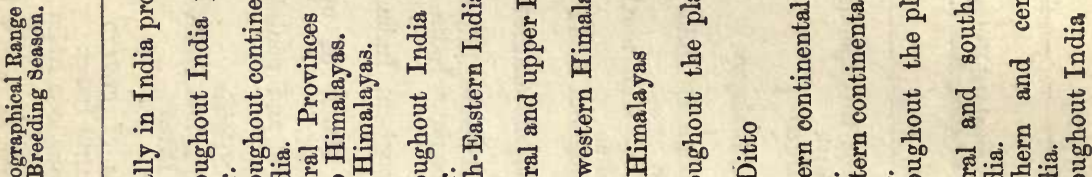

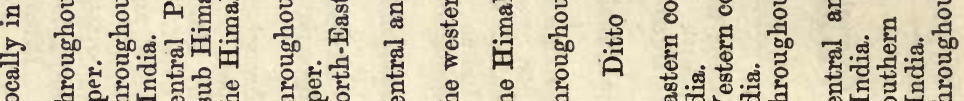

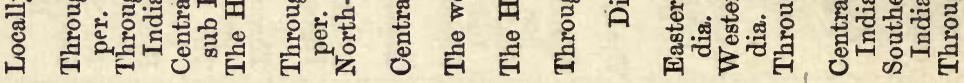

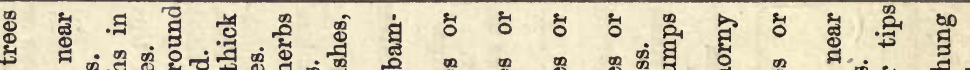

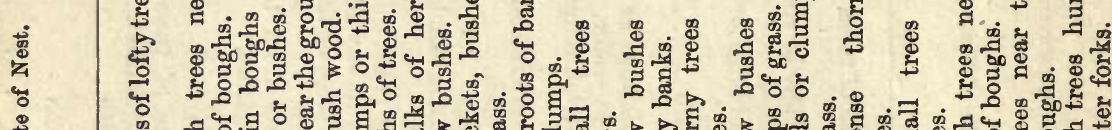
站 $\quad$ on

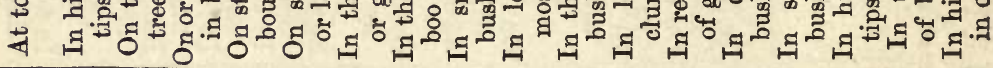

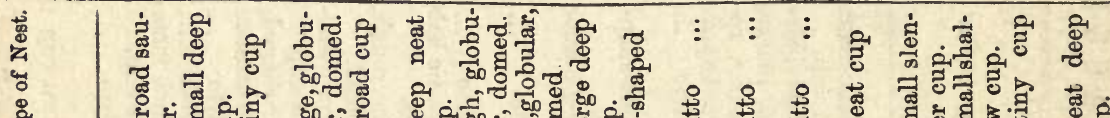

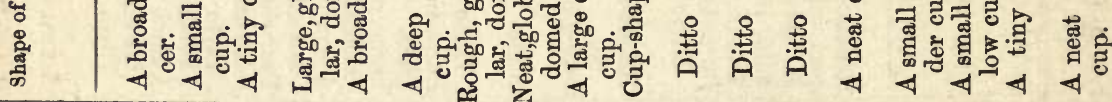

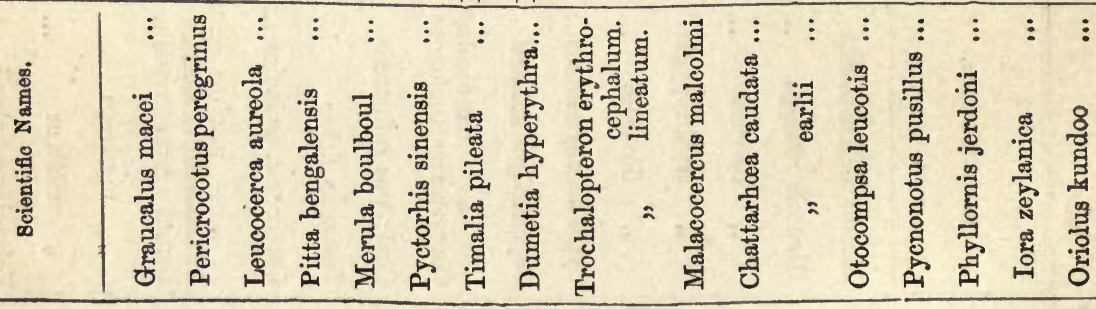

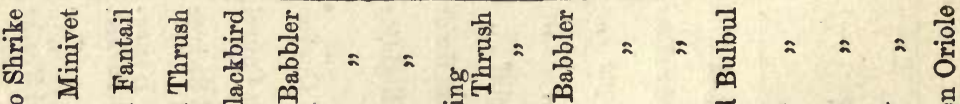

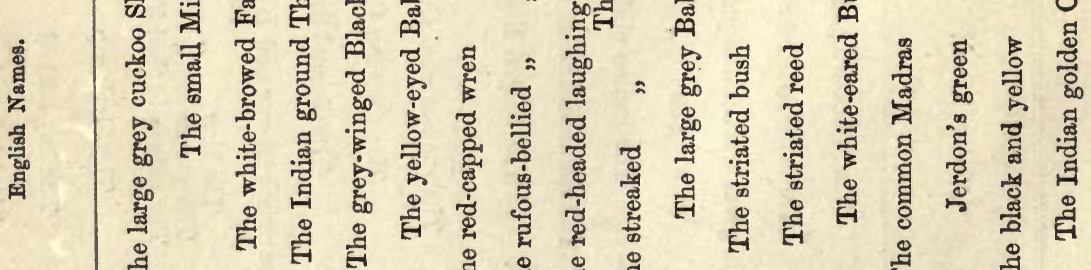

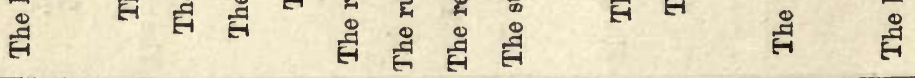

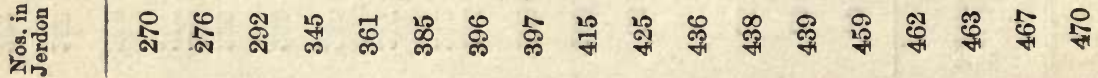




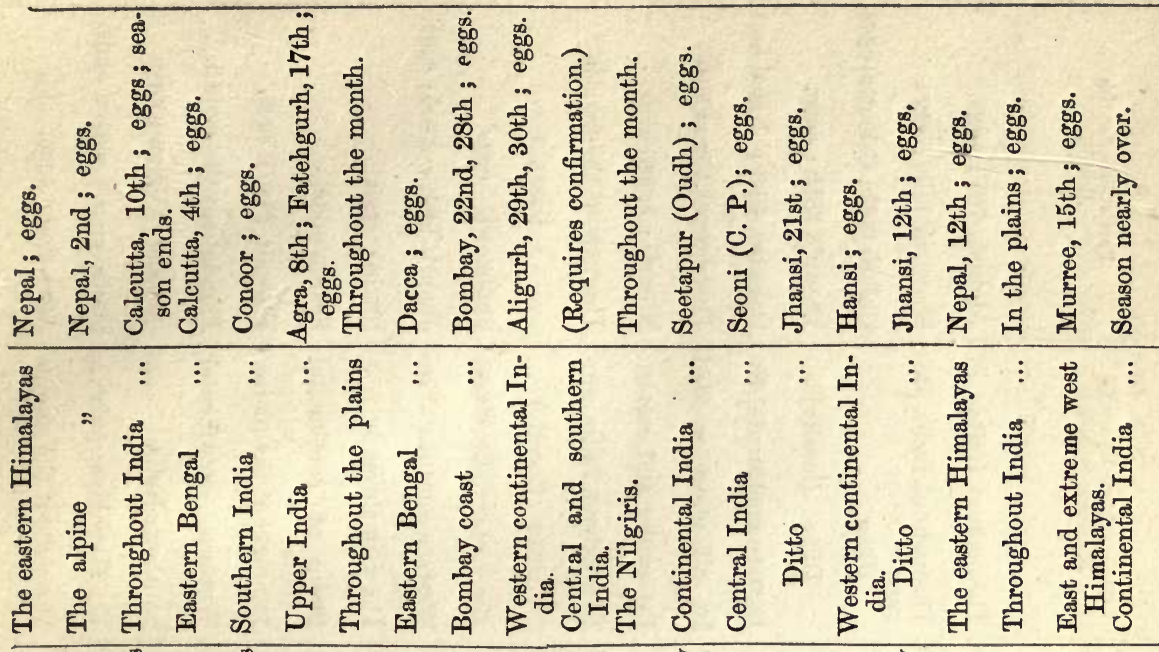

फ

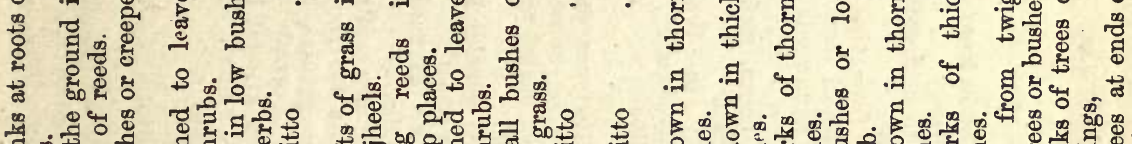

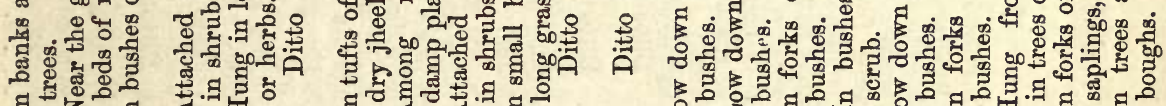

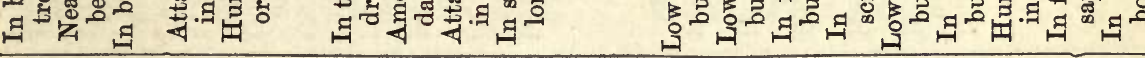
造 总

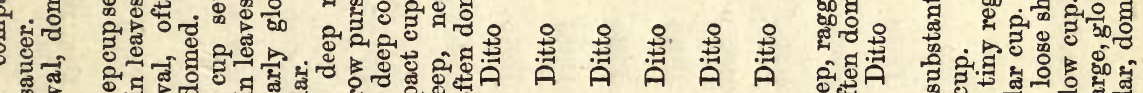

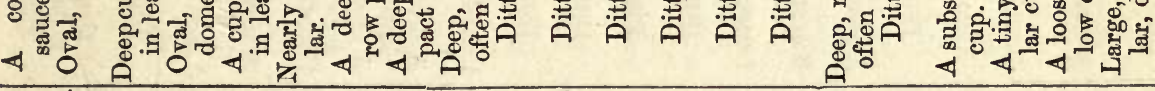

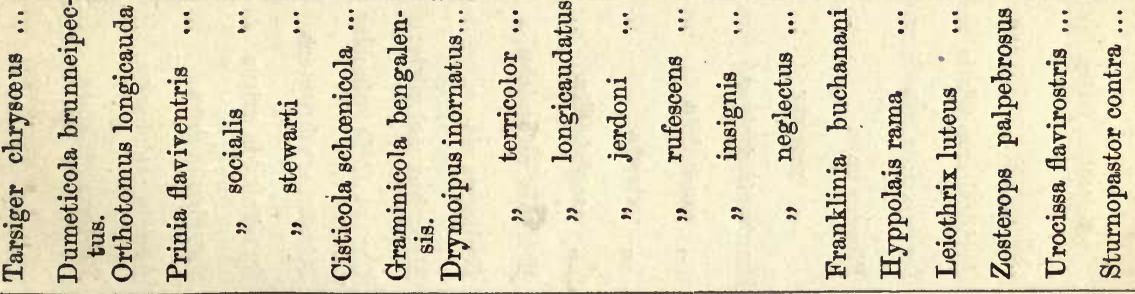

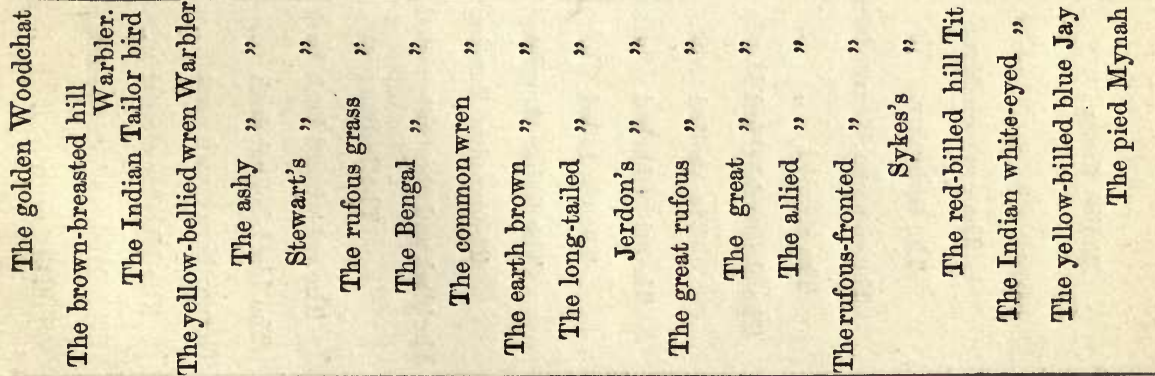

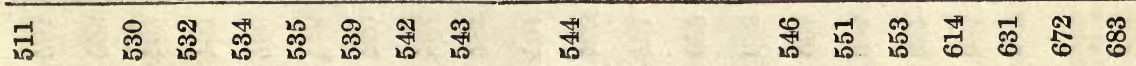




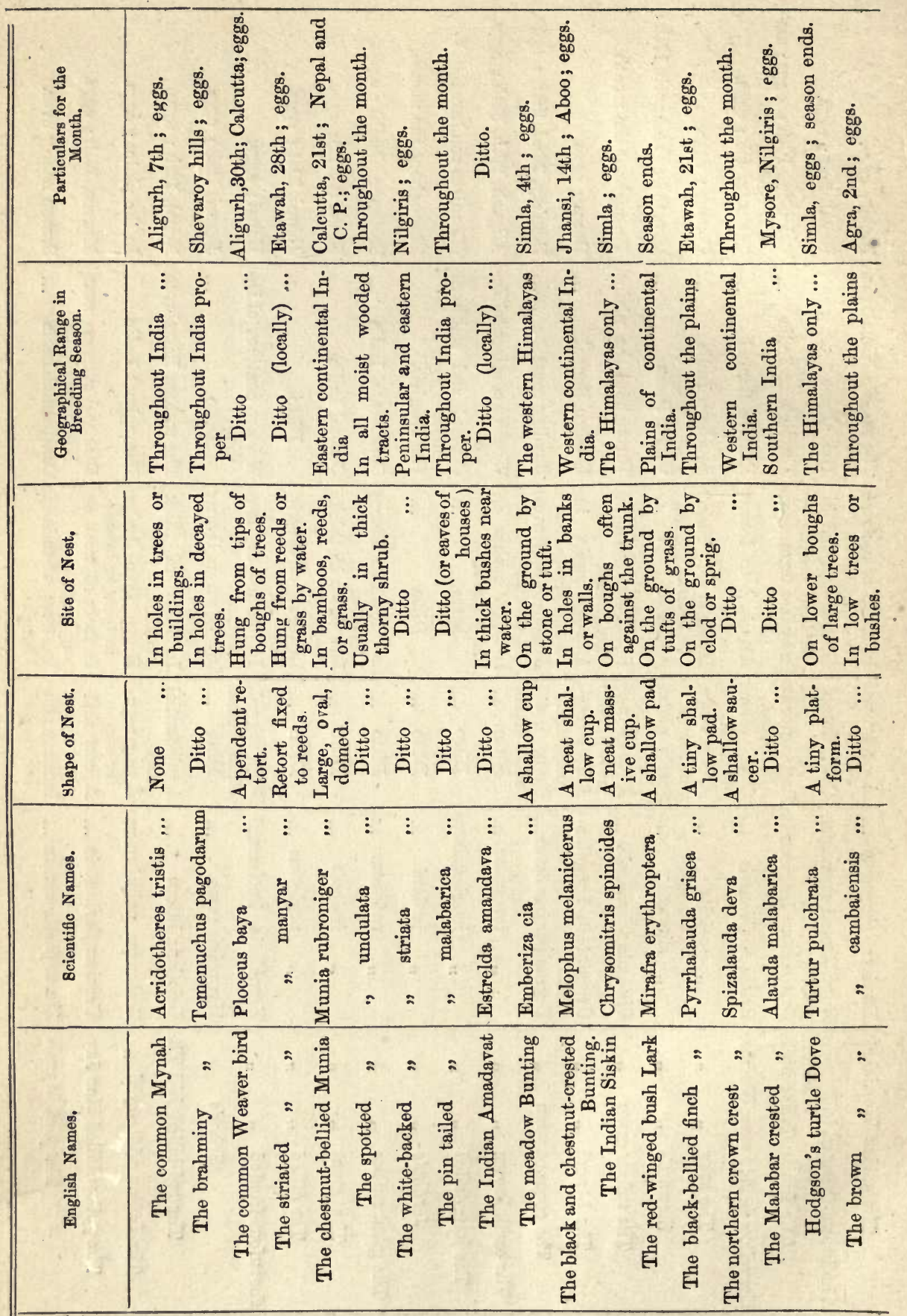

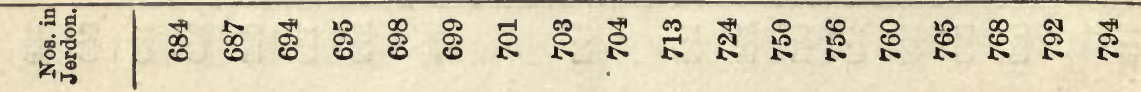




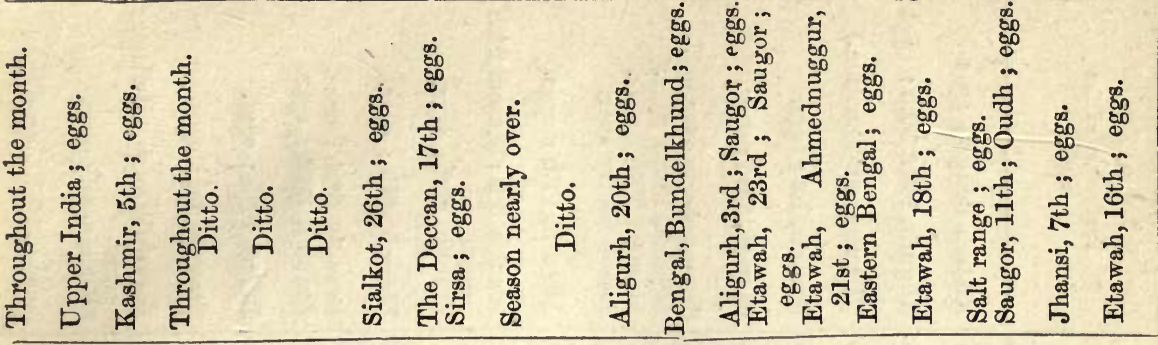
营

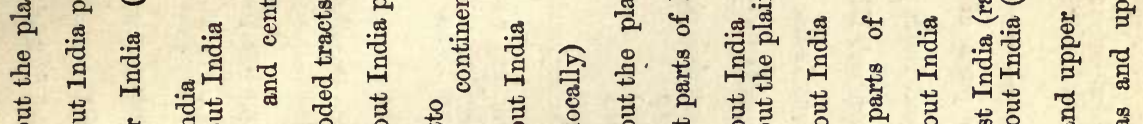

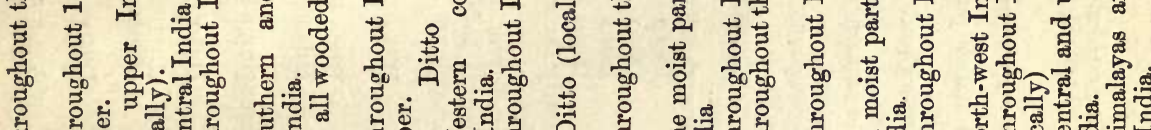

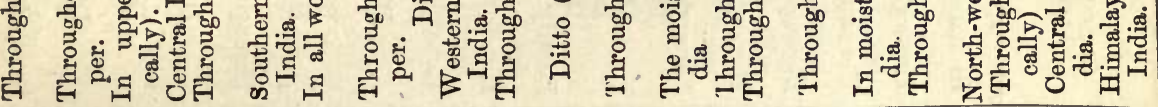

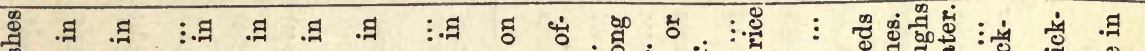
击

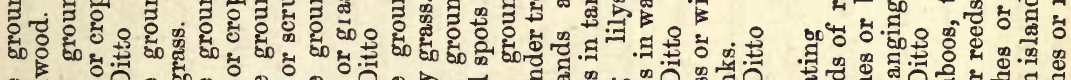

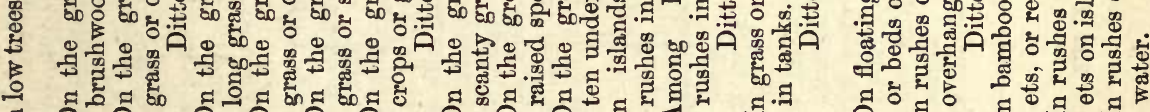

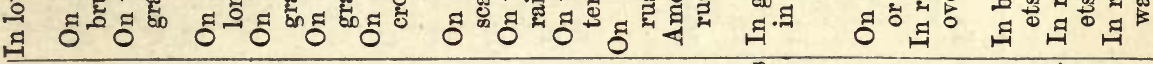
离

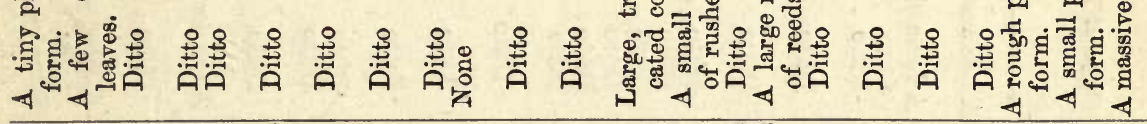

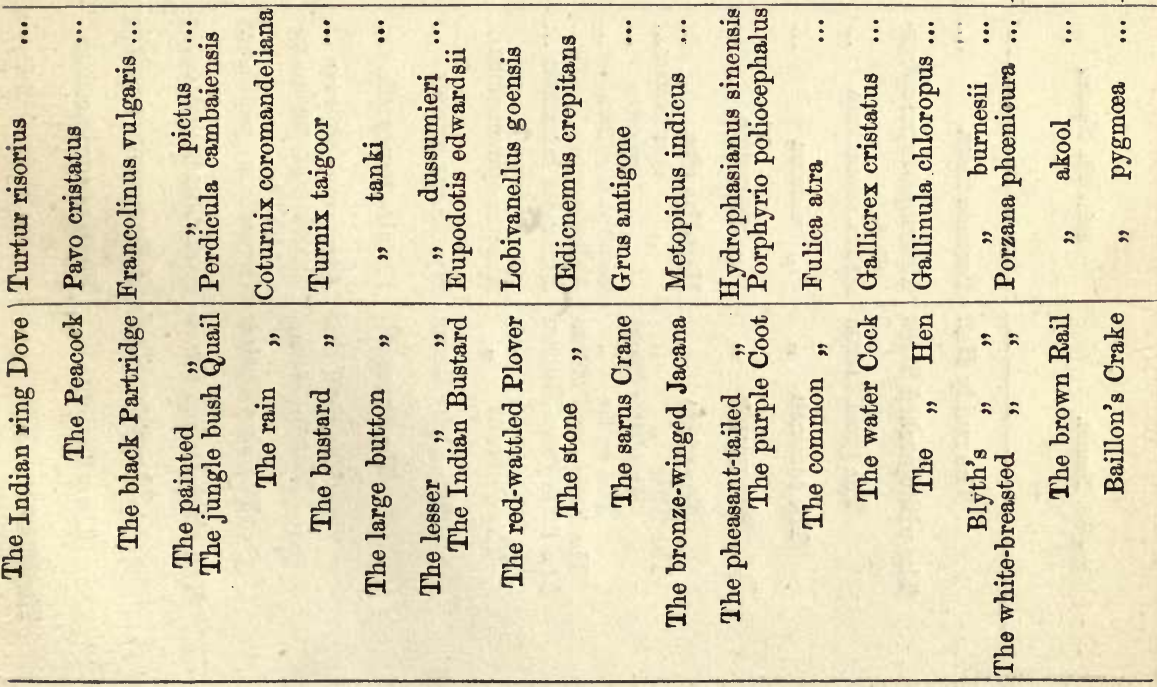

\& 


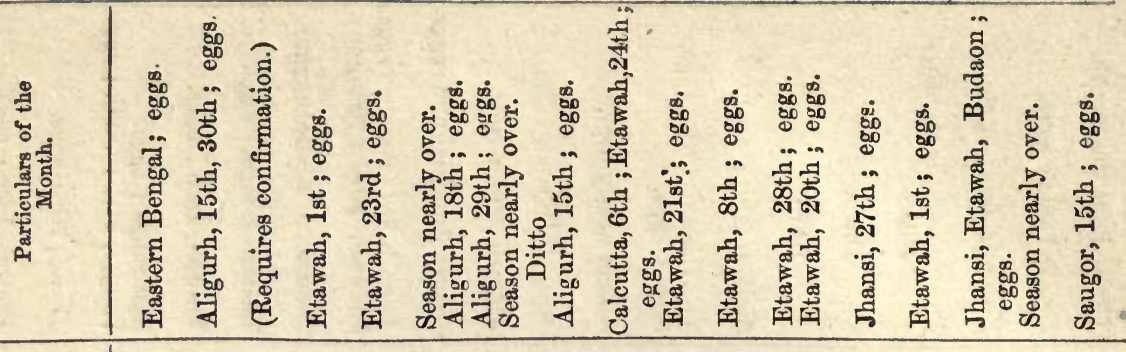

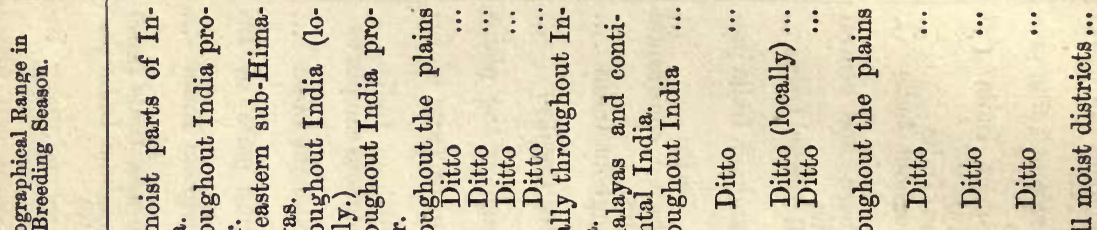
兽

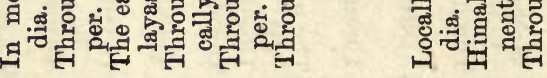
सै ฐ

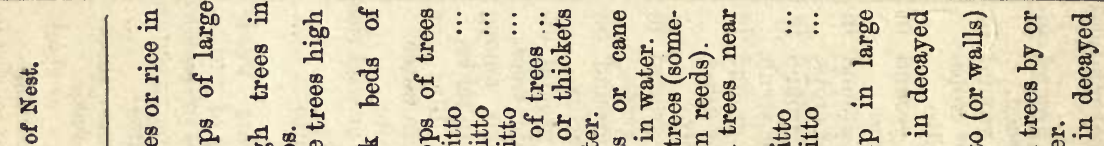

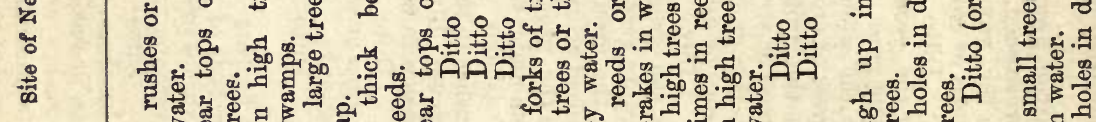

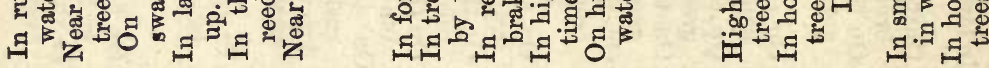

\begin{tabular}{|c|c|c|c|c|c|c|c|c|c|c|c|c|c|c|c|}
\hline 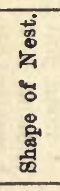 & 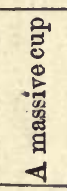 & 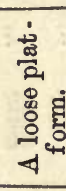 & : & 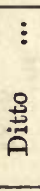 & 芶 & 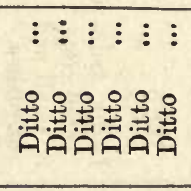 & 总 & 总 & $\stackrel{8}{\stackrel{8}{*}}$ & 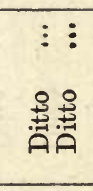 & 量 & 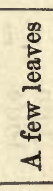 & 融 & $\begin{array}{l}\text { क् } \\
0 \\
0 \\
0 \\
0 \\
\\
\end{array}$ & \\
\hline 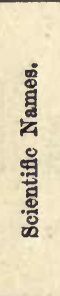 & 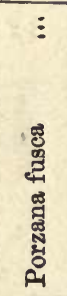 & 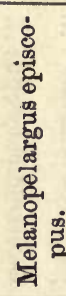 & 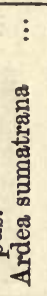 & 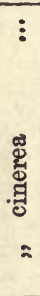 & 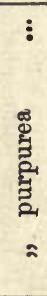 & 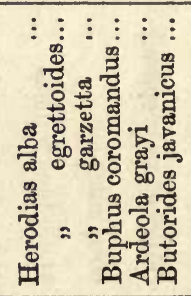 & 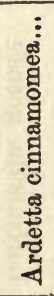 & 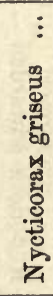 & 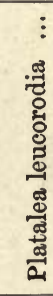 & 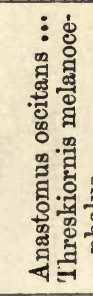 & 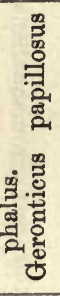 & 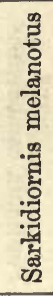 & 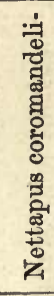 & 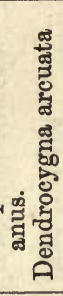 & 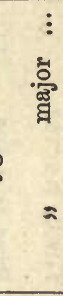 \\
\hline 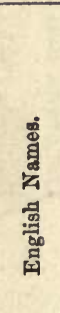 & 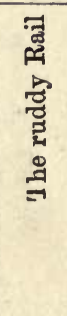 & 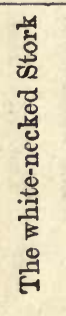 & 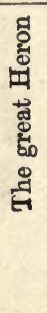 & 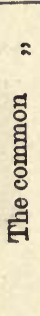 & $\begin{array}{l}\text { on } \\
\text { a } \\
0 \\
0 \\
0\end{array}$ & 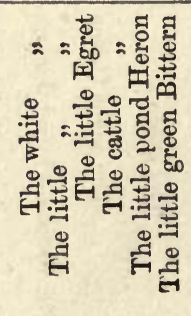 & 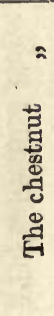 & 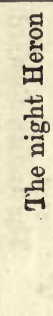 & 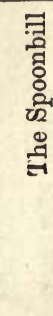 & 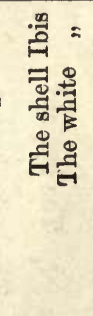 & 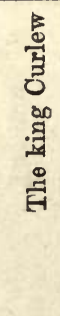 & 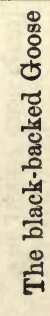 & 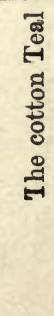 & 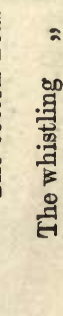 & \\
\hline
\end{tabular}

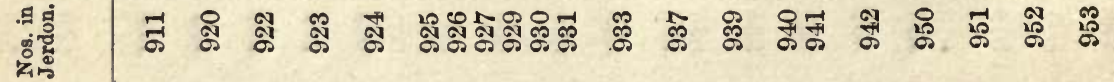




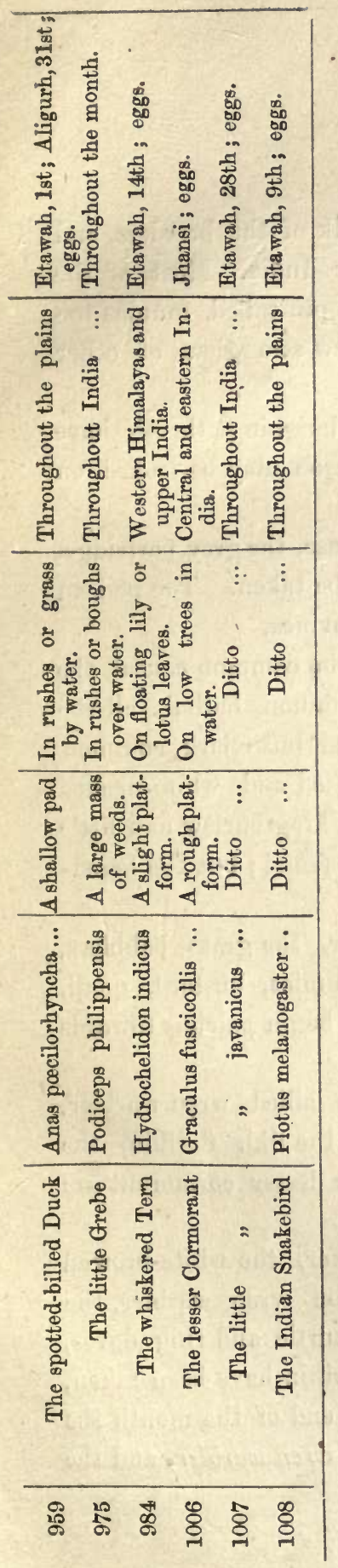




\section{SEPTEMBER.}

IN this month the water-birds form the bulk of the breeders, and with them the season practically ends in upper India. Most of the wren warblers and the rufous grass warbler and pin-tailed munias too are breeding everywhere in the plains, and a few stragglers of other families and genera.

In the Hrmalayas, eggs of the streaked laughing thrush have been taken, but no others are recorded, and the season may be looked on as practically over.

In the Punjab, eggs of the common sandgrouse, the grey partridge, and probably also those of the likh florikin may be taken. The pelican ibis too begins to lay in the eastern part of the province.

In the North-West Provinces, eggs of the common coucal, the yellow-eyed babbler, the grass babbler, the common bulbul, all the wren warblers and weaver birds, the red-winged bush lark, common sandgrouse, the peafowl, painted snipe, black-necked and white-necked storks, purple herons, chestisut bitterns, spoonbills, king curlew and little grebes, and possibly of several other kinds may be found ; but the breeding season is now perceptibly on the decline.

In BENGAL, the amethyst-rumped boneysucker, the grass babblers, the black-throated weaver birds, chestnut-bellied munias, bustard, quail, and painted snipe have eggs, while the grass owls begin pairing towards the end of the month.

In Central India, the common bulbul, the allied wren warbler, the common sandgrouse, the painted partridge, the likh florikin, the painted snipe, the bronze-winged jacana, and the lesser cormorant are known to have eggs.

In SouTh Indra, eggs of the tiny honeysucker, the white-browed bush bulbul, the ashy wren warbler, the common wren warbler, the pin-tailed munia, the Malabar-crested lark, the turtle and ring doves, the red-billed bush quail, the rain quail, the likh florikin have been taken, and probably many other kinds lay. Towards the end of the month the white-headed babbler, the jungle babbler, Adams's wren warbler, and the grey jungle fowl commence to pair and build. 


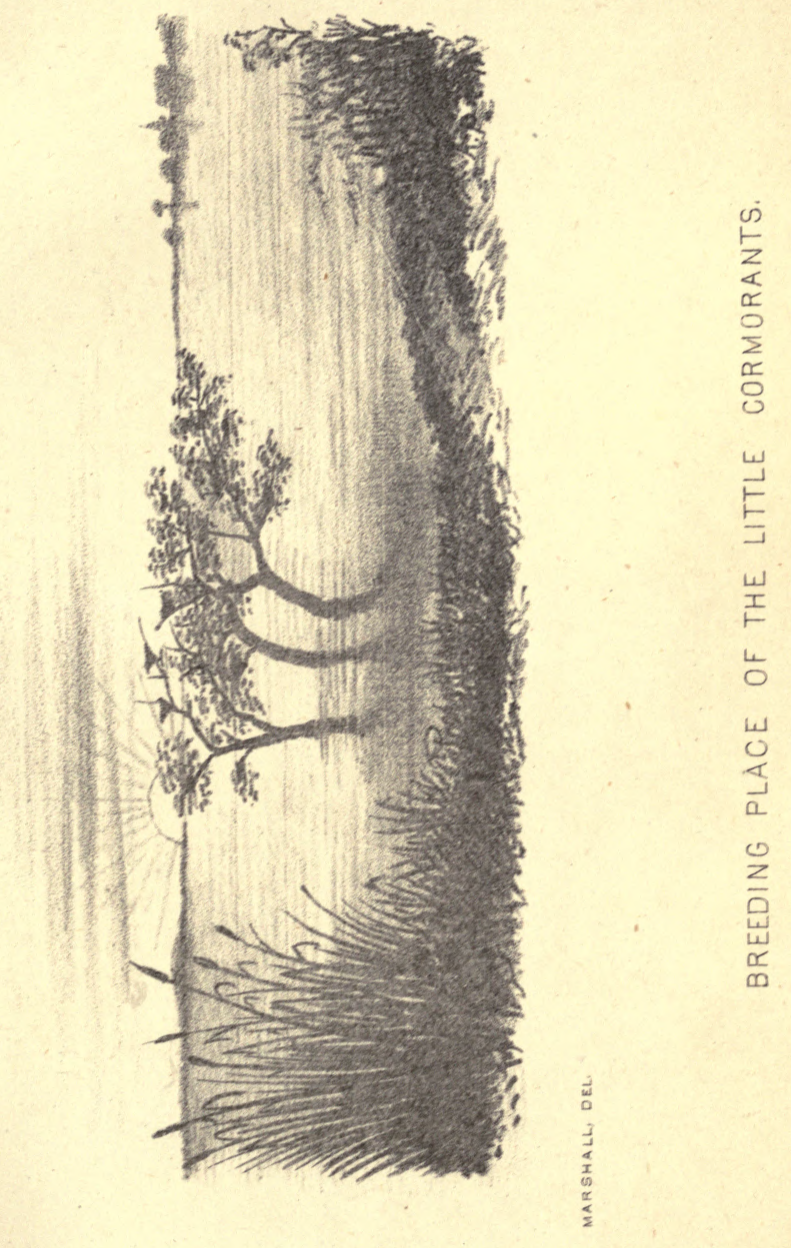




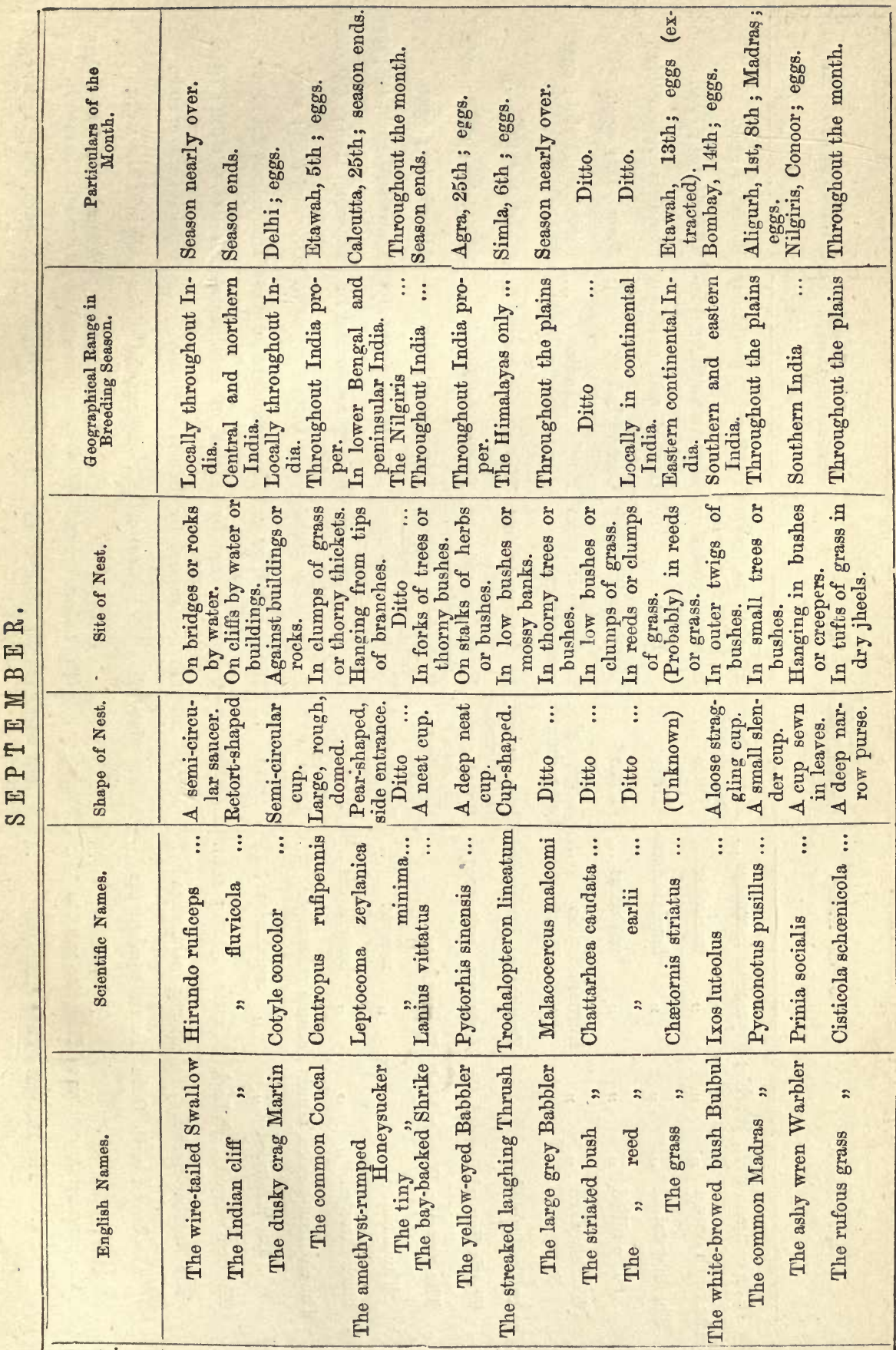

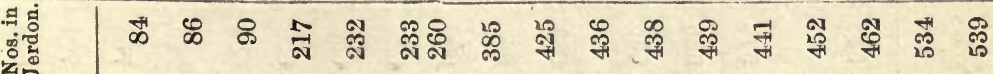




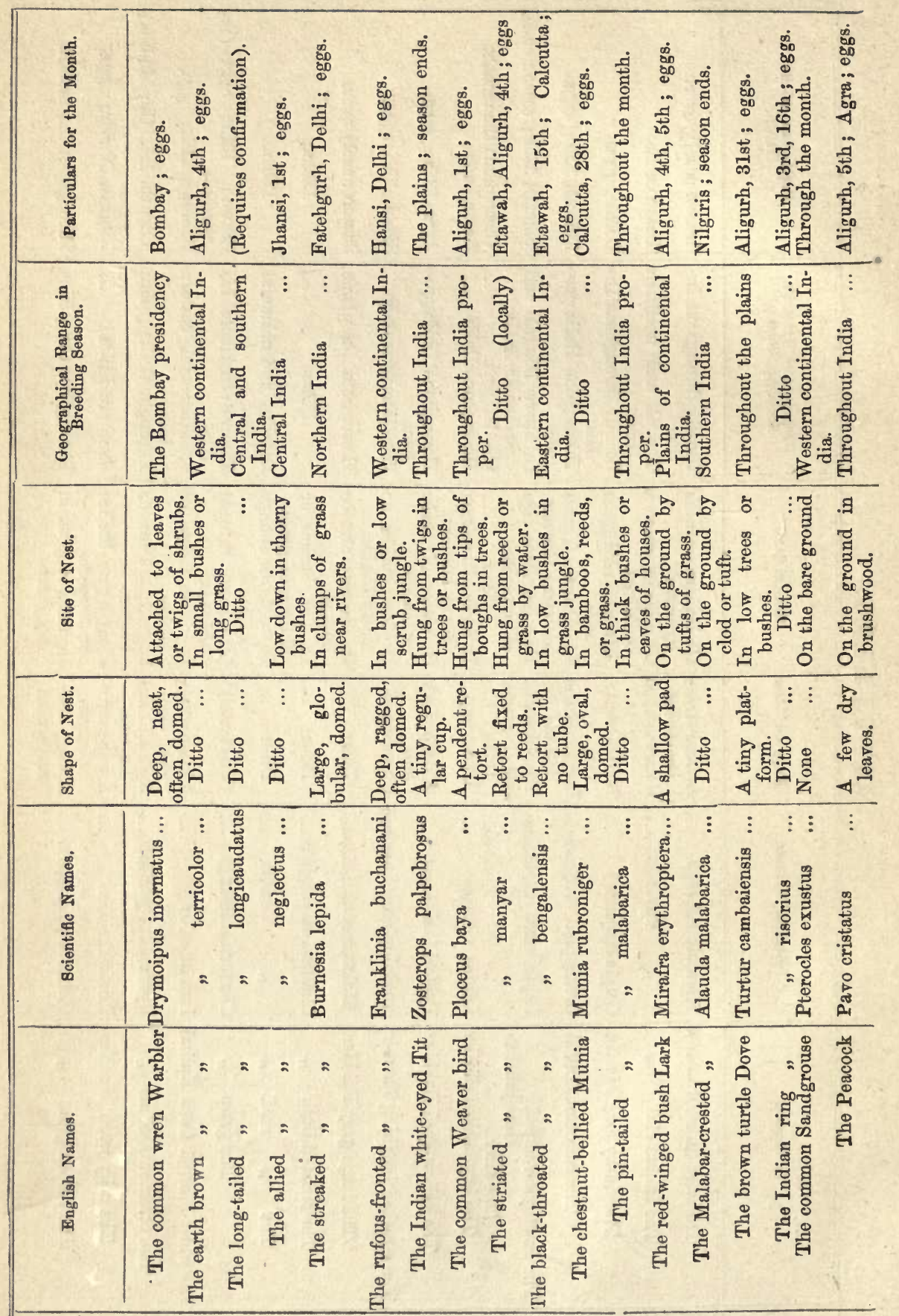

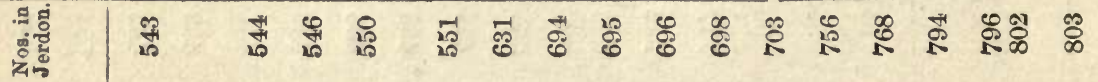




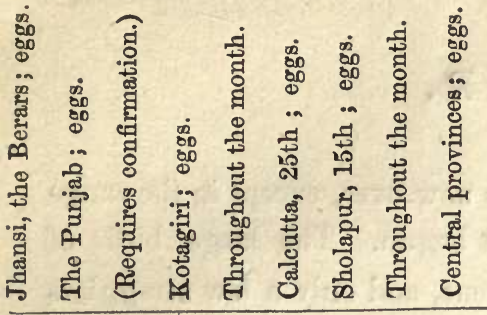

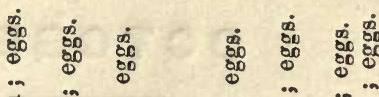

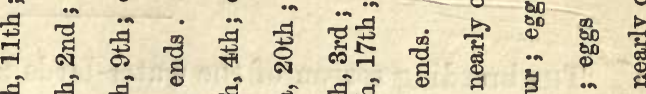

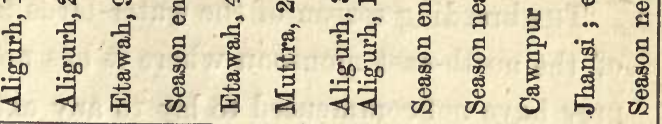

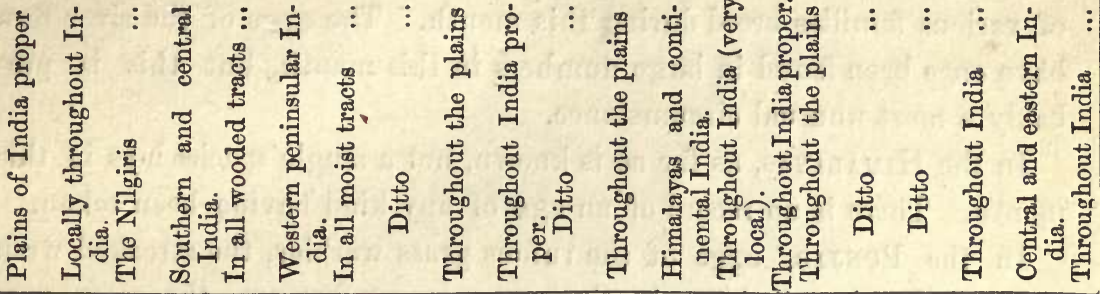

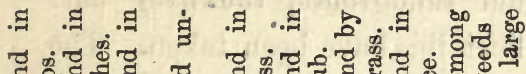
它

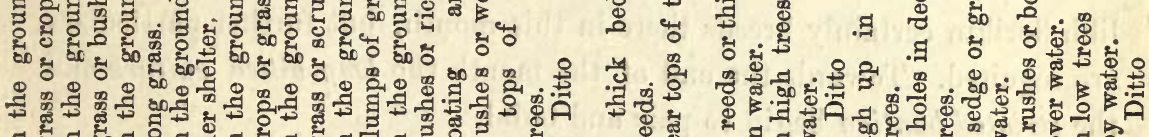

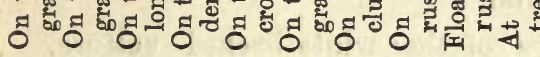

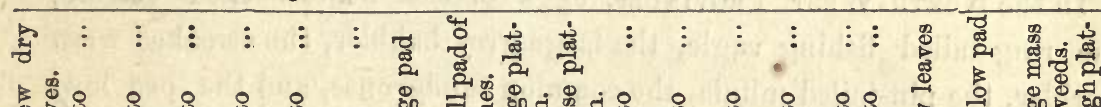

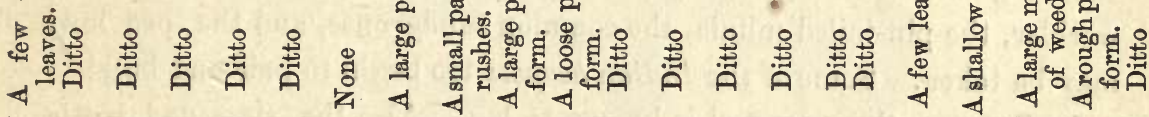

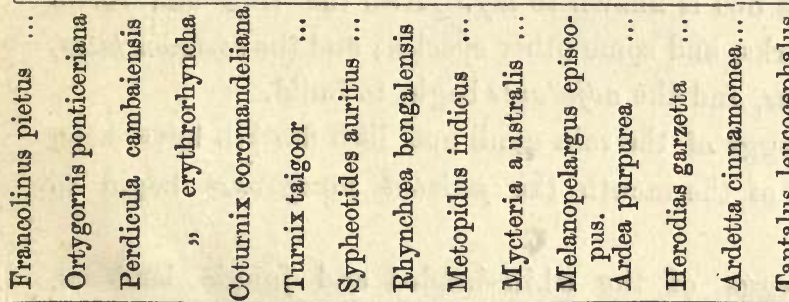

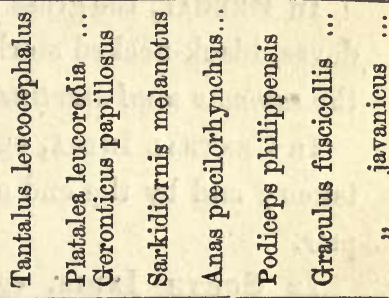

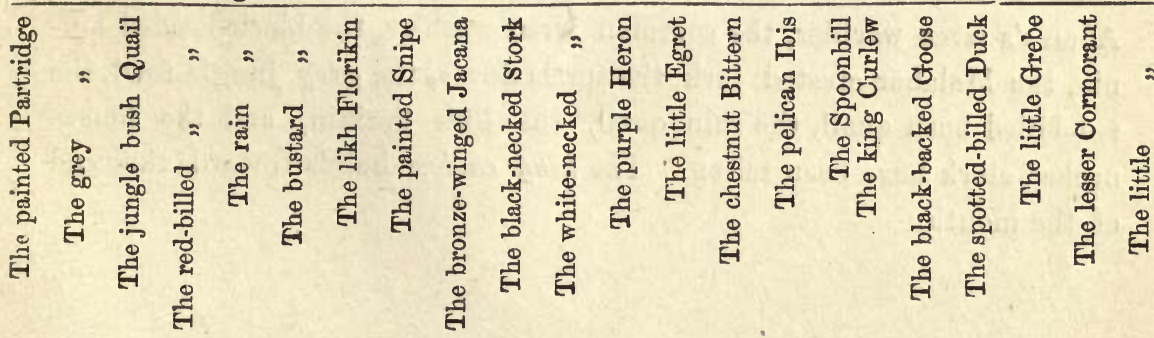

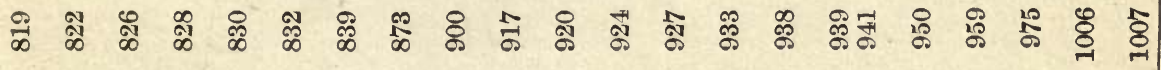




\section{OCTOBER.}

THe breeding season of the water-birds is now over, except in the range of the north-east monsoon where it has not begun. The large birds of prey have not commenced to lay to any extent, and only a few stragglers of various families breed during this month. The eggs of the river tern have once been found in large numbers in this month, but this is probably a most unusual circumstance.

In the Himalayas, as far as is known, not a single species lays in this month. There is no record of an egg of any kind having been taken.

In the PunJaB, eggs of the rufous grass warbler, the streaked wren warbler, the pin-tailed munia, the common sandgrouse, the grey partridge, the black-necked stork, and the pelican ibis have been taken. The likh florikin certainly breeds there in this month, but further particulars are required. Towards the end of the month the long-billed vulture and the striated bunting begin to pair and build.

In the NorTh-West Provinces, eggs of the white-backed vulture, the ring-tailed fishing, eagle, the large grey babbler, the streaked wren warbler, the pin-tailed munia, the common sandgrouse, and the pea fowl may be taken. Some of the Indian hoopoes too begin to pair and build.

In Bengal, the grass owl is kuown to lay. Also the ring and turtle doves, black-necked storks, and some other species; and the common kites, the common sand martins, and the adjutants begin to build.

In Central India, eggs of the rain quail and likh florikin have been taken; and by the end of the month the painted sandgrouse begin to pair.

In South India, eggs of the white-headed and jungle babblers, Adams's wren warbler, the common wren warbler, the black-headed munia, the Malabar-crested lark, the turtle doves, the grey jungle fowl, the red-billed bush quail, the rain quail, the likh florikin, and the blacknecked stork have been taken. The king curlew builds towards the end of the month. 


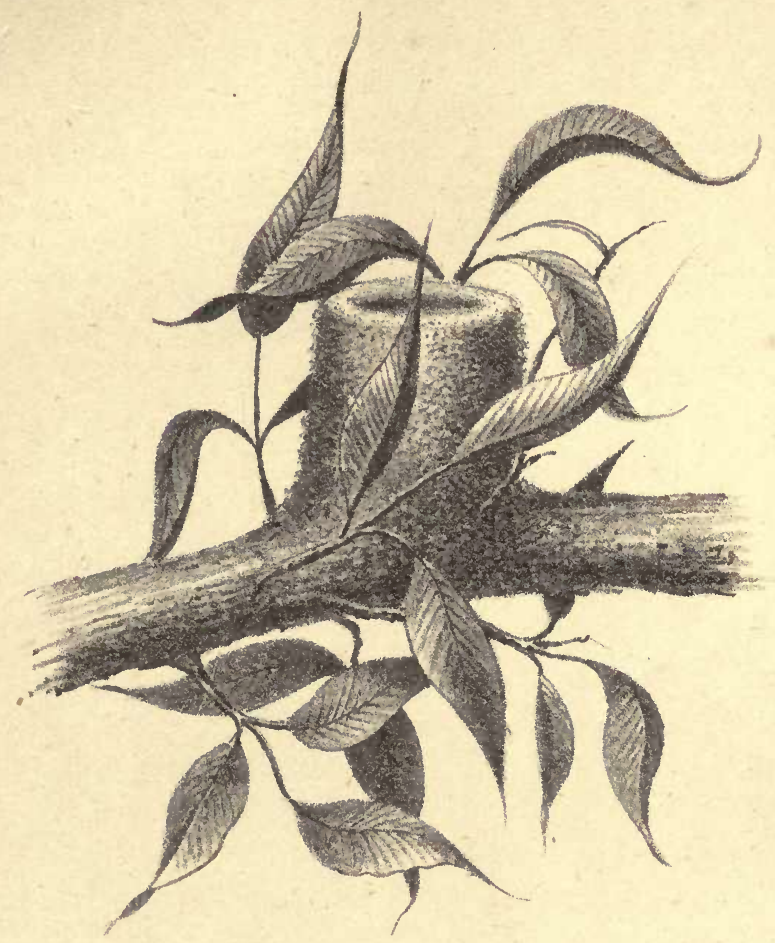

MARSHALL, DEL.

NEST OF THE YELLOW-BELLIED FANTAIL,

(Chetidorhyno hypoxantha.) 



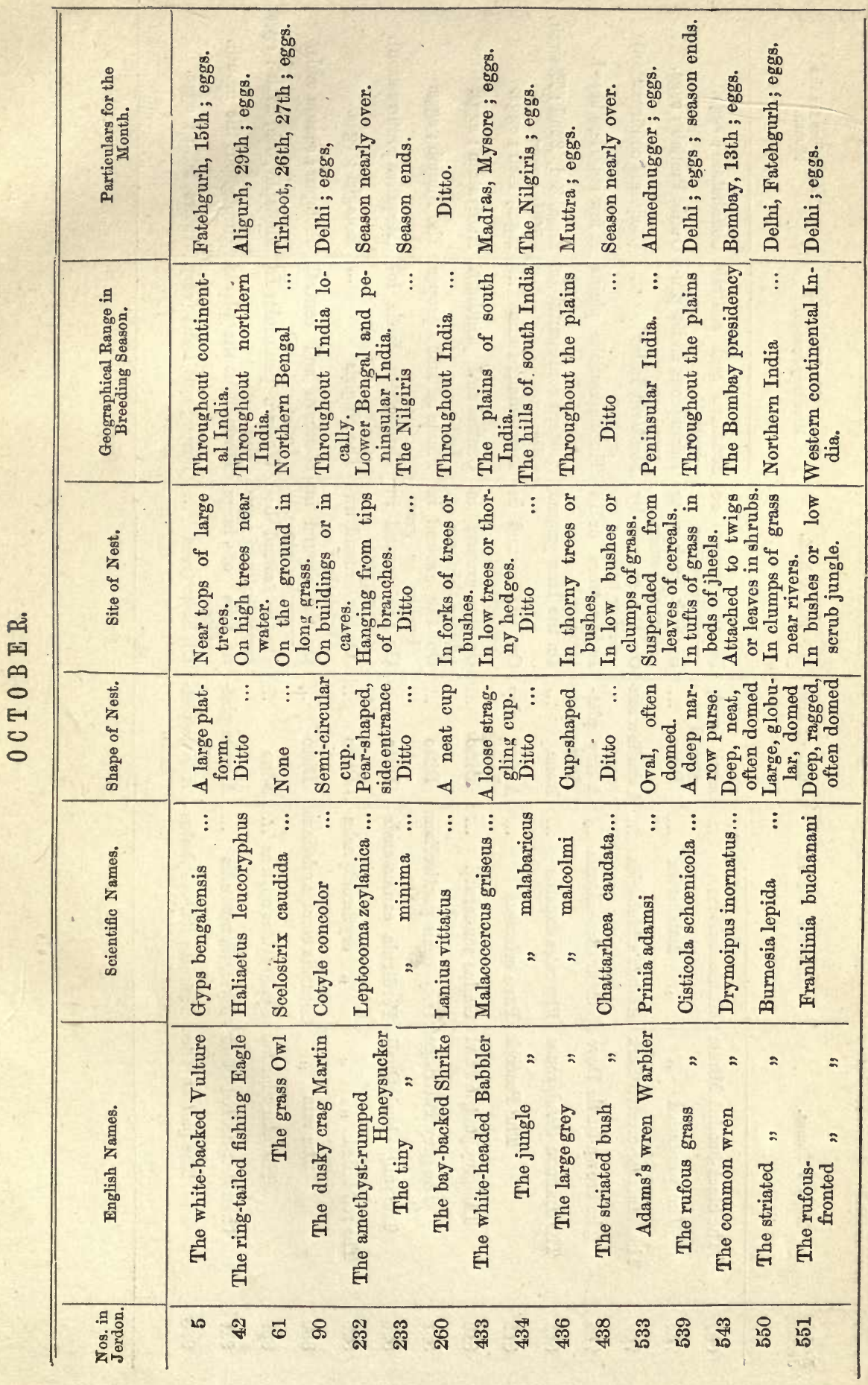




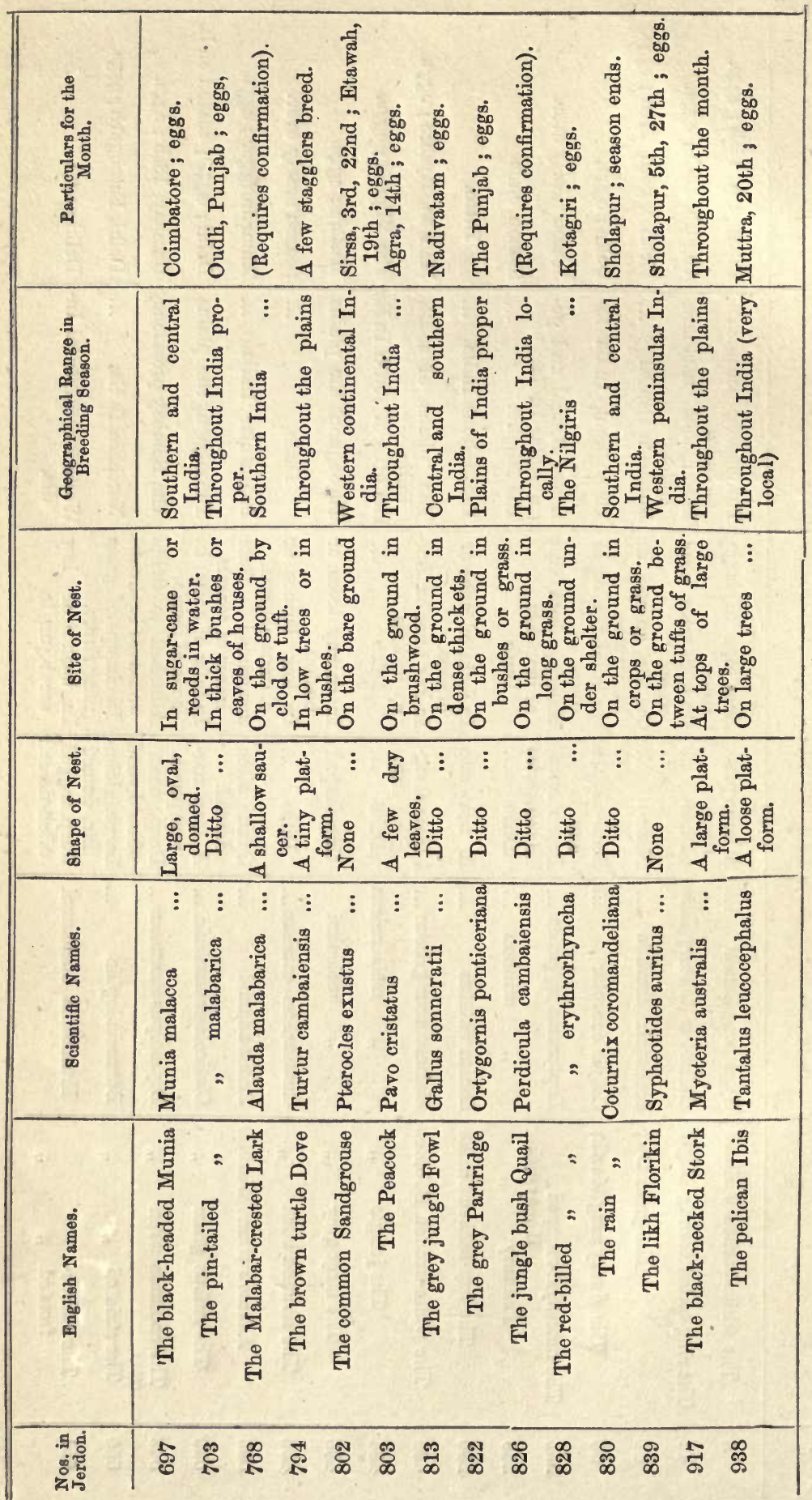





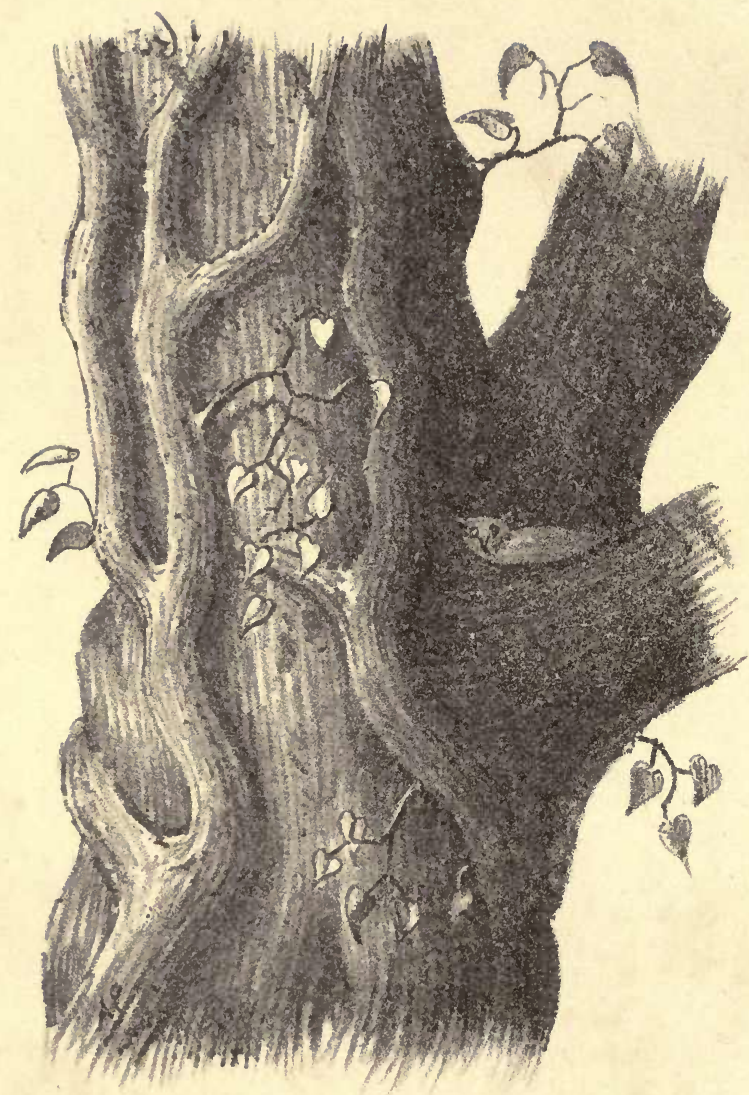

MARSHALL, DEL

NEST OF THE BROWN FISH OWL.

Ketupa ceylonensis.) 


\section{NOVEMBER.}

Ir this month the breeding season is at its lowest ebb. The larger birds of prey are commencing to pair and build, but few of them lay so early. The breeding of the water-birds is almost completely over, and it is only here and there that in particular localities some few species may be found breeding.

In the Himalayas, the bearded vulture, and possibly also the roc vulture, commence to build, but no eggs of any species have been recorded as taken.

In the PunJab, the striated bunting, the common sandgrouse, and the grey partridge have eggs, while the raven begins to build at the latter end of the month.

In the North-West Provinces, eggs of the white-backed vulture, the ring-tailed fishing eagle, the rock-horned owl, the pin-tailed munia, and the black-necked stork may be found, while Bonelli's eagle and the dusky-horned owl are pairing and building; the latter is, more strictly speaking, selecting than building, for it usually occupies an old kite's or eagle's nest.

In BeNGaL, eggs of the grass owl, the common sand martin, and the adjutant, may be found, and possibly some few others, but only these are recorded.

In Central India, the Indian tawny eagle, the black-winged kite, the Indian screech owl, the mottled wood owl, and the painted sandgrouse are all laying. The green amadavat and Sykes' turtle dove are pairing and building.

In SoUTHERN INDIA, eggs of the amethyst-rumped honeysucker, the jungle babbler, the Indian amadavat, the grey jungle fowl, and the king curlew have been taken; and by the end of the month the golden-backed woodpecker, the white-necked stork, and all kinds of egrets have begun to pair and build. 


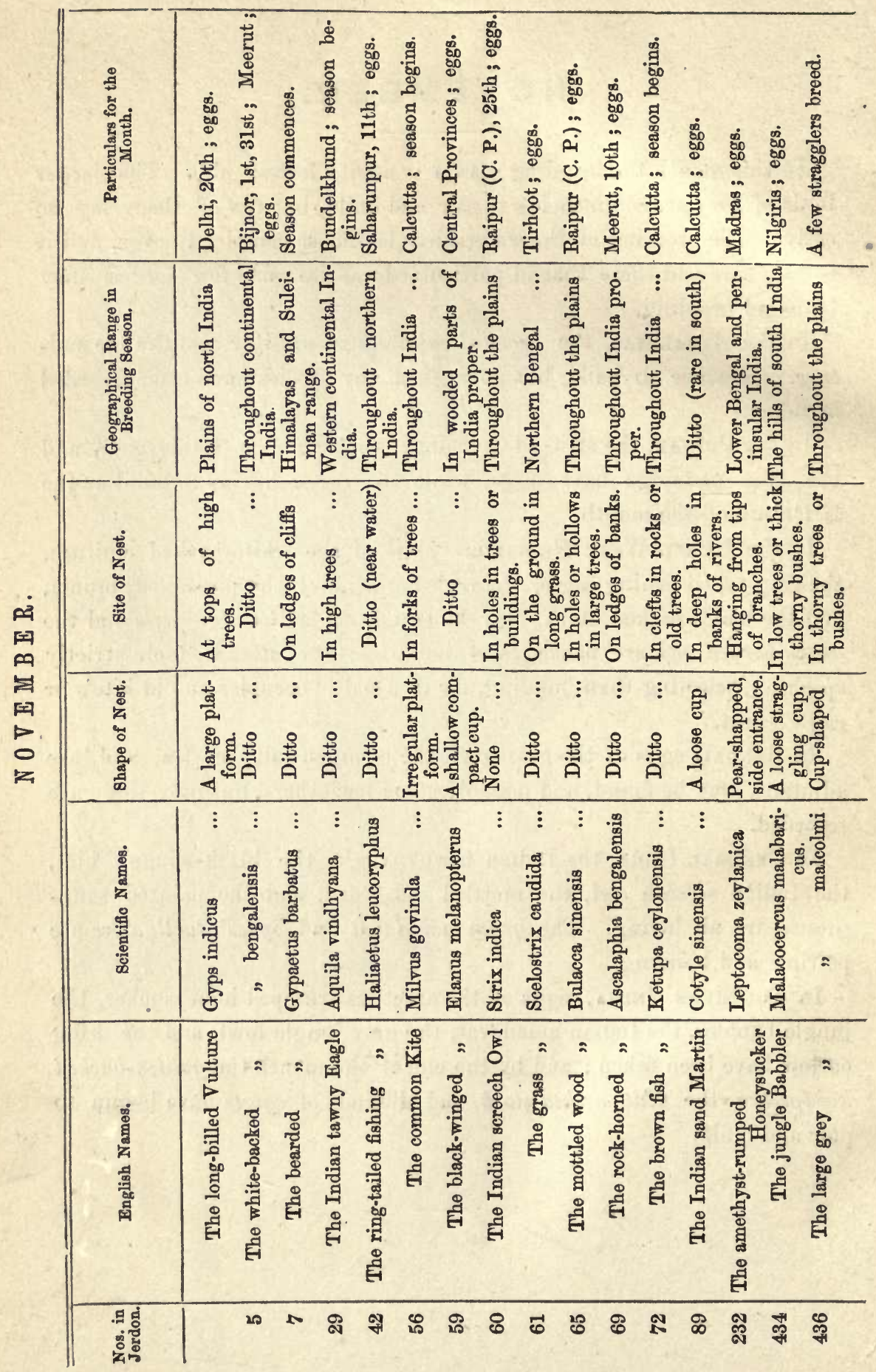




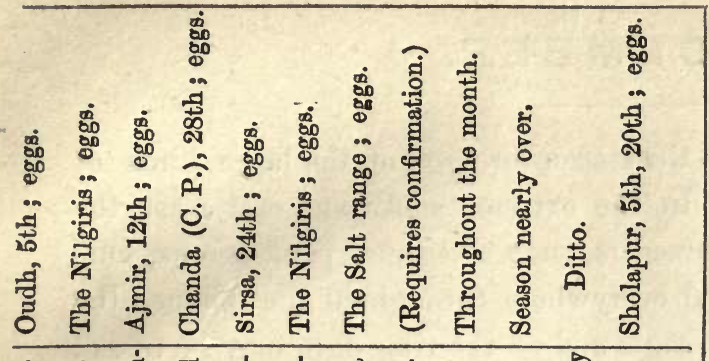

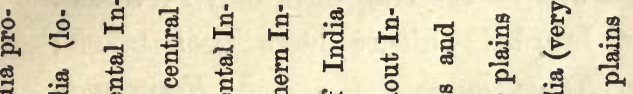

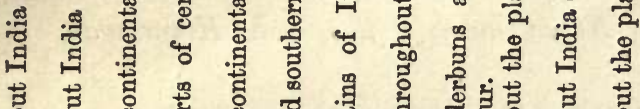

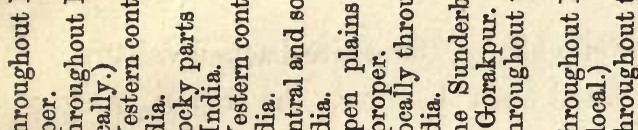

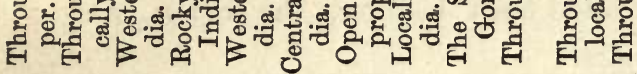

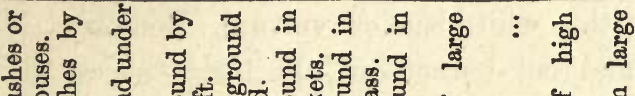

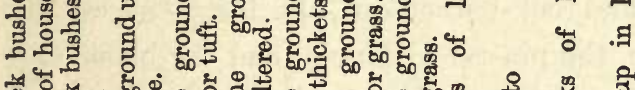
要

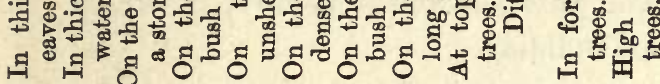

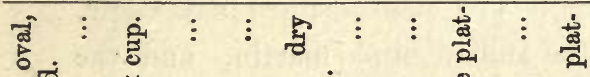

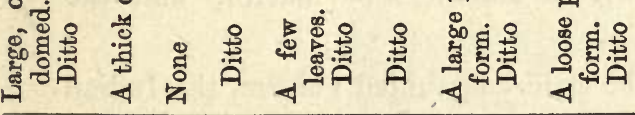

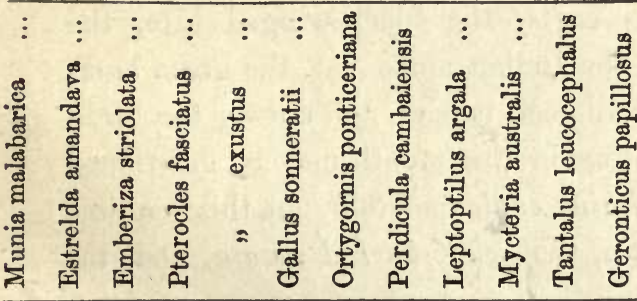

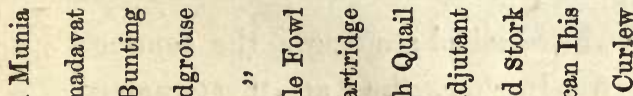

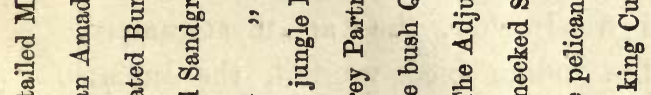

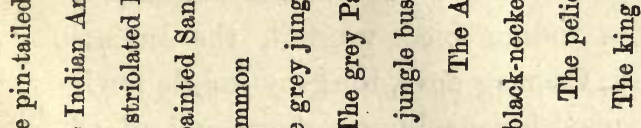

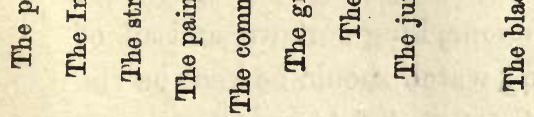

吅莒 \& \& 


\section{DE C E M BER.}

By this time in Upper India the season for eggs of the large birds of prey has fairly commenced. In the extreme south and east coast, the water-birds that are monsoon breeders, such as egrets, pond berons, curlews, \&c., are all breeding; and everywhere throughout the plains, the eggs of the ring-tailed fishing eagle and of the ring dove may be taken.

In the Himalayas, eggs of the bearded vulture have been taken; while the roc vultures, black eagles, Nepal hawk eagles, and Himalayan fishing eagles are all building.

In the PunJaB, the pale long-billed vulture, the white-backed vulture, the ring-tailed fishing eagle, the striated bush babbler, the raven, and the common sandgrouse all have eggs.

In the North-West Provinces, the white-backed vulture, Bonelli's eagle, the ring-tailed fishing eagle and rock-horned owl, the dusky-horned owl, the brown fish owl, the hoopoe, the pin-tailed munia, and the blacknecked stork have all got eggs. The pale long-billed vulture, the dusky sand martin, and the turtle dones are building.

In BENGaL, the ring-tailed fishing eagle and white-bellied sea eagle, the common kite, the brown fish owl, the Indian sand martin, and the ring doves have all got eggs.

In Centrar India, eggs of the pale long-billed vulture, the Indian tawny eagle, the ring-tailed fishing eagle, the black-winged kite, the screech owl, the mottled wood owl, the Indian amadavat, the green amadavat, and Sykes's turtle dove have all been taken; and among the birds that commence pairing and building in this month may be mentioned the shaheen falcon, the bar-tailed fishing eagle (possibly, but this requires confirmation), the dusky crag martin, the white-backed munia, and the ruddy turtle dove.

In Southern India, eggs of the white-bellied sea eagle, the common kite, the southern golden-backed woodpecker, the amethyst-rumped honeysucker, the jungle babbler, the Indian pied wagtail, the Indian amadavat, the black-bellied finch lark, the ring dove, the grey jungle fowl, the white-necked stork, the egrets, pond herons, king curlews, and all of the resident water-birds may be taken; and watch should be kept on the white scavenger vultures, shaheen falcons, bar-tailed fishing eagles, purple honeysuckers, Nilgiri flowerpeckers, red-billed bush quail, and Indian snake birds, which are known to commence building in the course of the month. 


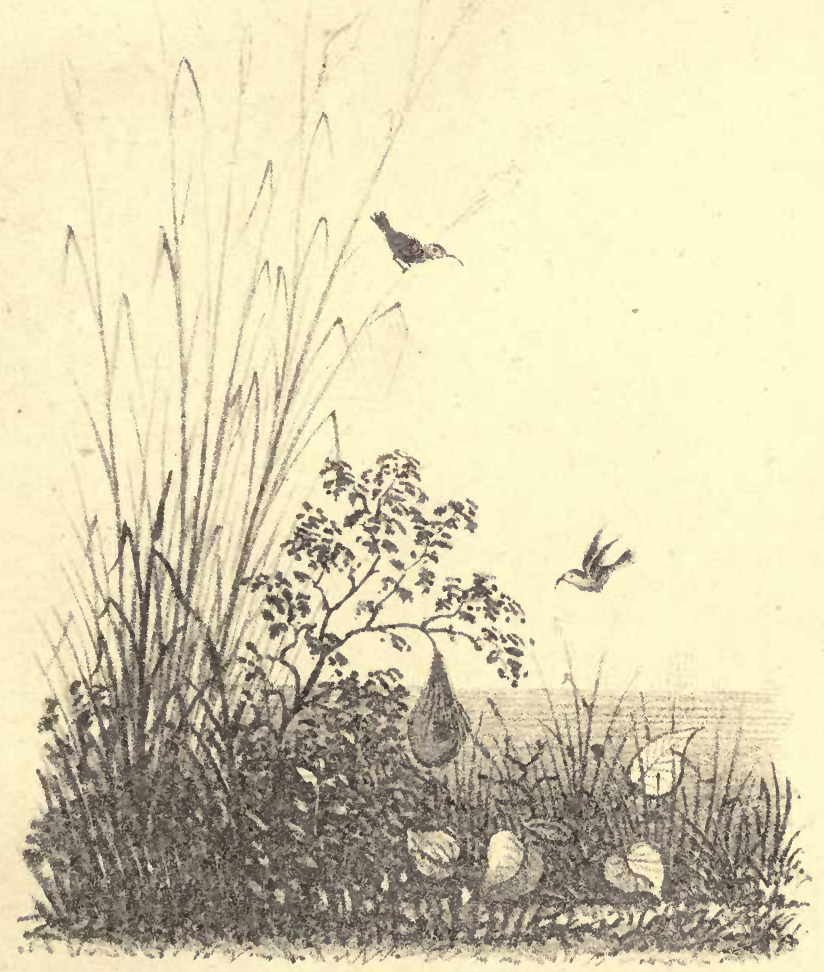

MARSHALL, DEL,

NEST OF THE PURPLE HONEY SUCKER,

(Arachnechthra asiatica.) 



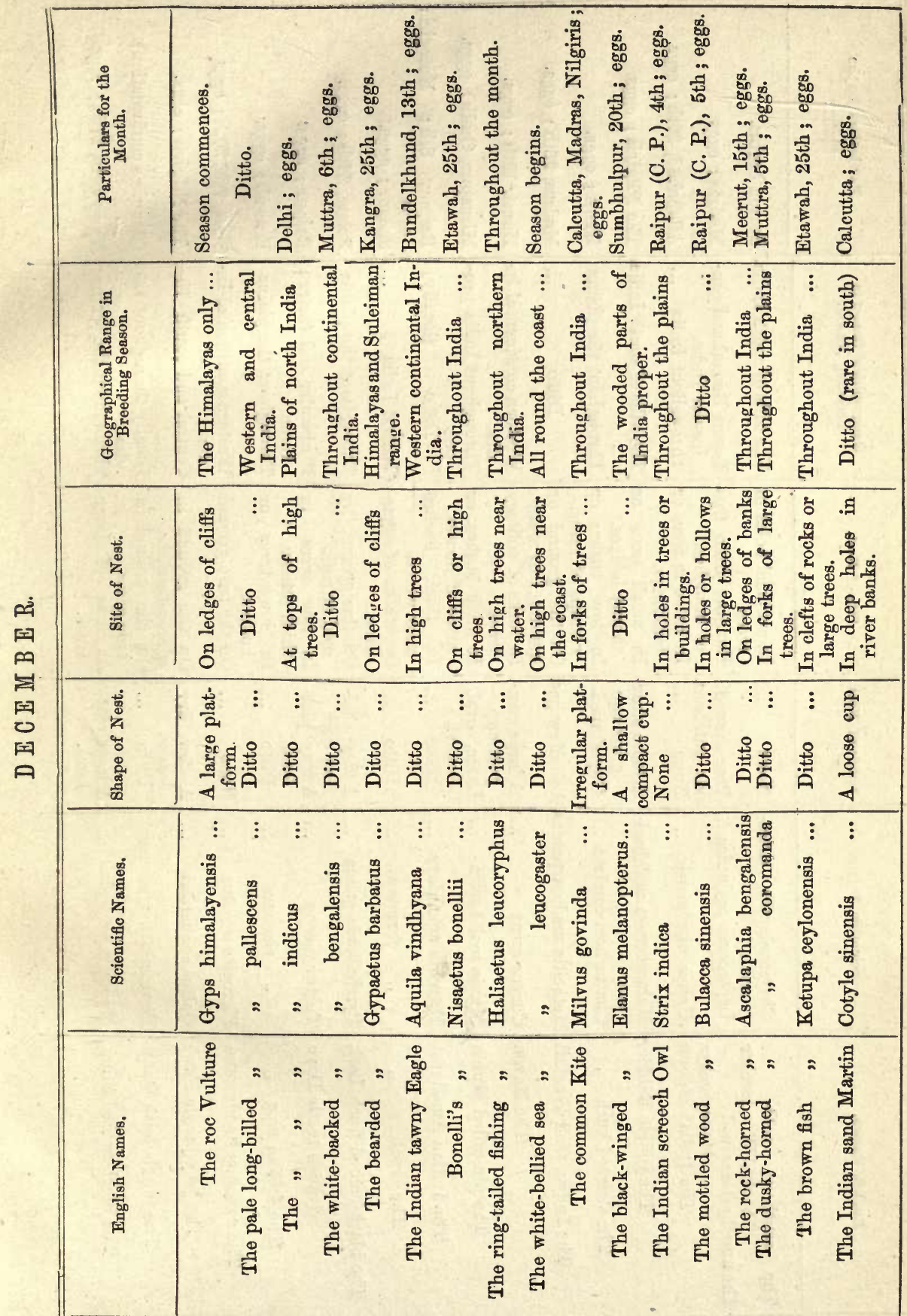

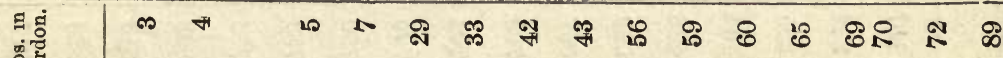
) 


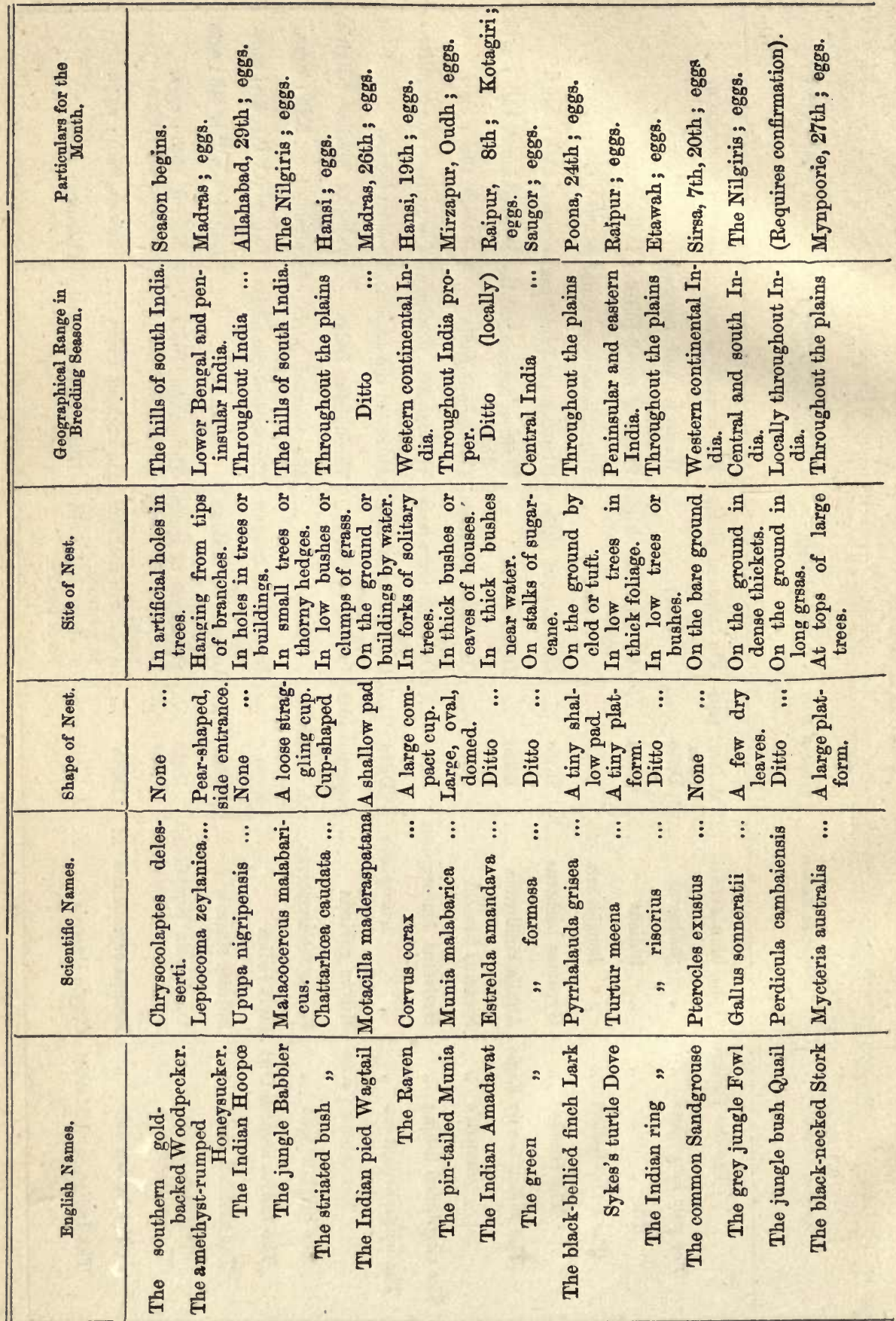

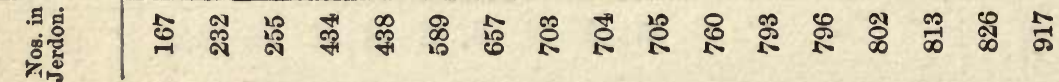




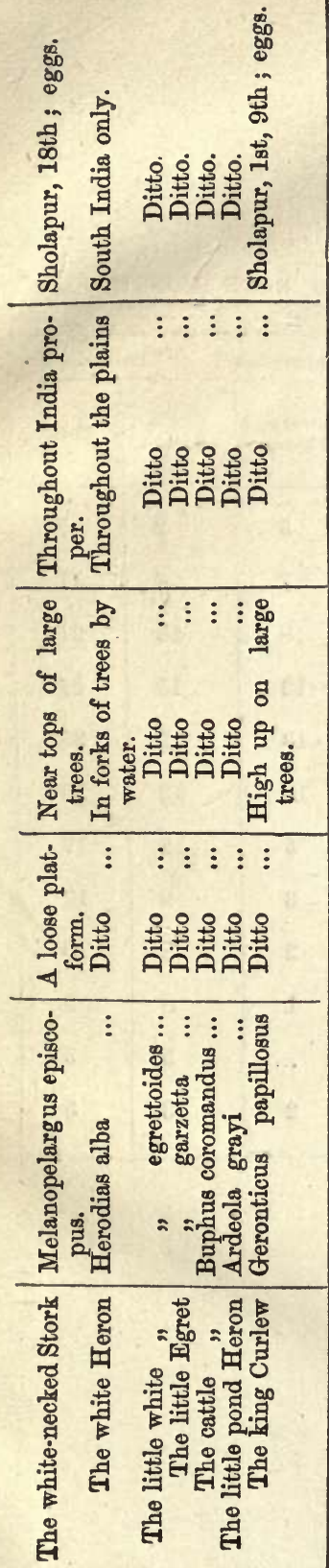

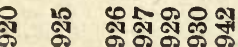




\section{ABSTRACT}

SHOWING NUMBER OF SPECIES KNOWN TO BUILD IN EACH MONTH.

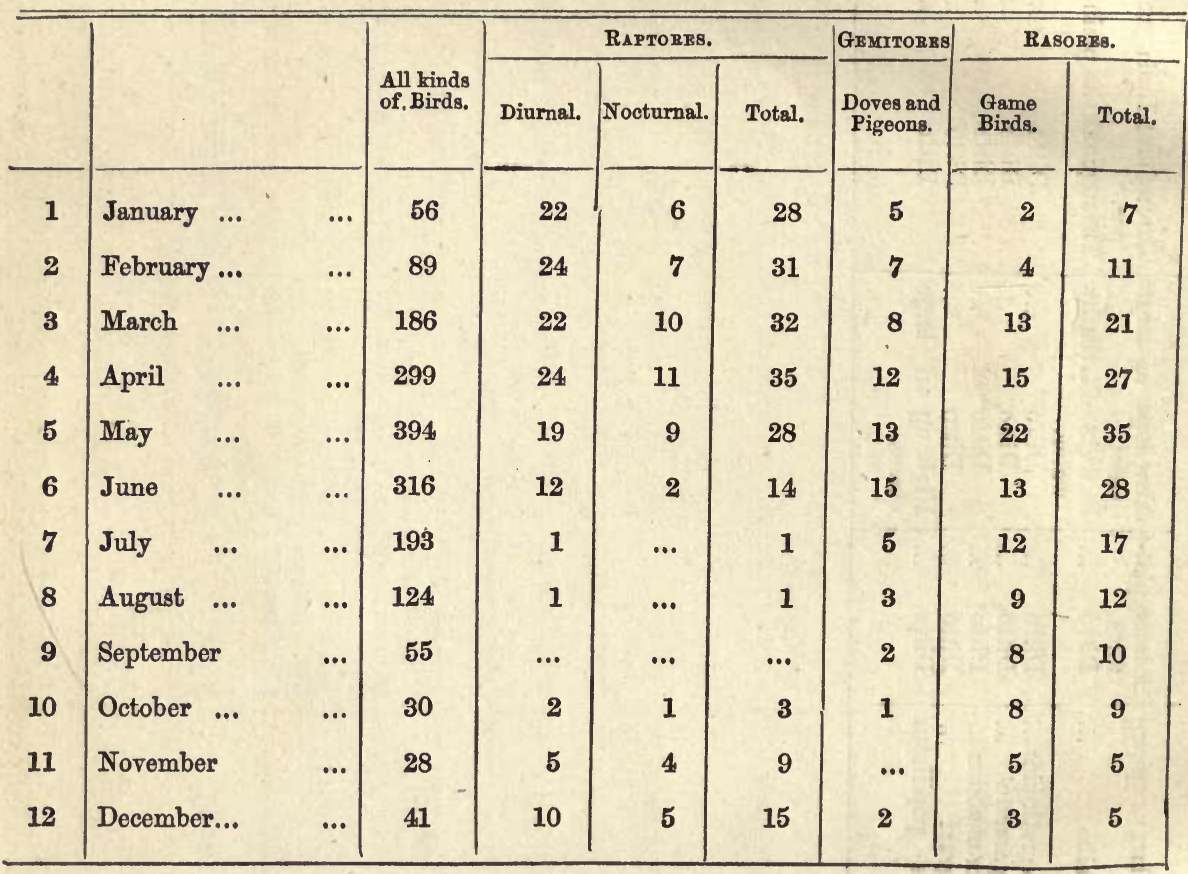





\section{DAY USE}

RETURN TO DESK FROM WHICH BORROWED

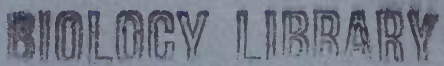

This book is due on the last date stamped below, or on the date to which renewed.

Renewed books are subject to immediate recall.

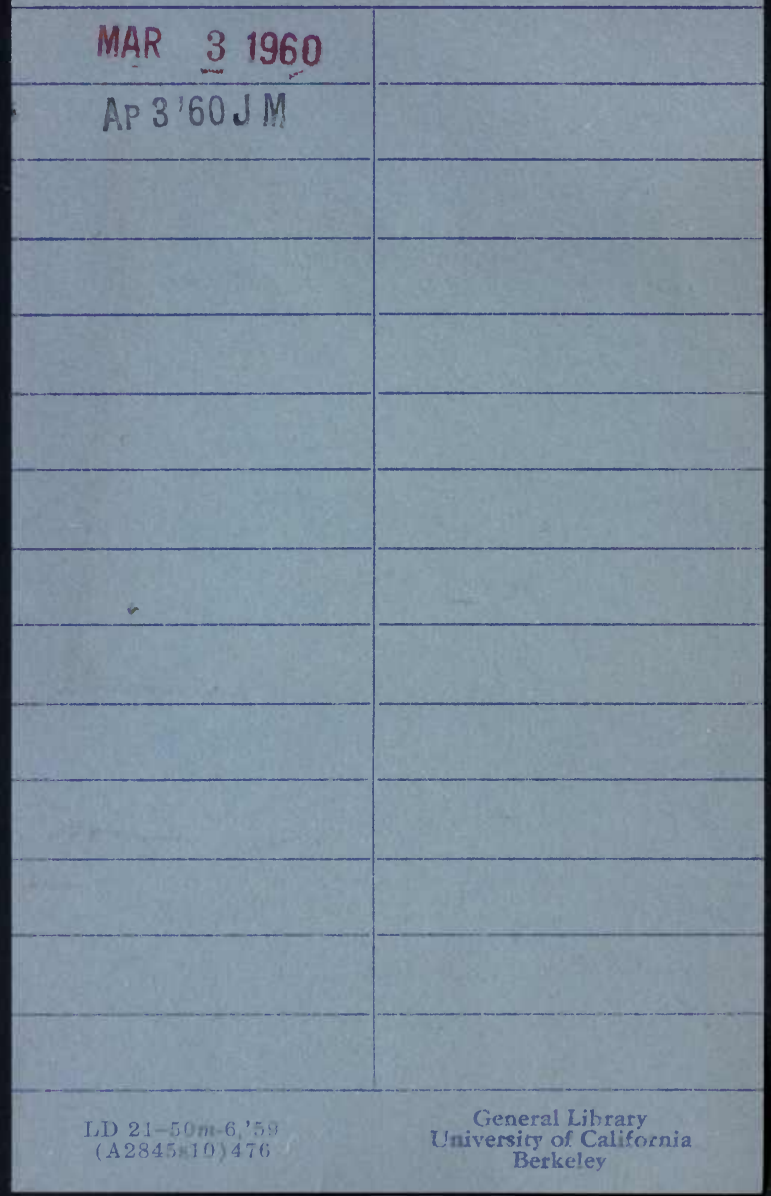




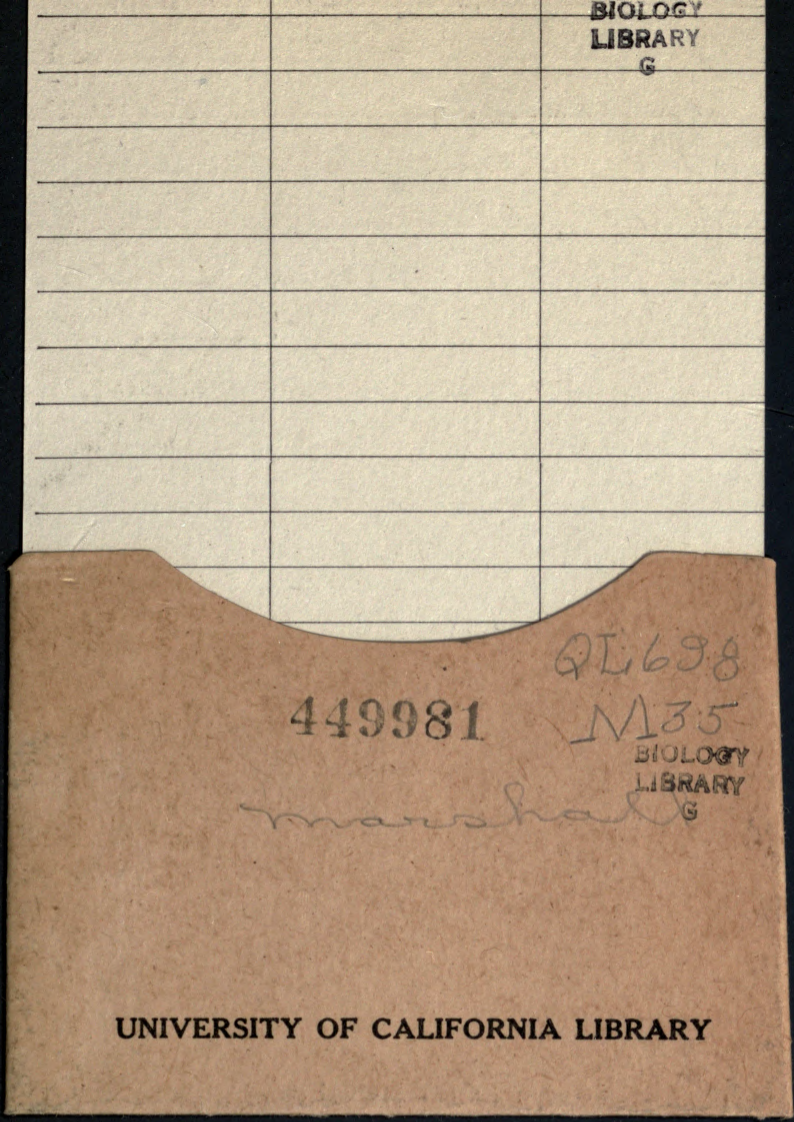


